UNIVERSIDADE DE SALAMANCA

PROGRAMA DE DOUTORADO PASADO Y PRESENTE DE LOS DERECHOS HUMANOS

DEPARTAMENTO DE DIREITO DO TRABALHO E TRABALHO SOCIAL DA FACULDADE DE DIREITO

JULIANE HARTEMINK CANTINI

OS DIREITOS FUNDAMENTAIS E A DIGNIDADE DO TRABALHADOR: AS AÇÕES PREVENTIVAS DOS RISCOS LABORAIS POR ASSÉDIO E VIOLÊNCIA NO AMBIENTE DE TRABALHO.

Salamanca (ES), junho de 2010 


\title{
OS DIREITOS FUNDAMENTAIS E A DIGNIDADE DO TRABALHADOR: AS AÇÕES PREVENTIVAS DOS RISCOS LABORAIS POR ASSÉDIO E VIOLÊNCIA NO AMBIENTE DE
} TRABALHO.

\begin{abstract}
Tese apresentada no Departamento de Direito do Trabalho e Trabalho Social da Faculdade de Direito da Universidade de Salamanca (USAL), na Espanha, orientada pelos Professores Doutores Enrique Cabero Morán e Pilar Jiménez Tello. O trabalho é condição para a obtenção do título de Doutora pela Universidade de Salamanca.
\end{abstract}




\title{
OS DIREITOS FUNDAMENTAIS E A DIGNIDADE DO TRABALHADOR: AS AÇÕES PREVENTIVAS DOS RISCOS LABORAIS POR ASSÉDIO E VIOLÊNCIA NO AMBIENTE DE TRABALHO.
}

\author{
TESE APRESENTADA PARA A OBTENÇÃO DO TÍTULO DE DOUTORA PELA \\ UNIVERSIDADE DE SALAMANCA
}

Prof. Dr. Enrique Cabero Morán Diretor da Tese

Prof ${ }^{a}$. Dra. Pilar Jiménez Tello Diretora da Tese 


\section{OS DIREITOS FUNDAMENTAIS E A DIGNIDADE DO TRABALHADOR: AS AÇÕES PREVENTIVAS DOS RISCOS LABORAIS POR ASSÉDIO E VIOLÊNCIA NO AMBIENTE DE TRABALHO.}

Programa de Doutorado Pasado y Presente de los Derechos Humanos Departamento de Derecho del Trabajo y Trabajo Social

Orientadores: Prof. Dr. Enrique Cabero Morán e Prof ${ }^{a}$. Dra Pilar Jiménez Tello

Doutoranda: Juliane Hartemink Cantini

CT 514360

Endereço: Avenida de Portugal, $148,1^{\circ} \mathrm{D}$

Barrio Vidal - Salamanca - Salamanca

Código Postal: 37006 - Espanha

Correo electrónico: juliacantini@ @yahoo.com.br 


\section{DEDICATÓRIA}

Para minha mãe Noemia, pela inesgotável compreensão. 


\section{AGRADECIMENTOS}

Ao Prof. Dr. Enrique Cabero Morán por acreditar que a Pedagogia tem estreita ligação com o Direito do Trabalho e pela autonomia que me foi dada para desenvolver essa pesquisa.

À Prof ${ }^{a}$ Dra Pilar Jiménez Tello, pela referência profissional, dedicação e recomendações sempre acertadas.

À minha irmã e amiga Adriana Hartemink Cantini, porque sem ela dificilmente conseguiria avançar.

À minha irmã Cibele Cantini Espíndola, que apesar da distância esteve sempre presente.

Ao meu cunhado e amigo Fancisco Célio de Souza, que sempre me apoiou e motivou.

À Márcio de Andrade Zago, pela ajuda na redação e compreensão da língua espanhola.

À Ricardo dos Santos Bezerra, colega de curso, pelas discussões e elucubrações acadêmicas.

Ao Dr. Francisco Donino da Costa Lima, pelas nossas conversas a respeito das enfermidades laborais e suas conseqüências.

Ao Sindicato dos Bancários de Pernambuco, em especial, a João Rufino.

À Elda Madruga do Banco do Brasil (GEPES/Recife) pela gentileza e informações prestadas. 


\section{RESUMO}

O objeto do presente estudo é enfocar as ações preventivas para inibir a violência e o assédio no ambiente de trabalho. Inicialmente faremos um breve histórico sobre os Documentos internacionais de proteção a pessoa. $\mathrm{Na}$ ordem jurídica internacional, destacamos as Recomendações e Convenções da Organização Internacional do Trabalho (OIT) e a Declaração Sóciolaboral do Mercosul. Já no âmbito Europeu, citamos as Diretivas relativas ao princípio de igualdade no tratamento de homens e mulheres e a não discriminação no emprego. Destacamos as Constituições do Brasil e da Espanha, enfocando os direitos fundamentais do trabalhador e como estão positivados na legislação de ambos os países. Nesse sentido, estudamos as enfermidades que o trabalhador está sujeito em um ambiente de trabalho hostil e conflituoso, como o estresse e o burnout, a violência psicológica, que podem desencadear diferentes tipos de assédio no lugar de trabalho: o assédio moral, o assédio sexual e o assédio por razão de sexo. Enfatizamos a gestão empresarial, destacando os Códigos de Conduta e Ética das empresas e o que eles nos revelam em matéria de responsabilidade social e de proteção dos direitos fundamentais no trabalho. Para tanto, trouxemos as Diretrizes para as Empresas Multinacionais da Organização para o Desenvolvimento Econômico (OCDE), a Declaração Tripartite de Princípios para as Empresas Multinacionais e a Política Social da OIT e o Pacto Global, uma iniciativa voluntária das Nações Unidas que mobiliza a comunidade empresarial a adotar práticas comerciais através de valores fundamentais na área de Direitos Humanos, traduzidos em dez princípios. Ainda, no que concerne a responsabilidade social empresarial, trouxemos as normas de Direitos Humanos para as Empresas também das Nações Unidas, contendo uma lista de obrigações empresariais sobre de Direitos Humanos. Dentro desse tema, citamos as iniciativas da sociedade civil sobre responsabilidade social e sustentabilidade corporativa, expressas através de Normas e Diretrizes. E, ao final, trabalhamos as ações preventivas para inibir os riscos laborais por assédio e violência no ambiente de trabalho, destacando a origem da avaliação e a importância de se estabelecer uma avaliação em Direitos Humanos como instrumento de gestão e controle da atividade administrativa empresarial, discutindo também, o papel dos sindicatos nesta tarefa. 
Palavras Chave: Direitos Humanos, Enfermidades Laborais, Assédio, Gestão Empresarial, Ações Preventivas. 


\section{RESUMEN}

El objeto de este estudio es centrarse en las acciones preventivas para inhibir la violencia y el acoso en el lugar de trabajo. Inicialmente haremos un breve recorrido histórico sobre los Documentos internacionales de protección de la persona. En la orden jurídica internacional, hacemos hincapié las Recomendaciones y Convenciones de la Organización Internacional del Trabajo (OIT) y de la Declaración Sociolaboral del Mercosur. En el ámbito Europeo, citamos las Directivas relativas al principio de igualdad de trato entre hombres y mujeres y la no discriminación en el empleo. Destacamos las Constituciones de Brasil y España, centrándose en los derechos fundamentales de los trabajadores y cómo se positiva en la legislación de ambos países. En consecuencia, se ha estudiado acerca de las enfermedades que el trabajador está sometido en un ambiente de trabajo hostil y pesado, como el estrés, el burnout y la violencia psicológica, que puede desencadenar diferentes tipos de acoso en el lugar de trabajo: el acoso moral, el acoso sexual y el acoso por razón de sexo. Subrayamos la gestión empresarial, destacando los Códigos de Conducta y Ética de las empresas y lo que revelan sobre la responsabilidad social y la protección de los derechos fundamentales en el trabajo. Con este fin, hemos traído las Directrices para Empresas Multinacionales de la Organización para el Desarrollo Económico (OCDE), la Declaración Tripartita de Principios sobre las Empresas Multinacionales y la Política Social de la OIT y el Pacto Mundial, una iniciativa voluntaria de las Naciones Unidas para movilizar la comunidad empresarial a adoptar prácticas comerciales a través de valores fundamentales en materia de Derechos Humanos, traducidos en diez principios. Incluso con respecto a la responsabilidad social corporativa, subrayamos las normas de Derechos Humanos para las Empresas también de Naciones Unidas, que contienen una lista de obligaciones empresariales sobre Derechos Humanos. A este respecto, citamos las iniciativas de la sociedad civil sobre responsabilidad social corporativa y sostenibilidad, expresadas a través de Normas y Directrices. Y, por último, trabajamos las acciones preventivas para inhibir los riesgos laborales por acoso y violencia en el lugar de trabajo, destacando el origen de la evaluación y la importancia de establecer una evaluación de Derechos Humanos como una herramienta para la gestión y el control 
administrativo de la actividad empresarial y discutimos el papel de los sindicatos en esta tarea.

Palabras Claves: Derechos Humanos, Enfermedades Laborales, Acoso, Gestión Empresarial, Acciones Preventivas. 


\section{ÍNDICE DE ABREVIATURAS UTILIZADAS}

ASEPAM Associação Espanhola do Pacto Mundial

CBPG Comitê Brasileiro do Pacto Global

CC Código Civil

CF Constituição Federal

CIOSL Confederación Sindical Internacional

CIPA Comissão Interna de Prevenção de Acidentes

CLT Consolidação das Leis do Trabalho

COP Comunicação de Progresso do Pacto Global

CPC Código de Processo Civil

EFQM Modelo Europeu de Gestão de Qualidade

EPI Equipamento de Proteção Individual

ET Estatuto de los Trabajadores

EU União Européia

GRI Global Reporting Initiative

IBASE Instituto Brasileiro de Análises Sociais e Econômicas

INSS Instituto Nacional de Seguridade Social

ISO International Organization for Standardization 
ISTAS Instituto Sindical de Trabajo, Ambiente y Salud

LGS Ley General de Sanidad

LISOS Ley de Infracciones y Sanciones en el Orden Social

LOIMH Ley Orgânica para la Igualdad Efectiva de Mujeres y Hombres

LPRL Ley de Prevención de Riesgos Laborales

MERCOSUL Mercado Comum do Sul

MTE Ministério do Trabalho e Emprego

NR Normas Reguladoras

OCDE organização para Cooperação e Desenvolvimento Econômico

OMS Organização Mundial da Saúde

ONG Organização não-governamental

OIT Organização Internacional do Trabalho

ONU Organização das Nações Unidas

OPRPS Observatorio Permanente de Riesgos Psicosociales

OHSAS Occupational Health \& Safety Advisory Services

OSHA Agencia Europea para la Seguridad y la Salud en el Trabajo

PIDESC Pacto Internacional de Direitos Econômicos, Sociais e Culturais

PIDCP Pacto Internacional de Direitos Civis e Políticos

PNDU Programa das Nações Unidas para o Desenvolvimento

SAI Social Accountability International

SESMT Serviço Especializado em Engenharia de Segurança e Medicina no Trabalho 
TST Tribunal Superior do Trabalho

UGT Unión General de los Trabajadores 


\section{SUMÁRIO}

ÍNDICE DE ABREVIATURAS........................................................... 13

RESUMEN DE LA TESIS EN ESPAÑOL ............................................. 16

INTRODUÇÃ

JUSTIFICATIVA E RELEVÂNCIA DO ESTUDO .............................. 59

METODOLOGIA DA PESQUISA ..................................................... 61

\section{I - O DIREITO À DIGINIDADE DO TRABALHADOR}

1.1. Na Ordem Jurídica Internacional............................................................ 64

1.1.1. Na Organização Internacional do Trabalho (OIT) ………………………... 75

1.1.2. No Mercado Comum do Sul (MERCOSUL) ............................................. 79

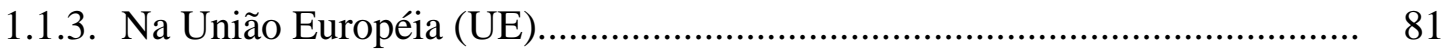

1.2. Os Direitos Fundamentais do Trabalhador na Ordem Jurídica Brasileira .... 85

1.3. Os Direitos Fundamentais do Trabalhador na Ordem Jurídica Espanhola ... 96

1.4. A proteção à Segurança e à Saúde do Trabalhador no Brasil e na Espanha:

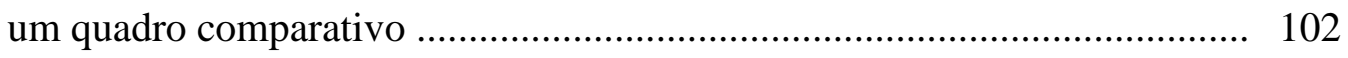

II - OS RISCOS LABORAIS E PSICOSSOCIAIS NO AMBIENTE DO TRABALHO

2.1. As Enfermidades Decorrentes do Ambiente Laboral ................................. 110

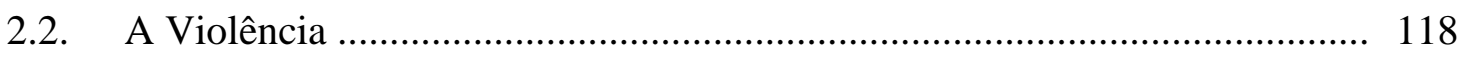

2.2.1. O Assédio Moral .................................................................................. 122

2.2.2. O Assédio Sexual ............................................................................ 136 
2.2.3. O Assédio por Razão de Sexo

2.3. As Consequências da Conduta de Assédio para o Trabalhador e para a Empresa

\section{III - GESTÃO EMPRESARIAL E OS DIRETOS HUMANOS}

3.1. A Ética e os Códigos de Conduta Empresariais ........................................ 148

3.2. Os Direitos Humanos ................................................................................ $\quad 160$

3.2.1. A Responsabilidade Social Empresarial ................................................... 167

3.3. As Diretrizes para as Empresas Multinacionais da Organização para a Cooperação e Desenvolvimento Econômico (OCDE)

3.3.1. A Declaração Tripartite de Princípios sobre Empresas Multinacionais e a Política Social da OIT

3.3.2. O Pacto Global (Global Compact) da Organização das Nações Unidas para as Empresas

3.3.3. As Normas de Direitos Humanos para as Empresas das Nações Unidas ..... 218

3.4. As Iniciativas da Sociedade Civil ...................................................... 233

4. As Ações Preventivas para Inibir o Assédio e as Enfermidades Laborais.... 242

4.1. O Papel dos Sindicatos e dos Órgãos de Proteção ao Trabalhador.............. 273

CONSIDERAÇÕES FINAIS _.................................................... 282

REFERÊNCIAS BIBLIOGRÁFICAS ......................................... 284 
RESUMEN

LOS DERECHOS FUNDAMENTALES Y LA DIGNIDAD DE LOS

TRABAJADORES: LAS ACCIONES PREVENTIVAS DE LOS RIESGOS

LABORALES POR ACOSO Y VIOLENCIA EN EL LUGAR DE TRABAJO.

\section{EL DERECHO A LA DIGNIDAD DEL TRABAJADOR}

\subsection{En el Orden Jurídico Internacional}

En Inglaterra elaboraron las Cartas y los Estatutos de los derechos fundamentales, como la Carta Magna de João Sin Tierra (1215), que reconoce en su texto los derechos fundamentales como la libertad de religión, el juicio popular para los delitos contra la vida, entre otros, la Petition of Rights (1628). Documento elaborado por el Parlamento británico ratificó la Constitución de 1215, llamando la atención a los derechos y libertades ya reconocidos en el documento anterior. Otro documento de igual importancia fue la Bill of Rights - Declaración de los Derechos de la revolución que tuvo lugar en 1688, dando primacía al Parlamento y al fortalecimiento de la monarquía constitucional británica.

En el sentido moderno, la primera Declaración que da a los derechos fundamentales y que, según algunos autores es el registro de nacimiento de los Derechos Humanos en la historia, fue la Declaración del Buen Pueblo de Virginia, que fue una de las colonias británicas de la época (1776). Ella expresó con claridad los fundamentos de la democracia, el reconocimiento de los derechos inherentes de la 
persona humana y el principio de que emana el poder del pueblo. Ya la Declaración de los Derechos del Hombre y del Ciudadano (1789), aprobada en el apogeo de la Revolución Francesa, se centró en los derechos de la libertad y la propiedad. En el siglo XIX, escenario de la Revolución Industrial, Karl Marx escribió el Manifiesto Comunista en 1948, uno de los documentos políticos más importantes de la crítica socialista al régimen liberal burgués, lo que sugiere un curso de acción para una revolución socialista a través de la toma del poder por el proletariado. En este momento, otro documento fue publicado por la Iglesia Católica, la Encíclica Papal Rerum Novarum, escrita por el Papa León XIII (1891). El Documento criticó las condiciones de vida de los trabajadores y apoyaba el reconocimiento de los derechos laborales mediante el establecimiento de algunas condiciones míninas de protección a los trabajadores. La Constitución Mexicana (1917) y la Constitución Alemana de Weimar (1919) fueron las pioneras en positivar los derechos económicos, sociales y culturales. Otros Documentos que también importantes son el Pacto Internacional de Derechos Civiles y Políticos (PIDCP) y el Pacto Internacional de Derechos Económicos, Sociales y Culturales (PIDESC), ambos aprobados por la Asamblea General de la ONU en 1966. Los Pactos tratan del trabajo forzoso, la libertad de asociación y no a la discriminación.

En América del Sur, está la Declaración Americana de los Derechos y Deberes del Hombre que agrupaba una serie de derechos sociales e individuales de la persona humana. El Documento fue reconocido internacionalmente y aprobado por la IX Conferencia Internacional Americana en Bogotá, en el mismo acto, también se aprobó la Carta Interamericana de Garantías Sociales, la concesión de derechos sociales del hombre americano, conocido como el Pacto de San José de Costa Rica, (1969). La Carta institucionalizó la Comisión Interamericana de Derechos Humanos en 1978 y solamente ha sido ratificada por Brasil en 1992. La Declaración Universal de Derechos 
Humanos (1948) es el documento inspirador de varios Pactos, Acuerdos y

Convenciones internacionales relativos a los derechos humanos fundamentales, lo que permite ampliar el debate en el ámbito del Derecho Internacional de los Derechos Humanos.

La Conferencia de las Naciones Unidas sobre el medio ambiente humano, establecida en 1972, conocida como la Declaración de Estocolmo, lleva en cuenta la necesidad de establecer unos criterios y principios que proporcionen los pueblos del mundo, la inspiración y guía para preservar y mejorar el medio ambiente humano, que hace una contribución significativa al medio ambiente laboral. Se predice que el hombre tiene el derecho fundamental a la libertad, la igualdad y el disfrute de condiciones de vida adecuadas, en un medio de calidad tal que permita una vida digna y gozar de bienestar, y tiene la obligación de proteger y mejorar el medio ambiente para las generaciones presentes y futuras.

\subsubsection{En la Organización Internacional del Trabajo (OIT)}

El Documento más importante en el proceso iniciado bajo la protección de los trabajadores a nivel internacional y en relación a la OIT es la Declaración sobre Principios y Derechos Fundamentales en el Trabajo (1998). Importante destacar las Convenciones no 29 de 1930 y la 105 de 1957 que están en consonancia con el artículo $4^{\text {o }}$ de la Declaración Universal de 1948, que prohíbe la esclavitud y la servidumbre en el lugar de trabajo. En comparación a la no discriminación, la convención nº 100 de 1951 establece la igualdad de remuneración por trabajo de igual valor y la convención n ${ }^{\circ} 111$ de 1958, la no discriminación en el empleo y la ocupación. Entre otras Convenciones en

que los derechos fundamentales de los trabajadores se consideran, destacamos las 
peores formas de trabajo infantil, en la Convención nº 182 de 1999 y nº 138 de 1973 que estipula la edad mínima de admisión al empleo.

Mientras tanto, la Convención $\mathrm{n}^{\mathrm{o}} 161$ relativa a los servicios de salud en el trabajo establece en su artículo $5^{\circ}$, que los servicios de salud en el trabajo deben garantizar las funciones que sean apropiadas y adaptadas a los riesgos de la empresa con respecto a la salud en el trabajo. La Organización en 2008 adoptó la Declaración sobre la justicia social para una globalización justa, basada en la Declaración de Filadelfia de 1944 y la Declaración sobre Principios y Derechos Fundamentales en el Trabajo de 1998. La Declaración adopta el modelo de trabajo decente, la institucionalización de su definición con los siguientes objetivos estratégicos: empleo, protección social, diálogo social y derechos en el trabajo. En 2002, la OIT publicó un informe sobre algunas maneras de configuración del acoso en el trabajo, enumerando varios comportamientos comunes. En este sentido, es importante decir que las normas dictadas por la OIT, según el informe antes mencionado, que prohíben el acoso en el lugar de trabajo y la Convención $n^{\circ} 111$ que prohíbe cualquier tipo de discriminación, deben ser observadas como verdaderos "sobre principios" dentro del ordenamiento jurídico interno, de cada Estado, cabiendo a ellos tomar las medidas necesarias para el efectivo respeto de estos derechos, realizando medidas preventivas y represivas.

\subsubsection{En el Mercado Común del Sur (MERCOSUL)}

Dentro del Mercosur, fue aprobado en 1988 la Declaración Socio Laboral, que incluye el análisis de las legislaciones laborales de los países dentro del bloque y directrices basadas en los derechos fundamentales en el trabajo amparado por la OIT. Cuanto a los Derechos Humanos de los trabajadores, el bloque parece favorecer 
la concepción de los derechos humanos como principios o directrices políticas. En el Documento, el tema relativo a los derechos individuales y la no discriminación en el empleo, se encuentra incorporados en las Constituciones de los cuatro países del Mercosur (Argentina, Brasil, Paraguay y Uruguay) garantizando los sueldos y la igual remuneración por igual tarea. El artículo $2^{\circ}$ de la Declaración establece que las personas con discapacidad serán tratadas con dignidad y sin discriminación, promoviendo su integración social en el mercado laboral.

\subsubsection{En la Unión Europea (UE)}

La Carta Social Europea, aprobada en Turín en 1961, ha venido reglamentar una serie de derechos y principios laborales. Entre ellos, se destaca el derecho a condiciones justas de trabajo, seguridad e higiene, la remuneración equitativa, el derecho a la organización sindical y el derecho a la negociación colectiva. La Directiva 2002/73 del Parlamento Europeo y del Consejo del 23 de septiembre de 2002 que modifica la Directiva 76/207/CEE del 1976, relativa al Principio de igualdad de trato entre hombres y mujeres en lo que se refiere al acceso al empleo, condiciones de trabajo y formación profesional.

Otra Directiva igualmente importante es la que se refiere a la dignidad del trabajador en la UE es la 2000/78CE de 27 de noviembre, que tiene por objetivo establecer un marco general para luchar contra la discriminación. En cuanto al acoso, el Documento afirma que esto se considera discriminación cuando una conducta no deseada con el propósito o efecto de atentar contra la dignidad de una persona o crear un ambiente de trabajo intimidatorio, hostil, degradante, humillante o desestabilizador. El mismo principio expuesto en la Directiva 2000/43/CE, de 29 de junio, relativa a la 
aplicación del principio de igualdad de trato de las personas independientemente de su origen racial o étnico, la afirmación de que el acoso constituye una discriminación, dañando así la dignidad humana.

La Carta de Derechos Fundamentales de la UE (2000), establece en su artículo $1^{\mathrm{o}}$ que la dignidad humana es inviolable y debe ser respetada y protegida, además, en virtud del artículo 20 trata del principio general de igualdad ante la ley y el articulo 21, dispone sobre a la no discriminación por motivos de raza, color, origen étnica, religión o convicciones, discapacidad, edad u orientación sexual, las causas mencionadas en el artículo 13 del Tratado Constitutivo de la Comunidad Europea. Aunque el artículo 23 de la Carta establece la igualdad entre hombres y mujeres en el empleo.

\subsection{Los Derechos Fundamentales del Trabajador en el Orden}

\section{Jurídico Brasileño}

La Constitución de la República Federativa de Brasil, valora el principio fundamental en su artículo $1^{\circ}$, inciso III, que previene la dignidad humana como piedra angular del Estado Democrático de Derecho. El principio de la no discriminación se presenta en los artículos $3^{\circ}, \mathrm{IV}, 5^{\circ}$ y $7^{\circ}$, caput y incisos $\mathrm{XX}, \mathrm{XXX}, \mathrm{XXXI}, \mathrm{XXXII}$ y XXXIV. En el ámbito infraconstitucional tiene a la protección a través de las leyes ordinarias 9.029/95, que prohíbe la exigencia de certificados de embarazo y esterilización u otras prácticas discriminatorias. Ya la ley 9.799/99 que emitió en la Consolidación de las Leyes Laborales (CLT), la Ley n ${ }^{\circ}$ 5.452/43 el artículo 373-A, ampliándose así las medidas contra la discriminación para que las mujeres puedan acceder al mercado de trabajo. Con respecto al acoso sexual, la Ley $\mathrm{n}^{\circ} 10.224$ de Brasil 
del 15 de mayo de 1991, que creó el artículo 216-A del Código Penal, define el acoso sexual como crimen. De modo que los principios son los pilares estructurales de la ley, la violación de ellos se considera tan grave como violaciones de las leyes. Sin embargo, no son raros los casos de violación de los principios fundamentales, especialmente en temas relacionados con el acoso moral, el acoso sexual y acoso por razón de sexo. Así siendo, con los medios de protección de los derechos y garantías fundamentales, que se insertan en los derechos de la personalidad, véase el artículo $5^{\circ}$, inciso $\mathrm{X}$ que cuenta con protección jurídica que el derecho de exigir al infractor a la indemnización por daños morales y materiales.

Además de la promoción y la valoración del trabajo, el legislador previó la protección a la salud de los trabajadores en los artículos 196 a 200. Por lo tanto, los valores humanos, sociales y del trabajo, su sentido y función social de la propiedad y por lo tanto del contrato, donde ocurre un pacto que tiene por objeto el trabajo humano, la protección y defensa del medio ambiente, recibió de la Carta, una protección especial que está prevista en los artículos $1^{\circ}$ III y IV; $6^{\circ}, 7^{\circ}$ y XXII; 170 III, 186 II, 193; 200 II y 225, con énfasis en la salud de los trabajadores.

En la Consolidación de las Leyes Laborales (CLT), hay un capítulo específico sobre seguridad y medicina del trabajo, en los artículos 189 y192. El texto aborda el concepto de actividades insalubres o peligrosas, el pago de los adicionales, así como el suministro de Equipo de Protección Personal (EPI's). Brasil ha ratificado varios acuerdos internacionales sobre el trabajo y la dignidad de los trabajadores, estableciendo que además de los derechos y garantías mencionadas en el art. $5^{\circ}$ de la $\mathrm{CF}$, no se excluyen otros decurrentes del régimen y de los principios adoptados por ella, o de los tratados internacionales en los que el país es signatario. 


\subsection{Los Derechos Fundamentales del Trabajador en el Orden}

\section{Jurídico Español}

La Constitución española de 1978 establece en su preámbulo una declaración de principios, es decir, la intención de garantizar la convivencia conforme un orden económico y social justo. Establece en su artículo $1^{\circ}$ que España es un Estado Social y Democrático de Derecho, afirmando los valores de la convivencia y la dignidad humana. Combina en su artículo 10 el valor de la dignidad humana y los derechos inalienables inherentes, como el libre desarrollo de la personalidad, el respeto a la ley y a los derechos de los demás, teniendo en cuenta estos fundamentos del orden político y la paz social. En el artículo 53.2, la Carta proclama el denominado procedimiento de amparo judicial y constitucional para proteger a los ciudadanos contra cualquier tipo de discriminación por razón de nacimiento, raza, sexo, religión, opinión o cualquier otra condición o circunstancia personal o social.

En el ámbito laboral, la vulnerabilidad de los derechos fundamentales se constituye cuando las actitudes del empresario son contrarias al artículo 35.1 de la CE con respecto a la libre elección del trabajo o del oficio, a través de la promoción de trabajo y la remuneración suficiente para satisfacer sus necesidades y de su familia, y que en ningún caso debe haber discriminación por razón de sexo. Los trabajadores a través de los sindicatos, adquieren una serie de derechos sociales, como podemos ver en el artículo 28 de la CE. Subrayamos la importancia de la Ley Orgánica 003/2007 de 22 de marzo para la igualdad efectiva de mujeres y hombres (LOIMH), en el artículo $7^{\circ}$, la norma trata del acoso sexual, establece principios para la actuación de los poderes públicos, regula los derechos de las personas físicas y jurídicas tanto públicas como el 
sector privado y prevé medidas destinadas a eliminar y corregir toda forma de discriminación por razón de sexo.

Lo que se refiere al Estatuto de los Trabajadores (ET), el artículo 50 prevé la extinción del contrato de trabajo por parte del empleado por incumplimiento grave por parte del empresario de cualquiera de las cláusulas en el contrato firmado por él. Este comportamiento empresarial puede percibirse como falta de cumplimiento de la obligación impuesta por la ley para garantizar el derecho de todos los trabajadores a su integridad física en virtud del artículo 4.2 d) del mismo Documento; O incluso sobre la intimidad y la consideración de la vida a su dignidad como se indica en el 4.2 y también para llevar a cabo una adecuada política de seguridad en el trabajo que puede ser causa de rescisión de contrato de trabajo. El comportamiento empresarial expuesto, también es contrario al artículo 8.11 de la Ley sobre Infracciones y Sanciones en el Orden Social (LISOS), aprobada por el Real Decreto 5/2000, de 04 de agosto, considerado como un acto contrario al respeto de la intimidad y la dignidad de los trabajadores.

\subsection{La Protección para la Seguridad y para la Salud del Trabajador} en Brasil y España: un cuadro comparativo

Las normas de Derecho del Trabajo tenían por objetivo cumplir con las obligaciones negativas en relación a los trabajadores y al Estado, que prohibían la práctica de actos que podían poner en riesgo la integridad física y mental del trabajador, pero también generó obligaciones positivas como las de implementar medidas necesarias para la preservación y protección de la salud del trabajador por parte del Estado. 
Entre las estrategias adoptadas por la mayoría de la legislación brasileña, hay dos que merecen una mención: a) la prohibición de desarrollar actividades insalubres y peligrosas y la compensación financiera para cualquier persona que ejerza tales actividades. La CLT en su artículo 191 establece que corresponde al empresario la adopción de medidas para neutralizar o eliminar el ambiente de trabajo insalubre. En el artículo 166 de la misma norma, demuestra que el empresario debe fornecer a los empleados de forma gratuita los EPI's. También es importante señalar, que el CF de Brasil en su artículo 21 XXIV, se estipula que la Unión (léase Estado Federal) debe organizar, mantener y ejecutar la inspección de trabajo, dentro del ámbito del Poder Ejecutivo Federal, una tarea que compete al Ministerio de Trabajo y Empleo.

En Brasil, existe disposición legal del Servicio Especializado en Ingeniería de Seguridad y Medicina de Trabajo (SESMT), regulado por la Portaría $\mathrm{n}^{\mathrm{o}}$ 3.214 de 08 de junio 1978, por NR4 y el artículo 162 de la CLT que pretende asegurar, proteger y promover la salud y la integridad del trabajador en el lugar de trabajo. También contamos con la Comisión Interna de Prevención de Accidentes (CIPA), cuyo objetivo es observar e informar a las condiciones de riesgos en el lugar de trabajo.

El artículo 49 de la CE, que dispone a respeto de las personas con discapacidades físicas, sensoriales o psíquicas, afirma que las mismas recibirán atención especializada. El artículo 51 está dedicado a la salud del consumidor, pero también hay otros artículos estrechamente relacionados con el tema, como los artículos 41 y 45, que dan lugar a la conservación y protección del medio ambiente y el uso adecuado de los recursos naturales.

Con respecto a la salud pública y las medidas que el poder público debe adoptar en relación a ella, es posible subrayar la Ley General de Sanidad (LGS 
14/1986), como el desarrollo normativo del artículo 43 de la CE, que consagra el derecho de toda persona a la protección a la salud integral y en condiciones de plena igualdad. La misma importancia se da al artículo 40.2, que reconoce el derecho a la salud o a la seguridad e higiene en el trabajo. Aún en España, es importante la Ley 31/1995, de Prevención de Riesgos Laborales (LPRL) que sigue a un mandato constitucional de desarrollar una política para proteger la salud de los trabajadores mediante la prevención de riesgos laborales, trayendo también las diferentes acciones preventivas en coherencia con las decisiones de la Unión Europea.

En términos de seguridad y salud de los trabajadores en el ámbito Europeo, ha adoptado una amplia gama de medidas sobre la cuestión en el artículo 137 del Tratado de la CE. La Directiva Marco 89/391 de 1989 sobre la aplicación de medidas para promover la mejora de la seguridad y la salud ocupacional en el lugar de trabajo. Una de las obligaciones de los empresarios citados en la Directiva, es que ellos deben llevar a cabo evaluaciones periódicas de los riesgos profesionales y la elección de los equipos de trabajo en condiciones de organizar los servicios de prevención. En este sentido, consideramos que las medidas preventivas en el lugar de trabajo y su respectivo acompañamiento de los posibles accidentes o enfermedades laborales son capaces de minimizar los riesgos a que los trabajadores se encuentran sujetos.

\section{LOS RIESGOS LABORALES Y PSICOSOCIALES EN EL LUGAR DE TRABAJO}

\subsection{Las Enfermedades Provenientes del Ambiente Laboral}


Según el Instituto Sindical de Trabajo, Ambiente y Salud (ISTAS), los riesgos psicosociales dañan a la salud de los trabajadores, causando estrés y en el largo plazo, enfermedades cardiovasculares, respiratorias, gastrointestinales, dermatológicas, endocrinológicas y mentales. El estrés se define como la suma de las respuestas físicas y mentales causadas por ciertos estímulos externos que permiten al individuo superar las exigencias del medio. La Agencia Europea para la Seguridad y la Salud en el Trabajo (OSHA) estima que el estrés laboral es uno de los principales problemas que enfrentan los trabajadores, mostrando que el $50 \%$ al $60 \%$ de ausencias en el trabajo están relacionados con este problema, generando así el sufrimiento humano y daños a la economía de las empresas y del mercado. Algunos expertos señalan que los síntomas como signos de advertencia incluyen: dolores musculares, de cabeza, cansancio, irritabilidad, cambios en el sueño, en la alimentación y vida sexual, incluso puede causar trastornos físicos, tales como enfermedades gastrointestinales, cardiovasculares y respiratorias, los trastornos psicológicos como la ansiedad, los miedos, las fobias, el consumo excesivo de alcohol y drogas, depresión, trastornos afectivos, trastornos de la personalidad y la esquizofrenia.

Otra enfermedad que se debe al entorno laboral es el Síndrome de Burnout. Hoy en día, el término es utilizado por expertos en la salud mental para describir un avanzado estado de estrés, cuya causa es exclusivamente el ambiente de trabajo. La enfermedad se caracteriza por el estrés crónico, que sufren los profesionales que trabajan en un entorno difícil y hostil. El síndrome se atenúa en fase avanzada de estrés, que se caracteriza por un conjunto de signos y síntomas de diversas causas que pueden ser de orden psicológicas o físicas. Los síntomas son variados, tales como el desaliento y la falta de motivación para el trabajo que puede resultar en enfermedades psicosomáticas que conducen a los profesionales a frecuentes ausencias en el trabajo, la 
baja temporal debido a la enfermedad e incluso, en casos extremos, jubilación por incapacidad.

Brasil muestra un aumento significativo en los casos de trastornos mentales de los trabajadores, y esto ha sido una preocupación importante que ha ocupado la agenda médica y el Instituto Nacional de la Seguridad Social (INSS) del Ministerio de Bienestar Social. La enfermedad es la tercera en el ranking de las principales causas de los pedidos de auxilio de asistencia en el INSS. En Brasil, no existe una legislación específica para estos casos, a pesar del anexo II del Decreto $n^{\circ}$ 3.048 del 06 de mayo 1999 (revocado), haber incluido la depresión como una enfermedad profesional. Aún así, sólo se considera como una enfermedad derivada de medio ambiente de trabajo donde el contacto con algunos productos químicos tóxicos específicos. En caso de duda sobre su origen, la acción es siempre en beneficio del trabajador, amparándole, como la comprensión del artículo 21, I, de la Ley no 8.213/91. Una vez caracterizada la depresión como una enfermedad profesional, el trabajador tiene garantizado el Auxilio de Enfermedad Accidental, previsto en el artículo 118 de dicha ley. Confirmada la depresión, el trabajador es dado de baja de la actividad laboral y pasa a recibir el Auxilio Enfermedad (artículo 59 a 61). Queda todavía una laguna en la legislación en lo que se dice respeto al acoso, ya que la depresión puede ser una de las consecuencias de tal conducta.

En España, según la Unión General de los Trabajadores (UGT), en cifras globales durante los primeros nueve meses de 2009 fueron 12.390 enfermedades profesionales registradas. En consecuencia, la UGT y el Observatorio Permanente de Riesgos Psicosociales (OPRPS) realizó una encuesta con una muestra de 4.000 trabajadores pertenecientes a los sectores: textil, hostelería, enseñanza, sanidad, 
telecomunicaciones, teleoperadores, cárnicas, conservas vegetales, azulejo, aéreo, comercio y seguridad privada. Se constató que el $75 \%$ de los trabajadores encuestados sufren de estrés laboral, el $81 \%$ sufren del síndrome de burnout, el 8\% están expuestos a un ambiente de trabajo en el que habitualmente se produzcan actos de violencia verbal y/o psicológica y el 16\% tienen un riesgo elevado de sufrir por acoso psicológico en el trabajo.

\subsubsection{La Violencia}

La violencia se manifiesta como un fenómeno complejo, de modo que no podemos establecer un concepto único, por lo que no tienen la pretensión de agotarlo, ni siquiera hablar de violencia urbana (crimen y delincuencia). Por lo tanto, afirmamos que la violencia es un comportamiento que causa daño a otra persona, negando su autonomía, su integridad física o psicológica. Es el uso excesivo de la fuerza, además de lo necesario o esperado. Según la OMS, la violencia es la imposición de un grado significativo de dolor y sufrimiento evitable. Para el Ministerio de Salud de Brasil, la violencia es un caso representado por las acciones realizadas por los individuos, grupos, clases o naciones que causan daño físico, emocional, moral, espiritual, a ellos mismos o a los otros, por ejemplo, la agresión física, el abuso sexual, la violencia psicológica y la violencia institucional. Según ALKIMIN, la violencia en las relaciones laborales viola los derechos fundamentales de la persona e infringe su dignidad. Incluye también, las amenazas, la discriminación, la intimidación, el abuso, la persecución que induce al miedo, la exclusión y la indiferencia en el trabajo. Dentro de este ámbito, la violencia psicológica es el uso deliberado del poder, acción u omisión que puede resultar en daños a la salud física, mental, espiritual, moral y sexual, que van desde la agresión verbal, actitudes discriminatorias, el acoso moral y hasta el sexual. 


\subsubsection{El Acoso Moral}

El acoso moral es la exposición de los trabajadores y trabajadoras a situaciones humillantes y de constreñimientos, repetitivas y prolongadas durante la jornada laboral o en el ejercicio de las funciones de su trabajo. El acoso moral es más común en las relaciones jerárquicas autoritarias donde predomina la relación poco ética con sus subordinados, desestabilizando a la víctima en el lugar de trabajo. Es un fenómeno social difícil de probar o caracterizar, las actitudes que tipifican el acoso en el lugar de trabajo son: abuso de autoridad (dictar órdenes imposibles para el trabajador, dejarlo sin ocupación e incomunicable, exigir tareas inútiles y que carecen de valor productivo, hacer represalias con aquellos que denuncien o demanden en contra de la empresa ), disponer de tratamiento degradante (insultar o menospreciar a la víctima en repetidas ocasiones ante los demás, haciendo chismes falsos sobre la vida y el trabajo de la víctima), el acoso discriminatorio (por las creencias religiosas, sexo u orientación sexual, edad, estado civil, nacionalidad, origen étnico, origen nacional o discapacidad).

Se recuerda que el ordenamiento jurídico brasileño no existe una ley específica que se refiere al acoso en el lugar de trabajo en sus diversas manifestaciones. Sin embargo, el Tribunal Superior del Trabajo (TST) ya está reconociendo el problema en varios casos donde las víctimas de acoso requieren reparaciones por los daños causados por las empresas. Hasta la presente fecha tramita en la Cámara de los Deputados un Proyecto de Ley Federal, PL 4742/2001 que pretende incluir el artículo 146-A del Código Penal Brasileño. Algunas ciudades brasileñas han adoptado leyes municipales y varios proyectos de leyes que se tramitan en las Asambleas Legislativas de los Estados. 
El interés en el estudio ha hecho que la doctrina identificara comportamientos diferentes de acoso moral, dependiendo de cómo se manifiesta. Así, es posible hablar de acoso descendente, acoso ascendente y el acoso horizontal. El acoso descendiente ocurre cuando un individuo tiene una relación de cierto poder dentro de la empresa y acosa a uno o más trabajadores que están subordinados a él. El ascendente ocurre cuando el acosado es una persona que ocupa una posición más alta dentro de la empresa, que es atacado por un o más de sus subordinados. Y el acoso horizontal es aquel que se produce entre compañeros del mismo nivel jerárquico dentro de la empresa. Sucede debido a la competencia de puestos de trabajo y promoción.

\subsubsection{El Acoso Sexual}

El acoso sexual, aunque no es un tema novedoso en la organización del trabajo en los últimos tiempos, ha ganado más notoriedad debido a caracterizar una forma de violencia en la relación de trabajo, que denigra la personalidad y la dignidad humana. Sin duda, el acoso sexual en el trabajo, es un fenómeno de los temas laborales en curso. La conducta presupone una relación de poder entre el acosador y acosado, pero no es el requisito esencial, por lo tanto, el acoso también puede ocurrir entre compañeros de trabajo, entre el empleado y el cliente y el empleado y el empleador. Considerando que, en la mayoría de los casos reportados, el sujeto activo del acoso sexual es una conducta del hombre, y que las mujeres son las víctimas más comunes, aunque también puede funcionar a la inversa, no se descarta la posibilidad de crear el acoso entre personas de mismo sexo.

El acoso sexual se divide en dos clases: acoso sexual por chantaje y acoso sexual por intimidación. El acoso mediante el chantaje puede ser una exigencia 
del jefe o superior jerárquico a un subordinado suyo, por lo que se presta a la actividad sexual si quiere mantener el empleo, garantizar una promoción o incluso un aumento de sueldo. El acoso sexual se produce mediante la intimidación a través de expresiones de carácter sexual, con el objetivo de afectar el desempeño de la víctima, creando el ambiente de trabajo hostil por la intimidación y por el abuso.

La conducta es una forma de discriminación contra el trabajador o trabajadora. El derecho a la libertad sexual se refiere al derecho a la intimidad y la privacidad, también relacionados con el derecho a la integridad física, que incluye el derecho a su propio cuerpo, por lo tanto el acoso sexual viola los Derechos Humanos y su conducta atenta contra la dignidad del trabajador.

\subsubsection{El Acoso por Razón de Sexo}

Esta forma de acoso, no se materializa con el objetivo sexual, como en el caso de acoso sexual, pero cuando el acosador persigue, intimida o discrimina la víctima en función del género. Es importante destacar que la configuración del acoso como un comportamiento discriminatorio por razón de sexo debe disponer de una relación de existencia con el sexo de la víctima, por lo que esta es la razón principal de la conducta del acosar, que ataca a la víctima por ser mujer u hombre diferentemente del acoso sexual que vimos anteriormente.

Es importante comentar sobre el principio de igualdad que se reconoce en los documentos internacionales más relevantes, como en la Carta de las Naciones Unidas (1945) y la Declaración Universal de Derechos Humanos (1948). En el caso de la Carta de las Naciones Unidas de 1945, consagra el principio de no discriminación en el artículo $1^{\circ}$, apartado $3^{\circ}$ del artículo 55, y también en el artículo 76. En su exposición 
de motivos, se refiere a la igualdad de derechos entre hombres y mujeres. En la Declaración Universal de Derechos Humanos (1948) en su artículo $1^{\circ}$ y artículo $2^{\circ}$, establece el principio de no discriminación.

En España, LOIMH del 22 de marzo de 2007, cuyo objetivo es crear una igualdad efectiva entre hombres y mujeres, enseña en uno de sus capítulos una cuestión importante que es "Plan de igualdad para las empresas u otras medidas de promociones de igualdad". Esto contribuye que las empresas presten atención a las estrategias en su ámbito de gestión en la formulación y aplicación efectiva de este importante principio de Derecho: la igualdad de oportunidades y el derecho a un tratamiento no discriminatorio.

En América Latina, además de Brasil, Costa Rica y Chile tienen índices que muestran una significativa diferenciación de sueldo entre hombres y mujeres. Este tipo de acoso está aún presente en el mercado de trabajo en Brasil, como en el caso de las variaciones de los salarios pagados a los hombres y mujeres, o cuando se trata de promociones, los hombres abren distancia considerable hacia las mujeres. Estos derechos se refieren también a competir en el mercado de trabajo, a recibir igual remuneración que los hombres cuando realizan el mismo trabajo y que ascienden a las mismas oportunidades profesionales.

\subsection{Las Consecuencias de la Conducta de Acoso para el}

\section{Trabajador y para la Empresa}

Cuando el trabajador sufre el acoso en el ambiente de trabajo, su salud es afectada, pudiendo presentar casos de depresión, estrés, trastornos psicosomáticos, ansiedad, apatía, tristeza, nerviosismo, desesperanza, culpa, crisis de autoestima, 
trastornos emocionales y sociales, conflictos familiares y trastornos del sueño. En el ambiente de trabajo, tiene una menor productividad, pérdida de motivación y creatividad y el absentismo. En general, el asediado comienza a tener dificultades de relacionamientos, tiende a aislarse, asociando la labor a un ambiente hostil y de sufrimiento.

La empresa también se ve afectada cuando ocurren problemas de acoso o violencia en el lugar de trabajo. Como resultado, la productividad disminuye, la falta de comunicación dificulta la transmisión y ejecución de las tareas, reduce la calidad de trabajo, hay una caída de la productividad y los cambios en la calidad del servicio/producto, se manifiestan las enfermedades profesionales y los accidentes de trabajo, daño a los equipos, una alta rotación de mano de obra y una queda lucrativa.

El acoso en el trabajo proyecta también efectos negativos para la sociedad, ya que el Estado tiene que asumir altos costos en relación con la salud pública, asistencia y bienestar social con los tratamientos de rehabilitación profesional. También debe conceder las prestaciones por razón de alejamiento por licencia salud de los trabajadores afectados. Sin duda, este es un problema que requiere la intervención de los poderes públicos, teniendo en cuenta las graves consecuencias para los trabajadores, los altos costos que sufren las economías de las empresas y el daño que afecta al sistema de salud pública.

\section{GESTIÓN EMPRESARIAL Y DERECHOS HUMANOS}




\subsection{La Ética y los Códigos de Conducta Empresariales}

La ética es un conjunto de principios y valores que orientan y conducen las relaciones humanas. Estos principios deben tener características universales y deben ser válidas para todos y para siempre. La definición más sencilla es la que dice que la ética es un conjunto de valores, principios universales que rigen la relación de las personas. La ética es mucho más amplia, general y universal que la moral. Tiene que ver con principios más amplios, mientras que la moral se refiere más a determinadas áreas de la conducta humana.

Toda organización tiene un Código de Ética que intenta dar cuenta de los comportamientos deseados para el ambiente de trabajo y debe representar los valores discutidos y negociados por la administración de la Organización con el objetivo de ser traducida en las acciones del día a día empresarial. El Código de Ética, es una herramienta redactada por la empresa, que se basa en sus valores y principios que ayudan a lograr su visión y misión.

Ya el Código de Conducta de una empresa es un guía con las reglas que orientan la actuación y las prácticas organizacionales, donde los principios del Código de Ética se detallan. El Código de Conducta aborda temas como la legislación, el medio ambiente, la corrupción, la confidencialidad y el acoso. El documento en general está destinado a los trabajadores y su enfoque se centra más en las reglas de conformidad. En este sentido, la participación de los Stakeholders y la transparencia del Código de Conducta, son la clave para evitar posibles dudas sobre las reglas y principios de la empresa. 
Los códigos de Ética deben ser herramientas eficaces de gestión y, por tanto, la empresa debe fortalecer y promover los valores ya existentes, revisando los demás y creando una nueva conciencia. Es ahí que entra el área de Recursos Humanos o Gestión de Personas de la empresa, que es esencial porque es ella la que siembra la importancia de la ética, que la adopta como valor institucional, pidiendo a todos los niveles de la organización a participar en el desarrollo democrático y aplicación de un código de conducta interno. La tendencia de las grandes empresas, citamos aquí, las empresas multinacionales, en particular, es de tutelar los derechos fundamentales de los trabajadores, transfiriendo esta responsabilidad que sería del Gobierno para la iniciativa privada, enfatizando la idea de la actuación social responsable y redimensionando el principio de subsidiariedad. Las empresas asumen, de esta manera, la responsabilidad social y garantizan los derechos sociales de los trabajadores cuando se disponen de la protección de los Derechos Humanos a través de sus Códigos de Conducta.

\subsection{La Responsabilidad Social Empresarial}

Establecer la relación entre Derechos Humanos, empresa y mundo corporativo, en poco tiempo atrás, era impensable. Hasta entonces, los Derechos Humanos eran discutidos en la esfera del Estado y no en la esfera del privado. Actualmente, relacionar empresa con Derechos Humanos es un paradigma nuevo, en lo que la empresa debe llevar en consideración sus estrategias de gestión respetando las normas internacionales de los Derechos Humanos. Es en este proceso, que surge la concepción de la empresa socialmente responsable.

Las empresas, tanto las multinacionales o comerciales que operan en diferentes países, enfrentan constantes desafíos en varios aspectos. Las nuevas 
tecnologías, la globalización de los mercados, las presiones sindicales, la calidad de vida laboral en el trabajo, la nueva legislación sobre los intercambios comerciales, gestión de calidad y nuevas estrategias son las constantes demandas que deben observar para adaptarse al mercado mundial. Sobre esta base, la globalización conlleva la necesidad de las empresas a adaptarse a un nuevo contexto, asumiendo la responsabilidad con la vida de las personas y el medio ambiente. Por lo tanto, no debe permanecer ajena a este hecho.

El debate sobre la responsabilidad social de las empresas se centra en el comportamiento social, del trabajo y ambiental de las grandes empresas, especialmente las multinacionales, porque se consideran las principales responsables por el crecimiento económico mundial. Las principales referencias sobre el tema, tanto en Brasil como en Europa, son el Pacto Mundial Global (2000), la Declaración Tripartita de la OIT sobre Empresas Multinacionales y Política Social (1977, $1^{\text {a }}$ edición), los Principios y Derechos fundamentales del Trabajador (1998), las Directrices para Empresas Multinacionales de la OCDE (2000). En Brasil, se hace hincapié a la Declaración de Río y la Agenda 21 de la ONU.

Una empresa socialmente responsable es aquella que se compromete públicamente a seguir las normas internacionales y envuelve las partes interesadas en el acompañamiento de sus prácticas, estableciendo relaciones saludables con ellas, teniendo en cuenta sus intereses por medio de mecanismos de consulta y participación, desarrollando sus negocios en formas a beneficiar a todos, incluyendo los grupos que componen la cadena de producción, que buscan generar empleo estable, lo que contribuye a la distribución equitativa de la riqueza y la reducción de la exclusión de grandes grupos. Sin embargo, estos supuestos no están muy presentes en el escenario 
empresarial y el número de empresas que ejercen una cultura de responsabilidad social es aún muy pequeño, especialmente en lo que respecta a los Derechos Humanos de los trabajadores.

\subsection{Directrices para Empresas Multinacionales de la Organización} para la Cooperación y Desarrollo Económico (OCDE)

En el año de 1976, la OCDE elaboró las Directrices para Empresas Multinacionales que, desde 1992, han sido sometidas a una revisión con el fin de encajar en el nuevo contexto económico; y en 1999, los países miembros acordaron incluir las normas laborales en el Documento. Sólo, entonces, en el año de 2000, ha sido concluida la nueva versión de las Directrices con la participación de Organizaciones no Guvernamentales y de los países no miembros como Brasil.

El objetivo de las Directrices es garantizar que las actividades corporativas estén en consonancia con las políticas gubernamentales, estableciendo una relación de confianza con la sociedad en que operan. También aspira a mejorar el clima para la inversión extranjera, lo que contribuye al desarrollo sostenible realizado por las empresas multinacionales.

Las líneas Directrices dedican un capítulo aparte la cuestión de las relaciones empresariales y el empleo. Se compone de los derechos fundamentales del trabajador, como el derecho a ser representado por un sindicato, la eliminación del trabajo infantil y trabajo forzoso, la prohibición de la discriminación contra el trabajador, la aplicación de medidas para garantizar la salud y seguridad en el trabajo. 


\subsubsection{La Declaración Tripartita de Principios Sobre Las Empresas}

Multinacionales y la Política Social de la OIT

La Declaración Tripartita de Principios Sobre las Empresas Multinacionales ha sido aprobada por el Consejo de Administración de la OIT de la Oficina Internacional del Trabajo en su 204 a Reunión en Ginebra en 1977 y revisada en 2000. El Documento es una recomendación a los gobiernos, las organizaciones de empleados, empleadores y de las empresas multinacionales. Su adopción tiene carácter voluntario, no teniendo relación con las obligaciones causadas por la ratificación de una Convención de la OIT.

De acuerdo con la política social, la Declaración establece que todas las partes deben respetar los derechos soberanos, observando las normas jurídicas nacionales, teniendo en cuenta las prácticas locales y respetar las normas internacionales. Según la OIT, las empresas multinacionales desempeñan un papel importante en las economías de los países donde están localizadas y en las relaciones económicas internacionales, tanto para los empleadores, los trabajadores y de sus respectivas organizaciones. Las recomendaciones en relación a los derechos fundamentales de los trabajadores son el fomento del empleo, donde los gobiernos deben estimular el crecimiento y el desarrollo económico mediante la promoción de políticas en este sentido.

En lo que dice respecto a la seguridad y a la higiene en el ambiente de trabajo, las empresas deben aplicar las normas nacionales que regulan esta materia, incluyendo las cuestiones que tengan relación con el tema, previstas en los convenios colectivos en conjunto con los representantes de los trabajadores. Cuanto a las 
relaciones de trabajo el documento afirma que todo trabajador tiene derecho a la sindicalización o a la creación de organizaciones que creen conveniente.

\subsubsection{El Pacto Global (Global Compact) de la Organización de las}

\section{Naciones Unidas para las Empresas}

El Pacto Global es una iniciativa voluntaria de las Naciones Unidas con el objetivo de movilizar a la comunidad empresarial internacional a adoptar en sus prácticas comerciales, valores fundamentales en las áreas de Derechos Humanos internacionalmente aceptos, trabajo, medio ambiente y lucha contra la corrupción. La iniciativa surgió durante el Foro Económico Mundial de Davos en 1999, a partir de la propuesta del Secretario General Kofi Annan. Construído con el propósito de reflexionar y discutir la cultura de la responsabilidad social de las empresas, no tiene una estructura rígida y no es un Código de Conducta obligatorio.

La red se compone de cinco agencias de la ONU: Oficina del Alto Comisionado para los Derechos Humanos (ACNUR), Organización Internacional del Trabajo (OIT), Programa de las Naciones Unidas para el Medio Ambiente (PNUMA), Organización de las Naciones Unidas para el Desarrollo Industrial (ONUDI) y Programa de las Naciones Unidas para el Desarrollo (PNDU). Los diez principios del Pacto Mundial están basados en un consenso universal y en cuatro instrumentos internacionales: la Declaración Universal de los Derechos Humanos (1948), la Declaración Internacional del Trabajo Relativa a los Principios y Derechos Fundamentales en el Trabajo (1998), la Declaración de Río de Janeiro sobre el Medio Ambiente y Desarrollo Sostenible (1992) y la Convención de las Naciones Unidas contra la Corrupción (2003). 
Al unirse al Pacto Mundial de las Naciones Unidas, las empresas demuestran su compromiso con los siguientes principios: Las empresas firmantes deben apoyar y respetar la protección de los Derechos Humanos internacionalmente reconocidos como el primer principio del Pacto. El segundo principio establece que deben cerciorarse de que no van a participar en cualquier tipo de acción que lleva a la violación de los derechos reconocidos internacionalmente.

El tercer principio del Pacto establece que las empresas deben apoyar la libertad de asociación y el reconocimiento del derecho a la negociación colectiva de los empleados. La observancia de los derechos laborales es la principal herramienta para las empresas para influir y contribuir a la promoción de los Derechos Humanos, ya que sin esto, no hay necesidad de hablar de responsabilidad social corporativa. Esto incluye también el derecho a la libertad de expresión, la libertad de asociación y negociación colectiva. El cuarto principio es la eliminación de todas las formas de trabajo forzoso u obligatorio. Como quinto principio, las empresas firmantes del Pacto Global deben ayudar a eliminar de manera efectiva el trabajo infantil. Eliminar la discriminación en el empleo, es el sexto principio del Pacto. El principio de igualdad forma parte de la lista de derechos y libertades fundamentales y la discriminación en el trabajo es una negación de ese principio.

El séptimo principio de la iniciativa dice que las empresas deben apoyar un abordaje preventivo a los desafíos ambientales. La Educación Ambiental para las empresas debe ser un proceso continuo de aprendizaje, ya que la mejora del medio ambiente del entorno facilita también la mejora del medio ambiente laboral, pudiendo evitar casos de violación a los Derechos Humanos, incluso de acoso. Las empresas deben fomentar las iniciativas que promuevan una mayor 
responsabilidad ambiental, es el principio octavo de la iniciativa. Incentivar la difusión de tecnologías ecológicas, viene como nono principio. Finalmente, como el décimo principio tenemos el combate a la corrupción en todas sus formas, incluidas extorsión y soborno. Combatir la corrupción es actualmente uno de los mayores retos en el mundo. Ella es un obstáculo para el desarrollo económico, especialmente, en los países subdesarrollados.

Así siendo, las empresas se comprometen a construir sus estrategias dentro de los diez principios universalmente propuestos, contribuyendo para la creación de un mercado global más estable. La iniciativa ya cubre más de 100 países de todo el mundo, como Brasil y España.

\subsubsection{Las Normas de Derechos Humanos para las Empresas de las}

\section{Naciones Unidas}

Las normas de la ONU para las empresas están compiladas en una declaración o una lista de obligaciones empresariales en el ámbito de los Derechos Humanos. Fueron adoptadas por la Subcomisión de la ONU para la Promoción y Protección de los Derechos Humanos. En 1997, la misma Subcomisión, realizó un estudio sobre las empresas transnacionales y los Derechos Humanos, y en 1999 comenzó el proyecto de redacción de un Código de Conducta para las empresas con la participación de los interesados en la materia.

Las normas de la ONU de los Derechos Humanos para las empresas deben ejecutarse dentro de los límites de la esfera de actividad e influencia de las mismas. Por lo tanto, las normas exigen que "ellas promuevan, garantizan, respetan y hacen cumplir y proteger los Derechos Humanos consagrados en el derecho 
internacional y en la legislación nacional en los estados donde están inseridas". Las disposiciones llaves de las normas engloban:

- Obligaciones generales: Bajo el supuesto de que los Estados tienen la obligación de promover y proteger los Derechos Humanos consagrados en la legislación internacional y nacional, incluso haciendo que las empresas respeten estos derechos dentro del ámbito de sus actividades en los países en que ejercen su funciones, asegurando que estas actividades no contribuyan directa o indirectamente en ocasionar prejuicios a los seres humanos.

- Derecho a la igualdad de oportunidades $y$ trato no

discriminatorio: Las empresas deben garantizar la igualdad de oportunidades, a fin de eliminar toda discriminación basada en la raza, el color, el sexo, el idioma, la religión, la opinión política, origen nacional o social, condición social, por pertenecer a un pueblo indígena y edad.

- $\quad$ Derecho a la seguridad personal: Las empresas no cometerán actos que contribuyan o se constituyan crímenes de guerra, crímenes contra la humanidad, el genocidio, la tortura y los trabajos forzosos u obligatorios, toma de rehenes, ejecuciones sumarias o arbitrarias, según se define en el Derecho Internacional, en particular, en las normas de Derechos Humanos y en Derechos Humanitarios.

- Derecho de los trabajadores: Las empresas no recurrirán al trabajo forzoso $\mathrm{u}$ obligatorio prohibido en los instrumentos internacionales y la legislación nacional pertinente, así como las normas internacionales de Derechos Humanos y Derecho Internacional Humanitario.

- Respeto a la soberanía nacional y de los Derechos Humanos: Las empresas observarán y respetarán las normas del derecho internacional, leyes, 
reglamentos nacionales y las prácticas administrativas, el estado de derecho, el interés público, objetivos de desarrollo, las políticas sociales, económicas y culturales, incluidas la transparencia, la responsabilidad y prohibición de la corrupción, y la autoridad en los países que llevan a cabo sus actividades.

- Obligaciones relativas a la protección de los consumidores: Las empresas actuarán en consonancia con las prácticas comerciales y publicitarias leales y adoptarán cuantas medidas sean necesarias para garantizar la seguridad y la calidad de los bienes y servicios que ofrecen. No producirán, distribuirán, comercializarán productos dañinos o potencialmente dañinos para el uso de los consumidores.

- Obligaciones relativas a la protección del medio ambiente: Las empresas llevarán a cabo sus actividades de conformidad con las leyes, reglamentos, prácticas administrativas y las políticas nacionales relativas a la conservación del medio ambiente en los países donde realizan sus actividades, así actuarán en conformidad con los acuerdos, principios, objetivos, responsabilidades $\mathrm{y}$ normas internacionales pertinentes relativas al medio ambiente y los Derechos Humanos.

\subsection{Las Iniciativas de la Sociedad Civil}

\section{Global Reporting Initiative (GRI)}

El Global Reporting Initiative presenta Directrices para padronización de informes de sostenibilidad y apareció en 1997 en asociación con la Coalición de Economías Ambientalmente Responsables (CERES), y el Programa de las Naciones Unidas para el Medio Ambiente. La propuesta principal es desarrollar las Directrices 
para la elaboración de informes de sostenibilidad, siendo una gran red de Multistakeholder compuestas por expertos de varios países alrededor del mundo.

Entre los indicadores de desempeño del GRI están las siguientes categorías: prácticas laborales y trabajo decente (empleo, relaciones laborales y gestión, la salud y la seguridad, la formación y la educación, diversidad y oportunidades) y los Derechos Humanos (estrategia y gestión, la no discriminación, la libertad de asociación y negociación colectiva, trabajo infantil, trabajo forzoso, las prácticas de seguridad y los derechos indígenas). Ya son más de mil organizaciones en el mundo que producen informes de sustentabilidad con base en la versión de la GRI.

\section{El Informe Social del Instituto Brasileño de Análisis Sociales y}

\section{Económicos (IBASE)}

El Instituto Brasileño de Análisis Sociales y Económicos (IBASE) surgió en 1981 y visa dar transparencia a las actividades empresariales a través de la difusión de informes y ampliar el diálogo con la sociedad. Por otra parte, es una excelente herramienta de gestión para que la empresa evalúe su nivel de responsabilidad social. Los elementos de verificación de que las empresas deben proporcionar al presentar sus informes al IBASE son: educación, salud, atención a las mujeres, el trabajo en la preservación del medio ambiente, la mejora de la calidad de vida laboral de los empleados y los proyectos de apoyo a la comunidad, con objetivo de erradicar la pobreza, generación de ingresos y nuevos puestos de trabajo.

Social Accountability 8000 e ISO 26000 
Además de las iniciativas, que sugieren que las empresas hagan públicos sus indicadores de gestión en relación con los derechos fundamentales de los trabajadores y la responsabilidad social a través de informes, están aquellos que tienen por objetivo establecer padrones de calidad. La Social Accountability 8000 (SA8000) fue lanzada en 1997 por la Council on Economics Priorities Accreditation Agency (CEPAA), y ahora se conoce como Social Accountability International (SAI). La norma se presenta como un sistema de auditoría similar a la ISO9000, con condiciones basadas en las Directrices Internacionales sobre Derechos Humanos y las Convenciones de la OIT.

Entre las cuestiones abordadas por la norma están la salud y la seguridad en el trabajo, la discriminación, la libertad de asociación y derecho a la negociación colectiva, trabajo infantil y trabajo forzoso, la carga de trabajo y horas de trabajo, beneficios para los trabajadores y el sistema de gestión. Se está elaborando la ISO26000 y esta iniciativa será la norma internacional de responsabilidad social, espera que esté terminado en 2010. Los responsables de la redacción de la norma son: el Instituto Sueco de Normalización Swedish Standards Institute (SIS) y la Asociación Brasileña de Normas Técnicas (ABNT). Un proyecto de ISO26000, adelanta que abordará cuestiones de Derechos Humanos, contemplando la igualdad de oportunidades, que incluye la diversidad, la no discriminación, la igualdad de género, derechos de maternidad y paternidad, la conciliación entre vida profesional, familiar y personal, los derechos de la personalidad, la integración de personas con discapacidad y con capacidades reducidas. Con respecto a las prácticas laborales, hacen hincapié en el trabajo infantil, trabajo forzoso, la seguridad personal, jornada laboral, las vacaciones, la protección social, la libertad sindical y negociación colectiva. Y, sin embargo, la movilidad laboral (geográfica y funcional) y el acoso sexual y moral. 


\section{Las Acciones Preventivas para Inhibir el Acoso y las}

\section{Enfermedades en el Lugar de Trabajo}

La importancia de adoptar medidas preventivas para inhibir los diferentes tipos de acoso en el lugar de trabajo es esencial, porque las consecuencias de dicha conducta son extremadamente negativas y graves. Por lo tanto, existe la necesidad urgente de tomar medidas con antelación, a través de la adopción de políticas que inhiben la conducta. Como se ha indicado en otra parte, la intervención de los mecanismos de prevención para proteger la salud mental del trabajador y de los principios de acción preventiva, la LPRL de España tiene importantes principios generales sobre el tema. Todas las medidas que la empresa adoptará para garantizar una protección eficaz contra los riesgos profesionales evaluados, teniendo en cuenta los principios de acción preventiva son, entre otros: adaptar el trabajo a la persona, atenuar el trabajo monótono y repetitivo (art. 15). La implantación y la aplicación de un plan de prevención de riesgos laborales deben integrarse en un sistema de gestión de la empresa e incluir la estructura organizativa, procesos y recursos necesarios para adoptar medidas preventivas $(16,1)$. Con los resultados de la evaluación de riesgos, el empresario debe elaborar un documento escrito: el plan de prevención y este plan será obligatorio para todas las empresas (art. 16.2 y 23.1).

La LOIMH de España designa las medidas preventivas para inhibir el acoso sexual y acoso por razón de sexo en las empresas, específicamente en el artículo 48 de la ley con el título: Medidas específicas para prevenir el acoso sexual y el acoso por razón de sexo en el trabajo. Aquí la ley tras sabidamente los códigos de buenas prácticas que son herramientas esenciales para definir o redefinir las medidas de 
prevención, utilizándolos como suporte con empleados y las partes interesadas de la empresa.

La Guía Explicativa y de Buenas Prácticas para la Detección y Valoración de Comportamientos en Materia de Acoso y Violencia en el Trabajo, Documento Elaborado por el Ministerio del Trabajo e Inmigración de España, subraya que las medidas preventivas son aquellas que la empresa adopta con antelación a la materialización de daños ocasionado a la salud de los trabajadores, y que el propósito de identificación o evaluación como medida de prevención es conocer los causadores futuros de la violencia en el trabajo, para tomar luego medidas para eliminar, evitar o reducir dichos riesgos.

En Brasil, las medidas preventivas en virtud de la ley, sean aplicadas por SESMT y por CIPA, cuyo objetivo es observar e informar las condiciones de riesgos en el lugar de trabajo, con el objetivo de preservar la integridad física de los trabajadores. Sin embargo, estas medidas no son suficientes para evaluar, por ejemplo, un riesgo psicosocial en el lugar de trabajo, que es extremadamente subjetivo como el acoso, el burnout o el estrés laboral. No hay por tanto, ninguna ley o reglamento que se ocupa específicamente de las medidas preventivas o planes para prevenir el acoso en el entorno de trabajo en Brasil.

Antes de anotar algunas acciones que la empresa puede tomar para evitar la violencia, las enfermedades ocasionadas por el ambiente de trabajo y el acoso laboral, es importante decir que los administradores deben estar dispuestos e interesados en que la empresa tenga un entorno de trabajo saludable, debiendo dejar claro y bien definido lo que es la violencia en el trabajo y en lo que consiste el acoso, teniendo profesionales capacitados para rediseñar métodos eficaces de gestión y prevención. 


\section{Evaluación Diagnóstica o Evaluación Interna}

La evaluación es una actividad que se realiza actualmente por varios sectores de la sociedad y en varias áreas. El origen de la evaluación como una actividad profesional, nació en EE.UU. en los años 60. A mediados de los años 70, dos asociaciones profesionales que se formaron en 1984 se fusionaron para formar la conocida e influyente American Evaluation Asociation (Asociación Americana de Evaluación). Los procesos de auditoría y evaluación en las empresas tuvieron su origen en la crisis económica de 1929 que llevó a la redacción de las leyes de 1933, creando la Segurity Exchange Comision (Comisión del Mercado de Valores). A partir de ahí, se desarrolló un nuevo sistema de técnicas, principios y valores que dan forma hoy en día, la calidad de lo dinámico sistema empresarial y financiero. Esto se debe a la implementación de sistemas de garantía de la calidad: auditoría, evaluación, acreditación y certificación.

Los procesos de evaluación son elaborados para ayudar en el desarrollo de empresas y profesionales, donde las sesiones colectivas de feedback son el alma del sistema de mediación del desempeño corporativo. Además del Ciclo Deming o PDCA, algunas empresas hacen uso de programas de gestión profesional. El Banco de Brasil, por ejemplo, tiene un programa de capacitación en gestión del rendimiento y clima organizacional en el que cada seis meses sus funcionarios y servicios son evaluados. En este sentido, podemos ver que la calidad de los servicios está estrechamente relacionada con el trabajo realizado por el empleado, su mejora y desarrollo personal, así como el nivel del clima organizacional. ¿Pero, en verdad, lo qué significa la empresa tener un buen "clima organizacional" o un "buen clima de trabajo"? 
Tomamos nota de que hay varios factores implicados en el concepto de clima organizacional. Algunos autores analizan el clima específico para el desarrollo o la apariencia de algo, como la creatividad, el liderazgo o la motivación. En este trabajo, el clima organizacional debe ser visto como un conjunto de atributos que implican un clima favorable y armonioso, donde la gente ejerce un buen relacionamiento interpersonal. Es cierto que las empresas con clima organizacional inestable, con conflictos, problemas de relación y la falta de comunicación, tienen el potencial para desencadenar procesos de violencia, el acoso y las enfermedades como el estrés laboral y el burnout.

\section{La Evaluación 360 Grados o Evaluación de Múltiples Fuentes}

La Evaluación 360 grados es un diagnóstico realizado por la empresa que tiene resultados feebacks de múltiples fuentes, también conocido como Evaluación de Múltiples Fuentes. El método se utiliza comúnmente en el área de Gestión de Personas y apoya el desarrollo del desempeño profesional, contribuyendo al desarrollo de habilidades y talentos dentro de la empresa. En el proceso, todos los participantes reciben simultáneamente feedbacks estructurados de sus superiores jerárquicos, colegas, subordinados y otros stakeholders. El participante también lleva a cabo una autoevaluación.

Hace falta señalar que caso surja conflictos o dificultades en el clima de trabajo o en la relación interpersonal del equipo en los feedbacks recibidos, será importante que la empresa realice una evaluación cualitativa, debiendo haber una continuación para que los expertos en el área de la gestión de personal o recursos humanos, o incluso sus propios empleados del equipo y superiores, puedan proponer 
mejoras y planificar una acción conjunta estratégica y preventiva para evitar daños mayores, como conductas de acoso o enfermedades en el trabajo. En consecuencia, esperamos que en este ítem, la herramienta presente cuestiones relacionadas con el acoso moral, acoso sexual y acoso por razón de sexo en el ámbito trabajo.

\section{Evaluación en Derechos Humanos}

En los capítulos anteriores, vimos las normas internacionales de Derechos Humanos para las empresas y, dentro de ellos, el Pacto Global, que determina su evaluación periódica a través de la comunicación del progreso. Para que las empresas puedan ser consideradas "notables" deben enviar un informe de sus estrategias en relación a las normas del Pacto, incluidas las iniciativas en materia de Derechos Humanos. Este tipo de herramienta es un diagnóstico que hace la propia empresa y se cuestiona si las normas y las medidas aplicadas hasta la fecha de publicación del documento se han tomado.

De acuerdo con las normas de Derechos Humanos de las empresas de la ONU en su documento "Las Normas de Derechos Humanos de la ONU para Empresas: Hacia la Responsabilidad legal”, establecen los mecanismos de verificación de que las empresas deben adoptar para saber si las normas se cumplen y el compromiso firmado está siendo objeto de gestión; También deben realizar regularmente la autoevaluación, hacer público el informe sobre el cumplimiento de las normas y aplicar planes y medidas correctoras.

Cabe mencionar también, otro importante Documento sobre la evaluación de los Derechos Humanos para las empresas: la Guía de Evaluación y Gestión del Impacto sobre Los Derechos Humanos. Esta Guía ha sido elaborada por el 
International Business Leaders Forum, The Global Compact e International Finance

Corporation. Ella está diseñada para permitir a las compañías de diferentes sectores empresariales hacer una prueba con la práctica en la evaluación de la gestión en Derechos Humanos.

El Instituto Dinamarqués de Derechos Humanos - The Danish Institute for Human Rights \& Business, proyectó una herramienta llamada "Evaluación del cumplimiento de los Derechos Humanos (HRCA). Está proyectada para ayudar a las empresas a detectar posibles violaciones de Derechos Humanos causadas por el impacto de sus actividades, sus empleados, comunidad local y otros interesados. Creemos que las empresas pueden tener una evaluación de Derechos Humanos al menos una vez cada semestre, dependiendo del tamaño de la empresa y el número de empleados. Es importante recordar que el sector de los Recursos Humanos o de Gestión de Personas de la empresa debe tener las herramientas adecuadas para tabular los datos y resultados. Podemos decir que la evaluación es un componente central de la implementación real de la protección de los Derechos Humanos en la empresa.

\section{El Método de Evaluación de los Riesgos Psicosociales}

El Cuestionario Psicosocial de Copenhague (CoPsoQ) fue desarrollado en 2000 por un equipo de investigadores del Instituto Nacional de Salud Laboral de Dinamarca. Se utiliza modelos de Demanda - Soporte y control social, el esfuerzo recompensa y doble presencia. La adaptación para España fue realizada por ISTAS. El método de Evaluación de Riesgos Psicosociales es una herramienta de evaluación orientada a la prevención. 
Este Manual de la Evaluación de Riesgo Psicosociales en el Trabajo del ISTAS justifica el método señalando que la relación entre la organización del trabajo y la salud es evidente; que los efectos de la organización del trabajo son intangibles y no específicos y se manifiestan a través de procesos psicológicos, tales como estrés, incluyendo los diversos factores que pueden afectar la salud tanto física como mental y social de los trabajadores.

Preguntas relacionadas al cuestionario presentan cuestiones que involucran el desgaste emocional, emociones reprimidas, dificultad en la expresión de opiniones, como hacer frente a la influencia de los demás, las opiniones y los órdenes de los compañeros y jefes, el entusiasmo por el trabajo y el compromiso con la empresa. En los conflictos, relaciones interpersonales, la salud mental y cómo el empleado se siente física y emocionalmente. Estos temas distribuidos en forma de preguntas pueden detectar problemas de salud y sus respuestas servirán de base para tomar medidas de acciones preventivas. Además de las evaluaciones y diagnósticos que son acciones preventivas, creemos que existen otros recursos que las organizaciones pueden utilizar para hacer el lugar de trabajo más armonioso, sano y libre de riesgos que puedan afectar la salud del trabajador, evitando el acoso y la violencia como, por ejemplo, relajación o gimnasia laboral. Por lo tanto, una práctica empresarial responsable, es aquella que lleva a cabo evaluaciones periódicas y adopta iniciativas como estas, a partir de acciones, estrategias sencillas y con direcciones muy claras. Ciertamente, la prevención y las acciones positivas, de manera significativa reducen cualquier tipo de acoso, las enfermedades y la violencia en el trabajo.

\subsection{El Papel de los Sindicatos y de los Órganos de Protección del}

\section{Trabajador}


En Brasil, algunas entidades, como el Sindicato de los Bancarios, ya han empezado a actuar en forma de campañas para denunciar, según ellos, el enemigo no siempre visible, pero siempre constante en la categoría - el acoso moral. Por lo general, estas movilizaciones se centran en la sensibilización sobre el acoso y la violencia en el trabajo. Proporcionan las reuniones donde son discutidas medidas para combatir la práctica, responder preguntas y estimular la denuncia. Cartillas temáticas son confeccionadas y una serie de manifestaciones y acciones de protesto son organizadas.

En este sentido, el sindicato es un órgano muy importante en la lucha contra la violencia y el terror psicológico en el trabajo. A través del uso del marketing social, material promocional, folletos, campañas, declaraciones de impacto, sitios web, grupos de discusión y seminarios sobre el acoso moral, las entidades contribuyen para las informaciones al respecto del tema llegan a todos, inclusive de la sociedad, concientizándolos contra la conducta del acoso en el trabajo.

Sin embargo, en estas acciones, no se mencionan el acoso sexual, acoso por razón de sexo o, tampoco, las enfermedades laborales como el estrés y el burnout. Es una brecha enorme en relación a la salud de los trabajadores y los riesgos psicosociales en el ámbito trabajo. Por lo tanto, además de estas medidas, es importante que los órganos de protección de los trabajadores realicen cursos de capacitación para sus dirigentes sindicales en el área de seguridad y salud laboral, proporcionando datos sobre los riesgos psicosociales que el trabajador está sujeto en el ambiente de trabajo, formulando políticas de prevención e intervención a través de la acción sindical.

No cabe duda de que el papel de las entidades sindicales es fundamental en la prevención, reducción y / o eliminación de los riesgos en el lugar de trabajo y cualquier persona que ocupe un puesto de trabajo remunerado tiene derecho a la 
protección de su salud y seguridad en el trabajo. Subrayamos que es a través de las acciones antes mencionadas, de los convenios, de los acuerdos y de las negociaciones colectivas que los sindicatos pueden reivindicar mejoras en las condiciones de trabajo, acerca de la violencia, del acoso y de la enfermedad laboral, con la inclusión de cláusulas destinadas a protección de los Derechos Humanos y fundamentales de los trabajadores. 


\section{INTRODUÇÃO}

Esse trabalho apresenta-se estruturado em três capítulos. No primeiro, discorremos sobre os documentos internacionais de proteção à pessoa, perfazendo um breve histórico desde os primeiros documentos ingleses do século XIII e XVII que já abordavam algumas liberdades e direitos, até a Declaração dos Direitos Humanos de 1948, que inspirou e ainda inspira Pactos, Acordos e Convenções internacionais no que respeita os direitos fundamentais, proporcionando a ampliação das discussões no âmbito do Direito Internacional dos Direitos Humanos. Versamos sobre a Organização Internacional do Trabalho (OIT), suas Recomendações e Convenções relativas aos direitos fundamentais do trabalhador, a importância da Declaração Sociolaboral do Mercado Comum do Sul (Mercosul) prevendo a não-discriminação no emprego e a recomendação para que os países integrantes do bloco adotem medidas para a educação, readaptação e formação profissional.

Destacamos alguns instrumentos de proteção dos direitos fundamentais do trabalhador no âmbito Europeu, como as Diretivas relativas ao princípio de igualdade de tratamento entre homens e mulheres e a não discriminação no emprego seja ela direta ou indireta. Em seguida, abordamos os direitos fundamentais do trabalhador na ordem jurídica brasileira e espanhola, destacando as suas respectivas Constituições e outros mecanismos de proteção. Ao final do capítulo, tratamos da proteção à segurança e à saúde do trabalhador no Brasil e na Espanha e os meios que os dois países utilizam para fazer valer tais direitos, citando as responsabilidades das empresas e das instituições. 
O segundo capítulo versa sobre os riscos laborais e psicossociais, as enfermidades mais comuns causadas por um ambiente laboral hostil e conflituoso, como o estresse e o burnout. Conceituamos a violência e suas mais variadas formas, como a violência moral e/ou psicológica e que se descortina através dos diferentes tipos de assédio. Dessa forma, tratamos primeiramente do assédio moral, os conceitos de alguns autores e suas características, a discussão no Brasil sobre o tema, os tipos e quem são de fato, o agressor e a vítima. Em seguida, abordamos o assédio sexual nas organizações e o assédio por razão de sexo, que tipifica a desigualdade no ambiente de trabalho, ainda muito frequente. E por último, as consequências dessas condutas para o trabalhador, para a empresa e seus efeitos na sociedade.

No terceiro capítulo tratamos da Gestão Empresarial e dos Direitos Humanos, o conceito da ética no mundo corporativo, os códigos de conduta empresariais e o que eles revelam em matéria de responsabilidade social e direitos fundamentais do trabalhador. Em seguida trouxemos um ensaio sobre os Direitos Humanos, algumas definições, características e classificação. No mesmo contexto, discutimos como se dá a relação entre Direitos Humanos e a Responsabilidade Social Empresarial e a efetivação desses direitos no ambiente laboral.

Para tanto, evidenciamos as Diretrizes para as Empresas Multinacionais da Organização para a Cooperação e Desenvolvimento Econômico (OCDE), a Declaração Tripartite de Princípios sobre Empresas Multinacionais e a Política Social da Organização Internacional do Trabalho (OIT), o Pacto Global e as Normas de Direitos Humanos para as Empresas da Organização das Nações Unidas (ONU), que tratam sobretudo da responsabilidade sócio ambiental das empresas e dos direitos 
fundamentais no trabalho. Além disso, apontamos algumas iniciativas da sociedade civil que versam sobre a mesma matéria.

E por fim, destacamos a necessidade de as empresas estabelecerem ações preventivas para inibir as enfermidades, o assédio e a violência no ambiente de trabalho. Abordamos a Avaliação em Direitos Humanos no âmbito da empresa, como uma ação preventiva e uma ferramenta de gestão, uma vez que ela pode diagnosticar e prevenir as causas de condutas que vão contra tais direitos, discutindo papel dos sindicatos a respeito do tema. 


\section{JUSTIFICATIVA E RELEVÂNCIA DO ESTUDO}

Atualmente, as empresas nunca estiveram tão atentas à concorrência e a competitividade, fatores como a globalização, a terceirização, a automação e a flexibilidade dos serviços são importantes na busca desses itens. Dessa maneira, o trabalhador deve adaptar-se a essas novas exigências, sendo polivalente e estando em constante qualificação e atualização profissional. Essas exigências impostas e as cobranças constantes que ocorrem no ambiente de trabalho, faz com que o trabalhador apresente quadros de enfermidades, fazendo com que seu desempenho profissional seja insuficiente, levando-o a insatisfação, desencadeando muitas vezes um ambiente de trabalho hostil e conflituoso, tendo como consequência a violência e o assedio no ambiente de trabalho. Condutas essas que ferem a dignidade do trabalhador e atentam contra seu direitos fundamentais.

No Brasil o tema que aborda os riscos psicossociais e as enfermidades que podem ser causadas pelo ambiente laboral é pouco difundido, a legislação é escassa e a bibliografia é quase inexistente. Na Espanha a discussão sobre as ações preventivas para inibir essas condutas são discutidas, porém não oferece uma legislação específica. Dessa forma, acreditamos que o tema é relevante tanto para as empresas como para o direto do trabalho. As avaliações que a empresa pode realizar propostas aqui, como medidas preventivas para inibir a violência e o assédio no ambiente de trabalho, são inovadoras e ao adotá-las as empresas melhoram seu processo de gestão, protegendo a dignidade e os direitos fundamentais dos seus trabalhadores. 
Pensando nesses fatores que nasceu a motivação para a realização desse estudo, tendo como base nossa formação pedagógica aliada com a experiência bancária. Acreditamos que a prática do pedagogo na empresa vai além do treinamento e da aprendizagem para a qualificação profissional, ele é um dos profissionais da área de Gestão de Pessoas que contribui na elaboração de ferramentas e de ações preventivas para prevenir a violência e o assédio no trabalho, como a Avaliação Diagnóstica, a Avaliação 360 graus e a Avaliação em Direitos Humanos. O pedagogo também deve conceber uma forma de trabalho mais humana, identificando nos trabalhadores habilidades e elevando seu nível produtivo, melhorando suas condições de trabalho e propiciando um ambiente de trabalho estável e saudável. Dessa forma a pedagogia está intimamente ligada ao labor humano. 


\section{METODOLOGIA DA PESQUISA}

Considerando a necessidade de definir o método que irá orientar o raciocino lógico da pesquisa, optaremos por utilizar o método dedutivo. Para DESCARTES, O método dedutivo é um método lógico que pressupõe que existem verdades gerais já afirmadas e que servem de base (premissas) para se chegar através dele a conhecimentos novos. A dedução consiste em um recurso metodológico em que a racionalização ou a combinação de idéias em sentido interpretativo é mais importante que a experimentação.

Dentro disso, o método dedutivo pressupõe que apenas a razão pode conduzir ao conhecimento verdadeiro. Partindo de princípios reconhecidos como verdadeiros e inquestionáveis (premissa maior), onde o pesquisador estabelece relações com uma proposição particular (premissa menor) para, a partir do raciocínio lógico, chegar a verdade daquilo que propõe que é a conclusão. Portanto, a premissa maior, é considerar que os riscos laborais por assédio e violência no ambiente de trabalho são uma conduta presente na rotina das empresas, e a premissa menor, é verificar se as ações preventivas realizadas pelas empresas podem ser consideradas ferramentas capazes de inibir e prevenir tais condutas.

Trabalhamos o seguinte problema: Quais as ações preventivas que as empresas podem utilizar para inibir os riscos laborais por assédio e violência no ambiente de trabalho? O objetivo geral da pesquisa consiste em compreender os princípios relativos à dignidade do trabalhador expressos na ordem jurídica internacional, identificando como estão positivados no Brasil e da Espanha no rol dos 
direitos fundamentais, analisando os documentos internacionais no que respeita o direito de não ser assediado e que medidas preventivas as empresas podem utilizar para inibir o assédio e a violência no ambiente de trabalho.

Definido o método de abordagem do problema da pesquisa, expressadas aqui, pelos objetivos específicos, desenhados nos capítulos da tese, a saber:

a) Compreender os princípios relativos à dignidade do trabalhador expressos na ordem jurídica internacional, identificando como estão positivados na legislação do Brasil e da Espanha no rol dos direitos fundamentais;

b) Conhecer as enfermidades decorrentes do ambiente de trabalho, suas causas e consequências, compreendendo o processo do assédio como um risco laboral e psicossocial e as conseqüências dessa conduta para o trabalhador e para a empresa;

c) Visualizar a necessidade das empresas trabalharem na proteção dos Direitos da pessoa humana, analisando as iniciativas e os documentos internacionais de proteção que recomendam às organizações empresariais a assumirem o compromisso de agir em prol do respeito aos Direitos Humanos e as ações preventivas utilizadas como ferramentas para inibir a violência e o assédio no ambiente de trabalho.

A utilização do método de abordagem do problema de forma dedutiva justifica-se porque a pesquisa se inicia verificando o significado da violência, do assédio, os tipos, a prevenção, as pessoas envolvidas e a caracterização desse tipo de delito, tendo como foco o mundo do trabalho. Após, estudamos a responsabilidade social e a ética empresarial expressas em documentos como os códigos de conduta e ética das empresas. Analisamos as diretrizes e normas internacionais de Direitos Humanos para as empresas de organizações como a OCDE, OIT e ONU e também 
outras iniciativas da sociedade civil que tem o objetivo de buscar inibir o assédio. E por fim, as ações preventivas capazes de prevenir a violência e o assédio no ambiente de trabalho e o papel dos sindicatos nessa tarefa.

O método de procedimento do problema consiste em especificar a forma como iremos trabalhar a coleta dos dados necessários a configuração da pesquisa. Diante disso, a proposta foi de trabalhar a pesquisa bibliográfica através da utilização de fontes primárias tais como leis, reais decretos, tratados, acordos, diretrizes e pactos internacionais e a pesquisa documental, ou seja, as fontes secundárias, livros, revistas, cartilhas, informes, artigos científicos, teses e sites da internet .

O tema Direitos Humanos do trabalhador exige o enfoque interdisciplinar, envolvendo áreas do direito como o Direito do Trabalho, o Direito Internacional e o Direito Internacional dos Direitos Humanos. Além disso, quando enfocamos as ações preventivas para inibir as enfermidades e as condutas de assédio ou de violência no ambiente laboral, enfrentamos as áreas da Administração de Empresas, da Administração de Recursos Humanos e de Gestão de Pessoas e, ainda, nessas duas últimas incluem-se as áreas da Psicologia e da Pedagogia. Vale destacar que, o tema é amplo requerendo uma abordagem geral, pois o escopo teórico é composto por uma diversidade de fontes pesquisadas.

Portanto, não aprofundamos o estudo dos mecanismos jurídicos para a proteção dos direitos fundamentais dos trabalhadores, como por exemplo, as demandas trabalhistas e tampouco o tratamento de enfermidades laborais. Optamos por tratar dos fatos que antecedem a violência e o assédio no ambiente de trabalho, que são as ações preventivas no âmbito das empresas, e não com fatos ocorridos a posteriori dessas condutas, já que estes merecem um estudo à parte. 


\section{CAPÍTULO I}

\section{O DIREITO À DIGNIDADE DO TRABALHADOR}

\subsection{Na Ordem Jurídica Internacional}

A proposta desse capítulo é enfocar os princípios relativos à dignidade do trabalhador expressos na ordem jurídica internacional, identificando como estão positivados nos ordenamentos jurídicos do Brasil e da Espanha no rol dos direitos fundamentais. Dedicaremos primeiramente, um breve histórico sobre os diretos fundamentais do homem, cuja evolução nos ajudarão a entender o conteúdo expresso nos documentos mais importantes sobre a matéria.

$\mathrm{Na}$ Inglaterra, elaboraram-se as Cartas e Estatutos de direitos fundamentais, como a Carta Magna de João sem Terra de 1215, reconhecendo em seu texto, direitos fundamentais como a liberdade de religião, o julgamento popular de crimes contra a vida, entre outros. Contudo, esse documento excluía os homens não livres, como os escravos. Para NOBLET ${ }^{1}$, a referida carta era uma carta feudal, feita para proteger os privilégios dos barões e dos homens livres. Sua preocupação principal era proteger os interesses econômicos dos barões e dos comerciantes, sendo que a proteção da dignidade era para poucos privilegiados da época.

\footnotetext{
${ }^{1}$ A democracia Inglesa, p.28. Apud: SILVA, José Afonso. Curso de Direito Constitucional Positivo. $10^{\mathrm{a}}$ edição, São Paulo: Malheiros, 1994, (p.150).
} 
Ainda, na Inglaterra, a Petition of Rights de 1628, documento elaborado pelo Parlamento Inglês, veio ratificar a Carta Magna de 1215, pedindo atenção especial aos direitos e liberdades já reconhecidos no documento anterior. Outro documento de igual importância foi o Bill of Rights - Declaração de Direitos que decorreu da revolução de 1688, dando supremacia ao Parlamento e consolidando a monarquia constitucional inglesa. $O$ Petition of Rights constituiu um meio de concessões recíprocas entre o Parlamento inglês e o Rei, firmado com o intuito de reiterar a ordem monárquica de obediência aos direitos e liberdades. Já o Bill of Rights, era uma lista de direitos que previa a liberdade de expressão e de imprensa, a liberdade política e a tolerância religiosa, a proteção contra o exército permanente e o habeas corpus. O predomínio da burguesia no Parlamento criou as condições necessárias para o avanço da industrialização e do capitalismo no decorrer dos séculos XVIII e XIX.

Em sentido moderno, a primeira Declaração que aporta os direitos fundamentais e que, segundo alguns autores constitui o registro do nascimento dos Direitos Humanos na história, foi a Declaração do Bom Povo da Virginia, que era uma das colônias inglesas da época (1776), inspirada nas idéias de três filósofos iluministas: Locke, Rousseau e Montesquieu, que foram os responsáveis pela elaboração do escopo político do Estado Moderno, ou seja, do princípio da legalidade, da separação dos poderes e da democracia. A Declaração preocupava-se com a limitação do poder e no estabelecimento de um governo democrático. Ela expressava com clareza os fundamentos do regime democrático, o reconhecimento dos direitos inatos da pessoa humana e o princípio de que o poder emana do povo. Firmava também, o princípio de igualdade de todos perante a lei ${ }^{2}$.

\footnotetext{
${ }^{2}$ Essa declaração deu as bases dos direitos dos homens como em seu artigo $\mathbf{1}^{\mathbf{o}}$, que diz que todos os homens nascem igualmente livres e independentes, têm direitos certos, essenciais e naturais dos quais não
} 
A Declaração dos Direitos do Homem e do Cidadão de 1789, aprovada no auge da Revolução Francesa, para PEREZ LUÑO³ é um texto de caráter universal de direitos consagrados, pelo seu fundamento racional e cuja validez se considera absoluta. Os direitos que correspondiam ao homem eram os de liberdade, de propriedade, de segurança e de resistência à opressão. Essa Declaração formou parte da primeira Constituição francesa de 1791, e, depois, a de 1793, chamada de Jacobina que trazia em seu conteúdo o reconhecimento do direito ao trabalho, a proteção frente à pobreza e à educação.

Até então, esses Documentos anunciavam apenas as garantias formais das liberdades (direitos de primeira geração). No século XIX, palco da Revolução Industrial, alavancou-se um crescimento econômico notório, contudo, às custas de uma parte da população - os trabalhadores que, sem as mínimas condições básicas não tinham limitação da jornada de trabalho, férias ou descanso regular - surgiu uma série de problemas sociais e as classes operárias começaram a se unir e reivindicar seus direitos. Foi então que, em 1948, Karl Marx escreveu o Manifesto Comunista, um dos Documentos políticos mais importantes na crítica socialista ao regime liberal burguês,

podem, por nenhum contrato, privar nem despojar sua posteridade: tais são o direito de gozar a vida e a liberdade com os meios de adquirir e possuir propriedades, de procurar obter a felicidade e a segurança. Nesse sentido, vale citar na íntegra alguns artigos: Artigo $2^{\circ}$ - Toda a autoridade pertence ao povo e por conseqüência dela se emana; os magistrados são os seus mandatários, seus servidores, responsáveis perante ele em qualquer tempo. Artigo $3^{\circ}$ - O governo é ou deve ser instituído para o bem comum, para a proteção e segurança do povo, da nação ou da comunidade Artigo $5^{\circ}$ - O poder legislativo e o poder executivo do estado devem ser distintos e separados da autoridade judiciária; e a fim de que também eles de suportar os encargos do povo e deles participar possa ser reprimido todo o desejo de opressão dos membros dos dois primeiros devem estes em tempo determinado, voltar a vida privada, reentrar no corpo da comunidade de onde foram originariamente tirados; os lugares vagos deverão ser preenchidos pôr eleições, freqüientes, certas e regulares. Artigo $6^{\circ}$ - As eleições dos membros que devem representar 0 povo nas assembléias serão livres; e todo indivíduo que demonstre interesse permanente e o consequente zelo pelo bem geral da comunidade tem direito geral ao sufrágio. Artigo $7^{\circ}$ - Nenhuma parte da propriedade de um vassalo pode ser tomada, nem empregada para uso público, sem seu próprio consentimento, ou de seus representantes legítimos; e o povo só está obrigado pelas leis, da forma pôr ele consentida para o bem comum. Artigo $8^{\circ}$ - Todo o poder de deferir as leis ou de embaraçar a sua execução, qualquer que seja a autoridade, sem o consentimento dos representantes do povo, é um atentado aos seus direitos e não tem cabimento.

${ }^{3}$ PEREZ LUÑO. Los Derechos Fundamentales. $9^{a}$ edición, Madrid: Tecnos, 2007, (pp.36-37). 
sugerindo um curso de ação para uma revolução socialista através da tomada do poder pelos proletários. Nesse momento, outro Documento foi editado pela Igreja Católica que, até então, tinha se mostrado neutra em relação aos conflitos dos trabalhadores e seus patrões: a Encíclica Papal Rerum Novarum, escrita pelo Papa Leão XIII em 1891. A Encíclica criticava as condições de vida dos trabalhadores e apoiava o reconhecimento de alguns direitos trabalhistas instituindo condições míninas de proteção ao trabalhador, como um regime de trabalho adequado, a proteção em relação a idade, ao sexo e o direito a um salário justo.

A Constituição Mexicana de 1917 e a Constituição Alemã de Weimar de 1919 foram as pioneiras em positivar os direitos econômicos, sociais e culturais. A Carta Mexicana sistematizou os direitos sociais do homem em especial no seu artigo 123 dedicado ao trabalho e a previdência social, prevendo que "toda persona tiene derecho al trabajo digno y socialmente útil; al efecto, se promoverán la creación de empleos y la organización social para el trabajo, conforme a la ley. Já a alemã, abriu no seu livro II o Título: Dos Direitos e de Deveres fundamentais dos Alemães, incluindo os Direitos da pessoa individual, da vida social e religiosa, da educação e escola e da vida econômica ${ }^{4}$. Esta Constituição, exerceu uma maior influência na história do constitucionalismo pós primeira guerra mundial, pois, durante muito tempo, foi o texto inspirador das Cartas constitucionais que tentaram conjugar em seus sistemas de direitos fundamentais as liberdades com os direitos econômicos, sociais e culturais ${ }^{5}$.

O reconhecimento internacional desses direitos, trouxe a obrigação correspondente aos Estados em positivá-los, respeitá-los e garanti-los. A resolução adotada em 1929, pelo Instituto de Direito Internacional declarou ser dever do Estado

\footnotetext{
${ }^{4}$ Disponível em:< http://dhnet.org.br/direitos/anthist/mexico/const1917.htm>. Acesso em 23.09.2009.

${ }^{5}$ Op. Cit. Nota 03, (p.40).
} 
"reconhecer a todo indivíduo o mesmo direito à vida, à liberdade, à propriedade, e conceder a todos o seu território, plena e inteira proteção desse direito, sem distinção de nacionalidade, sexo, raça, de língua ou religião." E, ainda, previu que incumbia ao Estado proteger os direitos internacionais do homem. Dentro disso, a Carta das Nações Unidas de 1945 proferida pela Organização das Nações Unidas (ONU), insistiu na existência desses direitos e liberdades fundamentais e, consequentemente, a Declaração Universal dos Direitos do Homem definiu-os ${ }^{6}$.

A Declaração Universal dos Direitos do Homem com seus trinta artigos e um preâmbulo, reconhece claramente a dignidade da pessoa humana, o ideal democrático, o direito de resistência à opressão. No que se refere ao trabalho, do artigo 22 ao 28, o documento dá relevância aos direitos sociais do homem, prevendo o direito ao trabalho, à escolha do trabalho, as condições satisfatórias de trabalho e a proteção contra o desemprego. Ainda afirma que o trabalhador tem direito a um salário digno, a liberdade sindical, a limitação razoável da duração da jornada de trabalho e ao descanso remunerado.

Dentre os Documentos referidos, nos quais os Estados signatários comprometeram-se a respeitar e garantir o respeito universal e efetivo dos direitos fundamentais do homem, são expressivos também, o Pacto Internacional de Direitos Civis e Politicos (PIDCP) e o Pacto Internacional de Direitos Econômicos, Sociais e Culturais (PIDESC), ambos aprovados pela Assembléia Geral da ONU em $1966^{7}$. É interessante destacar, que a adoção desses Pactos no plano internacional, demonstram a

\footnotetext{
${ }^{6} \mathrm{O}$ direito à liberdade individual do homem e à proteção de sua pessoa estão proclamados no art. $1^{\circ}$ da Declaração Americana dos Direitos e Deveres do Homem: "Todo ser humano tem direito à vida, à liberdade e a segurança de sua pessoa." e no art. $3^{\circ}$ da Declaração Universal dos Direitos do Homem: "Todo o indivíduo tem direito à vida, à liberdade e à segurança pessoal."

${ }^{7}$ Esses documentos podem ser consultados na página oficial da ONU: <http://www2.ohchr.org/spanish/law/index.htm>.
} 
intenção dos Estados em estabelecer obrigações de alcance diferente em relação a cada categoria de direito. O PIDCP, no seu artigo 2.2, consagra incondicionalmente a obrigação de adotar medidas para fazer frente aos direitos previstos. No caso do PIDESC, o artigo 2.1 traz essa obrigação e refere-se aos recursos a serem utilizados pelos Estados para a realização progressiva desses direitos. Destaca-se ainda, a referência do primeiro Documento em sua parte IV, a criação do Comitê de Direitos Humanos que deve receber as comunicações dos Estados partes sobre outros Estados que não cumprirem as determinações firmadas no Pacto. Em relação ao segundo Documento, em sua parte IV, há o estabelecimento de um sistema de informes para que se possa acompanhar o progresso da implementação dos direitos firmados. Esses direitos são postos em prática e fiscalizados e os referidos Documentos discutidos e analisados no âmbito interno dos Estados signatários, com a possibilidade de denunciar violações do Estado ante os órgãos internacionais criados por esses mecanismos, sendo a instância internacional utilizada de forma subsidiária.

Sobre o trabalho forçado, a ausência da escravidão e a defesa do trabalho digno é aclarado no artigo $8^{\circ}$ do PIDCP e no artigo $6^{\circ}$ do PIDESC $^{8}$. A respeito da liberdade sindical, destacam-se os artigos 22 do PIDCP e $8^{\circ}$ do PIDESC. ${ }^{9}$ Sobre a não-

\footnotetext{
${ }^{8}$ Art. 8 - 1. Ninguém poderá ser submetido à escravidão; e o tráfico de escravos, em todas as suas formas, ficam proibidos. 2. Ninguém poderá ser submetido à servidão. 3. a) ninguém poderá ser obrigado a executar trabalhos forçados ou obrigatórios; b) a alínea "a" do presente parágrafo não poderá ser interpretado no sentido de proibir, nos países em que certos crimes sejam punidos com prisão e trabalho forçados, o cumprimento de uma pena de trabalhos forçados, imposta por um tribunal competente; c) para os efeitos do presente parágrafo, não serão considerados trabalhos forçados ou obrigatórios: qualquer trabalho ou serviço, não previsto na alínea "b", normalmente exigido de um indivíduo que tenha sido encarcerado em cumprimento de decisão judicial ou que, tendo sido objeto de tal decisão, ache-se em liberdade condicional; qualquer serviço de caráter militar e, nos países em que se admite a isenção por motivo de consciência, qualquer serviço nacional que a lei venha a exigir daqueles que se oponham ao serviço militar por motivo de consciência; qualquer serviço exigido em casos de emergência ou de calamidade que ameacem o bem-estar da comunidade; qualquer trabalho ou serviço que faça parte das obrigações cívicas normais. Art. $6^{\circ}$ - 1. Os Estados-partes no presente Pacto reconhecem o direito de toda pessoa de ter a possibilidade de ganhar a vida mediante um trabalho livremente escolhido ou aceito e tomarão medidas apropriadas para salvaguardar esse direito.

${ }^{9}$ Art. 22 - 1. Toda pessoa terá o direito de associar-se livremente a outras, inclusive o direito de constituir sindicatos e de a eles filiar-se, para proteção de seus interesses. 2. O exercício desse direito estará sujeito
} 
discriminação os artigos $2^{\circ}$ do PIDCP e 26 e $27^{10}$ igualmente, e no PIDESC o artigo $7^{\mathrm{o} 11}$ :

Na América do Sul, um Documento anterior a Declaração Universal dos

Direitos Humanos, aprovado em 1948, oito meses antes dela foi a Declaração

Americana dos Direitos e Deveres do Homem que trouxe uma série de direitos sociais e

apenas às restrições previstas em lei e que se façam necessárias, em uma sociedade democrática, ao interesse da segurança nacional, da segurança e da ordem públicas, ou para proteger a saúde ou a moral públicas ou os direitos e as liberdades das demais pessoas. O presente artigo não impedirá que se submeta a restrições legais o exercício desses direitos por membros das forças armadas e da polícia. 3. Nenhuma das disposições do presente artigo permitirá que os Estados-partes, na Convenção de 1948, da Organização Internacional do Trabalho, relativa à liberdade sindical e à proteção do direito sindical, venham a adotar medidas legislativas que restrinjam - ou a aplicar a lei de maneira a restringir - as garantias previstas na referida Convenção. Art. 8 - - 1. Os Estados-partes no presente Pacto comprometem-se a garantir: a) $\mathrm{O}$ direito de toda pessoa de fundar com outras sindicatos e de filiar-se ao sindicato de sua escolha, sujeitando-se unicamente aos estatutos da organização interessada, com o objetivo de promover e de proteger seus interesses econômicos e sociais. O exercício desse direito só poderá ser objeto das restrições previstas em lei e que sejam necessárias, em uma sociedade democrática, ao interesse da segurança nacional ou da ordem pública ou para proteger os direitos e as liberdades alheias; b) O direito dos sindicatos de formar federações ou confederações nacionais, e o direito destas de formar organizações sindicais internacionais ou de filiar-se às mesmas; c) O direito dos sindicatos de exercer livremente suas atividades, sem quaisquer limitações além daquelas previstas em lei e que sejam necessárias, em uma sociedade democrática, ao interesse da segurança nacional ou da ordem pública ou para proteger os direitos e as liberdades das demais pessoas; d) $\mathrm{O}$ direito de greve, exercido em conformidade com as leis de cada país. 2. O presente artigo não impedirá que se submeta a restrições legais o exercício desses direitos pelos membros das forças armadas, da polícia ou da administração pública. 3. Nenhuma das disposições do presente artigo permitirá que os Estados-partes na Convenção de 1948 da Organização Internacional do Trabalho, relativa à liberdade sindical e à proteção do direito sindical, venham a adotar medidas legislativas que restrinjam - ou a aplicar a lei de maneira a restringir as garantias previstas na referida Convenção.

${ }^{10}$ Art. $2^{\mathbf{0}}-1$. Os Estados-partes no presente Pacto comprometem-se a garantir a todos os indivíduos que se encontrem em seu território e que estejam sujeitos à sua jurisdição os direitos reconhecidos no atual Pacto, sem discriminação alguma por motivo de raça, cor, sexo, língua, religião, opinião política ou de qualquer outra natureza, origem nacional ou social, situação econômica, nascimento ou qualquer outra situação. Art. 26 - Todas as pessoas são iguais perante a lei e têm direito, sem discriminação alguma, a igual proteção da lei. A este respeito, a lei deverá proibir qualquer forma de discriminação e garantir a todas as pessoas proteção igual e eficaz contra qualquer discriminação por motivo de raça, cor, sexo, língua, religião, opinião política ou de outra natureza, origem nacional ou social, situação econômica, nascimento ou qualquer outra situação. Art. 27 - Nos estados em que haja minorias étnicas, religiosas ou lingüísticas, as pessoas pertencentes a essas minorias não poderão ser privadas do direito de ter, conjuntamente com outros membros de seu grupo, sua própria vida cultural, de professar e praticar sua própria religião e usar sua própria língua.

${ }^{11}$ Art. 70 - Os Estados-partes no presente Pacto reconhecem o direito de toda pessoa de gozar de condições de trabalho justas e favoráveis, que assegurem especialmente: a) Uma remuneração que proporcione, no mínimo, a todos os trabalhadores: i) um salário eqüitativo e uma remuneração igual por um trabalho de igual valor, sem qualquer distinção; em particular, as mulheres deverão ter a garantia de condições de trabalho não inferiores às dos homens e perceber a mesma remuneração que eles, por trabalho igual; ii) uma existência decente para eles e suas famílias, em conformidade com as disposições do presente Pacto; b) Condições de trabalho seguras e higiênicas; A igual oportunidade para todos de serem promovidos, em seu trabalho, à categoria superior que lhes corresponda, sem outras considerações que as de tempo, de trabalho e de capacidade; d) O descanso, o lazer, a limitação razoável das horas de trabalho e férias periódicas remuneradas, assim como a remuneração dos feriados. 
individuais para a pessoa humana. A Declaração americana foi reconhecida internacionalmente e aprovada pela IX Conferência Internacional Americana em Bogotá, neste mesmo ato, também se aprovou a Carta Internacional Americana de Garantias Sociais, prevendo os direitos sociais do homem americano, conhecida como Pacto de San Jose da Costa Rica, em 1969. A Carta, institucionalizou a Comissão Interamericana de Direitos Humanos em 1978, e foi ratificada pelo Brasil somente em 1992. Nesse sentido, AFONSO DA SILVA ${ }^{12}$, afirma que a ineficácia destes documentos interamercianos está retratada na tragédia dos países latinoamericanos submetidos ao desrespeito aos mais elementares direitos da pessoa humana, embora a Constituição brasileira de 1988 demonstre uma reação democrática em relação a isso, conforme discutiremos no próximo item.

A Declaração Universal dos Direitos Humanos de 1948 é o documento inspirador de vários Pactos, Acordos e Convenções internacionais no que respeita aos direitos fundamentais da pessoa humana, proporcionando a ampliação das discussões no âmbito do Direito Internacional dos Direitos Humanos. Aqui, é interessante destacar o trabalho de BARZOTTO ${ }^{13}$ quando expressa que os direitos humanos estão postos em um ponto médio entre os valores jurídicos e os direitos fundamentais e, quando seu reconhecimento ocorre, mediante uma determinação de conteúdos em uma ordem jurídica, esses direitos humanos se convertem em direitos fundamentais, ou seja, direitos humanos positivados. Para PEREZ LUÑO ${ }^{14}$,

Los términos derechos humanos y derechos fundamentales, son utilizados muchas veces, como sinónimos. Sin embargo, no han

\footnotetext{
${ }^{12}$ SILVA, José Afonso. Curso de Direito Constitucional Positivo. 10a edição, São Paulo: Malheiros, 1994, (p.165).

${ }^{13}$ BARZOTTO, Luciane Cardoso. Direitos Humanos e Trabalhadores - Atividade Normativa da Organização Internacional do Trabalho e os Limites do Direito Internacional do Trabalho. Porto Alegre: Livraria do Advogado, 2007, (p.18).

${ }^{14}$ Op. Cit. Nota 03, (p.44).
} 
faltado tentativas doctrinales encaminadas a explicar el respectivo alcance de ambas expresiones. Así (...) derechos fundamentales para designar los derechos positivados a nivel interno (...) derechos humanos sería la más usual para denominar los derechos naturales positivados en las declaraciones y convenciones internacionales.

Então, quando falamos em dignidade da pessoa humana, estamos englobando o conceito de direitos fundamentais - direitos humanos positivados internamente nas Constituições dos Estados. E, ao abordarmos a expressão direitos humanos, nos referimos ao plano das Declarações e das Convenções internacionais, que constituem um critério de unificação de todos os direitos destinados aos homens. A mesma idéia tem HUMENHUK $^{15}$, ao afirmar que os direitos fundamentais são considerados os direitos do ser humano, reconhecidos e positivados na esfera do direito constitucional positivo de determinados Estados. A expressão direitos humanos, por sua vez, guardaria relação com os Documentos de direito internacional, porque, refere-se àquelas posições jurídicas que são reconhecidas ao ser humano como tal, independentemente de sua vinculação com determinada ordem constitucional e que, buscam a validade universal, independentemente dos povos e do tempo da sua vigência. Portanto, tem um inequívoco caráter supranacional.

Neste trabalho, optamos por utilizar a expressão Direitos Humanos dos trabalhadores, quando discutimos as Declarações, Documentos, Pactos e as Convenções internacionais sobre o trabalho, porque, em toda a bibliografia pesquisada até então, a terminologia Direitos Humanos é corrente. Ademais, consideramos que a dignidade do trabalhador deve ser universal, pois, só através do trabalho é que o homem garante a sua subsistência e, com os frutos dele advindo, poderá ter acesso aos demais direitos. Assim, os valores referentes ao trabalho que a Declaração Universal dos

\footnotetext{
${ }^{15}$ HUMENHUK, Hewerstton. $O$ direito à saúde no Brasil e a teoria dos direitos fundamentais. Disponível em: <http://jus2.uol.com.br/doutrina/texto.asp?id=4839>. Acesso em: 27.08. 2009.
} 
Direitos Humanos abriga são: a dignidade da pessoa humana, que implica na concretização de outros valores, como a dignificação do trabalho, prevista nos artigos XXIII, XXIV e XXV ${ }^{16}$.

A Conferência das Nações Unidas sobre o meio ambiente humano, elaborada em 1972, conhecida como Declaração de Estocolmo, atenta para a necessidade de se estabelecer um critério e princípios comuns que ofereçam aos povos do mundo, inspiração e guia para preservar e melhorar o meio ambiente humano, trazendo uma contribuição importante relativa ao meio ambiente laboral. Ela prevê que o homem tem o direito fundamental a liberdade, a igualdade e ao desfrute das condições de vida adequadas, em um meio ambiente de qualidade tal, que lhe permita levar uma vida digna e gozar do bem estar, tendo ainda, a obrigação de proteger e melhorar o meio ambiente para as gerações presentes e futuras. Dessa forma, AFONSO DA SILVA ${ }^{17}$, afirma que no campo de proteção ao meio ambiente laboral a Declaração de Estocolmo foi a pionera para que as Constituições supervenientes reconhecessem o meio ambiente ecologicamente equilibrado como um direito fundamental entre os direitos sociais do homem, trazendo a importante característica de que são direitos a serem realizados e não perturbados. É importante dizer, que o direito à vida, como matriz de todos os demais direitos fundamentais do homem deve orientar todas as formas de atuação no

\footnotetext{
${ }^{16}$ Artigo XXII. Toda pessoa tem direito ao trabalho, à livre escolha de emprego, a condições justas e favoráveis de trabalho e à proteção contra o desemprego. 2. Toda pessoa, sem qualquer distinção, tem direito a igual remuneração por igual trabalho. 3. Toda pessoa que trabalhe tem direito a uma remuneração justa e satisfatória, que lhe assegure, assim como à sua família, uma existência compatível com a dignidade humana, e a que se acrescentarão, se necessário, outros meios de proteção social. 4. Toda pessoa tem direito a organizar sindicatos e neles ingressar para proteção de seus interesses. Artigo XXIV: Toda pessoa tem direito a repouso e lazer, inclusive a limitação razoável das horas de trabalho e férias periódicas remuneradas. Artigo XXV: Toda pessoa tem direito a um padrão de vida capaz de assegurar a si e a sua família saúde e bem estar, inclusive alimentação, vestuário, habitação, cuidados médicos e os serviços sociais indispensáveis, e direito à segurança em caso de desemprego, doença, invalidez, viuvez, velhice ou outros casos de perda dos meios de subsistência fora de seu controle. 2. A maternidade e a infância têm direito a cuidados e assistência especiais. Todas as crianças nascidas dentro ou fora do matrimônio, gozarão da mesma proteção social.

${ }^{17}$ SILVA, José Afonso. Direito Ambiental Constitucional. São Paulo: Malheiros, 1998, (p.6-70).
} 
campo da proteção ao meio ambiente. Essa, é fundamental porque, é através dela que se protege um valor maior, a vida humana.

Do que foi exposto, podemos extrair algumas considerações. A primeira delas é a de que o direito a um meio ambiente seguro e saudável é um direito fundamental do trabalhador, pois, garante-lhe a vida e a saúde que são necessárias a sua própria sobrevivência e da sua família. A segunda, é que a proteção aos direitos fundamentais do trabalhador deve acompanhar a evolução tecnológica e as necessidades atuais do mercado laboral, na medida em que o trabalhador fica exposto, cada vez mais, a novos riscos. A terceira, é que se os textos legais se tornaram obsoletos deixando de dispensar a devida proteção ao homem que sobrevive do seu trabalho, cabendo aos intérpretes atribuírem-lhes a visão transformadora para assegurar a proteção a vida e a saúde nos ambientes laborais.

As inovações tecnológicas implementadas nas empresas, em decorrência dos avanços ocorridos pela globalização, acabaram trazendo inúmeras modificações na forma de execução do trabalho humano, atingindo o que o trabalhador tem de mais precioso: a sua dignidade. Neste contexto, o trabalho continuou sendo uma importante fonte de inovação e produtividade, porém, as mudanças na sua forma de execução tem feito com que estudiosos, políticos e sindicalistas passassem a se preocupar com o meio ambiente laboral. Desta forma, o mesmo labor humano que alcançou, no decorrer da história, uma dimensão de dignidade e de direito fundamental, continua sendo visto como mera mercadoria apta a gerar lucro, onde o trabalhador é percebido como peça descartável a ponto de convivermos com questões absurdas e inaceitáveis como o trabalho infantil, o trabalho escravo e as mais variadas formas de assédio ou violência no trabalho. Mais adiante, dedicaremos vários momentos a tarefa de discutir o assédio, a 
violência no trabalho, a segurança e a saúde do trabalhador, considerando o que expressam os principais Documentos internacionais e a legislação sobre o tema, e, enfocando também, as ações preventivas utilizadas para inibir esse tipo de conduta no ambiente laboral.

\subsubsection{Na Organização Internacional do Trabalho (OIT)}

A Organização Internacional do Trabalho (OIT) é uma agência multilateral ligada a ONU estruturada de forma tripartite, com participação voluntária de representantes de governos, empresários e trabalhadores dos países que dela são membros. Como órgão normativo a agência elabora e aprova Normas Internacionais Trabalhistas: as convenções e as recomendações ${ }^{18}$.

No entanto, o Documento mais importante no que se refere ao amparo trazido para os trabalhadores no plano internacional, e no que respeita ao âmbito da OIT é a Declaração relativa aos Princípios e Direitos Fundamentais no Trabalho de $1998^{19}$. Ainda, é importante destacar as Convenções n. 29 de 1930 e a 105 de 1957 que estão em sintonia com o artigo $4^{\circ}$ da Declaração Universal de 1948, onde se prevê a proibição da escravidão e da servidão no ambiente de trabalho. Em relação a não-discriminação, prevista no art. $7^{\circ}$ da Declaração Universal dos Direitos Humanos, a Convenção n. 100 de 1951 prevê a igualdade de remuneração para o trabalho de igual valor e a Convenção n. 111 de 1958, a não-discriminação em matéria de emprego e ocupação.

\footnotetext{
${ }^{18}$ A Convenção é divulgada aos países integrantes para ser ratificada, transformada em lei nacional de acordo com as regras de cada constituição nacional. Quando não é ratificada, o país não assume a responsabilidade frente à OIT, mas deve justificar as razões para a não ratificação e esclarecer como sua legislação trata o assunto, dizendo até que ponto aplica ou pretende aplicar os dispositivos da convenção. A recomendação é uma norma com dispositivos que devem ser incorporados nas legislações nacionais. São propostas a serem incorporadas pelos países que se, acatadas, podem transformar-se em leis ou outros mecanismos de regulação. Fonte: Observatório Social. Responsabilidade Social Empresarial perspectivas para a atuação sindical. Florianópolis (SC), Fevereiro 2004, (p.34).

${ }^{19}$ Declaração adotada pela Conferência Internacional do Trabalho em sua 86 $6^{\mathrm{a}}$ sessão, em Genebra.
} 
Ainda, cabe destacar as Convenções de n. 87 e 98, de 1948 e 1949, respectivamente, onde os sindicatos têm garantida a sua existência, em perfeita sintonia com o artigo XXIII. 4 da Declaração Universal, onde diz que toda a pessoa pode fundar sindicatos ou sindicalizar-se. Dentre outras Convenções onde os direitos fundamentais do trabalhador são considerados, destacamos a proibição das piores formas de trabalho infantil, previstos na Convenção n ${ }^{\circ} 182$ de 1999 e a de n. 138 de 1973 que estipula a idade mínima de admissão ao emprego.

Da lista de Convenções acima, o Brasil só não ratificou a convenção n. 87, já os países da União Européia ratificaram todas, mesmo quando não é ratificada uma convenção os países membros são obrigados a respeitarem os direitos fundamentais tratados nas convenções.

Em relação aos riscos à saúde e à segurança do trabalhador, destacamos a Convenção n. 155 que, em seu artigo 16 prevê que será exigido dos empregadores, na medida do possível e razoável, que garantam que os locais de trabalho que estejam sob seu controle sejam seguros e não envolvam risco algum para as pessoas que nele trabalham. Já o artigo 19 da mesma Convenção, prevê que os representantes dos trabalhadores recebam informações adequadas sobre as medidas adotadas pelo empregador no sentido de garantir a segurança e a saúde de seus empregados. Ainda dispõe que, os trabalhadores recebam treinamento sobre as normas de segurança e higiene no trabalho.

Enquanto isso, a convenção n. 161 relativa aos serviços de saúde no trabalho prevê em seu artigo $5^{\circ}$, que os serviços de saúde no trabalho devam assegurar as funções, que sejam adequadas e ajustadas aos riscos da empresa com relação à saúde no trabalho. Dentre elas está a de identificar e avaliar os riscos para a saúde presentes no 
local de trabalho, incluindo em nosso entender, também os riscos relativos à saúde psíquica do trabalhador; permitir que eles participem na elaboração dos programas para a melhoria das práticas no trabalho, e dos testes de avaliação dos novos equipamentos, como medida necessária para evitar acidentes de trabalho e das doenças profissionais. Essas medidas previstas na Convenção permitem que o empresário, os trabalhadores e os representantes dos trabalhadores possam acompanhar o processo de melhoria e cuidado das condições do meio ambiente laboral. Ainda, o artigo 13 reza que os trabalhadores sejam informados sobre os riscos para a saúde inerentes ao trabalho, incorporando assim, o direito do acesso à informação.

Como se pode verificar, essas normas são de ordem pública e, portanto, indisponíveis porque protegem a saúde, a segurança, o bem estar do trabalhador e sua própria vida, não podendo ser negociadas ou ajustadas no contrato de trabalho.

Ainda, é importante destacar a Declaração da Filadélfia de 1944, onde a comunidade internacional reconheceu que o trabalho não é uma mercadoria. Nesta época, já se considerava o trabalho como parte da vida diária e fator determinante para alcançar a dignidade humana. Afirmava-se, que o desenvolvimento econôminco precisava incluir a criação de empregos em condições de trabalho adequadas para que as pessoas pudessem trabalhar com liberdade, segurança e dignidade. Nesse aspecto, a OIT sempre defendeu que as normas internacionais de trabalho são estabelecidas para garantir o desenvolvimento econômico, mas, devem centrar-e na proteção e melhoria da vida e na dignidade humana.

A Organização adotou em 2008 a Declaração sobre Justiça Social para uma Globalização Justa, baseada na Declaração da Filadélfia de 1944 e na Declaração sobre os Princípios e Direitos Fundamentais no Trabalho de 1998. Ela expressa uma 
visão mais contemporânea e considera os avanços tecnológicos e a era da globalização em que estamos vivendo. $\mathrm{O}$ documento foi construído após consultas à Comissão Mundial sobre a Dimensão Social da Globalização. Os Estados membros, ao aprovarem o texto, enfatizaram o alcance de um dos seus objetivos que é conquistar o progresso e a justiça social no contexto da globalização. A Declaração adota o modelo de trabalho digno, institucionalizando sua definição com os seguintes objetivos estratégicos: emprego, proteção social, diálogo social e direitos no trabalho. A Comissão reconhece que um dos princípios fundamentais no trabalho é a condição de trabalho saudável e segura, respeitando, promovendo e aplicando os princípios já firmados anteriormente. Cabe então, a cada Estado membro desenvolver políticas internas de proteção nesse sentido.

Em 2002, OIT editou um informe sobre algumas formas de configuração do assédio moral no trabalho, elencando várias condutas comuns. O rol estabelecia que, o assédio moral consistia em uma medida destinada a excluir uma pessoa de uma atividade profissional; os comportamentos que caracterizariam o assédio no ambiente e laboral seriam, por exemplo, ataques persistentes e negativos ao rendimento pessoal do trabalhador sem nenhuma razão e manipulação da reputação pessoal ou profissional de uma pessoa através de rumores e ridicularização; abuso de poder através do menosprezo persistente do trabalho da pessoa ou da fixação de objetivos com prazos inatingíveis ou pouco razoáveis ou a atribuição de tarefas impossíveis e o Controle desmedido ou inapropriado do rendimento de uma pessoa que trabalha.

Nesse sentido é importante dizer que, as normas editadas pela OIT, tal como o informe acima referido, que proíbem o assédio moral no ambiente de trabalho e a Convenção 111 que proíbe qualquer tipo de discriminação, devem ser observadas 
como verdadeiros "sobreprincípios" dentro do ordenamento jurídico interno, de cada Estado, cabendo a eles tomar as medidas necessárias para o efetivo respeito a esses direitos, realizando medidas preventivas e repressoras.

Lembrando que cada Estado membro é obrigado a apresentar a cada 02 anos um relatório sobre as medidas adotadas para aplicar na legislação e na prática as convenções ratificadas, encaminhando essas informações para as organizações de empregadores e trabalhadores. O Comitê de Especialistas na Aplicação de Convenções e Recomendações é encarregado de examinar tais relatórios. As organizações de empregadores e de trabalhadores podem denunciar o Estado-Membro pelo descumprimento de uma Convenção. E também os Estados membros podem apresentar denúncias contra outro membro que não esteja cumprindo corretamente uma Convenção. E por último os governos podem submeter um desacordo quanto ao cumprimento das normas internacionais ao Tribunal Internacional de Justiça ${ }^{20}$.

\subsubsection{No Mercado Comum do Sul (MERCOSUL)}

No âmbito do Mercosul $^{21}$ tem se buscado o reconhecimento da importância da dimensão sociolaboral, incluindo os direitos trabalhistas. Os aspectos trabalhistas e sociais foram ganhando espaço pela pressão dos agentes sócioeconômicos e por causa da consolidação do processo de integração, removendo a idéia de que o Mercosul se tornasse um mero bloco de integração comercial. Foi então que, a

\footnotetext{
${ }^{20}$ Site da OIT no Brasil: <http://www.oitbrasil.org.br/>. Acesso em 25.10.2009.

${ }^{21}$ O Mercado Comum do Sul (Mercosul) é um amplo projeto de integração concebido pela Argentina, Brasil, Paraguai e Uruguai. Envolve as dimensões econômicas, políticas e sociais, o que se pode inferir da diversidade de órgãos que o compõem, os quais cuidam de temas tão variados quanto agricultura familiar ou cinema, por exemplo. No aspecto econômico, o Mercosul assume, hoje, o caráter de União Aduaneira, mas, seu fim último, visa constituir-se em verdadeiro mercado comum, seguindo os objetivos estabelecidos no Tratado de Assunção, por meio do qual o bloco foi constituído em 1991.
} 
Declaração Sociolaboral $^{22}$ adotada em 1998 entrou em vigor, contemplando a análise das legislações trabalhistas dos países integrantes do bloco e tendo como base as diretrizes sobre os direitos fundamentais no trabalho contemplados pela OIT. A Declaração reconhece uma série de direitos comuns aos trabalhadores do bloco, independentemente do comércio regional. $\mathrm{O}$ artigo 25 dispõe que os direitos sociais mencionados, tanto no instrumento como no mecanismo de aplicação, não podem ser invocados em questões comerciais, econômicas e financeiras. Deste modo, o bloco Mercosul, quanto aos Direitos Humanos dos trabalhadores, parece privilegiar a concepção de Direitos Humanos como princípios ou diretrizes políticas ${ }^{23}$.

No Documento, o item relativo aos direitos individuais e da nãodiscriminação no emprego, encontra-se incorporado nas Constituições dos quatro países do Mercosul, garantindo, basicamente a igualdade de salários e remuneração para igual tarefa. Os países integrantes do bloco reiteraram sua intenção com a ratificação das Convenções da OIT de números 100 - que trata da igualdade de remuneração e 111 que trata da igualdade no emprego e na ocupação.

Assim, a não-discriminação é garantido através da igualdade efetiva de direitos, do tratamento e da oportunidade no emprego e na ocupação, sem distinção ou exclusão por motivos de raça, origem nacional, cor, sexo ou orientação sexual, idade, credo, opinião pública ou sindical, ideologia, posição econômica ou qualquer outra condição social ou familiar. $\mathrm{O}$ artigo $2^{\circ}$ da Declaração prevê que, as pessoas portadoras de necessidades especiais serão tratadas de forma digna e não discriminatória, favorecendo a sua inserção social no mercado de trabalho. Os Estados partes

\footnotetext{
${ }^{22}$ Declaração Sociolaboral do Mercosul, pode ser encontrada na página do Ministério do Trabalho e emprego do Brasil. Disponível em:<http://www.mte.gov.br/eventos/mercosul/default.asp>. Acesso em 20.10.2009.

${ }^{23}$ Op. Cit. Nota 13, (p.69).
} 
comprometem-se a adotar medidas efetivas para a educação, formação, readaptação e orientação profissional, à adequação dos ambientes de trabalho e ao acesso aos bens e serviços coletivos, a fim de assegurar que estas pessoas tenham a possibilidade de desempenhar uma atividade produtiva. Além disso, foi criada a Comissão SócioLaboral, uma comissão tripartida formada por representantes governamentais, sindicais e empresariais, com a missão de auxiliar, acompanhar e fomentar os objetivos da Declaração.

Cabe lembrar, que a Declaração é de caráter meramente indicativo, não tendo a conotação de um direito comunitário trabalhista. Ela serve para introduzir de forma definitiva os temas laborais dentro do Mercosul. No entanto, ainda falta estabelecer um sistema de regulação das relações de trabalho no Mercosul, já que a mobilização dos trabalhadores nesta região é intensa.

\subsubsection{Na União Européia (UE)}

A partir da Declaração Universal dos Direitos Humanos de 1948 no âmbito Europeu, o desenvolvimento de instrumentos para a proteção e efetivação dos direitos fundamentais foi crescendo. Exemplo disso, é a Convenção de Salvaguarda dos Direitos do Homem e das Liberdades Fundamentais aprovada em Roma em 1950, que instituiu dois órgãos importantes para assegurar os direitos contidos na Convenção: a Comissão Européia dos Direitos do Homem e o Tribunal Europeu dos Direitos do Homem. A Comissão suspendeu suas funções em 1998, quando o Tribunal Europeu passou a exercer as atividades que ela desempenhava. Até novembro do mesmo ano, este órgão examinava a admissibilidade de todos os procedimentos de um indivíduo ou Estado interposto contra um Estado membro. Cabe destacar que, o Tribunal tem por 
objetivo garantir o respeito por parte dos Estados signatários das obrigações estabelecidas pelo Convênio funcionando de forma permanente ${ }^{24}$.

A Carta Social Européia, aprovada em Turin em 1961, veio regulamentar uma série de direitos e princípios laborais. Dentre eles, destaca-se o direito as condições equitativas de trabalho, seguridade e higienie, a remuneração equitativa, ao direito a organização sindical, ao direito à negociação coletiva, ao direito à proteção às crianças e aos adolescentes trabalhadores e ao direito à seguridade social.

Nesse contexto vale frisar a Diretiva ${ }^{25} 2002 / 73$ do Parlamento Europeu e do Conselho de 23 de setembro de 2002 que modifica a Diretiva 76/207/CEE de 1976, relativa ao princípio da igualdade de tratamento entre homens e mulheres no que se refere ao acesso ao emprego, às condições de trabalho e à formação e promoção profissionais. O documento reza em seu artigo $3^{\circ}$ que a aplicação do princípio de igualdade de tratamento implica a ausência de qualquer discriminação em razão de sexo nas condições de acesso, seleção ao emprego ou a postos de trabalho, independentemente do setor ou ramo de atividade e a todos os níveis de hierarquia profissional. Trazendo em seu artigo $2^{\circ}$ no item 2 as definições sobre a discriminação direta e indireta, o assédio e o assédio sexual. Segundo a diretiva o assédio e o assédio sexual são considerados discriminação em razão de sexo, e portanto, proibidos.

\footnotetext{
${ }^{24}$ Informações retiradas do site: $\langle$ http://www.coe.int/T/ES/Com/About_Coe/Nepasconfondre.asp $>$. Acesso em 17.10.2009.

${ }^{25}$ Para o desempenho das suas atribuições o Parlamento Europeu em conjunto com o Conselho, o Conselho e a Comissão adotam regulamentos e diretivas, formulando decisões, recomendações ou pareceres. A diretiva vincula o Estado-Membro destinatário quanto ao resultado a alcançar, deixando às instâncias nacionais a competência quanto à forma e aos meios. Configuram "expressões do poder hierárquico contendo instruções das instituições comunitárias endereçadas aos estados-membros", podendo serem adotadas através de uma variedade de procedimentos legislativos, em função do seu objeto. As Diretivas podem ser encontradas no site: <http://eur-lex.europa.eu/RECH_legislation>. Acesso em 26.11.2009.
} 
Nesse sentido, importante também é a Recomendação 131 de 1992 da Comissão Européia ${ }^{26}$, que visa proteger a dignidade da mulher e estabelece estratégias a serem adotadas por empregadores e sindicatos para a prevenção dos abusos sexuais, com proteção à vítima do abuso sexual. A referida Recomendação, prevê a criação de um programa de política gerencial entre os representantes dos trabalhadores e empregadores. A recomendação supracitada estabelece procedimentos que estimulam a denúncia do abuso sexual, priorizando o sigilo da denúncia.

Outra Diretiva igualmente importante no que refere a dignidade do trabalhador no âmbito da UE é a 2000/78CE de 27 de novembro, que tem por objetivo estabelecer um quadro geral para lutar contra a discriminação em razão de religião, convicção, deficiência, idade ou orientação sexual, no que se refere ao emprego e a atividade profissional, entendendo o princípio de igualdade de tratamento como a ausência de qualquer discriminação direta ou indireta, sempre que uma pessoa seja objeto de um tratamento menos favorável por algum desses motivos. No que diz respeito ao assédio, o documento dispõe que essa conduta é considerada discriminação sempre que ocorrer um comportamento indesejado, com o objetivo ou o efeito de violar a dignidade de uma pessoa ou criar um ambiente de trabalho intimidatório, hostil, degradante, humilhante ou desestabilizador ${ }^{27}$. O mesmo princípio reza a Diretiva 2000/43/CE de 29 de junho relativa à aplicação do princípio de igualdade de trato das pessoas independentemente de sua origem racial ou étnica, afirmando também que o assédio constitui discriminação, ferindo assim dignidade humana.

\footnotetext{
${ }^{26}$ 92/131/CEE: Recomendação da Comissão, de 27 de Novembro de 1991, relativa à proteção da dignidade da mulher e do homem no trabalho Jornal Oficial nº L 049 de 24.02.1992 p. 00010008. Disponível em: <http://www.cite.gov.pt/pt/acite/legislacaocomu04.html〉. Acesso em 23.03.2009.

${ }^{27}$ Diretiva 2000/78/CE. Relativa ao establecimiento de um marco general para la igualdad de trato en el empleo y la ocupación. Publicado no Diário Oficial de las Comunidades Europeas L303 de 21.12.2000.
} 
Ao nosso entender, a conduta de assédio é considerado discriminação no ambiente de trabalho porque expõe o trabalhador a situações de desigualdade de forma proposital e sem motivo legítimo. Já o assédio sexual elege uma vítima para constranger tratando-a de forma diferente dos demais.

A Carta de Direitos fundamentais da UE de dezembro de 2000 estabelece em seu artigo $1^{\circ}$ que a dignidade humana é inviolável e deve ser respeitada e protegida, ademais, em seu artigo 20 aborda o princípio geral de igualdade perante a lei e o 21 dispõe sobre a não discriminação por motivos de raça, cor, origem étnica, religião ou convicções, incapacidade, idade ou orientação sexual, motivos esses mencionados no artigo 13 do Tratado Constitutivo da Comunidade Européia. Ainda na Carta o artigo 23 traz a igualdade entre homens e mulheres em matéria de emprego.

As informações sobre a igualdade entre homens e mulheres no que respeita ao trabalho e a colocação no mercado de trabalho encontram-se no "Relatório da Comissão ao Conselho, ao Parlamento Europeu, ao Comitê Econômico e Social Europeu e ao Comitê das Regiões de 23 de Janeiro de 2008", afirma que do ponto de vista quantitativo, a situação das mulheres registra processos significativos, como a participação no mercado de trabalho e que seu nível de habilitações é superior ao dos homens. Porém o aspecto quantitativo ainda sofre desafios em matéria de disparidade de salário. $\mathrm{O}$ documento indica os principais progressos sobre o tema ${ }^{28}$.

Percebemos que, em sentido amplo, a política da UE sobre a não discriminação, a igualdade no tratamento de trabalhadores e trabalhadoras e a defesa da sua dignidade estão claramente expostos nesses documentos, constituindo instrumentos a favor do estudo aqui exposto. Contudo as referências sobre a legislação Européia a

\footnotetext{
${ }^{28}$ Disponível em: <http://europa.eu/legislation_summaries/index_es.htm>. Acesso em 26.11.2009.
} 
respeito do tema não se esgotam aqui, veremos mais adiante outras não menos importantes.

\section{2 . Os Direitos Fundamentais do Trabalhador na Ordem Jurídica}

\section{Brasileira}

O breve histórico das Declarações de direitos já referido, demonstra que o entendimento a respeito do trabalho e da dignidade da pessoa humana que levou o legislador a compreender que, um trabalho decente e justo vem imbuído do conceito e da noção de dignidade. Dessa forma, a Carta Magna da República Federativa do Brasil, valoriza esse princípio fundamental em seu artigo $1^{\circ}$, inciso III, prevendo a dignidade da pessoa humana como um dos fundamentos do Estado Democrático de Direito. A dignidade da pessoa humana é um princípio construído pela história e incorporado nas Constituições modernas, consagrando um valor que visa proteger o ser humano contra tudo o que lhe possa causar dano. A Carta considerada "Constituição cidadã", constitui um importante instrumento de proteção jurídica contra a violência nas relações laborais, nela estão estruturadas a tutela jurídica à personalidade e dignidade do trabalhador.

Nesse diapasão a Constituição brasileira, concede natureza de direito social ao cidadão brasileiro, nos termos do $\operatorname{artigo} 6^{\circ}$ revelando que o Estado não fugiu à regra dos demais Estados modernos e incluiu o seguinte texto: "São direitos sociais a educação, a saúde, o trabalho, a moradia, o lazer, a segurança, a previdência social, a proteção à maternidade e à infância, a assistência aos desamparados, na forma desta Constituição." Fala-se, então, que o direito ao trabalho enquanto um direito social previsto na Constituição entre os seus princípios fundamentais, traz consigo a idéia de trabalho digno, o que está exposto claramente na disposição contida no inciso III do 
artigo $1^{\circ}$ elege a dignidade da pessoa humana como um dos fundamentos da República Federativa do Brasil, e em especial, como uma característica do Estado Democrático de Direito.

O princípio da não discriminação, está previsto na $\mathrm{CF}$ em seus artigos $3^{\circ}$, IV, $5^{\circ}$ e $7^{\circ}$, caput e incisos XX, XXX, XXXI, XXXII e XXXIV. Na esfera infraconstitucional têm-se a proteção através das leis ordinárias 9.029/95 que proíbe a exigência de atestados de gravidez e esterilização, e outras práticas discriminatórias, para efeitos admissionais ou de permanência da relação jurídica de trabalho, por motivo de sexo, origem, raça e cor, estado civil, situação familiar ou idade. É evidente que esse tipo de conduta por parte do empregador atenta contra o direito fundamental do trabalhador de ser tratado com devida consideração e de não ser discriminado por qualquer motivo. Se esses atos são praticados de forma sistemática, além de caracterizar abuso do poder pela empresa e discriminação, também podem tipificar uma conduta assediante, constituindo uma violação à sua dignidade. Já a lei 9.799/99 que inseriu na Consolidação das Leis do Trabalho (CLT), lei $n^{\circ}$ 5.452/43 o artigo 373-A, ampliando assim as medidas antidiscriminatórias para que a mulher possa ter acesso ao mercado de trabalho. No que refere ao assédio sexual, a lei brasileira $\mathrm{n}^{\circ} 10.224$ de 15 de maio de 1991, que criou o artigo 216-A do Código Penal, define assédio sexual como crime. A norma expressa que "O assédio sexual é uma coerção de caráter sexual, praticada por uma pessoa em posição hierárquica superior em relação a um $(a)^{29}$ subordinado (a)".

Nesse sentido os aplicadores e doutrinadores do direito do trabalho devem apoiar-se nas normas constitucionais e infraconstitucionais que de uma maneira

\footnotetext{
${ }^{29} \mathrm{O}$ uso desse artigo (a) no texto utiliza-se, porque, o crime pode ser utilizado tanto por um homem como por uma mulher.
} 
ou de outra protegem a personalidade e a dignidade da pessoa, adequando onde couber nas relações de trabalho.

Por serem os princípios os pilares estruturais do direito, a violação deles é considerada tão grave quanto a violação das leis. Se uma lei for aprovada e seu texto conter a violação de um princípio, é possível dizer que, este fato gera a inconstitucionalidade da norma. Todavia, não são raros os casos de violação dos princípios fundamentais especialmente nas questões ligadas ao assédio moral, ao assedio sexual e ao assédio por razão de sexo. Cabe lembrar que, o trabalho digno é, sem dúvida, uma das principais ferramentas para a consolidação do respeito à dignidade da pessoa humana. Sendo assim, com o meio de proteção aos direitos e garantias fundamentais, onde estão inseridos os direitos de personalidade, a $\mathrm{CF}$ artigo $5^{\circ}$, inciso $\mathrm{X}$ dispõe como proteção jurídica o direito de exige do violador a indenização por dano moral e material.

Além da promoção e valorização do trabalho, o legislador previu a proteção à saúde do trabalhador nos artigos 196 e $200^{30}$. Desse modo, os valores

\footnotetext{
${ }^{30}$ Art. 196. A saúde é direito de todos e dever do Estado, garantido mediante políticas sociais e econômicas que visem à redução do risco de doença e de outros agravos e ao acesso universal e igualitário às ações e serviços para sua promoção, proteção e recuperação. Art. 197. São de relevância pública as ações e serviços de saúde, cabendo ao Poder Público dispor, nos termos da lei, sobre sua regulamentação, fiscalização e controle, devendo sua execução ser feita diretamente ou através de terceiros e, também, por pessoa física ou jurídica de direito privado.

Art. 198. As ações e serviços públicos de saúde integram uma rede regionalizada e hierarquizada e constituem um sistema único, organizado de acordo com as seguintes diretrizes: I - descentralização, com direção única em cada esfera de governo; II - atendimento integral, com prioridade para as atividades preventivas, sem prejuízo dos serviços assistenciais; III - participação da comunidade. $\S 1^{\circ}$. O sistema único de saúde será financiado, nos termos do art. 195, com recursos do orçamento da seguridade social, da União, dos Estados, do Distrito Federal e dos Municípios, além de outras fontes. (Parágrafo único renumerado para $\S 1^{\circ}$ pela Emenda Constitucional $n^{\circ} 29$, de 2000)§ $2^{\circ}$ A União, os Estados, o Distrito Federal e os Municípios aplicarão, anualmente, em ações e serviços públicos de saúde recursos mínimos derivados da aplicação de percentuais calculados sobre: (Incluído pela Emenda Constitucional $n^{\circ} 29$, de 2000) I - no caso da União, na forma definida nos termos da lei complementar prevista no $\S 3^{\circ}$; (Incluído pela Emenda Constitucional $n^{\circ} 29$, de 2000) II - no caso dos Estados e do Distrito Federal, o produto da arrecadação dos impostos a que se refere o art. 155 e dos recursos de que tratam os arts. 157 e 159 , inciso I, alínea a, e inciso II, deduzidas as parcelas que forem transferidas aos respectivos Municípios; (Incluído pela Emenda Constitucional no 29, de 2000) III - no caso dos Municípios e do Distrito Federal, o produto da arrecadação dos impostos a que se refere o art. 156 e dos recursos de que tratam os arts. 158 e 159 ,
} 
humanos, sociais e do trabalho, o sentido e a função social da propriedade e, consequentemente do contrato, inclusive por várias razões do contrato de trabalho, onde ocorre um pacto que tem por objeto o trabalho humano, a proteção e a defesa do meio ambiente receberam da Carta, uma proteção especial como já dissemos. Esta, está prevista nos artigos $1^{\circ}$ III e IV; $6^{\circ}, 7^{\circ}$ XXII; 170 III, 186 II; 193; 200 II e 225, com destaque para a saúde do trabalhador, porque, representa um complemento necessário do direito à vida entendido aqui com o sentido de vida de digna.

inciso I, alínea b e $\S 3^{\circ}$. (Incluído pela Emenda Constitucional no 29, de 2000)§ $3^{\circ}$ Lei complementar, que será reavaliada pelo menos a cada cinco anos, estabelecerá: (Incluído pela Emenda Constitucional $n^{\circ} 29$, de 2000) I - os percentuais de que trata o $§ 2^{\circ}$; (Incluído pela Emenda Constitucional $n^{\circ} 29$, de 2000) II os critérios de rateio dos recursos da União vinculados à saúde destinados aos Estados, ao Distrito Federal e aos Municípios, e dos Estados destinados a seus respectivos Municípios, objetivando a progressiva redução das disparidades regionais; (Incluído pela Emenda Constitucional no 29, de 2000) III - as normas de fiscalização, avaliação e controle das despesas com saúde nas esferas federal, estadual, distrital e municipal; (Incluído pela Emenda Constitucional n ${ }^{\circ} 29$, de 2000) IV - as normas de cálculo do montante a ser aplicado pela União.(Incluído pela Emenda Constitucional no 29, de 2000)§ $4^{\circ}$ Os gestores locais do sistema único de saúde poderão admitir agentes comunitários de saúde e agentes de combate às endemias por meio de processo seletivo público, de acordo com a natureza e complexidade de suas atribuições e requisitos específicos para sua atuação. (Incluído pela Emenda Constitucional $\mathrm{n}^{\circ}$ 51, de 2006)§ $5^{\circ}$ Lei federal disporá sobre o regime jurídico e a regulamentação das atividades de agente comunitário de saúde e agente de combate às endemias. (Incluído pela Emenda Constitucional $n^{\circ}$ 51, de 2006) (Vide Medida provisória $n^{\circ} 297$. de 2006) Regulamento $6^{\circ}$ Além das hipóteses previstas no $\S 1^{\circ}$ do art. 41 e no $\S 4^{\circ}$ do art. 169 da Constituição Federal, o servidor que exerça funções equivalentes às de agente comunitário de saúde ou de agente de combate às endemias poderá perder o cargo em caso de descumprimento dos requisitos específicos, fixados em lei, para o seu exercício. (Incluído pela Emenda Constitucional $\mathrm{n}^{\circ}$ 51, de 2006).

Art. 199. A assistência à saúde é livre à iniciativa privada. $\S 1^{\circ}$ - As instituições privadas poderão participar de forma complementar do sistema único de saúde, segundo diretrizes deste, mediante contrato de direito público ou convênio, tendo preferência as entidades filantrópicas e as sem fins lucrativos. $2^{\circ}$ É vedada a destinação de recursos públicos para auxílios ou subvenções às instituições privadas com fins lucrativos. $\S 3^{\circ}$ - É vedada a participação direta ou indireta de empresas ou capitais estrangeiros na assistência à saúde no País, salvo nos casos previstos em lei.§ $4^{\circ}$ - A lei disporá sobre as condições e os requisitos que facilitem a remoção de órgãos, tecidos e substâncias humanas para fins de transplante, pesquisa e tratamento, bem como a coleta, processamento e transfusão de sangue e seus derivados, sendo vedado todo tipo de comercialização.

Art. 200. Ao sistema único de saúde compete, além de outras atribuições, nos termos da lei: I - controlar e fiscalizar procedimentos, produtos e substâncias de interesse para a saúde e participar da produção de medicamentos, equipamentos, imunobiológicos, hemoderivados e outros insumos; II - executar as ações de vigilância sanitária e epidemiológica, bem como as de saúde do trabalhador; III - ordenar a formação de recursos humanos na área de saúde; IV - participar da formulação da política e da execução das ações de saneamento básico; V- incrementar em sua área de atuação o desenvolvimento científico e tecnológico; VI - fiscalizar e inspecionar alimentos, compreendido o controle de seu teor nutricional, bem como bebidas e águas para consumo humano; VII - participar do controle e fiscalização da produção, transporte, guarda e utilização de substâncias e produtos psicoativos, tóxicos e radioativos; VIII colaborar na proteção do meio ambiente, nele compreendido o do trabalho.

Informações retiradas da obra: Constituição da República Federativa do Brasil de 1988. BRASIL. Constituição Federal Brasileira. São Paulo: Saraiva, 2007. 
GOMES CANOTILHO ${ }^{31}$ revela que, as consequências de uma proteção integrada ao ambiente - e a todos os seus integrantes são relevantes sob vários aspectos, pois o bem protegido - "bem ambiente" - tem subjacente uma concepção ampla de ambiente que engloba não apenas o conceito de ambiente naturalista, mas, o ambiente como conjunto de sistemas físicos, químicos, biológicos e as suas relações e os fatores econômicos, sociais e culturais com efeito direto e indireto, mediato ou imediato, sob os seres vivos e a qualidade de vida do homem. Dissemos ainda que, se deve entender como meio ambiente do trabalho, o local em que se desenrola grande parte da vida do trabalhador, sendo, por isso que, a qualidade do ambiente está estritamente relacionada com a qualidade de vida.

Ainda nesse sentido, o artigo 225 da Carta, dispõe que todos têm direito ao meio ambiente ecologicamente equilibrado, impondo-se ao poder público o dever de preservá-lo para gerações presentes e futuras. Para assegurar a efetividade desse direito, o Estado deve promover a educação ambiental em todos os níveis de ensino realizando a conscientização pública para a preservação do meio ambiente.

No que respeita à proteção infraconstitucional da proteção aos direitos de personalidade, oportuno trazer o artigo 12 do Código Civil ${ }^{32}$, que dispõe "Pode-se exigir que cesse a ameaça, ou lesão, a direito a personalidade, e reclamar perdas e danos (material e moral), sem prejuízo de outras sanções previstas em lei”. De acordo com ALKIMIN ${ }^{33}$, o Código Civil adotou a teoria preventiva, pela qual garante a proteção jurisdicional ao bem jurídico pessoal da vítima antes mesmo de a lesão se

\footnotetext{
${ }^{31}$ CANOTILHO José Joaquim Gomes. Estado Constitucional, Ecológico e Democracia Sustentada. Apud: GRAU. Eros Roberto (Coord.). Estudos de Direito Constitucional em homenagem a José Afonso da Silva. São Paulo: Malheiros, 2003, (p.102-110).

${ }^{32}$ Código Civil (Lei 10.406) de 10 de Janeiro de 2002. Disponível em: http://www.planalto.gov.br/CCIVIL/leis/2002/L10406.htm>. Acesso em 28.11.2009.

${ }_{33}^{33}$ ALKIMIN. Maria Aparecida. Violência na Relação de Trabalho e a Proteção à Personalidade do Trabalhador. Curitiba: Juruá, 2008, (p.183).
} 
concretizar, sendo que a reparação pecuniária é medida paliativa que não repara o prejuízo moral sofrido pela vítima, assim, a proteção preventiva prevista pelo legislador aparece no artigo 21: "a vida privada natural é inviolável, e o juiz, a requerimento do interessado, adotará as providências necessárias para impedir ou fazer cessar ato contrário a essa norma."

Dessa forma, se o trabalhador sofrer violência contra seus direitos de personalidade, ele poderá invocar o artigo 483 da $\mathrm{CLT}^{34}$, para que o contrato de trabalho seja rescindido, e que ele receba a indenização trabalhista, podendo também fazer uso do Código Civil para embasar o pedido de reparação por dano moral, porque no Brasil não temos uma proteção específica no que refere aos direitos de personalidade do trabalhador. Assim, esse artigo faculta ao empregado provar em juízo os motivos alegados na ação trabalhista em que acredite a decretação da "rescisão" contratual por falta grave cometida pelo empregador com o pagamento da indenização devida.

Ainda na CLT, há um capítulo específico referente à segurança e medicina do trabalho, nos artigos 189 a $192^{35}$. O texto dispõe sobre o conceito de

\footnotetext{
${ }^{34}$ CLT- art. 483 - O empregado poderá considerar rescindido o contrato e pleitear a devida indenização quando: a) forem exigidos serviços superiores às suas forças, defesos por lei, contrários aos bons costumes, ou alheios ao contrato; b) for tratado pelo empregador ou por seus superiores hierárquicos com rigor excessivo; c) correr perigo manifesto de mal considerável (...); e) praticar o empregador ou seus prepostos, contra ele ou pessoas de sua família, ato lesivo da honra e boa fama; f) o empregador ou seus prepostos ofenderem-no fisicamente, salvo em caso de legítima defesa, própria ou de outrem; g) o empregador reduzir o seu trabalho, sendo este por peça ou tarefa, de forma a afetar sensivelmente a importância dos salários. $\S 1^{\circ}$ - O empregado poderá suspender a prestação dos serviços ou rescindir o contrato, quando tiver de desempenhar obrigações legais, incompatíveis com a continuação do serviço. (...). Disponível em: <http://www.mte.gov.br/legislacao/default.asp>. Acesso em 21.10.2009.

${ }^{35}$ CLT - Das Atividades Insalubres e Perigosas Art. 189 - Serão consideradas atividades ou operações insalubres aquelas que, por sua natureza, condições ou métodos de trabalho, exponham os empregados a agentes nocivos à saúde, acima dos limites de tolerância fixados em razão da natureza e da intensidade do agente e do tempo de exposição aos seus efeitos. Art. 190 - O Ministério do Trabalho aprovará o quadro das atividades e operações insalubres e adotará normas sobre os critérios de caracterização da insalubridade, os limites de tolerância aos agentes agressivos, meios de proteção e o tempo máximo de exposição do empregado a esses agentes. Parágrafo único - As normas referidas neste art. incluirão medidas de proteção do organismo do trabalhador nas operações que produzem aerodispersóides tóxicos, irritantes, alergênicos ou incômodos.
}

Art. 191 - A eliminação ou a neutralização da insalubridade ocorrerá: I - com a adoção de medidas que conservem o ambiente de trabalho dentro dos limites de tolerância; II - com a utilização de equipamentos 
atividades insalubres ou perigosas, o pagamento do respectivo adicional, bem como o fornecimento de Equipamentos de Proteção Individual (EPI's). O legislador celetista delegou ao Ministério do Trabalho e Emprego (MTE) a função de expedir disposições complementares às normas de medicina e segurança no trabalho, considerando as peculiaridades de cada atividade e setor (artigo 200 da CLT). Já o MTE, por sua vez, estabeleceu um conjunto de normas técnicas e complementares conhecidas como normas reguladoras (NR) para orientar o tema. Dentre as principais NR's, destacamos a NR6 que se refere ao fornecimento de EPI's; a NR 9 que dispõe sobre os riscos ambientais e a NR15 que trata das atividades e operações insalubres. Percebemos que há uma intensa preocupação com ruídos, agentes químicos e atividades perigosas, porém, o legislador deixou de normatizar os riscos psicológicos e psicossociais a que o trabalhador está exposto, e que, causam as enfermidades consideradas não visíveis.

A Carta de 1988, indubitavelmente, acolheu a idéia dos direitos humanos dos trabalhadores, constituindo um marco importante na institucionalização desses direitos no Brasil. As garantias fundamentais e a dignidade da pessoa humana, personalizando os princípios constitucionais e consagrando o respeito aos Direitos Humanos fez com que, o Brasil ratificasse vários Acordos internacionais sobre o trabalho e a dignidade do trabalhador, instituindo ainda, que, além dos direitos e garantias mencionados no art. $5^{\circ}$ da $\mathrm{CF}$, não se excluem outros decorrentes do regime e dos princípios por ela adotados, ou dos Tratados internacionais dos quais o país é signatário. No mesmo artigo, a Carta torna expressa que as normas definidoras de

de proteção individual ao trabalhador, que diminuam a intensidade do agente agressivo a limites de tolerância. Parágrafo único - Caberá às Delegacias Regionais do Trabalho, comprovada a insalubridade, notificar as empresas, estipulando prazos para sua eliminação ou neutralização, na forma deste. Art. 192 $\mathrm{O}$ exercício de trabalho em condições insalubres, acima dos limites de tolerância estabelecidos pelo Ministério do Trabalho, assegura a percepção de adicional respectivamente de $40 \%$ (quarenta por cento), $20 \%$ (vinte por cento) e 10\% (dez por cento) do salário mínimo da região, segundo se classifiquem nos graus máximo, médio e mínimo. 
direitos e garantias fundamentais tenham aplicação imediata, constituindo-se em cláusulas pétreas. Isso significa dizer que, essas cláusulas são limitações materiais ao poder de reforma da Constituição do Estado. Representam disposições que proíbem as alterações por meio de emendas, ou, até mesmo, a supressão destes direitos previstos. No artigo $1^{\circ}$, incisos I ao $\mathrm{V}$, o Documento expressa a soberania do Estado brasileiro, o reconhecimento da cidadania, da dignidade da pessoa humana, dos valores socais, da livre iniciativa e do pluralismo político, para justificar a opção pelo Estado Democrático de Direito. Sendo assim, é importante dizer que, a dignidade do trabalho humano é um direito fundamental positivado na Constituição brasileira e um elemento integrador do projeto constitucional fundamentado pelo valor dignidade humana, que representa uma conquista histórica.

De acordo com PIOVESAN ${ }^{36}$ o valor da dignidade humana como um princípio fundamental da nossa Constituição, impõe-se como núcleo informador do ordenamento jurídico brasileiro e como parâmetro de valoração para a compreensão do sistema constitucional instaurado. A dignidade humana e os direitos fundamentais constituídos como princípios constitucionais incorporam, a exigência de justiça e de valores éticos por parte do Estado. No Brasil, os Tratados internacionais de direitos humanos poderão ser incorporados ao direito interno inclusive com força de norma constitucional e com a mesma hierarquia normativa das emendas constitucionais. Para tanto, é necessário que seja respeitado o quórum qualificado previsto no artigo $5^{\circ}$, paragrafo $3^{\circ}$ da $\mathrm{CF}$, onde se prevê que os Tratados e Convenções internacionais sobre direitos humanos devam ser aprovados em cada Casa do Congresso Nacional (Câmara dos Deputados Federais e Senado Federal), em dois turnos e por três quintos dos votos dos respectivos membros, sendo equivalentes às emendas constitucionais.

\footnotetext{
${ }^{36}$ PIOVESAN, Flávia. Temas de Direitos Humanos. São Paulo: Max Limonad, 1988, (pp.44-48).
} 
A mesma Constituição em seu artigo $5^{\circ}$ inciso II, referente aos direitos e garantias fundamentais, diz que os direitos e garantias expressos não excluem outros decorrentes do regime e dos princípios por ela adotados, ou dos Tratados internacionais em que a República Federativa do Brasil seja parte. Neste mesmo sentido, os dispositivos constitucionais presentes também nos artigos 49 I e 84 VIII, sobre as atribuições do Congresso Nacional e do Presidente da República, preceituam, respectivamente, que é da da competência exclusiva do Congresso Nacional resolver definitivamente questões relacionadas aos Tratados, Acordos ou Atos internacionais que acarretem encargos ou compromissos gravosos ao patrimônio nacional. Ao presidente da República cabe privativamente, celebrar Tratados, Convenções e Atos internacionais que estão sujeitos a aprovação pelo Congresso Nacional.

Portanto, é possível perceber que no direito constitucional brasileiro o ato de celebrar tratados com outros Estados e Organizações internacionais é tradição. Quando se tratam de direitos humanos, a sua validade corresponde às normas de caráter constitucional e tem aplicação imediata. Isso, se confirma nos dispositivos dos artigos $4^{\circ}$ II: “A República Federativa do Brasil rege-se nas suas relações internacionais pelos seguintes princípios: (...) II - prevalência dos direitos humanos." Também é possível identificar no artigo $5^{\circ}, \S 3^{\circ}$, “Todos são iguais perante a lei, sem distinção de qualquer natureza, garantindo-se aos brasileiros e aos estrangeiros residentes no País a inviolabilidade do direito à vida, à liberdade, à igualdade, à segurança e à propriedade, nos termos seguintes (...) $\$ 2^{\circ}$ os direitos e garantias expressos nesta Constituição não excluem outros decorrentes do regime e dos princípios por ela adotados, ou dos tratados internacionais em que a República Federativa do Brasil seja parte" e parágrafo $3^{\circ}$ "os tratados e convenções internacionais sobre direitos humanos que forem aprovados, em cada Casa do Congresso Nacional, em dois turnos, por três 
quintos dos votos dos respectivos membros, serão equivalentes às emendas constitucionais. E as garantias fundamentais têm aplicação imediata." Dessa forma, a doutrina brasileira entende que os Tratados internacionais fazem parte de uma cláusula geral de recepção plena, não havendo nenhuma controvérsia quanto a sua incorporação ao ordenamento jurídico interno, especialmente quando se tratam de Direitos Humanos. Nesse mesmo sentido, $\mathrm{CANÇADO}^{37}$ alega que,

Os direitos humanos consagrados em tratados de direitos humanos em que o Brasil seja parte incorporam-se ao direito interno brasileiro, no âmbito do qual passam a ter "aplicação imediata" (art. $5^{\circ}, \S 1^{\circ}$ ), da mesma forma e no mesmo nível que os direitos constitucionalmente assegurados (...). A especificidade e o caráter especial dos tratados de direitos humanos encontram-se, assim, devidamente reconhecidos pela Constituição brasileira vigente.

A partir da Carta de 1988, importantes Tratados internacionais de Direitos Humanos foram ratificados pelo Brasil. Dentre eles, destacamos a Convenção contra a Tortura e outros tratamentos Cruéis Desumanos ou Degradantes (1989); o Pacto Internacional dos Direitos Civis e Políticos (1992); o Pacto Internacional dos Direitos Econômicos Sociais e culturais (1992); a Convenção Americana de Direitos Humanos (1992); a Convenção Interamericana para Prevenir, Punir e Erradicar a Violência contra a Mulher (1995); o Protocolo à Convenção Americana referente aos Direitos Econômicos, Sociais e Culturais, Protocolo de San Salvador (1996); a Convenção Interamericana para a Eliminação de todas as formas de Discriminação contra Pessoas Portadoras de Deficiência (2001); o Estatuto de Roma, que cria o

\footnotetext{
${ }^{37}$ CANÇADO, Antonio Augusto Trindade. A Proteção Internacional dos Direitos Humanos: fundamentos jurídicos e instrumentos básicos. São Paulo: Saraiva, 1991, (p.234).
} 
Tribunal Penal Internacional (2002); o Protocolo Facultativo à Convenção sobre a Eliminação de todas as formas de Discriminação contra a Mulher (2002).

O Brasil ratificou ainda, a Convenção/OIT n. 155, promulgada através do Decreto n. 1.264 de 29 de setembro de 1994. Tal Convenção prevê que todo o país ao ratificá-la, deverá formular e implementar uma política nacional coerente em matéria de segurança e saúde dos trabalhadores, com o objetivo de prevenir acidentes e danos à saúde, reduzindo ao mínimo as causas dos riscos existentes no meio ambiente de trabalho. O documento estabelece também, que o controle da aplicação das leis e dos regulamentos relativos à segurança, à higiene e ao meio ambiente de trabalho, deverá estar assegurado por um sistema de inspeção das leis e dos regulamentos. Nesse sentido, a Convenção/OIT de n. 81, devidamente ratificada pelo Brasil, através do Decreto n. 9.5461 de 1997, preceitua que ao sistema de inspeção do trabalho incumbirá assegurar a aplicação das disposições legais relativas às condições de trabalho e à proteção dos trabalhadores no exercício de sua profissão, em especial, no que se refere à segurança, higiene e bem estar. A Convenção/OIT $\mathrm{n}^{\circ} 119$, também ratificada pelo Brasil e promulgada através do Decreto. 1.255 de 29 de setembro de 1994, estipula que a venda e locação de máquinas cujos elementos perigosos estiverem desprovidos de dispositivos de proteção apropriados, deverão ser proibidas pela legislação nacional, ou então, impedidas por outras medidas igualmente eficazes.

Toda esta legislação levou a doutrina especializada a deitar um olhar mais aprofundado nas atividades do papel da fiscalização do trabalho, que já dissemos anteriormente é executada através do Ministério do Trabalho e Emprego. É necessário destacar o artigo $626^{38}$ da CLT que impõe às autoridades competentes do MTE, ou

\footnotetext{
${ }^{38}$ CLT. Do Processo de Multas Administrativas. Capitulo I - Da Fiscalização, da Autuação e da Imposição de multas. Art. 626 - Incumbe às autoridades competentes do Ministério do Trabalho,
} 
àquelas que exerçam funções delegadas, a fiscalização do fiel cumprimento das normas de proteção ao trabalho. Ainda, a Lei n. $10.593^{39}$ de 06 de dezembro de 2002, revela que está dentre as atribuições do cargo de Auditor Fiscal do Trabalho assegurar em todo o território nacional, o cumprimento das disposições legais e regulamentares, inclusive aquelas relacionadas à segurança e à medicina no trabalho no âmbito as relações laborais. Assim, o cumprimento das normas que garantem a redução dos riscos inerentes ao trabalho no Brasil, depende da eficácia e da eficiência da fiscalização trabalhista.

O presente estudo tem como escopo basilar estudar o assédio e a violência no ambiente de trabalho e as formas de prevenção, considerando o assédio um comportamento caracterizado, muitas vezes, como rotina de humilhações indiretas sofridas pelo trabalhador e que afeta, sobremaneira, a sua dignidade. Tal conduta leva a uma aterrorizante degradação psíquica e emocional que viola um dos princípios fundamentais do Estado Democrático de Direito e atenta contra um direito humano e fundamental.

\subsection{Os Direitos Fundamentais do Trabalhador na Ordem}

\section{Jurídica Espanhola}

Com o objetivo de verificar como o ordenamento jurídico espanhol recepciona os direitos do trabalhador expressos na ordem jurídica internacional,

Indústria e Comercio, ou àquelas que exerçam funções delegadas, a fiscalização do fiel cumprimento das normas de proteção ao trabalho. Parágrafo único - Os fiscais dos Institutos de Seguro Social e das entidades paraestatais em geral dependentes do Ministério do Trabalho, Indústria e Comércio serão competentes para a fiscalização a que se refere o presente artigo, na forma das instruções que forem expedidas pelo Ministro do Trabalho, Indústria e Comércio.

${ }^{39}$ Lei 10.593/2002 que dispõe sobre a reestruturação da Carreira Auditoria do Tesouro Nacional, que passa a denominar-se Carreira Auditoria da Receita Federal - ARF, e sobre a organização da Carreira Auditoria-Fiscal da Previdência Social e da Carreira Auditoria-Fiscal do Trabalho, e dá outras providências. Disponível em:< http://www.planalto.gov.br/ccivil_03/LEIS/2002/L10593.htm>. Acesso em 23.10.2009. 
buscamos analisar a doutrina considerando a discussão, sobre os direitos fundamentais e a dignidade do homem que trabalha à luz da Constituição espanhola de 1978. Grande parte, entende que um princípio não determina as condições que tornam sua aplicação necessária, ao contrário, estabelece uma razão e um fundamento que impulsiona o intérprete numa direção, mas, que não reclama uma decisão específica ou única. Assim, o direito ao trabalho e a dignidade do trabalhador são considerados princípios jurídicos. Para $\mathrm{ALEXY}^{40}$, os princípios são normas que ordenam que algo seja realizado na maior medida possível dentro das possibilidades jurídicas reais existentes e que, portanto, são mandatos de otimização que se caracterizam porque podem cumprir-se em diferentes graus. Acrescenta ainda que, a medida devida de seu cumprimento não só depende das possibilidades reais, senão também, das jurídicas.

A constituição Espanhola traz em seu preâmbulo, uma declaração de princípios, ou seja, a intenção de garantir a convivência conforme uma ordem econômica e social justa. Prevê em seu artigo $1^{041}$ que a Espanha é um Estado social e Democrático de Direito, afirmando os valores da convivência e da dignidade humanas. Conjuga em seu artigo 10 o valor da dignidade da pessoa e os direitos inalienáveis que lhes são inerentes, como o livre desenvolvimento da personalidade, o respeito à lei e aos direitos dos demais, considerando estes fundamentos da ordem política e da paz social. Esse preceito, é tido como um direito subjetivo, um verdadeiro princípio dirigido aos poderes do Estado que deve guiar sua atuação. Tal consideração está prevista no artigo 53.2, quando proclama o denominado procedimento de amparo judicial e constitucional para proteger os cidadãos contra qualquer tipo de discriminação por razão de

\footnotetext{
${ }^{40}$ ALEXY, Robert. Teoria de los Derechos Fundamentales. $2^{\text {a }}$ edición, Madrid: Centro de Estudios Políticos y Constitucionales, 2007, (p.69).

${ }^{41}$ Constitución Española de 1978. Artigo 1. España se constituye en un Estado social y democrático de Derecho, que propugna como valores superiores de su ordenamiento jurídico la libertad, la justicia, la igualdad y el pluralismo político. Disponível em: 〈http://www.boe.es〉. Acesso em 30.11.2009.
} 
nascimento, raça, sexo, religião, opinião ou qualquer outra condição ou circunstância pessoal ou social.

Nesse sentido, a afirmação constitucional sobre a dignidade da pessoa como fundamento da ordem política e da paz social, constitui um preceito de prioridade dos seres humanos frente aos poderes públicos. Considera então, que nenhuma pessoa pode ser tratada à margem da sua condição de humana. Ademais, são os poderes públicos que devem dar especial atenção aos seres humanos e não ao contrário. Tal reflexão é possível realizar quando se lê o Capitulo III da CE que se refere aos direitos e liberdades do cidadão.

No âmbito laboral, a vulneração dos direitos fundamentais se constitui quando as atitudes do empresário contrariam o artigo 35.1 da CE que diz respeito à livre eleição do trabalho ou do oficio, a promoção através do trabalho e a remuneração suficiente para satisfazer suas necessidades e de sua família, e que, nenhum caso, deve haver discriminação por razão de sexo. Também o artigo 15 diz que todos tem direito a vida, a integridade física e moral e ninguém será submetido a tortura nem a penas ou tratos desumanos ou degradantes. No mesmo diploma legal, em relação a integridade moral destaca-se o artigo 18.1 no que respeita a honra, a intimidade pessoal e familiar e a imagem, tidos como direitos fundamentais.

Em relação aos direitos sociais é importante salientar que eles são os que garantem universalmente a todos os cidadãos e não por caridade ou política assistencial, o acesso aos meios necessários para que possam ter condição de vida digna. Assim, os poderes públicos assumem a responsabilidade de proporcionar as prestações ou serviços adequados para suprir suas necessidades vitais, considerando também, aquelas relacionadas ao trabalho tais como: a assistência frente ao desemprego; o afastamento 
remunerado do trabalho por motivo de doença; o direito a aposentadoria entre outros. Os trabalhadores, através dos sindicatos, adquirem uma série de direitos sociais, como podemos constatar no artigo 28 da CE. Ela prevê que todos têm o direito de sindicalizar-se livremente, reconhecendo o direito de greve na defesa dos interesses dos trabalhadores e a negociação coletiva.

No que respeita ao artigo 43.1 da $\mathrm{CE}$ afirma que se reconhece o direito à proteção à saúde. Pode se entender esse direito como um direito a proteção à saúde ou um direito a saúde. Se escolhermos essa segunda interpretação, podemos afirmar que, o direito à saúde exige um meio ambiente propício e saudável, ao passo que o direito de proteção à saúde requer que o Estado mobilize políticas e mecanismos suficientes e capazes de proporcionar ao cidadão atendimento em caso de enfermidades. Esse direito tem duas vertentes: uma individual que se traduz no direito da pessoa à proteção e que compromete os poderes públicos a tutelá-la e outro em relação ao meio ambiente em que está inserido, onde podemos afirmar que compete, no caso do presente estudo, as empresas e os empresários e demais atores sociais a proteger. Essas afirmações também são válidas para o artigo 40.2 do mesmo diploma legal, onde se impõe aos poderes públicos o dever de velar pela seguridade e higiene no trabalho, garantir descanso necessário mediante a limitação da jornada de trabalho, das férias remuneradas e da promoção de centros adequados de atendimento ao trabalhador.

É importante ressaltar que é o texto constitucional esclarece a proibição da discriminação no trabalho, remetendo sua regulamentação para a Lei denominada de Estatuto dos Trabalhadores (ET). O Estatuto é considerado a norma básica de regulamentação das relações de trabalho da Espanha e demonstra que incorporou o princípio da dignidade da pessoa humana nas relações laborais. 
$\mathrm{O}$ direito à intimidade se configura como um direito fundamental e vinculado à própria personalidade da pessoa. $\mathrm{O}$ direito à personalidade deriva do conceito mais amplo da dignidade da pessoa que o artigo 10 da $\mathrm{CE}$ reconhece, implicando no respeito ao direito à intimidade. Esse, é um direito de dimensão pessoal e familiar que também deve ser objeto de especial cuidado no campo das relações laborais. O ET demonstra que, assimilou o direito à intimidade no campo laboral, cabendo mencionar o artigo 4.2 e) ${ }^{42}$ que reconhece o direito do trabalhador a ser respeitado em sua intimidade e em sua dignidade. Manter salvaguardado o direito do trabalhador frente ao assédio sexual que engloba especificadamente o respeito à intimidade e consideração devida à dignidade do trabalhador, faz com que o empresário seja obrigado a não agir contra esse direito. Esse artigo, aparece atualmente reforçado pelo conteúdo do artigo 184 do Código Penal que recebeu nova redação dada pela Lei Orgânica 11/1999 de 30 de abril ${ }^{43}$, e pelo artigo 8.13 do Real Decreto Legislativo n. 5/2000 de 4 de agosto que considera infração muito grave quando o assédio sexual se produz dentro de um âmbito em que o trabalhador esteja exercendo atividade sob direção empresarial.

\footnotetext{
${ }^{42}$ Estatuto de los Trabajadores. Artículo 4. Derechos laborales 2. En la relación de trabajo, los trabajadores tienen derecho: e) Al respeto de su intimidad y a la consideración debida a su dignidad, comprendida la protección frente a ofensas verbales o físicas de naturaleza sexual.

${ }^{43}$ Ley Orgánica 11/1999, de 30 de abril. Art. 184. Del Acoso Sexual: 1. El que solicitare favores de naturaleza sexual para sí o para un tercero, en el ámbito de una relación laboral, docente o de prestación de servicios, continuada o habitual, y con tal comportamiento provocar a la víctima una situación objetiva y gravemente intimidatoria, hostil o humillante, será castigado, como autor de acoso sexual, con la pena de arresto de seis a doce fines de semana o multa de tres a seis meses. 2. Si el culpable de acoso sexual hubiera cometido el hecho prevaliéndose de una situación de superioridad laboral, docente o jerárquica, o con el anuncio expreso o tácito de causar a la víctima un mal relacionado con las legítimas expectativas que aquélla pueda tener en el ámbito de la indicada relación, la pena será de arresto de doce a veinticuatro fines de semana o multa de seis a doce. 3. Cuando la víctima sea especialmente vulnerable, por razón de su edad, enfermedad o situación, la pena será de arresto de doce a veinticuatro fines de semana o multa de seis a doce meses en los supuestos previstos en el apartado 1, y de prisión de seis meses a un año en los supuestos previstos en el apartado 2 del presente artículo. Lei publicada no BOE no 104 de 01.05.1999. Acesso em 23.02.2009.
} 
Destacamos também, a importância da Ley Orgânica 003/2007 de 22 de março para la igualdad efectiva de mujeres y hombres $(\mathrm{LOIMH})^{44}$. Em seu artigo $7^{\circ}$ a norma trata do assédio sexual assim definindo: "Sin perjuicio de lo establecido en el Código Penal, a los efectos de esta Ley constituye acoso sexual cualquier comportamiento, verbal o físico, de naturaleza sexual que tenga el propósito o produzca el efecto de atentar contra la dignidad de una persona, en particular cuando se crea un entorno intimidatorio, degradante u ofensivo".

A Lei de igualdade também tem por objetivo fazer valer a igualdade de tratamento e oportunidades entre mulheres e homens, em especial, em relação a não discriminação contra a mulher seja qual for a situação ou circunstância em que ela se encontre, nas esferas política, civil, laboral, econômica, social e cultural. Estabelece princípios para a atuação dos poderes públicos, regula os direitos das pessoas físicas e jurídicas, tanto públicas como privadas e prevê medidas para eliminar e corrigir toda e qualquer forma de discriminação por razão de sexo. Define o assédio por razão de sexo em seu artigo $7^{\circ}$, dizendo que: "Constituye acoso por razón de sexo cualquier comportamiento realizado en función del sexo de una persona, con el propósito o el efecto de atentar contra su dignidad y de crear un entorno intimidatorio, degradante $u$ ofensivo.” Percebemos que o legislador refere-se à pessoa, quer dizer que, tanto o homem quanto a mulher poderão vir a ser vítimas de assédio por razão de sexo.

No que refere ao Estatuto dos Trabalhadores (ET) o artigo 50 estabelece que a extinção do contrato de trabalho por parte do trabalhador pode ser realizada se o empresário deixar de cumprir de forma grave qualquer das cláusulas por ele firmada no

\footnotetext{
${ }^{44}$ Ley Orgánica 03/2007 de 22 de marzo: "para la igualdad efectiva de mujeres y hombres". Publicada no $\mathrm{BOE} \mathrm{n}^{\circ} 71$ de 23/03/2007. Acesso em 23.02.2009.
} 
contrato. Esse comportamento empresarial pode ser percebido como a falta de cumprimento da obrigação que impõe a lei de velar pelo direito que tem todo o trabalhador à sua integridade física, previsto no artigo 4.2 d) do mesmo Documento. Ou ainda, a respeito da intimidade e da consideração de vida à sua dignidade como reza o 4.2 e também, a realizar uma política adequada de segurança no trabalho são razões de extinção do contrato laboral. O comportamento empresarial exposto, também vai contra o artigo 8.11 da Ley sobre Infracciones y Sanciones en el Orden Social (LISOS), aprovada pelo Real Decreto 5/2000 de 04 de agosto, por ser considerado ato contrário ao respeito à intimidade e à dignidade do trabalhador ${ }^{45}$.

\subsection{A Proteção à Segurança e à Saúde do Trabalhador no Brasil e na}

\section{Espanha: um quadro comparativo}

Com o objetivo compreender a proteção à segurança e à saúde do trabalhador como um direito a ser garantido pelas Instituições, dissemos que em um contexto histórico a origem do Direito do Trabalho, tinha a finalidade de promover a dignidade das pessoas ou, mais especificamente, daqueles que trabalhavam nas indústrias e nas fábricas. Assim, esta ciência nasceu com o objetivo de favorecer a proteção à vida e à saúde dos trabalhadores e por isso, foi considerado um ramo do Direito sadio. As normas de Direito do Trabalho objetivavam o cumprimento de obrigações negativas em relação ao trabalhador e ao Estado, que proibiam a prática de atos que pudessem colocar em risco a integridade física e mental do trabalhador, mas também, trouxeram as obrigações positivas como as de implementar providências

\footnotetext{
${ }^{45}$ LISOS - Articulo 8 - Infracciones muy graves. 11. Los actos del empresario que fueren contrarios al respeto de la intimidad y consideración debida a la dignidad de los trabajadores. Disponível em. http://www.ugt.es>.Acesso em: 30.12.2009.
} 
necessárias à preservação e proteção da saúde do trabalhador por parte do Estado. É por isso, que existem as chamadas medidas de prevenção de enfermidades.

Entre as estratégias adotadas pela maior parte da legislação brasileira, existem duas que merecem destaque:

a) A proibição do exercício de atividades insalubres e perigosas;

b) A compensação financeira para quem exerce essas atividades.

A primeira dessas medidas seria a ideal para evitar os riscos à saúde do trabalhador, porém, nem sempre é possível implementá-la. Algumas atividades, embora nocivas à saúde e à segurança do trabalhador, são necessárias e, portanto, não podem ser deixadas de lado quanto à inspeção e fiscalização pelo poder público. A segunda medida de proteção, busca tentar compensar os riscos da primeira, e foi adotada pela CLT no Brasil através do pagamento dos adicionais de insalubridade e periculosidade. É claro que, nesse aspecto, estamos falando apenas de riscos visíveis, mais propriamente os físicos, e, em nenhuma hipótese nos referimos às questões causadoras de riscos psicológicos, como por exemplo, ao assédio ou à violência moral.

Ainda, no que respeita a essa temática, a utilização dos EPI's, assim considerados os equipamentos utilizados de forma individual pelo trabalhador para protegê-lo dos possíveis riscos que ameaçam sua saúde e segurança, buscam evitar possíveis danos físicos no ambiente laboral. $\mathrm{O}$ uso de tais equipamentos, não exclui a aplicação das medidas coletivas de proteção, como a orientação através de profissionais especializados no sentido de ensinar a utilizar os equipamentos de segurança de maneira correta e a aprendizagem corporativa por meio de reuniões, cursos e oficinas pedagógicas que podem ocorrer durante o trabalho. 
A CLT em seu artigo 191 prevê que, cabe ao empresário adotar medidas capazes de neutralizar ou de eliminar a insalubridade do ambiente laboral. No artigo $166^{46}$ da mesma norma, revela que cabe ao empresário fornecer aos empregados de forma gratuita os EPI's. O TST, através da Súmula nº 289 revela que o simples fornecimento do aparelho de proteção pelo empregador não o exime do pagamento do adicional de insalubridade, cabendo-lhe tomar as medidas que conduzam à diminuição ou eliminação da nocividade, dentre as quais, aquelas relativas ao uso efetivo do equipamento pelo empregado. Também é relevante afirmar, que a própria CF do Brasil em seu artigo 21 XXIV, dispõe que a União (leia-se Estado Federal) deverá organizar, manter e executar a inspeção do trabalho, no âmbito do Poder Executivo Federal, tarefa essa que incumbe ao MTE, como já comentamos anteriormente.

Outra medida registrada pela história e que foi trazida pela Encíclica Rerum Novarum de 1891, onde o Papa leão XIII já exaltava a necessidade de respeitar a limitação das forças do trabalhador, defendendo que não era justo nem humano exigir do homem tanto trabalho a ponto de fazê-lo, pelo excesso de fadiga, embrutecer o espírito e enfraquecer o corpo, resulta na redução da jornada de trabalho. Para muitos doutrinadores essa medida também pode ser considerada uma saída ética para enfrentar a questão do risco laboral, compensando o desgaste com o período maior de descanso.

A violação das normas de proteção ao ambiente laboral por parte dos empresários gera responsabilidade pelas doenças e pelos acidentes de trabalho nos

\footnotetext{
${ }^{46}$ CLT. Art. 166 - A empresa é obrigada a fornecer aos empregados, gratuitamente, equipamento de proteção individual adequado ao risco e em perfeito estado de conservação e funcionamento, sempre que as medidas de ordem geral não ofereçam completa proteção contra os riscos de acidentes e danos à saúde dos empregados.
} 
termos do já ressaltado artigo 225 da Carta brasileira e dos artigos $186^{47}$ e $927^{48}$ do Código Civil em vigor, independentemente do trabalhador ter recebido o beneficio previdenciário devido. Os Tribunais entendem, que a culpa da empresa e da prestadora de serviço é presumida, cabendo a elas provar o contrário. Precisamos destacar, que quando o empregador exerce atividades de risco como as insalubres e as perigosas que, como já vimos, afetam o meio ambiente laboral e aqueles que nele trabalham o dever de indenizar os danos causados a terceiros e ao próprio trabalhador não exige culpa, como prevê o artigo 927, parágrafo único do Código Civil. MELO $^{49}$, citando Nelson Nery Junior, alega que a responsabilidade civil por danos ao meio ambiente do trabalho e a saúde do trabalhador tem uma tríplice natureza:
a) De reparação;
b) De sanção;
c) Pedagógica para os atuais e potenciais degradadores.

Aqui, aparece a intenção educativa da norma e tanto faz se o ato é legal ou ilegal, o que importa, é a existência de um dano para que o seu causador arque com os prejuízos dele decorrentes, respondendo assim, independentemente de culpa ou da intenção de causar prejuízo ao meio ambiente.

No Brasil, há previsão legal do Serviço Especializado em Engenharia de Segurança e Medicina do Trabalho (SESMT), regulamentado pela Portaria $n^{\circ} 3.214$ de 08 de junho de 1978, pela NR4, e pelo artigo 162 da CLT que visa assegurar, promover e proteger a saúde e a integridade do trabalhador no local de trabalho. Também temos a

\footnotetext{
${ }^{47}$ Código Civil. Art. 186. Aquele que, por ação ou omissão voluntária, negligência ou imprudência, violar direito e causar dano a outrem, ainda que exclusivamente moral, comete ato ilícito.

${ }^{48}$ Art. 927. Aquele que, por ato ilícito (arts. 186 e 187), causar dano a outrem, fica obrigado a repará-lo.

${ }^{49}$ MELO. Raimundo Simão de. Direito Ambiental do Trabalho e a Saúde do Trabalhador. São Paulo: LTr, 2008, (p.340).
} 
Comissão Interna de Prevenção de Acidentes $(\mathrm{CIPA})^{50}$, que tem por objetivo observar e relatar as condições de riscos no ambiente de trabalho, solicitando medidas para reduzir até eliminar os riscos existentes e/ou neutralizá-los, contribuindo para a preservação da saúde e da integridade física dos trabalhadores e daqueles que interagem com a empresa.

\section{O artigo $49^{51}$ da CE dispõe a respeito das pessoas com deficiências}

físicas, sensoriais ou psíquicas e afirma que elas receberão atenção especializada. O artigo $51^{52}$ é dedicado à saúde dos consumidores, mas ainda há outros artigos intimamente ligados ao tema, como os artigos $41^{53}$, o $45^{54}$ que dão lugar à conservação

\footnotetext{
${ }^{50}$ A Comissão Interna de Prevenção de Acidentes (CIPA) é um instrumento que os trabalhadores dispõem para tratar da prevenção de acidentes do trabalho, das condições do ambiente do trabalho e no que refere a sua segurança e saúde. O órgão é regulamentado pela CLT nos artigos 162 a 165 e pela Norma Regulamentadora 05 (NR-5), contida na portaria 3.214 de 08.06.78 baixada pelo Ministério do Trabalho. Este instrumento de prevenção surgiu a partir de uma sugestão de trabalhadores de diversos países reunidos na Organização Internacional do Trabalho (OIT). A recomendação foi a criação de Comitês de seguridade para cada grupo de 20 trabalhadores. A função principal é preservar a integridade do trabalhador. A organização da CIPA é obrigatória nos locais de trabalho seja qual for sua característica comercial, industrial, bancária, com ou sem fins lucrativos, filantrópica ou educativa e empresas públicas. É composta por representantes do empresário e dos empregados. Os representantes do empresário são escolhidos pelo próprio, enquanto que os dos empregados são eleitos em votação secreta representando, obrigatoriamente, os setores de maior risco de acidentes e com maior número de funcionários. Informações obtidas no endereço: <http://www.cipanet.com.br/index.asp>. Acesso em 23.10.2009.

${ }^{51}$ CE - Art. 49. Los poderes públicos realizarán una política de previsión, tratamiento, rehabilitación e integración de los disminuidos físicos, sensoriales y psíquicos, a los que prestarán la atención especializada que requieran y los ampararán especialmente para el disfrute de los derechos que este Título otorga a todos los ciudadanos. 1. Los poderes públicos garantizarán la defensa de los consumidores y usuarios, protegiendo, mediante procedimientos eficaces, la seguridad, la salud y los legítimos intereses económicos de los mismos. 2. Los poderes públicos promoverán la información y la educación de los consumidores y usuarios, fomentarán sus organizaciones y oirán a éstas en las cuestiones que puedan afectar a aquéllos, en los términos que la Ley establezca. 3. En el marco de lo dispuesto por los apartados anteriores, la Ley regulará el comercio interior y el régimen de autorización de productos comerciales.

${ }^{52}$ CE - Art. 51. 1. Los poderes públicos garantizarán la defensa de los consumidores y usuarios, protegiendo, mediante procedimientos eficaces, la seguridad, la salud y los legítimos intereses económicos de los mismos. 2. Los poderes públicos promoverán la información y la educación de los consumidores y usuarios, fomentarán sus organizaciones y oirán a éstas en las cuestiones que puedan afectar a aquéllos, en los términos que la Ley establezca. 3. En el marco de lo dispuesto por los apartados anteriores, la Ley regulará el comercio interior y el régimen de autorización de productos comerciales.

${ }^{53} \mathbf{C E}$ - Art. 41. Los poderes públicos mantendrán un régimen público de Seguridad Social para todos los ciudadanos, que garantice la asistencia y prestaciones sociales suficientes ante situaciones de necesidad, especialmente en caso de desempleo. La asistencia y prestaciones complementarias serán libres.

${ }^{54} \mathbf{C E}$ - Art. 45. 1. Todos tienen el derecho a disfrutar de un medio ambiente adecuado para el desarrollo de la persona, así como el deber de conservarlo. 2. Los poderes públicos velarán por la utilización racional de todos los recursos naturales, con el fin de proteger y mejorar la calidad de la vida y defender y restaurar el medio ambiente, apoyándose en la indispensable solidaridad colectiva. 3. Para quienes violen
} 
e à proteção do meio ambiente e a utilização adequada dos recursos naturais. Já o artigo 43 afirma que "se reconece el derecho a la protección de la salud". Segundo BENAVIDES ${ }^{55}$, este direito à proteção à saúde tem duas vertentes, uma individual que se traduz no direito de proteção a pessoa que compete aos poderes públicos à tutela sobre a base de que é um estado de completo bem estar físico, psíquico e social, e outra, coletiva, como direito da comunidade à saúde pública.

Com respeito à saúde pública e as medidas que os poderes públicos devem tomar em relação a ela, é possível destacar a Ley General de Sanidad (LGS $14 / 1986)^{56}$, como desenvolvimento normativo do artigo 43 da CE, consagrando o direito de todas as pessoas à proteção à saúde integral e em condições de igualdade ${ }^{57}$. Podemos perceber, que o direito à saúde é considerado aqui, um princípio da política social e econômica, sendo então um direito fundamental. A mesma importância se dá ao artigo 40.2, que reconhece o direito à saúde laboral ou a segurança e higiene no trabalho. Preceitos esses, que obrigam o Estado a realizar ações necessárias para garantir a vida, a integridade física e a saúde de todas as pessoas e dos trabalhadores.

Ainda na Espanha, é importante destacar a Lei 31/1995 de Prevención de Riesgos Laborales $(L P R L)^{58}$ que obedece a um mandato Constitucional para

lo dispuesto en el apartado anterior, en los términos que la Ley fije se establecerán sanciones penales o, en su caso, administrativas, así como la obligación de reparar el daño causado.

${ }^{55}$ BENAVIDES, F.C. RUIZ FRUTOS y A.M.GARCÍA: Salud laboral: conceptos y técnicas para la prevención de riesgos laborales. Barcelona, Masson, 1997, (p.28).

${ }^{56}$ Lei Publicada no BOE no 102 de 29.04.1986.

${ }^{57}$ LGS 14/1986 Artigo 1.2 (universalidade) artigo 3.2 (assistência sanitária) 3.3 (política sanitária). O artigo 10.1, reconhece o direito que todas as pessoas tem frente as administrações públicas santárias, afirmando: "Al respeto a su personalidad, dignidad humana e intimidad, sin que pueda ser discriminado por razones de raza, de tipo social, de sexo, moral, económico, ideológico, político o sindical”. O artigo 16 (controle e melhora da qualidade da assitência sanitária) e o artigo 21 (proteção integral à saúde dos trabalhadores). Lei publicada no BOE nº 102 de 29.04.1986. Acesso em 25.10.2009.

${ }^{58}$ Sobre a referida lei, MARTÍN HERNÁNDEZ, no libro: El derecho de los trabajadores a la seguridad y salud en el trabajo. Madrid: Consejo Económico y Social, 2006, p.9, afirma que: "A LPRL no regula sólo el derecho de los trabajadores a la seguridad y salud en el trabajo y el correlativo deber de su empresario de garantizarlo, sino que, además impone obligaciones en materia de seguridad y salud en el trabajo a otros sujetos. Por un lado establece cuáles son las funciones que corresponde cumplir a los 
desenvolver uma política de proteção à saúde dos trabalhadores mediante a prevenção de riscos laborais, trazendo também, as diferentes ações preventivas em coerência com as decisões da União Européia. Destacamos, o artigo 4.3 que considera como danos derivados do trabalho "las enfermedades, patologias y lesiones sufridas con motivo $u$ ocasión del trabajo," englobando as doenças psíquicas. Reconhecemos a dificuldade de aplicação da norma jurídica a certas doenças psíquicas como, por exemplo, ao estresse laboral, as enfermidades causadas pelo assédio e a síndrome do queimado (burnout). Quanto a intervenção dos mecanismos preventivos à proteção da saúde psíquica do trabalhador e dos princípios de ação preventiva não ocorre por falta de uma normativa específica, aplicam-se os princípios gerais da LPRL, em particular os dispostos nos artigos 14, 15, 16 e 25. A respeito dessa temática dedicaremos um capítulo específico.

No que refere à segurança e à saúde do trabalhador no âmbito Europeu, tem se aprovado uma ampla variedade de medidas sobre o tema com base no artigo 137 do Tratado da $\mathrm{CE}^{59}$. As Diretivas Européias, diferentemente das Orientações do

Poderes Públicos, y por otro impone determinados deberes a otros sujetos privados distintos del propio empresario, fundamentalmente a los trabajadores y a sus representantes en la empresa o centro de trabajo donde los trabajadores de otro empresario ejecutan su prestación de servicios y a los fabricantes, importadores y suministradores de equipos y medios de trabajo."

${ }^{59}$ Tratado Constitutivo de la Comunidad Europea. Titulo IX - Política Social, de Formación Profesional y de Juventud. Disposiciones Sociales: Articulo 137. 1. Para la consecución de los objetivos del artículo 136, la Comunidad apoyará y completará la acción de los Estados miembros en los siguientes ámbitos: La mejora, en concreto, del entorno de trabajo, para proteger la salud y la seguridad de los trabajadores; Las condiciones de trabajo; La seguridad social y la protección social de los trabajadores; La protección de los trabajadores en caso de rescisión del contrato laboral; La información y la consulta a los trabajadores; La representación y la defensa colectiva de los intereses de los trabajadores y de los empresarios, incluida la cogestión, sin perjuicio de lo dispuesto en el apartado 5; Las condiciones de empleo de los nacionales de terceros países que residan legalmente en el territorio de la Comunidad; La integración de las personas excluidas del mercado laboral, sin perjuicio del artículo 150; La igualdad entre hombres y mujeres por lo que respecta a las oportunidades en el mercado laboral y al trato en el trabajo; La lucha contra la exclusión social; La modernización de los sistemas de protección social, sin perjuicio de la letra c) 2. A tal fin, el Consejo: Podrá adoptar medidas destinadas a fomentar la cooperación entre los Estados miembros mediante iniciativas para mejorar los conocimientos, desarrollar el intercambio de información y de buenas prácticas, promover fórmulas innovadoras y evaluar experiencias, con exclusión de toda armonización de las disposiciones legales y reglamentarias de los Estados miembros; Podrá adoptar, en los ámbitos mencionados en las letras a) a i) del apartado 1, mediante directivas, las disposiciones mínimas que habrán de aplicarse progresivamente, teniendo en cuenta las condiciones y reglamentaciones técnicas existentes en cada uno de los Estados miembros. Tales directivas evitarán establecer trabas de carácter administrativo, financiero y jurídico que 
Mercosul são vinculantes e os Estados membros, devem, no caso específico da Espanha incluí-las em sua legislação nacional. Elas estabelecem princípios fundamentais, como o princípio da avaliação de riscos, a prevenção e a responsabilidade do empresário e do empregado. A Diretiva Marco 89/391 ${ }^{60}$ de 1989 relativa à aplicação de medidas para promover a melhora da segurança e da saúde do trabalhador no ambiente de trabalho, na exposição de motivos, salienta o seguinte: "Considerando que hay que lamentar todavía demasiados accidentes de trabajo y enfermedades profesionales; que se deben tomar o mejorar, sin más tardar, medidas preventivas para preservar la seguridad y la salud de los trabajadores, de manera que se garantice un mejor nivel de protección." $\mathrm{O}$ objetivo do Documento é garantir uma proteção mais eficaz com medidas dirigidas à prevenção dos acidentes de trabalho e enfermidades profissionais, mediante informação, consulta, participação e formação dos trabalhadores e seus representantes. Uma das obrigações dos empresários citada na Diretiva, é a de que ele deve realizar avaliações periódicas dos riscos profissionais e a eleição de equipes de trabalho capazes de organizar os serviços de prevenção. Nesse sentido, consideramos que as medidas preventivas no local de trabalho e o respectivo monitoramento dos possíveis acidentes ou enfermidades laborais, são capazes de minimizar os riscos a que os trabalhadores encontram-se sujeitos. Assim, o ordenamento jurídico espanhol busca construir uma proteção à integridade física do trabalhador na realização de suas tarefas.

obstaculicen la creación y el desarrollo de pequeñas y medianas empresas. Disponível em: <http://europa.eu/legislation_summaries/index_es.htm>. Acesso em 25.10.2009.

${ }^{60}$ Diretiva publicada no Diário Oficial L 183 de 29.06.1989. 


\section{CAPÍTULO II}

\section{OS RISCOS LABORAIS E PSICOSSOCIAIS NO AMBIENTE DO \\ TRABALHO}

\subsection{As Enfermidades Decorrentes do Ambiente Laboral}

O objetivo desse capítulo é conhecer as enfermidades decorrentes do ambiente de trabalho, suas causas e consequências, compreendendo o processo de criminalização do assédio como um risco laboral e psicossocial e as ações preventivas realizadas pelas empresas e pelos sindicatos na tentativa de inibir essa conduta.

O trabalho é considerado uma fonte de aquisição econômica, mas também, percebido como um momento de convívio social necessário para a valorização do indivíduo na sociedade. Quando realizado em condições ideais pode ser gratificante e até saudável, pois, permite ao homem o desenvolvimento de suas aptidões intelectuais e físicas fazendo com que ele se sinta parte integrante na construção do tecido social. No entanto, quando realizado de maneira incorreta ou em locais que expõe os trabalhadores a riscos, pode trazer sérios problemas a sua vida e a sua saúde.

Atualmente, temos visto que as enfermidades e os riscos psicossociais provenientes do ambiente de trabalho tem sido motivo de grande preocupação de estudiosos e pesquisadores. Os riscos psicossociais estão intimamente ligados às condições de trabalho. De acordo com o Instituto Sindical de Trabajo, Ambiente y Salud 
$(\text { ISTAS })^{61}$, os riscos psicossociais prejudicam a saúde dos trabalhadores e trabalhadoras, causando estresse e, a longo prazo, doenças cardiovasculares, respiratórias, gastrointestinais, dermatológicas, endocrinológicas e até mentais.

O Estresse é definido como a soma das respostas físicas e mentais causadas por determinados estímulos externos que permitem ao indivíduo superar as exigências do meio. A enfermidade pode ser causada pela ansiedade e pela depressão devido à mudança brusca no estilo de vida e a exposição a um determinado ambiente, que leva a pessoa a sentir um determinado tipo de angústia. A OSHA estima que o estresse laboral é um dos principais problemas que os trabalhadores enfrentam, demonstrando que $50 \%$ a $60 \%$ dos afastamentos do trabalho estão relacionados com esse problema, gerando assim, o sofrimento humano e prejuízos para a economia das empresas e do mercado. Dentre os fatores mais comuns de estresse laboral, estão a falta de controle e a insegurança no trabalho, as demandas excessivas, as metas abusivas de resultados, a competitividade feroz, o medo do desemprego, o ritmo de trabalho, as exigências do meio e a falta de apoio de colegas e superiores.

A defesa da saúde como um direito fundamental das pessoas que trabalham, qualquer que seja o tipo de empresa ou setor e, ante as altas cifras de acidentes de trabalho e enfermidades, fez com que os Organismos internacionais preocupados com a questão em matéria de saúde, como a Organização Mundial de Saúde (OMS) demonstrassem em seus diversos Relatórios, que 75\% das pessoas que tem depressão nunca receberam um tratamento adequado e que a enfermidade pode ser ocasionada pelo estresse laboral. E ainda, chamam a atenção dos países emergentes para

\footnotetext{
${ }^{61}$ ISTAS - Instituto Sindical de Trabajo, Ambiente y Salud. É uma fundação autônoma de caráter técnico sindical, promovida pelas Comissões Obreiras espanholas (CCOO) objetivando impulsionar atividades de progresso social para a melhora das condições de trabalho, da proteção do meio ambiente e da promoção da saúde dos trabalhadores no âmbito de Estado Espanhol. Disponível em:<http://www.istas.net/web/index.asp?idpagina=1235>. Acesso em 03.12.2009.
} 
o estresse no local de trabalho e à influência de fatores socais na vida dos trabalhadores, associadas às constantes mudanças sociais como, por exemplo, a globalização, o aumento da economia informal e as mudanças bruscas que ocasionam ao ambiente de trabalho. A globalização como parte do processo de mudança social, traz consigo uma série de reformas e alterações na vida dos trabalhadores e das empresas, exigindo que eles executem mais tarefas em menos tempo e o índice de aproveitamento do tempo dedicado ao trabalho seja cada vez mais elevado.

O estresse laboral a que nos referimos, é definido como a soma das respostas mentais e físicas ou das reações fisiológicas que, uma vez intensificadas, transformam-se em reações emocionais negativas, aumentando consideravelmente o número de trabalhadores afastados do ambiente laboral e refletindo na vida das organizações. Lembramos que, resulta impossível expor de forma exaustiva todas as causas ou os fatores de risco que levam ao estresse laboral, embora sabemos, que existem certos trabalhos ou profissões que tem maiores índices de probabilidade por causa do ambiente e do tipo de atividade profissional desenvolvida. Alguns sintomas que os especialistas destacam como possíveis sinais de alerta são: dores musculares, dores de cabeça, esgotamento, irritabilidade, mudanças no sono, na alimentação e na vida sexual, podendo até causar transtornos físicos como doenças gastrointestinais, cardiovasculares e respiratórias, transtornos psicológicos como ansiedade, medos, fobias, consumo excessivo de álcool e drogas, depressão, transtornos afetivos, de personalidade e esquizofrenia.

A própria OMS revela que, as políticas públicas e as iniciativas das Organizações estão centradas quase que somente nos aspectos preventivos relacionados à saúde e à segurança dos trabalhadores negligenciando-se os riscos psicossociais. Um 
estudo importante sobre a gestão de riscos no ambiente de trabalho que leva em conta os aspectos psicossociais foi realizado pelo órgão regulador Britânico, Health and Safety Executive (HSE), em maio de 2007. O Documento, com 126 páginas, analisa a atuação de gestores no ambiente de trabalho e sua contribuição no cotidiano dos trabalhadores, mapeando a prevenção de riscos para a redução do estresse ocupacional ${ }^{62}$.

No preâmbulo da ata de constituição da OMS, a saúde é definida como um estado completo de bem estar físico, psíquico e social e não apenas como ausência de enfermidade. Como se pode observar trata-se de uma delimitação muito ampla no âmbito da saúde da pessoa que compreende, além dos aspectos relacionados à integridade física e a plenitude funcional do indivíduo, à saúde psíquica que pode traduzir-se em sentir-se bem consigo mesmo o que envolve, entre outros fatores, a eliminação de todas as formas de estresse. A qualidade de vida é um direito do trabalhador que o Estado Social deve garantir permitindo que o indivíduo possa desenvolver sua personalidade de forma tranquila. Assim, a fixação de um salário mínimo, a procura de um posto de trabalho digno para todo o cidadão baseado em uma política orientada ao pleno emprego, a atenção aos desempregados, aos anciãos, às crianças, aos deficientes mentais, e a outros grupos considerados desfavorecidos, acrescentando uma justa e equitativa distribuição de renda em todos os níveis para que se possa ter acesso aos bens culturais e obter informação para desenvolver idéias

\footnotetext{
${ }^{62} \mathrm{O}$ método para o estudo envolveu 216 empregados 166 gerentes de linha e 54 profissionais de Recursos Humanos nas áreas de educação, finanças, governo local, administração central e saúde. A emergente "Gestão de Competências para prevenir e reduzir o estresse no quadro de trabalho" identificou 19 competências relativas à gestão do estresse em trabalhadores. O estudo em inglês está disponível em: <http://www.hse.gov.uk/research/rrhtm/rr553.htm>. Acesso em 24.10.2009.
} 
inovadoras $^{63}$, deve ser o objetivo dos Estados que se auto denominam de Estados sociais.

Outra enfermidade decorrente do meio laboral é a Síndrome do Burnout, a palavra de origem inglesa, burn, significa "queimar" e out que quer dizer "fora", “exterior", entende-se por "queimar para fora", "consumir-se de dentro para fora", ou ainda "combustão completa". Atualmente, o termo é utilizado por especialistas em saúde mental para designar um estado avançado de estresse, cuja causa é exclusivamente o ambiente de trabalho. A enfermidade se caracteriza pelo estresse crônico, vivenciado por profissionais que trabalham em um ambiente pesado, hostil e dificultoso. A síndrome se efetiva no estágio mais avançado do estresse, caracterizado por um conjunto de sinais e sintomas de causas diversas podendo ser de ordem psicológica ou física. Os sintomas são variados, como o desânimo e a desmotivação com o trabalho podendo resultar em doenças psicossomáticas e levando o profissional à faltas frequentes no trabalho, ao afastamento temporário por motivo de doença e até, em casos extremos a aposentadoria por invalidez.

De acordo com o psicanalista e psicopedagogo CHAFIC JBEILI, a enfermidade apresenta quatro estágios de sintomas. No primeiro, a pessoa não tem vontade de ir trabalhar, apresentando um desânimo genérico em relação a sua atividade profissional, surgindo dores na região das costas e na cervical. No segundo estágio, a relação interpessoal com os colegas de trabalho começa a ficar tensa, surgindo pensamentos neuróticos de perseguição ou boicote por parte de colegas de trabalho ou

\footnotetext{
${ }^{63}$ Esses direitos configurados como Direitos Humanos de terceira geração apresentam-se na forma de direitos sociais, trazendo as seguintes características importantes: a formulação basicamente vinculada a idéia de igualdade e de dignidade; o caráter prestacional fortemente marcado pela implicação do Estado em agir e a presença de um conjunto de dificuldades reiteradamente destacadas pela doutrina, entre as quais se sobressai a sua efetividade por circunstâncias econômicas. SASTRE IBARRECHE, Rafael. $E l$ Derecho al Trabajo. Madrid: Trotta, 1996, (p.72).
} 
do chefe, as faltas ao trabalho são frequentes e as licenças médicas recorrentes. As habilidades do trabalhador começam a ficar comprometidas, ocorrendo erros operacionais constantes, lapsos de memória, doenças psicossomáticas, ingestão de bebidas alcoólicas para mascarar a angústia que sentem e o desprazer de viver são sinais do terceiro estágio. Num quarto estágio, o profissional pode ficar dependente do álcool ou das drogas, surgem pensamentos de autodestruição e suicídio, tornando inevitável o afastamento do trabalho ${ }^{64}$.

É importante salientar, que existem diferenças significativas entre o estresse laboral e a síndrome do burnout que, segundo estudiosos a síndrome é considerada como uma das possíveis respostas do impacto acumulativo do estresse laboral crônico ${ }^{65}$. O estresse laboral se caracteriza pela implicação nos problemas, pela hiperatividade emocional, pelo esgotamento, falta de energia, depressão (entendido aqui como reação para preservar as energias), podendo ter efeitos positivos em exposições moderadas. Já o burnout se caracteriza pela falta de implicação com os problemas, com a apatia emocional, com o esgotamento afeto à motivação e a energia psíquica, e se parece com a depressão, sendo semelhante a sensação de perda de ideais, só tem efeitos negativos ${ }^{66}$. Portanto, ainda que esses conceitos tenham uma relação estreita, não são idênticos.

\footnotetext{
${ }^{64}$ CHAFIC JBEILI recorda que esses sintomas apresentados são meramente informativos, e não apresentam de forma cabal a manifestação do burnout, podendo ocorrer diversas variações entre pessoas com o mesmo quadro sintomático. Informações retiradas da Cartilha que o psicanalista e psicopedagogo editou intitulada: Síndrome do Burnout em Professores: identificação, tratamento e prevenção, (2008). Ver mais sobre seu trabalho: <http://cursoschafic.com/combate_a_burnout.html >. Acesso em 03.12.2009. ${ }^{65} \mathrm{O}$ estresse laboral crônico se produz em um período prolongado de tempo, de maneira recorrente, contínuo e intenso. É mais frequente em ambientes laborais inadequados e quando existem situações de sobrecargas de trabalho ou à condições de trabalho precárias com falta de expectativas de melhora.

${ }^{66}$ Guía sobre el Estrés Ocupacional. Observatorio Permanente. Riegos Psicosociales, Madrid. Comisión Ejecutiva Confederal de UGT, Deciembre/2006, (p 15). Disponível em: 〈http://www.ugt.es〉. Acesso em 05.12.2009.
} 
Nesse mesmo sentido, lembramos que o assédio sexual, o assédio moral ou o assédio por razão de sexo, são diferentes do estresse laboral e do burnout. Esses últimos são patologias que tem mais relação com o próprio ambiente, com as condições de trabalho e com clientes e/ou usuários do que com colegas ou chefes. Já os diferentes tipos de assédio estão relacionados com uma intenção daninha, dirigida pela vontade de uma pessoa (ou de várias), causando mal estar e dano à vítima, considerados então, atos delitivos e violentos no ambiente de trabalho ${ }^{67}$.

Dados assustadores sobre os indicadores de morbidade e fatores de risco do Ministério da Saúde, mostram que a taxa de incidência de doenças relacionadas ao trabalho no Brasil no ano de 2007 foi de $7,17 \%$ e a taxa de mortalidade específica por acidente de trabalho foi de 9,17 por cada 10.000 trabalhadores $^{68}$.

Já o Ministério da Previdência social no Brasil avaliou os números de afastamento do trabalho e constatou que os transtornos mentais e comportamentais representaram mais de um terço dos casos entre os anos de 2000 e 2005, revelando que as áreas profissionais mais afetadas pelos transtornos de humor são o mercado financeiro, o refino de petróleo, o transporte ferroviário urbano e os bancos comerciais.

O Brasil apresenta um aumento significativo de casos de transtornos mentais de trabalhadores e esse tem sido um fator de preocupação que tem ocupado a

\footnotetext{
${ }^{67}$ Essa diferença ROJAS RIVERO esclarece muito bem em: Prevención de los Riesgos Psicossociales en el Ámbito de la Administración Pública". Tribuna Social. Revista de Seguridad Social y Laboral. Valencia, no 222, Junio de 2009, (p.12), afirmando: "así como el estrés laboral o el burn-out son patologías en sí mismas, esto es, enfermedades cuyos síntomas aparecen y denotan la existencia de un problema relacionado con el trabajo que puede derivar, como se ha dicho, de la propia persona del trabajador o del propio ambiente de trabajo; no ocurre lo mismo con el acoso, que también es un riesgo psicosocial, pero cuyos tintes son totalmente distintos en la medida en que un tercero, jefe, compañero, cliente, etc, interviene, con intención o no, hace daño, o provoca en el trabajador víctima de dicho comportamiento, un entorno hostil susceptible de generar en él determinadas alteraciones psicológicas." ${ }^{68} \mathrm{~A}$ incidência de doenças relacionadas ao trabalho e a taxa de mortalidade específica, segundo a pesquisa, correspondem a 100.000 trabalhadores com cobertura contra incapacidade laborativa decorrente de riscos ambientais do trabalho. As faixas etárias para o ano de 2007 são de 16-24 anos, 25-44 anos, 4559 anos e 60 anos e mais, suprimidos aqui, a idade ou sexo. Rede Interagencial de Informações para a Saúde. Ministério da Saúde. Disponível em: <http://www.datasus.gov.br/idb>. Acesso em 11.12.2009.
} 
agenda da área médica e do Instituto Nacional do Seguro Social (INSS) do Ministério da Previdência Social. A doença está na terceira posição do ranking das principais causas de pedidos de auxilio doença no INSS. Atividades desprestigiadas, perigosas ou mesmo tediosas, muitas vezes, estão relacionadas à incidência de transtornos mentais. Há um número alarmante também de casos de afastamentos do trabalho por depressão. No Brasil, não há uma legislação específica para estes casos, apesar do Anexo II do Decreto n 3.048, de 06 de maio de 1999 (já revogado), ter incluído a depressão como doença do trabalho. Mesmo assim, ela só é considerada como doença decorrente do meio ambiente laboral nos casos de exposição a algumas substâncias químicas tóxicas específicas. Em caso de dúvida quanto à sua origem, a ação é sempre em benefício ao trabalhador, amparando-o, conforme entendimento do artigo 21, I, da Lei $\mathrm{n}^{\circ} 8.213 / 91^{69}$. Uma vez caracterizada a depressão como doença ocupacional, é assegurado ao trabalhador o auxílio-doença acidentário, previsto no artigo 118 da mesma Lei, tendo a garantia de estabilidade me relação ao seu contrato de trabalho por 12 meses quando retornar. Porém, mesmo quando não reconhecido o nexo de causalidade entre a moléstia e o trabalho, uma vez constatada a depressão, o trabalhador é afastado da atividade laboral e passa a perceber o auxílio-doença (artigos 59 a 61). Fica ainda, a lacuna na legislação no que diz respeito ao assédio, já que a depressão pode ser uma das consequências de tal conduta.

Na Espanha, segundo a Unión General de los Trabajadores (UGT) em números gerais durante os nove primeiros meses do ano de 2009, foram declaradas 12.390 enfermidades profissionais. Nesse sentido, a UGT e o Observatório Permanente

\footnotetext{
${ }^{69} \mathrm{~A}$ lei $\mathrm{n}^{\circ}$ 8.213/91 dispõe sobre os Benefícios da Previdência Social, como o auxílio doença, salário maternidade, pensões, etc. Art. 21. Equiparam-se também ao acidente do trabalho, para efeitos desta Lei: I - O acidente ligado ao trabalho que, embora não tenha sido a causa única, haja contribuído diretamente para a morte do segurado, para redução ou perda da sua capacidade para o trabalho, ou produzido lesão que exija atenção médica para a sua recuperação.
} 
de Riesgos Psicossociales (OPRPS) realizaram uma pesquisa com uma amostra de 4.000 trabalhadores pertencentes aos setores têxtil, hoteleiro, de ensino, da saúde, telecomunicações, tele operadores, de carnes, de conservas vegetais, de azulejo, aéreo, do comércio e da segurança privada. Constataram que $75 \%$ dos trabalhadores entrevistados sofrem de estresse laboral, $81 \%$ sofrem da síndrome de burnout, $8 \%$ estão expostos a um ambiente de trabalho onde habitualmente ocorrem atos de violência verbal e/ou psicológica e $16 \%$ apresentam um elevado risco de padecer por assédio psicológico no trabalho ${ }^{70}$.

As enfermidades laborais, além de gerarem efeitos maléficos sobre a personalidade e a saúde do trabalhador, projetam seus efeitos na sociedade, pois geram desemprego, fazendo com que a vítima se torne um encargo para o Estado, uma vez que, o trabalhador passa a gozar de benefícios previdenciários temporários. Por isso, é inegável a importância e a necessidade de dispormos de uma cultura preventiva eficaz frente às enfermidades laborais que possam evitá-las.

\subsection{A Violência}

En las sociedades de nuestro mundo occidental altamente industrializado, el lugar de trabajo constituye el último campo de batalla en la cual una persona puede matar a otra sin ningún riesgo de llegar a ser procesada ante un tribunal.

Heinz Leymann

A violência revela-se como um fenômeno complexo, de forma que não se pode estabelecer um único conceito, por isso não temos a pretensão de esgotá-lo e nem

\footnotetext{
${ }^{70}$ UGT. Fundación para la Prevención de Riesgos Laborales. Boletín n ${ }^{\text {o }}$ 71/Agosto/Septiembre de 2009.
} Disponível em < http://extranet.ugt.org/saludlaboral/cec/Paginas/Default.aspx>. Acesso em 05.12.2009. 
tampouco dissertar sobre a violência urbana (criminalidade e delinquência). Nosso objetivo é ilustrar alguns conceitos e formas dessa conduta. Para tanto, afirmamos que a violência é um comportamento que causa dano a outra pessoa, negando a sua autonomia, a sua integridade física ou psicológica. É o uso excessivo da força, além do necessário ou esperado. O termo deriva do latim violentia (que por sua vez é amplo, sendo denominado qualquer comportamento ou conjunto de ações que deriva de vis, (força, vigor), ou seja, a aplicação da força com vigor contra qualquer coisa ou ente. Assim, a violência diferencia-se da força, palavras que costumam estar próximas na língua e pensamento cotidiano. Enquanto que força designa, em sua acepção filosófica a energia ou "firmeza" de algo, a violência caracteriza-se pela ação corrupta, impaciente e baseada na ira que não convence ou busca convencer o outro, simplesmente o agride.

Para o Dicionário Houaiss da Língua Portuguesa, a violência é a ação ou efeito de violentar, de empregar força física (contra alguém ou algo) ou de intimidação moral contra (alguém); ato violento, crueldade, força. No aspecto jurídico, o mesmo dicionário define o termo como o constrangimento físico ou moral exercido sobre alguém, para obrigá-lo a submeter-se à vontade de outrem: coação. Etimologicamente, violência é "la acción y efecto de violentar" ${ }^{71 "}$ e demonstra-se também, como um desequilíbrio de poder, a "acción que se realiza com brusquedad o fuerza excesivas com la finalidad de causar daño. Actitud del que abusa de la fuerza con esta finalidad ${ }^{72 \% .}$ Ela pode ser exercida de várias maneiras, umas concretas e visíveis, outras menos visíveis.

\footnotetext{
${ }^{71}$ Diccionario de la Real Academia Española. Disponível em: < http://www.rae.es/rae.html>. Acesso em 07/12/2009.

${ }^{72}$ Gran Diccionario de la Lengua Española. Idem nota anterior.
} 
Segundo a teoria de VAN SOEST ${ }^{73}$, a violência pode ser individual, institucional, estrutural e cultural. A individual é a mais fácil de identificar, e é considerada normalmente, como um delito. A violência institucional é invisível e indireta, sendo difícil de ser considerada como delito, manifestando-se no interior das instituições sociais, (escolas, prisões, delegacias, hospitais, etc.). Ela é promovida, desenvolvida e estimulada pelo próprio Estado, nega em nome das minorias privilegiadas, o acesso da população aos serviços públicos, abrangendo abusos cometidos em virtude das relações de poder desiguais entre profissionais e usuários dentro das instituições públicas. Já a violência estrutural e cultural se manifesta através de ações e práticas cotidianas como a discriminação de grupos pela sua raça, etnia, religião, orientação sexual, desigualdades econômicas, sexismo e racismo. RREITAS $^{74}$, afirma que "se puede añadir que la discriminación y la violencia estructural $e$ institucional, manifestada sobre todo a través de roles y del etiquetaje social y de los esteriotipos que condicionan hombres y mujeres, es el caldo de cultivo propicio para generar otros tipos de violencia: física, social, psicológica y moral, sexual, la llamada violencia doméstica o violencia de género, o violencia familiar y el acoso en el trabajo.”

Para a OMS a violência é a imposição de um grau significativo de dor e sofrimento evitáveis. Mas, os especialistas afirmam que o conceito é muito mais amplo e ambíguo do que essa mera constatação - de que a violência é a imposição de dor -, a agressão cometida por uma pessoa contra outra, mesmo porque, a dor é um conceito muito difícil de ser definido. Já para o Ministério da Saúde no Brasil, a violência é um

\footnotetext{
${ }^{73}$ SOEST, Van. The Global Crisis of Violence. Common problems, universal causes, shared solutions. Washington, D.C. National Association os Social Workers, 1997, (p.13).

${ }^{74}$ FREITAS, Lucia Barros. Discriminación Sexista y Otras Formas de Violencia Estructural e Institucional contra la Mujer. Madrid, 2004. Tese. Universidad Carlos III de Madrid. Instituto de Derechos Humanos Bartolomé de las Casas, (p.381).
} 
evento representado por ações realizadas por indivíduos, grupos, classes ou nações que ocasionam danos físicos, emocionais, morais, espirituais a si próprios ou aos outros, como, por exemplo, a agressão física, o abuso sexual, a violência psicóloga e a violência institucional.

Muitos apontamentos crêem que a violência nas relações de trabalho se deve a industrialização e o crescimento urbano desordenado, mas, os fatores sociais, econômicos e culturais também interferem no comportamento das pessoas, resultando conflitos violentos. A violência nas relações de trabalho fere os diretos fundamentais da pessoa e atenta contra sua dignidade, em especial o direito ao trabalho, à igualdade, à integridade, à saúde física e psíquica. Inclui também as ameaças, a discriminação, a intimidação, o abuso, a perseguição que induz ao medo, a exclusão e a indiferença no meio laboral. Nesse escopo, a violência psicológica é o emprego intencional do poder, ação ou omissão capaz de resultar em malefício ao desenvolvimento físico, mental, espiritual, moral e sexual, abrangendo desde a agressão verbal, atitudes discriminatórias, o assédio moral e até o sexual ${ }^{75}$.

Portanto, entendemos que a violência não se resume necessariamente na força física que constitui uma agressão à dignidade humana. O conceito de violência está atrelado também à violência moral ou psicológica que são tão devastadoras como a violência física. É disso que vamos tratar aqui: a violência na sua forma mais sutil e que pode desencadear os vários tipos de assédio - o assédio moral, sexual e o assédio por razão de sexo e a necessidade da implementação de ações preventivas no ambiente de trabalho capazes de inibir essas condutas. Na continuação, apresentamos com mais detalhes essas condutas que podem ocorrer no ambiente laboral e que violam os direitos

\footnotetext{
${ }^{75}$ ALKIMIN. Maria Aparecida. Violência na Relação de Trabalho... Op. Cit. Nota 33, (p.111).
} 
humanos do trabalhador ou trabalhadora. Vamos destacar com mais detalhes, o assédio moral, não por ser o mais importante, mas, por ser o mais comum nas relações empregado/empregador.

\subsubsection{O Assédio Moral}

Por certo, existem várias denominações para o assédio moral. Na França, por exemplo, o fenômeno é conhecido como harcélement moral, na Itália, a denominação adotada é mobbing, em Portugal, é terrorismo psicológico ou assédio moral, e na Espanha acoso moral ou mobbing. E na Inglaterra, recebe o nome de bullyng. Esses termos indicam condutas agressivas, como a discriminação e o assédio moral e sexual. Nos Estados Unidos, o assédio moral é conhecido como harassment, significando ataques constantes de agressividade. Mesmo faltando uma legislação específica sobre a conduta de assédio no ambiente laboral, existem muitas pesquisas a respeito no Brasil e na Espanha, porém, o termo tem sido muitas vezes utilizado de maneira errônea e confusa. Discorreremos sobre o tema utilizando idéias e teorias de autores que pesquisaram a fundo o tema e com rigor científico.

\section{Conceitos e Características}

No Brasil não há uma denominação específica para o assédio moral. Segundo a pesquisa realizada por $\operatorname{SILVA}^{76}$, encontramos as seguintes denominações para essa conduta: humilhação no trabalho, violência moral, assédio psicológico, violência psicológica, terror ou terrorismo psicológico no trabalho, perversão moral ou abuso moral. Entretanto, iremos trabalhar aqui, com a expressão assédio moral. A

\footnotetext{
${ }^{76}$ SILVA. Jaqueline Heldt. Assédio Moral nas Relações de Trabalho Frente ao Princípio da Dignidade da Pessoa Humana. Porto Alegre (RS). Trabalho de conclusão de curso apresentado a Pontifícia Universidade Católica do Rio Grande do Sul, 2006, (p.32).
} 
palavra assédio provém do latim obsisiu, obsidere, que significa por-se diante, sitiar, $\operatorname{atacar}^{77}$. Moral, por sua vez, significa o conjunto de regras de condutas consideradas como válidas, onde se apresenta como um guia de como deveríamos agir e viver. Para $\mathrm{KANT}^{78}$ as leis morais devem ser aplicadas a todo ser racional como tal, ele a considerava universal: um conjunto de regras que é o mesmo para todos, deve ser possível para todos agir sempre moralmente (ainda que seja muito improvável que o façam). Dizia ainda "age de tal modo que sempre trates a humanidade, seja na tua própria pessoa ou na de qualquer outro, nunca simplesmente como um meio, mas sempre como também um fim". Vale ressaltar, que a contingência histórica e a particularidade dos direitos humanos é perfeitamente compatível com a concepção de direitos humanos como direitos morais universais, portanto, o assédio moral fere os direitos humanos do trabalhador.

Na década de 1980, uma equipe de investigação sueca coordenada pelo psiquiatra alemão LEYMANN, recorreu ao conceito de mobbing para referir-se a procedimentos muito conflitivos no local de trabalho. Após a investigação, o termo foi popularizado no mundo laboral ${ }^{79}$. A Nota Técnica $n^{\circ} 476$ de 1988 do Instituto Nacional

\footnotetext{
${ }^{77}$ FERREIRA, Aurélio Buarque de Holanda. Novo Aurélio. Século XXI. O Dicionário da Língua Portuguesa. $3^{\text {a }}$ edição, Rio de Janeiro: Editora Nova Fronteira, 1999. Para o dicionário: assédio: cerco posto a um reduto para tomá-lo, sítio: Na Holanda, quando ao levantar-se o cerco de Leide pelo Duque de Alba, o povo se reúne no templo para entoar o coral de Lutero, a grande multidão, dilacerada pelas resistências do assédio e pelas devastações da fome, esquece-se da sua própria dor (Ramalho Ortigão. Figuras e questões Literárias, I, (pp.128-129). Insistência importunas junto de alguém, com perguntas, propostas, pretensões, etc. "Foi, aí, ainda no limiar da adolescência que começou a sofrer o assédio dos seres do outro sexo que a perseguiam com olhares e propostas". (Amando Fontes. Rua do Siriri, p.48).

${ }^{78} \mathrm{E}$ sobre as máximas morais de KANT ele afirmava que: "Trata-se do que é possível escolher, não do que gostaríamos de escolher. Escolher comportar-se de uma maneira que é possível que todos adotem é, ao mesmo tempo, imoral e irracional, e deveria ser rejeitado". O autor STEPEHN LAW, dissertando sobre Immanuel Kant e a fundação da moral na razão em sua obra: Filosofia. Rio de Janeiro: Zahar, 2008, (p.105).

${ }^{79}$ Em 1982, LEYMANN y GUSTAVSON publicam um estudo intitulado Psychological violence at workplace: two exploratives studies, onde constataram que distintos sujeitos exercem na empresa uma violência psicológica extrema, de forma sistemática e corrente, ao menos uma vez por semana - durante um tempo prolongado - mais de seis meses, sobre um trabalhador, com o objetivo de destruir a comunicação do trabalhador com a empresa, perturbando o exercício de suas funções, e como consequência disso o abandono de suas funções, desencadeando vários tipos de doenças.
} 
de Seguridad e Higiene en el Trabajo da Espanha ${ }^{80}$ define o assédio moral como a "situación en la que una persona o un grupo de personas ejercen una violencia psicológica extrema (en una o más de las 45 formas o comportamientos descritos por el “Leymann Inventory of Psychological Terrorization”), de forma sistemática al menos una vez por semana durante un tiempo prolongado (más de 6 meses) sobre otra persona en el lugar de trabajo."

É importante salientar, que, em regra geral, a vítima só percebe que está sendo assediada moralmente na última fase do conflito, ou seja, quando a ação de assédio já lhe causou danos. Sendo assim, do ponto de vista temporal, acreditamos que o importante é atentar ao tipo de comportamento que o assediador tem em relação à vítima, o tempo em que ocorre tal conduta é menos importante.

Outros pesquisadores tem ajudado na investigação e no estudo desse fenômeno no mundo do trabalho, como a psiquiatra HIRIGOYEN ${ }^{81}$. Na Espanha, destaca-se o trabalho de PIÑUEL y ZABALA ${ }^{82}$, ao difundirem o barómetro cisneros sobre o assunto, revelando dados e constatando que o assédio moral tem o objetivo de reduzir, intimidar e consumir emocionalmente a vítima. Os autores dizem que,

con el objetivo de intimidar, apocar, reducir, aplanar, amedrentar y consumir emocional e intelectualmente a la víctima, con vistas a eliminarla de la organización o a satisfacer la necesidad insaciable de agredir, controlar y destruir que suele presentar el hostigado, que aprovecha la situación que le brinda la situación organizativa particular (reorganización, reducción de costes, burocratización,

\footnotetext{
${ }^{80}$ Informação disponível em:<http://www.insht.es/portal/site/Insht/>. Acesso em 08.12.2009.

${ }^{81}$ HIRIGOYEN, Marie France. El acoso moral (1998); El acoso moral en la vida cotidiana. Barcelona: Paidós, (1999).

${ }^{82}$ IÑAKI PIÑUEL realizou um importante estudo denominado Barómetro cisneros (questionário individual sobre psicoterror, negação, estigmação nas organizações socias) Universidade de Alcalá de Henares, com o objetivo de saber dos índices e o estado de violência no ambiente de trabalho das empresas. O questionário foi aplicado pela $1^{\text {a }}$ vez em 2001 com uma amostra de 1000 trabalhadores. A pesquisa revelou que $16 \%$ dos trabalhadores na Espanha sofriam de assédio moral no trabalho.
} 
cambios vertiginosos, etc.) para canalizar una serie de impulsos y tendencias psicopáticas ${ }^{83}$.

Nesse sentido, assédio moral é a exposição dos trabalhadores e trabalhadoras à situações humilhantes e constrangedoras, repetitivas e prolongadas durante a jornada de trabalho ou no exercício de suas funções laborais. $\mathrm{O}$ assédio moral é mais comum em relações hierárquicas autoritárias onde predomina a relação antiética de chefes com seus subordinados, desestabilizando a vítima no ambiente de trabalho. Nesse sentido, ROJAS RIVERO ${ }^{84}$, também revela que, "el acoso moral se configura como una situación de violencia psíquica o intimidación que, ejercida de forma reiterada, pretende conseguir el abandono del trabajador atentando a su dignidad a través de conductas humillantes y vejatorias; e que puede ser realizada tanto por un superior o el mismo empresario como por otros trabajadores que, habitualmente, propician la situación de aislamiento del acosado." A vítima é isolada do grupo, passando a ser hostilizada, inferiorizada e, muitas vezes, até ridicularizada diante dos seus pares. O assédio moral não é um ato isolado, porque pressupõe a repetição sistemática da intenção do agressor.

No ordenamento jurídico brasileiro, não existe uma denominação específica para o assédio moral, porém, o importante conceito de HIRIGOYEN pode ser considerado o pontapé inicial para um estudo mais profundo do fenômeno. Ela conceitua o assédio moral, dizendo que constitui qualquer conduta abusiva que se manifesta por comportamentos, palavras, atos, gestos, escritos trazendo dano à personalidade, à dignidade ou à integridade física ou psíquica de uma pessoa ou

\footnotetext{
${ }^{83}$ PIÑUEL y ZABALA, I. Mobbing: Cómo sobrevivir al acoso psicológico en el trabajo. Santander: Sal Terrae, 2001, (p.55).

${ }^{84}$ ROJAS RIVERO, Gloria P. Delimitación, prevención y tutela del acoso laboral. Albacete: Editorial Bomarzo, 2005, (p.62).
} 
colocando em perigo seu emprego ${ }^{85}$. Acrescenta-se que, o assédio moral se manifesta como a violência psíquica praticada no local de trabalho que consiste em atos, gestos, palavras e comportamentos vexatórios, humilhantes, degradantes e constrangedores, ocorrendo de forma sistemática e prolongada e com clara intenção discriminatória e perseguidora visando eliminar a vítima da organização do trabalho ${ }^{86}$. Nesse mesmo sentido, GUEDES ${ }^{87}$ define o assédio moral ou mobbing, como, “(...) todos os atos comissivos ou omissivos, atitudes, gestos e comportamentos, do patrão, da direção da empresa, de gerente, chefe, superior hierárquico ou de colegas, que traduzem uma atitude de contínua e ostensiva perseguição que possa acarretar danos relevantes às condições físicas, psíquicas, morais e existenciais da vítima”.

Essa conduta de assediar, geralmente, provém da inveja, dos ciúmes, da competitividade, da rivalidade, e para que o agressor se satisfaça, ele então ignora, humilha e destrói aos poucos a auto estima da sua vítima, tornando a conduta mais prazerosa ainda, se houver platéia, citam-se - colegas de trabalho e meros expectadores - que, num ato covarde fazem total silêncio, contribuindo para o sucesso do agressor.

Uma das características do assédio moral é a humilhação que a vítima sofre. Mas, o que é sentir-se humilhado neste contexto? BARRETO ${ }^{88}$ afirma que humilhação é o sentimento de ser ofendido, menosprezado, rebaixado, inferiorizado, submetido, vexado e ultrajado pelo outro, e mais ainda, é sentir-se um ninguém, sem valor, inútil, magoado, revoltado, perturbado, modificado, indignado, com raiva. $\mathrm{E}$

\footnotetext{
${ }^{85}$ HIRIGOYEN, Marie-France. Assédio Moral: a violência perversa no cotidiano. Rio de janeiro, Bertrand Brasil, (p.17). Apud: ALKIMIN. Maria Aparecida. Assédio Moral na Relação de Emprego. Curitiba: Juruá, 2006, (p.36).

${ }^{86}$ ALKIMIN. Maria Aparecida. Assédio Moral na Relação de Emprego. Curitiba: Juruá, 2006, (p.36).

${ }^{87}$ GUEDES, Márcia Novaes. Terror Psicológico no Trabalho. $2^{\mathrm{a}}$ edição. São Paulo: LTR, 2004, (p.32).

${ }^{88}$ BARRETO, Margarida. Violência, Saúde e Trabalho (uma jornada de humilhações), $2^{\mathrm{a}}$ reimpressão, São Paulo: Editora PUCSP, 2006, (p.188).
} 
porque é perverso? Porque o assédio é realizado de maneira intencional, planejada para "queimar" ou "colocar pra fora" a vítima.

Do exposto, é necessário frisar que o assédio moral constitui um fenômeno social difícil de provar ou de caracterizar. As condutas que tipificam o assédio moral no ambiente de trabalho são: o abuso de autoridade (ditar ordens impossíveis para o trabalhador, deixá-lo sem ocupação e incomunicável sem uma causa que justifique, exigir tarefas inúteis e que não tenham valor produtivo, fazer represálias com aqueles que denunciam ou demandem contra a empresa), dispender tratamento vexatório (insultar ou menosprezar a vítima de forma repetida diante dos outros, fazer intrigas falsas a respeito da vida e do trabalho da vítima), o assédio discriminatório (por crenças religiosas, sexo ou orientação sexual, por idade, estado civil, origem, etnia, nacionalidade ou deficiência). Outras condutas ou comportamentos no ambiente de trabalho que não tipificam o assédio moral são: modificações de postos ou métodos de trabalho sem seguir os procedimentos legalmente estabelecidos, pressões para aumentar a jornada de trabalho ou realizar determinadas tarefas, exigir metas de venda ou de resultados, conflitos durante greve ou protestos, ofensas esporádicas e pontuais realizadas por várias pessoas sem coordenação entre elas, repreensões sem desqualificar por não realizar bem um determinado trabalho ou ainda, avaliações periódicas sobre o desempenho das funções. Portanto, é possível afirmar que o assédio configura-se:

a) Na repetição sistemática, (perseguição e humilhações repetidas);

b) $\mathrm{Na}$ intencionalidade (ter essa conduta de modo pensado, premeditado);

c) Na direcionalidade (uma pessoa do grupo é escolhida como bode expiatório); 
d) Na temporalidade (durante a jornada de trabalho) e na degradação deliberada das condições de trabalho.

\section{A Discussão Teórica no Brasil}

O fenômeno da conduta de assédio moral não é atual, porém, no Brasil a discussão e a preocupação com o tema é recente. Cabe lembrar, que no ordenamento jurídico brasileiro não há uma lei específica que trate do assédio no ambiente de trabalho em suas mais variadas manifestações. Porém, o Tribunal Superior do Trabalho (TST) já vem reconhecendo o problema em diversas decisões, onde as vítimas de assédio exigem reparação pelos danos causados pelas empresas. Até a presente data, tramita no plenário da Câmara dos Deputados Federais um Projeto de Lei Federal ${ }^{89}$, o PL 4742/2001 que pretende incluir o artigo 146-A do Código Penal brasileiro, com a seguinte redação sobre o assédio moral:

Depreciar, de qualquer forma e reiteradamente a imagem ou o desempenho do servidor público ou empregado, em razão de subordinação hierárquica funcional ou laboral, sem justa causa, ou tratá-lo com rigor excessivo, colocando em risco ou afetando sua saúde física ou psíquica. Pena: detenção de um a dois anos.

$\mathrm{O}$ artigo aborda a questão do constrangimento ou da ameaça de uma forma bastante genérica, causando certa insegurança jurídica para a própria vítima, não especificando a sua intencionalidade. Quando expressa que "em razão de subordinação hierárquica funcional ou laboral", entende-se, que o assédio ocorre somente de maneira

\footnotetext{
${ }^{89}$ No Brasil, um projeto de lei pode ter sua tramitação iniciada tanto na Câmara dos Deputados como no Senado Federal, devendo ser avaliado e aprovado por ambas as casas legislativas. O Presidente da República pode vetar projetos de lei parcial ou totalmente.Todo projeto de lei recebe um número específico, ou protocolo, que lhe é designado a fim de facilitar a sua identificação e acompanhamento.O web site da Câmara dos Deputados permite que sejam realizadas pesquisas rápidas via Internet para verificar em que estágio se encontram os projetos de lei, posição e andamento dos projetos. Disponível em: 〈http://www2.camara.gov.br/proposicoes>. Acesso em 20.03.2009.
} 
descendente, o que não é verdade. Mais adiante, nos dedicaremos a detalhar as outras formas existentes da conduta e os tipos, facilitando assim, a compreensão e quiçá a futura tipificação desse delito.

Além da Carta Magna brasileira existem leis infraconstitucionais que são utilizadas parta proteger à dignidade da pessoa. Algumas cidades brasileiras adotaram leis municipais e vários Projetos de Lei tramitam nas Assembléias Legislativas dos Estados. Em regra, essas leis, utilizam o mesmo conceito de assédio moral. Elas consideram o assédio moral todo tipo de ação, gesto ou palavra que atinja, pela repetição, a auto-estima e a segurança do indivíduo, fazendo-o duvidar de si e da sua competência, implicando em dano no ambiente de trabalho, na evolução da carreira profissional ou na estabilidade do vínculo empregatício do funcionário. Essas ações são definidas na lei, como marcar tarefas com prazos impossíveis, passar alguém de uma área de responsabilidade para funções triviais, tomar créditos de idéias de outros, ignorar ou excluir um funcionário, só se dirigindo a ele através de terceiros, sonegar informações de forma insistente, espalhar rumores maliciosos, criticar com persistência e subestimar esforços.

No Brasil também existem várias demandas trabalhistas por assédio moral no ambiente de trabalho. Porém, as vítimas tem dificuldade de provar tal conduta, pois, ela é camuflada e se dá às escuras. Por outro lado, também é difícil justificar a violação por dano moral, porque a simples sensação de sofrimento da vítima não caracteriza o dano moral. Nesse sentido, a maioria das ações trabalhistas com pedido de indenização por dano moral (sob a alegação de assédio moral), são julgadas improcedentes por completa ausência de provas. Isso ocorre porque, o empregado não consegue provar o ato lesivo à sua integridade psíquica, segundo a regra clássica do 
ônus da prova prevista no artigo 33 do Código de Processo Civil (CPC) ${ }^{90}$, onde prevê que a conduta de assédio moral é um fato que compete ao empregado provar, independentemente das dificuldades que possa ter em demonstrar os fatos.

Apesar disso, há pesquisas acadêmicas e campanhas de mobilização e conscientização sobre o tema, dentre elas destacamos a dissertação de mestrado defendida no ano de 2000 na Pontifícia Universidade Católica de São Paulo (PUC), denominada: "Uma jornada de humilhações" (BARRETO, 2000). A autora realizou uma pesquisa entre março de 1996 e julho de 1998, entrevistando 2.072 trabalhadores, com a ajuda do sindicato dos trabalhadores nas indústrias químicas, plásticas, farmacêuticas e similares de São Paulo. Na amostra pesquisada, 42\% (494 mulheres e 761 homens) disseram que foram vítimas de humilhações, situações vexatórias e repetitivas no ambiente de trabalho. Ela apontou o medo como um sentimento comum entre os pesquisados, expressando que,

O homem prefere a morte à perda da dignidade, se percebe muito bem como saúde, trabalho, emoções, ética, e significado social se configuram num mesmo ato, revelando a patogenicidade da humilhação ${ }^{91}$.

Vale desatacar, a campanha intensa da categoria bancária no país, pois, se trata de um trabalho onde se destacam os funcionários que vendem mais os produtos e serviços das instituições bancárias. A competitividade entre os funcionários e os próprios bancos, desencadeia vários tipos de assédio. Podemos citar o abuso do poder,

\footnotetext{
${ }^{90}$ CÓDIGO DE PROCESSO CIVIL BRASILEIRO (Lei no 5.869/73). CPC. Artigo 333: O ônus da prova incumbe: I - ao autor, quanto ao fato constitutivo do seu direito; II - ao réu, quanto à existência de fato impeditivo, modificativo ou extintivo do direito do autor. Parágrafo único. É nula a convenção que distribui de maneira diversa o ônus da prova quando: I - recair sobre direito indisponível da parte; II tornar excessivamente difícil a uma parte o exercício do direito. Lei disponível em <http://www.planalto.gov.br/CCIVIL/Leis/L5869.htm>. Acesso em 30.11.2009.

${ }^{91}$ BARRETO. Margarida Maria Silveira. Uma Jornada e humilhações. 266 pp. Dissertação. Mestrado em Psicologia Social. PUC, São Paulo, 2000.
} 
as metas abusivas e a crescente terceirização dos serviços bancários, onde os bancos públicos e as agências privada tem, cada vez menos funcionários diretos e, cada vez mais demanda, gerando um estresse organizacional intenso. O Projeto denominado “Assédio moral na categoria bancária: uma experiência no Brasil”, que se propõe a traçar uma radiografia do assédio no ambiente de trabalho, do nível de humilhação e de constrangimento a que os bancários são vítimas no cotidiano. Tal projeto é realizado pelo Sindicato dos Bancários de Pernambuco ${ }^{92}$, que produziu também, uma cartilha informativa muito interessante denominada de: “Assédio Moral: é ilegal e imoral, você não pode ser cúmplice, denuncie."

A cartilha ${ }^{93}$ tem como objetivo informar e formar agentes multiplicadores para possibilitar o aprofundamento do debate em torno do assédio moral. Ela traz definições, conceitos, formas de assédio e orientações sobre como a vítima pode denunciar esse abuso. E, quando se fala em denunciar, as palavras de FREITAS $^{94}$ nos alertam para essa prática cruel nas empresas, incentivando a denúncia. Ela diz que o silêncio fala, e as pessoas esquecem que as palavras, mesmo as não-ditas, são armas que podem ser letais: é triste, muito triste, reconhecer que uma vida vale tão pouco.

Fica registrada a necessidade de se aprovar uma legislação federal específica sobre o assédio moral laboral no Brasil. Entretanto, a questão deve ser abordada de maneira multifacetária, verificando, além do ambiente laboral, as características pessoais dos empregadores e trabalhadores que influenciam nas suas

\footnotetext{
${ }^{92}$ Informações obtidas do Sindicato dos Bancários de Pernambuco. Disponível em:<http://www.bancariospe.org.br/>. Acesso em 20.03.2009.

${ }^{93}$ Cartilha: "Assédio Moral: é ilegal e imoral, você não pode ser cúmplice, denuncie”. Ver mais em $<$ http://www.bancariospe.org.br/assedio/cartilha.htm>. Acesso em 20.03.2009. Segundo um dos diretores executivos do sindicato dos Bancários de Pernambuco, a cartilha já foi utilizada com inúmeras adaptações por outros sindicatos e ramos distintos. Ele acrescenta que hoje o trabalho sobre assédio moral, é capaz de dialogar com outras formas de violência social, moral e institucional, como o Machismo, Racismo e Homofobias.

${ }^{94}$ FREITAS, Maria Ester de. Assédio Moral e Assédio Sexual: faces do poder perverso nas organizações. Revista Administração de Empresas, volume 41, nº 02 (pp.8-19), abril/junho de 2001.
} 
relações profissionais. Cabe às empresas, à sociedade e ao Estado, agirem para que essa violência tão comum cesse. Não se pode aceitar o assédio moral como algo rotineiro nas relações de trabalho.

\section{Os Tipos de Assédio}

$\mathrm{O}$ interesse pelo estudo fez com que a doutrina identificasse comportamentos diferentes de assédio moral, dependendo da forma como se manifesta. Assim, é possível falar em assédio descendente, assédio ascendente e assédio horizontal. Podemos afirmar que, o assédio moral não ocorre somente de cima para baixo, ou seja, não provém apenas de superiores e chefes. $\mathrm{O}$ fenômeno também acontece entre colegas de trabalho e seus pares, o denominado assédio horizontal, quando um ou mais trabalhadores são assediados por outros companheiros de trabalho que ocupam postos similares ou pertencem ao mesmo nível hierárquico, ocorrendo assim, o assédio entre iguais. Geralmente ele acontece por causa da disputa por postos de trabalho e promoção. Além disso, a monotonia e a repetição de tarefas traz, segundo a medicina especializada no trabalho, perturbações psicossomáticas, e, neste caso, os agressores escolhem alguém como vítima porque não tem nada mais interessante para fazer!

O assédio descendente (bossing), do inglês boss, que significa chefe ou empregador, ocorre quando um indivíduo tem uma certa relação de poder dentro da empresa e assedia um ou vários trabalhadores que estão subordinados a ele. Para HIRIGOYEN, esse é o tipo de assédio mais frequente no contexto atual, onde os trabalhadores assalariados estão preparados para aceitar qualquer coisa na tentativa de conservarem seus empregos. A empresa permite que um indivíduo dirija seus subordinados de um modo tirânico ou perverso, por conveniência ou porque lhe parece 
importante. Mas, as consequências para o subordinados são muito graves ${ }^{95}$. Sem dúvida, é a forma de assédio em que as consequências para a saúde da vítima são mais graves porque ela tem mais dificuldade em resolver o problema, já que o conflito é com seu próprio chefe.

O ascendente, por sua vez, é menos frequente e mais difícil de ser identificado. Ele ocorre quando o assediado é uma pessoa que ocupa um cargo maior dentro da empresa, que é atacado por um ou vários de seus subordinados. Geralmente nestes casos, os subordinados agridem seu superior hierárquico porque eles se opõem a indicação deste responsável, como por exemplo, na substituição de uma chefia. O chefe é atacado geralmente em razão do seu autoritarismo, da sua arrogância ou da sua parcialidade. $\mathrm{O}$ assediado cria, certa resistência em comunicar a conduta ao empregador para não demonstrar fraqueza, perder sua credibilidade ou sua atual posição.

Analisando de uma forma breve esses exemplos, podemos afirmar que o assédio do tipo ascendente é menos frequente porque a relação de poder e hierarquia nas organizações é muito presente e, às vezes, constitui-se em abuso de poder, podendo gerar outros tipos de crime como a agressão verbal caracterizada sobre a forma de calúnia, injuria ou difamação ${ }^{96}$ e ainda agressões físicas ocasionando lesões corporais leve, grave ou gravíssima.

\section{O Assediador e o Assediado}

\footnotetext{
${ }^{95}$ HIRIGOYEN. Marie-France. El acoso moral. El maltrato psicológico en la vida cotidiana. Barcelona: Paidós, 1999, (p.55).

${ }^{96}$ Segundo o CÓDIGO PENAL BRASILEIRO. Decreto-Lei no 2.848/1940. São crimes contra a honra e significam: Calúnia (artigo 138): mentira, falsidade, invenção. Difamação (artigo139): calunia, descrédito. Injúria (artigo 140): injustiça, afronta, dano, lesão.
} 
As figuras do empregado e do empregador não possuem posições definidas de assediado (vítima) e assediador (agressor) em relação ao assédio moral, porque as posições podem ser alteradas como vimos anteriormente. Assim, no caso do assédio descendente normalmente o agressor é o superior hierárquico, no assédio ascendente os subordinados e no assédio horizontal os próprios colegas.

As características que definem o assediador são a exagerada centralização em si mesmo, a falta de empatia e interesse pelos outros, a necessidade de se auto afirmar e de ser aprovado pelo grupo. Sobretudo, são os chefes ou os superiores hierárquicos medíocres profissionalmente e com baixa auto estima que assediam de forma mais freqüentemente. De acordo com PIÑUEL y ZABALA ${ }^{97}$, os assediadores são: "personas que tienen una profunda alteración de la personalidad. Son sujetos que carecen de norma moral interna; que no dudan a eliminar un posible competidor (...) individuo narcisista, con un profundo complejo de inferioridad, pero que ante de los demás siempre está diciendo lo mucho que vale y los buenos que son sus trabajos (...) tienden a rodearse de personas mediocres o sumisas que confirmen esta idea grandiosa que tienen de si mismos".

As condutas do assediador são geralmente cruéis, podendo se manifestar em atitudes como as de privar o assediado de comunicar-se ou falar de suas opiniões a respeito do trabalho, impedindo-o de agir, pensar ou reagir, proibindo-o de se comunicar com os outros, deixando-o ocioso e não passando-lhe nenhuma tarefa rotineira. Dessa maneira, busca desqualificar a vítima, humilhando-a no ambiente de

\footnotetext{
${ }^{97}$ PIÑUEL y ZABALA Apud: ESCUDERO MORATALLA, José Francisco y POYATOS i MATAS, Glória. Mobbing: Análisis Multidisciplinar y estrategia legal. Barcelona: Bosch, 2004, (p.110).
} 
trabalho, visando desmoralizá-la, tornando o ambiente hostil e pesado, podendo, em alguns casos forçá-la a pedir demissão. Nesse sentido HIRIGOYEN ${ }^{98}$, afirma que,

Utilizam-se insinuações desdenhosas para desqualificá-la. Fazem gestos de desprezo diante dela (suspiros, olhares desdenhosos, levantar de ombros...) e desacredita diante de colegas, superiores e subordinados, rumores são espalhados a seu respeito, problemas psicológicos são atribuídos a pessoa, zombaria de deficiências físicas ou de seu aspecto, críticas de sua vida privada, zombaria de origem ou nacionalidade, implicância com religião ou convicção política, tarefas humilhantes são atribuídas e injúrias com termos obscenos e degradantes.

Já no caso do assediado (vítima) há uma série de fatores que a levam a ser mais propensa a sofrer o assédio no ambiente de trabalho. Elas são geralmente pessoas que despertam algum tipo de inveja no trabalho por serem bons profissionais, dedicados e atraentes fisicamente ou inseguros, que parecem ser mais vulneráveis devido a alguma debilidade ou demonstram necessitar de maior proteção. É possível também, que sejam pessoas ativas que trabalham muito, tem idéias inovadoras ou criativas e que, de alguma forma, se sobressaem representando um perigo profissional para $\mathrm{o}$ assediador.

Alguns autores ainda afirmam que, as pessoas com mais riscos de sofrerem assédio no trabalho são aquelas que possuem personalidade forte. Os casos que chegam aos Tribunais, normalmente, são daquelas pessoas que sofrem o assédio devastador e que tem um papel relevante dentro da empresa por serem líderes ou possuírem um elevado conceito no trabalho e auto-estima. Entretanto, é importante

\footnotetext{
${ }^{98}$ HIRIGOYEN. Marie-France. Mal-Estar no trabalho: redefinindo o assédio moral. $3^{\text {a }}$ edição, Rio de Janeiro: Beltrand, 2006, (p.66).
} 
salientar que, não se pode estabelecer um único perfil para o assediado, pois, qualquer pessoa está suscetível a se converter em uma vítima de assédio moral no trabalho.

\subsubsection{O Assédio Sexual}

Enquanto o homem e a mulher não se reconhecerem como semelhantes, enquanto não se respeitarem como pessoas em que, do ponto de vista social, político e econômico, não há a menor diferença, os seres humanos estarão condenados a não verem o que têm de melhor: a sua liberdade.

Simone de Beavouir

O assédio sexual, embora não seja um assunto inédito na organização do trabalho nos últimos tempos, ganhou maior notoriedade em razão de caracterizar uma forma de violência praticada na relação de trabalho, que denigre a personalidade e dignidade da pessoa humana. Sem dúvida, o assédio sexual no trabalho, se trata de um fenômeno atual da problemática laboral. Não é assédio no sentido estrito, porque o assédio sexual tem uma finalidade distinta: que é de obter relações sexuais com a vítima, caracterizando uma conduta que constitui discriminação, abuso do poder, e sobretudo, uma violação dos direitos humanos. GONZÁLEZ DE RIVERA ${ }^{99}$, assim define o assédio sexual:

El acoso sexual es una forma de abuso que incluye el hostigamiento reiterado y continuado de una persona con fines, métodos $\mathrm{o}$ motivaciones de naturaleza sexual, ejercido desde una posición de poder, físico, mental o jerárquico, generalmente en un contexto laboral, docente, domestico o de cualquier otra índole que implique subordinación del acosado o acosada.

${ }^{99}$ GONZÁLEZ DE RIVERA, José Luis. El maltrato psicológico. Como defenderse del mobbing y otras formas de acoso. Madrid: Practico Espasa, 2002, (p.121). 
Nesse sentido, vale salientar que, o assédio sexual não está ligado necessariamente ao ambiente onde acontece o fato, mas sim, a relação de poder que envolve as pessoas, onde o assediador cerca a vítima deixando-a sem saída, perseguindo-a e penalizando-a. Do ponto de vista de QUINTANA PELLICER ${ }^{100}$,

Este problema no se origina sólo por una cuestión de apetencias sexuales, aunque estas evidentemente están en su origen, sino que también aparece ligado a circunstancias tales como la existencia en las relaciones de trabajo de conductas hostiles, discriminatorias o despectivas, preferentemente hacia el género femenino, que crean un entorno que lo hace posible y a situaciones de desequilibrio de poder a favor del acosador frente al acosado.

Dentro disso, é importante salientar que, o assédio sexual no trabalho, pressupõe uma relação de poder entre o assediante e o assediado, mas, não é o requisito essencial, pois, o assédio pode ocorrer também entre colegas de trabalho, entre empregado e cliente e empregado e empregador. Considerando que, na maioria dos casos noticiados, o sujeito ativo da conduta do assédio sexual é o homem, e que são as mulheres as vítimas mais comuns, embora possa acontecer ao contrário, não se descarta a possibilidade da configuração de assédio, entre pessoas do mesmo sexo.

No entanto, existem certos comportamentos denominados de "grosserias", "indelicadezas" ou "galanteios" no trato com as outras pessoas. Mas não é isso que caracteriza o assédio sexual, porque ele é um comportamento que parte de uma perseguição continua com o intuito de constranger, intimidar e ofender moralmente alguém, ato que deve ser considerado ilícito. Desse modo, conceituamos o assédio sexual como uma perseguição de natureza sexual não desejada, causando mal estar na

\footnotetext{
${ }^{100}$ QUINTANA PELLICER, José. El acoso sexual en el trabajo en la doctrina del Tribunal Constitucional y de los Tribunales del Orden Social de la Jurisdicción. Tribuna Social. Revista de Seguridad Social y Laboral. Valencia, nº 222, (101p), Junio de 2009, (p.40).
} 
vítima e constrangimento, podendo levar a se manifestarem também, doenças de ordem psíquica e emocional.

Nesse sentido, PAMPLONA FILHO ${ }^{101}$, diz que o assédio sexual, enquanto ilícito, deve ser considerado como uma violação ao postulado dogmático da liberdade sexual, não devendo ser encarado como uma reles "infração moral", até mesmo porque, no âmbito das relações sociais, os limites da juridicidade e da moralidade são muito tênues.

De acordo com LASSO $^{102}$ o assédio sexual teria dois significados diferentes no âmbito laboral: um é o que corresponde ao abuso do poder que se baseia em uma situação do predomínio masculino coletivo, isto é, quando os homens ocupam todos os postos de direção ou individualmente, quando o agressor se aproveita da sua condição de chefe para assediar. O segundo significado, é de que os homens constatam que sua perda de poder implica na impugnação de maior igualdade existentes por meios sexuais.

Há diferentes tipos de assédio sexual, dependendo da maneira como o assediador conduz a vítima. Segundo uma pesquisa realizada em 1994 pela Secretaria da Mulher da $\mathrm{UPCN}^{103}$ com trabalhadoras do setor público, foram determinadas as condutas dos conteúdos das mensagens de assédio que implicam ou não contato físico. Os tipos de assédios citados foram leve e verbal (conversações com conteúdo sexual, emails com conteúdo sexual não personalizados); moderado e não verbal e sem contato

\footnotetext{
${ }^{101}$ PAMPLONA FILHO, Rodolfo. Assédio sexual: questões conceituais. Jus Navigandi, Teresina, ano 09, $\mathrm{n}^{\mathrm{o}} 704,9$ jun. 2005. Disponível em: <http://jus2.uol.com.br/doutrina/texto.asp?id=6826>. Acesso em: 30.11.2009.

${ }^{102}$ LASSO. Lokee Alvaro. El Acoso Sexual en el Trabajo. Suplemento Ellas. La Prensa, viernes, 07 de mayo de 1999. Apud: WILSON STAFF, Mariblanca e MÉNDEZ ILLUECA, Haydée. Acoso Sexual: Un problema laboral. Panamá. Instituto de la Mujer de la Universidad de Panamá, 2002, (p.173).

${ }^{103}$ UPCN: Unión de Personal Civil de la Nación: violencia laboral. Estudio sobre acoso sexual, Secretaria de la Mujer de UPCN, Buenos Aires, (1997). Apud: OLIVARES ABAJO, Francisco Javier. Mobbing: Acoso psicológico en el ámbito laboral. Buenos Aires: Depalma, 2004, (pp.70-71).
} 
físico (olhares, gestos.); assédio forte com contato físico (manuseios, contatos físicos com clara conotação sexual) e assédio muito forte (pressões físicas ou psíquicas para obter contatos íntimos).

Para OLIVARES ABAJO ${ }^{104}$, o fenômeno do assédio sexual é muito mais complicado, porque depende de fatores como a cultura, o nível de educação, o contexto em que ocorre o assédio, a personalidade dos envolvidos e a percepção individual e personalíssima que cada um dos sujeitos tem do incidente ou da conduta.

Por outro lado é complicado também pela dificuldade de se produzir provas do fato, por diversas circunstâncias, uma delas é que o agressor se aproxima da vítima quando ela está sozinha e sem defesa, nesse caso as testemunhas são escassas. E porque geralmente as vítimas não denunciam seus agressores por causa das consequências da denuncia, dentre elas, estão as represálias e a perda do emprego.

O assédio sexual se classifica em duas espécies: assédio sexual por chantagem e assédio sexual por intimidação. O assédio por chantagem trata-se da exigência formulada por um superior hierárquico a um subordinado seu, para que se preste a uma atividade sexual se quiser conservar o emprego, garantir uma promoção ou até mesmo um aumento de salário. O assédio sexual por intimidação ocorre através de manifestações verbais de índole sexual, com o objetivo de afetar a atuação laboral da vítima tornando o ambiente hostil pela intimidação e pelo abuso. Essa última conduta é denominada também de "assédio sexual ambiental ${ }^{105 "}$. No assédio sexual ambiental, o "poder" é irrelevante, pois, os agressores são normalmente colegas de trabalho da vítima. O agressor destaca a sexualidade de forma insistente nos mais variados

\footnotetext{
${ }^{104}$ OLIVARES ABAJO. Francisco Javier. Mobbing: Acoso...Op. Cit. Nota anterior.

${ }^{105}$ ALKIMIN. Maria Aparecida. Violência na Relação de Trabalho... Op. Cit. Nota 33, (p.146).
} 
contextos, sendo indiscreto, inconveniente e ofensivo. Essa modalidade é conhecida na área laboral como "clima de trabalho" ou "clima de trabalho envenenado".

Neste escopo, não temos dúvida de que o assédio sexual é uma forma de discriminação contra o trabalhador ou trabalhadora. $\mathrm{O}$ direito à liberdade sexual diz respeito ao direito à intimidade e à vida privada, relacionado também ao direito à integridade física, que inclui o direito ao próprio corpo, logo, o assédio sexual fere os direitos humanos e sua conduta atenta contra a dignidade do trabalhador.

\subsubsection{O Assédio por Razão de Sexo}

Outro tipo de assédio ou violência que ainda acontece no ambiente de trabalho é o assédio por razão de sexo, um problema social que nos últimos anos as Organizações internacionais, os poderes públicos e os atores sociais tem se preocupado em erradicar. Essa forma de assédio, não se materializa com a finalidade sexual, como no caso do assédio sexual, mas sim, quando o assediador persegue, intimida ou discrimina a vítima em função do gênero. É importante destacar que a configuração do assédio como um comportamento discriminatório por razão de sexo deve ter uma relação de existência com o sexo da vítima, de maneira que isso seja a razão essencial da conduta do assediador, que ataca a vítima por ser mulher ou homem, diferentemente do assédio sexual que vimos anteriormente. Dentro disso, a jurisprudência do Tribunal Constitucional Espanhol vem considerando como discriminação direta o tratamento desfavorável a uma pessoa por razão única e exclusivamente sexual, atingindo assim, tanto os homens quanto as mulheres ${ }^{106}$.

\footnotetext{
${ }^{106}$ Nesse contexto, o profesor PALOMEQUE LÓPEZ, no libro: Derecho del Trabajo y Razón Crítica. Salamanca: Verona, 2004. (p.172), expõe que "en relación con el sexo, la prohibición de discriminación impide ciertamente la consideración de aquél como criterio de diferenciación en el ámbito del empleo y
} 
Frisamos que não estamos fazendo aqui referência a respeito da discriminação por orientação sexual, que configura também, uma violação dos direitos humanos e da dignidade do trabalhador. Todavia, não nos debruçaremos a respeito desse tema, que configura um campo fértil de pesquisa, carecendo de maiores discussões, principalmente no Brasil.

Mas, não podemos deixar de comentar o princípio da igualdade que é reconhecido nos Documentos internacionais mais relevantes, como na Carta das Nações Unidas (1945) e na Declaração Universal dos Direitos Humanos (1948). No caso na Carta das Nações Unidas de $1945^{107}$, se consagra o princípio da não discriminação no artigo $1^{\circ}$, parágrafo $3^{\circ}$ do artigo 55 , e também no artigo 76 . Em seu preâmbulo, faz referência da igualdade de direitos entre homens e mulheres. A Declaração Universal dos Direitos Humanos (1948) ${ }^{108} \mathrm{em}$ seu artigo $1^{\circ}$, assinala que "todos os seres humanos nascem livres e iguais em dignidade e direitos." No artigo $2^{\circ}$, consagra o princípio da não discriminação da seguinte maneira: "Todo ser humano tem capacidade para gozar os direitos e as liberdades estabelecidas nesta Declaração, sem distinção de qualquer espécie, seja de raça, cor, sexo, idioma, religião, opinião política ou de outra natureza, origem nacional ou social, riqueza, nascimento, ou qualquer outra condição”. Assim, fica claro que todos os Documentos citados, proíbem atitudes consideradas abusivas e que possam levar ao cometimento de crime de assédio, seja ele moral, sexual ou por razão de sexo. Não podemos esquecer ainda, da Convenção sobre a Eliminação de

\footnotetext{
las condiciones de trabajo (STC 28/1992), ya sea en su expresión más tosca donde el sexo es objeto de consideración directa ("tratamientos peyorativos", abiertos o incubiertos, que se fundan en la "pura y simple constatación del sexo de la víctima), ya en su vertiente indirecta ("más sutil y común"), la que tiene lugar bajo la apariencia de "tratamientos formalmente neutros o no discriminatorios" pero que encubren consecuencias perjudiciales (en atención a "razones o circunstancias" diversas que tienen una "conexión directa e inequívoca" con el sexo de la persona) para los miembros de un determinado sexo, generalmente femenino (SSTC 145/1991, 147/1995, 136/1996, 198/1996, 250/2000 y 41/2002).

${ }^{107}$ Carta das Nações Unidas. Disponível em <http://www2.ohchr.org/spanish/law/index.htm>. Acesso em 02.09.2009.

${ }^{108}$ Texto integral da Declaração Universal dos Direitos Humanos. Disponível em:<http://www.onubrasil.org.br/documentos_direitoshumanos.php>. Acesso em 01.02.2009.
} 
Todas as Formas de Discriminação Contra a Mulher, adotada pela Assembléia das Nações Unidas (1979), que diz em seu artigo $1^{\text {o109, }}$

a expressão discriminação contra a mulher, significará toda a distinção, exclusão e restrição baseada no sexo que tenha por objetivo ou resultado prejudicar ou anular o reconhecimento, gozo ou exercício pela mulher, independente do seu estado civil, com base na igualdade do homem e da mulher, dos direitos humanos e das liberdades fundamentais nos campos político, econômico, social, cultural ou civil ou em qualquer outro campo.

A discriminação que ocorre, em regra, em relação ao sexo feminino, tem raízes no comportamento social que acabou consolidando determinados conceitos e condutas conservadoras na vida familiar e na sociedade. A educação, em sentido estrito, herdada pelas gerações em sequência, não encoraja a mulher a buscar maior nível de conhecimento e ampliar a própria escolaridade, fazendo com que, ela assuma uma realidade distorcida, marcada pela falsa idéia de que, por ser feminina deva permanecer no lar, tomando conta dos afazeres domésticos e não tendo profissão fora de casa ${ }^{110}$. Isso leva muitas mulheres a entenderem o assédio como uma atitude normal, por se sentirem inferiores em relação aos homens.

Em alguns países desenvolvidos, a situação da diferença de salários entre homens e mulheres que exercem as mesmas funções não é muito diferente do Brasil. Mesmo sendo signatários da Convenção de $\mathrm{n}^{\mathrm{o}} 100$ da OIT $^{111}$ sobre igualdade de

\footnotetext{
${ }^{109}$ Esse Documento pode ser encontrado na página da Organização das Nações Unidas no link, Instrumentos Internacionais, disponível em: <http://www.unhchr.ch/spanish/html/intlinst_sp.htm>, Acesso em 11.02.2009.

${ }^{110}$ BARROS, Alice Monteiro de. Discriminação no emprego por motivo de sexo. Apud: VIANA, Márcio Tulio, RENAULT, Luiz Otávio Linhares et al. (Coords.). Discriminação. São Paulo: LTr, 2000, (pp.4849).

${ }^{111}$ Convenção n. ${ }^{\circ} 100$ da OIT relativa à Igualdade de Remuneração entre a Mão-de-obra Masculina e a Mão de obra Feminina no Trabalho de Valor Igual Adotada pela Conferência Geral da Organização Internacional do Trabalho na sua 34. ${ }^{a}$ sessão, em Genebra, a 29 de Junho de 1951. A OIT define discriminação dizendo que há um consenso sobre a discriminação no trabalho e que constitui uma
} 
remuneração, como no caso dos EUA e da Espanha, muitos países não respeitam os direitos das mulheres.

Destacamos na Espanha, a LOIMH de 22 de Março de 2007, que pretende criar uma igualdade efetiva entre homens e mulheres e traz em um de seus capítulos uma importante questão que é o "plano de igualdade para as empresas e outras medidas de promoção da igualdade ${ }^{112}$." Isso contribui para que as empresas atentem para as estratégias em seu âmbito de gestão na elaboração e na aplicação efetiva desse importante princípio do Direito: a igualdade de oportunidades e o direito a um tratamento não discriminatório.

Na América Latina, além do Brasil, a Costa Rica e o Chile tem índices significativos que demonstram a diferenciação da remuneração destinada a homens e mulheres. É um problema que os legisladores e os governos tem que enfrentar, desafiando o cenário de desigualdade que ainda é tão marcante. Esse tipo de assédio

violação de um direito humano que prejudica a produtividade e o crescimento econômico. Nos planos social e econômico, geram desigualdades que debilitam a coesão e a solidariedade sociais, além de dificultar a redução da pobreza. Significa que a eliminação da discriminação, tanto na legislação, quanto na prática, pressupõe promover a igualdade de oportunidades. O compromisso político de combater a discriminação e fomentar a igualdade de oportunidades no lugar de trabalho é praticamente universal, porque muitos países nos últimos anos tem ratificado os Convênios sobre a igualdade de remuneração $\left(\mathrm{n}^{\circ}\right.$ 100) e Sobre a discriminação (emprego e ocupação), (nº 111$)$.

${ }^{112}$ LOIMH 03/2007: para la igualdad efectiva de mujeres y hombres: Capítulo III. Los Planes de igualdad de las empresas y otras medidas de promoción de la igualdad. Artículo 45: Elaboración y aplicación de los planes de igualdad. 1. Las empresas están obligadas a respetar la igualdad de trato y de oportunidades en el ámbito laboral y, con esta finalidad, deberán adoptar medidas dirigidas a evitar cualquier tipo de discriminación laboral entre mujeres y hombres, medidas que deberán negociar, y en su caso acordar, con los representantes legales de los trabajadores en la forma que se determine en la legislación laboral. 2. En el caso de las empresas de más de doscientos cincuenta trabajadores, las medidas de igualdad a que se refiere el apartado anterior deberán dirigirse a la elaboración y aplicación de un plan de igualdad, con el alcance y contenido establecidos en este capítulo, que deberá ser asimismo objeto de negociación en la forma que se determine en la legislación laboral. 3. Sin perjuicio de lo dispuesto en el apartado anterior, las empresas deberán elaborar y aplicar un plan de igualdad cuando así se establezca en el convenio colectivo que sea aplicable, en los términos previstos en el mismo. 4. Las empresas también elaborarán y aplicarán un plan de igualdad, previa negociación o consulta, en su caso, con la representación legal de los trabajadores y trabajadoras, cuando la autoridad laboral hubiera acordado en un procedimiento sancionador la sustitución de las sanciones accesorias por la elaboración y aplicación de dicho plan, en los términos que se fijen en el indicado acuerdo. 5. La elaboración e implantación de planes de igualdad será voluntaria para las demás empresas, previa consulta a la representación legal de los trabajadores y trabajadoras.” Op. Cit. Nota 44. 
ainda é presente no mercado de trabalho no Brasil, como no caso das variações dos salários pagos a homens e mulheres. Quando se trata de promoções, os homens abrem considerável distância em relação às mulheres, chegando, no caso de cargos comissionados, a contratação livre pelo próprio administrador público. Os homens ainda recebem maiores salários do que as mulheres, segundo a pesquisa realizada pela Relação Anual de Informações Ministério do Trabalho e Emprego (RAIS) ${ }^{113}$. Em 2006, demonstrando que as mulheres ainda percebem $16,8 \%$ a menos de salário que os homens. Esse resultado se reflete em quase todos os estados brasileiros e a análise mostra, também, que há uma predominância de empregados do sexo masculino em diversos setores da atividade econômica. A pesquisa identifica um alto grau de desigualdade de oportunidades no trabalho, no emprego e na renda, principalmente para os grupos sociais submetidos à discriminação por razão de sexo como as mulheres ${ }^{114}$. É óbvio, que mulheres e os homens são diferentes, mas, enquanto pessoas e em especial, trabalhadores, devem ter os mesmos direitos. Esses direitos também estão relacionados ao de perceber salários iguais quando estiverem exercendo o mesmo cargo ou função e ascender as mesmas oportunidades de ascensão profissional. Esses direitos referem-se também, aos de competir no mercado de trabalho, de receber salários iguais aos dos homens quando estiverem exercendo o mesmo cargo que eles e de ascender as mesmas oportunidades profissionais.

\footnotetext{
${ }^{113}$ A RAIS é um censo anual do mercado de trabalho formal brasileiro que disponibiliza informações sobre o tipo de vínculo empregatício, salários, grau de instrução e nacionalidade dos trabalhadores, dentre outros.Os dados da Relação Anual de Informações Sociais - RAIS de 2006 são os mais recentes. O Ministério do Trabalho e Emprego recebe desde janeiro de 2008 as informações das empresas, com os dados do ano-base de 2007.

${ }^{114}$ ALKIMIN. Maria Aparecida. Violência na Relação de Trabalho...Op. Cit. Nota 33, (p.117), afirma que as mulheres acabam se tornando as maiores vítimas da violência nas relações trabalhistas, pois são discriminadas culturalmente, consideradas como o sexo frágil; há rejeição com grande escala da mulher quando da disputa de posições, funções ou cargos de destaque. A autora enfatiza ainda que as empresas que buscam produtividade e lucratividade, com redução de encargos priorizam o sexo masculino, pois a mulher por causa da maternidade tende a se ausentar, gerando substituição e rotatividade, que engendraria prejuízos à produtividade.
} 
Nesse diapasão, lembramos os Códigos de Conduta Empresarial que refletem os valores éticos das empresas, onde geralmente estão presentes temas como a não discriminação e a violência de gênero no ambiente laboral. Discutiremos a respeito do tema no capítulo III.

\subsection{As Consequências da Conduta de Assédio para o}

\section{Trabalhador e para a Empresa}

As consequências para o trabalhador que sofre o assédio moral, o assédio sexual ou o assédio por razão de sexo são muitas, porém, não é somente ele que sofre, a empresa e a sociedade também pagam o preço por essas condutas perversas no ambiente de trabalho. Acreditamos que a primeira dificuldade é a identificação pela vítima de que está realmente sofrendo algum tipo de assédio. Normalmente, o trabalhador demora a reconhecer que está sendo assediado, principalmente no quando se trata de assédio moral, bem mais sutil e silencioso. Muitas vezes, o assediado sente-se culpado e se pergunta: será que isso é normal? Será que mereço um tratamento assim? Ou ainda: Será que estou fazendo meu trabalho direito?

A saúde do trabalhador é afetada, podendo apresentar quadros de depressão, estresse, distúrbios psicossomáticos, ansiedade, apatia, tristeza, nervosismo, desesperança, sentimento de culpa, crises de auto-estima, transtornos emocionais e sociais, conflitos familiares e transtornos do sono. No ambiente de trabalho, apresenta queda da produtividade, perda da motivação e da criatividade e absenteísmo. Geralmente, o assediado começa a ter dificuldade de relacionamento, 
pois tende a se isolar, associando o trabalho como um ambiente hostil e de sofrimento.

A empresa também é afetada quando ocorrem problemas de assédio ou violência no ambiente de trabalho. Em consequência disso, a produtividade cai, a falta de comunicação dificulta a transmissão e a execução das tarefas, a qualidade do trabalho diminui, há queda na produtividade e alteração na qualidade do serviço/produto, a eficiência no trabalhado diminui, se manifestam as doenças profissionais e os acidentes de trabalho, ocorrem danos aos equipamentos, alta rotatividade de mão-de-obra e queda na lucratividade. Dessa maneira, o clima organizacional fica tomado de desconfiança, insegurança e medo. Em termos de lucro e negócios, a empresa acaba perdendo a referência e tem sua imagem denegrida. Com isso, as partes interessadas - clientes, acionistas, fornecedores e parceiros, perdem a confiança na sua administração e gestão. Por outro lado, o empregado, que é vítima do assédio, além do dano psicológico, pode sofrer enfermidades que necessitam de acompanhamento médico e as demandas trabalhistas aumentam com pedidos de reparação por danos morais, gerando gastos para a empresa.

O assédio no trabalho projeta efeitos negativos também à sociedade, uma vez que o Estado deve arcar com elevados custos no que refere à saúde pública, à assistência e à previdência social, com tratamentos de reabilitação profissional. Deve ainda, conceder benefícios em razão de afastamento por licença saúde dos trabalhadores afetados. Sem dúvida, esse é um problema que exige a intervenção dos poderes públicos, dada a gravidade das consequências dos trabalhadores que sofrem, 
dos custos elevados que acarretam nas economias das empresas e o dano que afeta o sistema de saúde pública.

Segundo ESCUDERO MORTALLA ${ }^{115}$, um estudo realizado pela National Safe Workplace Institute estimou que o custo das empresas americanas com a violência no trabalho se elevou no ano de 1992 para quatro milhões de dólares. No Canadá, a British Workers Compensation Board denunciou que os gastos hospitalares de obreiros, devido à violência nos postos de trabalho, aumentaram 88\% desde 1985. Já o informe da Organização Internacional do Trabalho, dos professores HELGE HOEL, KATE SPARKS y CARY L. COOPER, revela que, a cifra do custo global de estresse e violência no trabalho em percentagem, é entre 01 e 3,5\% do Produto Interno Bruto de um país desenvolvido. Sendo assim, é importante que as empresas atentem para a prevenção de qualquer tipo de assédio no âmbito do trabalho. Para tanto, devem contar com um setor de recursos humanos capaz de orientar, detectar e solucionar casos de assédio.

\footnotetext{
${ }^{115}$ HELGE HOEL, KATE SPARKS y CARY L. COOPER. Apud: ESCUDERO MORATALLA J.F. y POYATOS i MATAS, G. Mobbing: Análisis multidisciplinar y estrategia legal. Barcelona: Bosch, 2004 (p.139).
} 


\section{CAPÍTULO III}

\section{GESTÃO EMPRESARIAL E OS DIREITOS HUMANOS}

\subsection{A Ética e os Códigos de Conduta Empresariais}

Nos hace falta una nueva manera de ver la ética y la gestión empresariales, con más compasión y menos fe ciega en la "magia" de los mercados.

Ban Ki-moon

(Secretário Geral das Nações Unidas - 09/2008).

Esse capítulo tem por objetivo visualizar a necessidade das empresas de trabalharem na proteção dos Direitos da pessoa humana. Analisaremos as iniciativas e os Documentos internacionais de proteção que recomendam as organizações empresariais a assumirem o compromisso de agir em prol do respeito aos Direitos Humanos e as ações preventivas utilizadas como ferramentas para inibir a violência e o assédio no ambiente de trabalho.

Nunca o mundo corporativo esteve tão atento à concorrência e a competitividade como hoje em dia. Alguns fatores importantes na busca desses itens são a produtividade com a maior rapidez, a terceirização e a flexibilidade dos serviços. Dessa maneira, os trabalhadores devem adaptar-se a essas exigências em que a urgência fala mais alto. Parece-nos que não se tem mais tempo de escutar, a comunicação é falha, a pressa é a palavra chave. Geralmente, quando estamos sendo pressionados, cobrados e 
com prazos estipulados para executar as tarefas no trabalho, esquecemos dos outros e, com frequência, acabamos culpando-os pelas nossa falhas. Fazemos qualquer coisa para não perder tempo e cumprir as tarefas no prazo estabelecido, que é geralmente curto demais. Ser admitido em uma empresa significa aceitar seus valores, seus princípios e seu modo de trabalhar. Elas procuram sujeitos adaptáveis, criativos e polivalentes que se ajustem facilmente aos seus moldes de trabalho. Não basta ser mais um funcionário, tem que ser um parceiro, um colaborador, já que o paradigma imposto é o de que o sucesso da empresa depende dos "colaboradores" saberem se auto-relacionar com suas capacidades de viver, de aprender, de capitalizar e de atualizar conhecimentos. Nesse sentido, a vida de cada um se confunde com a vida econômica da empresa ${ }^{116}$. Hoje em dia, ficar muito tempo em um mesmo cargo ou posto é sinal de acomodação, falta de criatividade ou preguiça. Para evitar essa situação, não basta ser bom, tem que ser o melhor, tem que ter "jogo de cintura", nem que para tanto, seja preciso esquecer da ética, do bom senso e, especialmente, dos outros. Cabe lembrar, que os negócios se relacionam às estratégias organizacionais que, por sua vez, aparecem retratadas nas metas que os trabalhadores tem de cumprir. Muitas vezes, para que uma meta seja cumprida tal como foi estipulada, ou, até mesmo para ser superada e levar o trabalhador a ter reconhecimento ou mérito, muitas condutas não éticas podem ocorrer ${ }^{117}$. Nas palavras do consultor organizacional Henrique PISTILLI ${ }^{118}$,

\footnotetext{
Estamos cada vez mais conectados com o mundo e menos conectados com nós mesmos, menos conectados com nossas prioridades e senso de direção individual. Assim, aceitamos tudo, nos submetemos a muitas coisas. Buscamos ser um super-executivo, $99 \%$ profissional e $1 \%$ pessoal, absorvendo assim o mesmo padrão no nível individual:

${ }^{116}$ BARRETO. Margarida. Violência, Saúde...Op. Cit. Nota 88, (p.102).

${ }^{117}$ FARIA. Maria de Fátima Bruno de. Gestão de Pessoas. Universidade de Brasília. Centro de Educação à Distância, Brasília (DF), 2006, (p.53).

${ }^{118}$ Entrevista dada a jornalista Patrícia Bispo. Disponível em: <http://www.rh.com.br. Acesso em 16.12.2009.
} 
acúmulo de recursos é segurança e desenvolvimento. Falta tempo para pensar em si mesmo, para criar a intenção da própria existência individual. Tempo para sonhar alto com o "ser" integrado com o "ter". O resultado é visível: estresse, ansiedade, pânico, apatia, desesperança no futuro, endividamento, frustração, exaustão. Trabalha-se, trabalhase, trabalha-se (...).

Nesse sentido, HIRIGOYEN diz que, o assédio pode se desenvolver nos meios em que prevalecem um intenso nível de estresse e onde não há organização, e sobretudo, onde as práticas de gestão são pouco claras ou perversas, constituindo-se assim, em uma autorização implícita às atitudes perversas individuais ${ }^{119}$. Por isso, as ações ou princípios éticos sobre competitividade e lealdade implantados pela empresa e seu acompanhamento, são fundamentais para que o ambiente de trabalho não se transforme em um terreno fértil para a violência e o assédio.

Atualmente, o lucro nos negócios já não é condenado, e as empresas já não são vistas como monopólios sem rosto e sem alma. A nova preocupação é como esse lucro deve ser concebido no contexto mais amplo da produtividade e da responsabilidade social ${ }^{120}$. Nesse sentido, atos de grande repercussão foram ajudando a consolidar a noção de que o lucro poderia e deveria se submeter à princípios éticos, são exemplos: as leis norte-americanas: Sherman Act de 1890, que tem explícitos os preceitos éticos que devem ser ampliados no relacionamento da empresa com seus concorrentes e a Foreign Corrupt Practices Act (FCPA) de 1977, que estabelece penalidades para pessoas ou Organizações que oferecem subornos a autoridades estrangeiras para obter negócios ou contratos. Em 1972, a ONU realizou em Estocolmo, a primeira Conferência Internacional sobre o Meio Ambiente, visando à preservação do

\footnotetext{
${ }^{119}$ HIRIGOYEN. Marie France. Mal-Estar no Trabalho... Op. Cit. Nota 98, (p.187)

${ }^{120}$ SOLOMON. Robert. C. A Ética Empresarial. Artigo retirado de A Companion to Ethics. Universidade do Texas, Austin, 1993. Disponível em: http://www.eticaempresarial.com.br/. Acesso em 18.12.2009.
} 
planeta, estabelecendo princípios éticos aplicáveis as atividades empresariais e tendentes a proteger o meio ambiente, a saúde a segurança dos seres humanos. Desde então, as empresas e os Organismos internacionais começaram a colocar em pauta a questão da ética nos negócios, estabelecendo regulamentos e códigos de conduta no que se referem aos princípios éticos que devem ser observados na relação com os clientes, fornecedores, concorrentes, empregados, governantes e sociedade em geral.

Mas então o que é ética? Ela diz respeito à reflexão sobre os princípios que norteiam a ação e que diferenciam o bem (correto) do mal (incorreto). Assim, um passo fundamental para o exercício ético, é tirar a questão ética da sombra do “implícito” e colocá-la `a luz do debate. A Ética é um conjunto de princípios e valores que guiam e orientam as relações humanas. Esses princípios devem ter características universais e precisam ser válidos para todas as pessoas e para sempre. A definição mais simples é aquela que diz que a ética é um conjunto de valores, de princípios universais que regem a relação das pessoas. A ética é muito mais ampla, geral e universal do que a moral. A ética tem a ver com princípios mais abrangentes, enquanto que, a moral se refere mais a determinados campos da conduta humana. A ética dura muito mais tempo que a moral, os costumes prendem-se mais a determinados períodos e culturas. Mas uma nasce da outra ${ }^{121}$.

Toda Organização tem um Código de Ética que busca refletir comportamentos desejados para o ambiente de trabalho e que deve retratar valores discutidos e compactuados pela administração da Organização, com o objetivo de serem traduzidos nas ações do dia a dia da empresa. O Código de Ética é um instrumento redatado pela empresa, no qual se fundamenta pelos seus valores e princípios, que ajuda

\footnotetext{
${ }^{121}$ SOUZA, 1994, (p. 13). Apud: AHLERT, Alvori. Ética e Direitos Humanos: princípios educacionais para uma sociedade democrática. Nómadas. Revista Critica de Ciencias Sociales y Jurídicas. 16, 2007.2. Artigo disponível em: http://www.ucm.es/info/nomadas/.
} 
a concretizar sua visão e missão. A ética vai além dos requisitos legais a serem cumpridos pela empresa, tem relação com as decisões discricionárias e com o comportamento baseado em valores. Dissemos então, que a ética empresarial tem relevância na conduta e no comportamento com seus stakeholders, ou seja, com todo o grupo com quem a empresa possui relacionamentos ao longo de sua atividade diária: empregados, fornecedores, clientes, acionistas, comunidade e governo (regional, nacional e reguladores). Para o Banco do Brasil a Ética Corporativa "compreende princípios, padrões e regras de conduta de natureza moral que orientam o processo de tomada de decisão da organização. Trata-se de postura empresarial que condiciona o alcance dos objetivos organizacionais, notadamente o resultado econômico, ao respeito às pessoas, ao ambiente e às instituições. Trata-se de questão basilar dos princípios de responsabilidade social empresarial ${ }^{122, "}$.

Já o Código de Conduta de uma empresa é um guia com as regras orientadoras de atuação e as práticas organizacionais, onde os princípios do Código de Ética são detalhados. O Código de Conduta trata de temas como a legislação, o meio ambiente, a corrupção, a confidencialidade e o assédio. O Documento é geralmente elaborado e destinado aos trabalhadores e seu enfoque, é mais centrado em regras de conformidade. Nesse sentido, a participação dos stakeholders e a transparência do Código de Conduta, são a chave para evitar possíveis dúvidas em relação às regras e princípios da empresa. Uma vez redatado e aprovado por todos os participantes, o Documento deve ser difundido, para que todos se sintam responsáveis pelo seu conteúdo. É importante dizer que, o Documento deve ser revisado, ampliado ou

\footnotetext{
${ }^{122}$ Web Site da empresa: http://www.bb.com.br. Acesso em 17.12.2009.
} 
modificado ao longo do tempo. Em relação a isso, AGULLÓ GIMENO ${ }^{123}$ acrescenta que "La sociedad va evolucionando y la empresa debe saber adaptar-se a los tiempos y comprender los nuevos retos morales. Las situaciones y motivos que requieren de una propuesta ética varian y de ahí que se necesite hacer revisiones periódicas del código desde una reflexión propia de un nível de conciencia moral postconvencional para que sea una referencia siempre vigente."

Para tanto, devem-se traçar normas ou regras que regulem o comportamento ético das pessoas, tornando-as explícitas. Os Códigos de Ética devem ser ferramentas eficazes de gestão e, para isso, a empresa deve fortalecer e divulgar os valores já existentes, revisando outros e criando uma nova consciência. É aí, que entra a área de Recursos Humanos ou Gestão de Pessoas da empresa, fundamental porque é ela quem semeia a importância da Ética, adotando-a como um valor institucional, convocando todos os níveis hierárquicos da organização para que participem democraticamente da elaboração e da implantação de um Código de Conduta interno. Essa é uma forma para que todos se comprometam com os valores e a missão da empresa e se tornem responsáveis pelo acompanhamento desses princípios. Outro importante papel do setor de gestão de pessoas é a comunicação que ele faz entre os distintos segmentos da empresa, atuando como um intermediário, deixando de lado a fama de ser meramente operacional, já que sua missão principal é a demissão ou a ação disciplinar.

Em relação às manifestações disciplinares é importante salientar que a relação empregado/empregador deve ser estabelecida dentro dos princípios do Código de Ética e também dentro da lei. A CLT reza que, o empregador é aquele que admite,

\footnotetext{
${ }^{123}$ AGULLÓ GIMENO, Silvia. La Coherencia Ética en la Gestión de los Recursos Humanos: un factor clave para la forja del ethos corporativo. Tese. Barcelona (ES), 2009, Universitat Ramon Llull, Departamento Gestión Empresarial, (p.79).
} 
assalaria e dirige a prestação pessoal de serviço $\left(\right.$ art. $2^{\circ}$ ) e, por sua vez, o empregado é aquele que presta serviços de natureza não eventual ao empregador, sob a dependência deste e mediante salário (art. $3^{\circ}$ ). Em função disso, o empregador tem poder diretivo em relação ao empregado. Porém, o primeiro limite em relação a esse poder é que as ações disciplinares devem ser exercidas de forma responsável e coerente, baseado em preceitos éticos que devem reger todas as relações humanas. Qualquer manifestação desse poder deverá sempre ter como limite o respeito à dignidade do trabalhador.

O Código de Ética ou de conduta de uma empresa deve ser um instrumento efetivo de determinação de princípios de conduta e deve agregar valor à Organização. E, somente se tornarão eficazes, se estiverem acompanhados de uma política clara e amplamente aplicável. A Ética consiste numa reflexão crítica que permite a escolha da melhor forma de agir. Essa reflexão tem por objeto a moral, os valores e os princípios que na prática estabelecem as regras do agir em recursos $\operatorname{humanos}^{124}$.

Nesse sentido, VARELLA enumera uma série de princípios morais que podem fazer parte de um Código de Conduta empresarial. Ele enumera alguns temas relacionados às ações típicas da área de gestão de pessoas, como por exemplo:

a) Na seleção de pessoas os processos devem oferecer oportunidades iguais para todos sem discriminação de cor, raça, sexo, religião e nacionalidade, aparência, idade, orientação, sexual, deficiência física, estado civil ou posição social;

b) Deve-se ter compromisso com os valores (as pessoas devem ser selecionadas também pelo alinhamento com os valores da organização);

\footnotetext{
${ }^{124}$ VARELLA, João Marcos. Ética e Recursos Humanos. Apud: BOOG, Gustavo e BOOG, Magdalena. Manual de Gestão de Pessoas e Equipes: estratégias e tendências. Vol. I. São Paulo: Gente, 2002, (p.50).
} 
c) A avaliação das pessoas deve ser imparcial e o senso de justiça deve prevalecer;

d) O feedback deve ser fornecido em condições de respeito e nas relações trabalhistas é preciso garantir representatividade dos trabalhadores da empresa e a liberdade da organização de atividades associativas;

e) $\mathrm{O}$ respeito aos direitos dos empregados e o cumprimento dos acordos firmados são essenciais;

f) A demissão deve ser digna e a comunicação feita com privacidade, contando com um apoio, sempre que possível, de recursos e orientação para a continuidade da carreira;

Demonstra-se que a postura ética da empresa com as pessoas deve estar presente desde o processo de seleção até a possível demissão do funcionário. Outras ações importantes que devem ser monitoradas pelo setor de gestão de pessoas da empresa, são:

a) $\mathrm{O}$ relacionamento entre as pessoas que deve se desenvolver em condições para criar um clima produtivo e agradável de trabalho, através da qualidade do relacionamento, onde as pessoas e suas idéias devem ser tratadas com dignidade e respeito;

b) $\mathrm{O}$ respeito específico à individualidade e às características pessoais de cada um; os cuidados com o ambiente físico, já que as condições materiais de trabalho precisam garantir à segurança e à saúde do trabalhador; os cuidados com a vida pessoal onde se revela importante o equilíbrio entre a vida profissional e pessoal de forma a permitir a realização integral do trabalhador como pessoa humana, preservando- 
lhe a vida privada e espaço para o desenvolvimento de projetos sociais de maneira que se possa assegurar a manutenção e gozo de boa saúde;

c) A responsabilidade social, onde se possa patrocinar e estimular a participação das pessoas em atividades comunitárias e de incentivo à cidadania;

d) O fomento à comunicação, mantendo mecanismos de mão dupla, abertos, acessíveis, entre a organização e seus colaboradores;

e) O comportamento adequado capaz de criar um ambiente íntegro, justo e de respeito mútuo não compatível com favores, subornos, chantagens, vantagens em ganhos ilícitos e, tampouco, compatíveis com violência verbal e ações que prejudiquem as demais pessoas e outras formas de violência e assédio no ambiente de trabalho $^{125}$

As ações ou princípios citados pelo autor podem ser realizadas, também, por outros setores da empresa, e seguidas por cada equipe ou setor de trabalho. Elas ajudarão a desenvolver um clima saudável no trabalho, inibindo o quadro hostil e dificultoso do ambiente, que poderia gerar condutas tendentes ao assédio.

A tendência das grandes companhias, citamos aqui, as das empresas multinacionais $^{126}$, em especial, é de tutelar os diretos fundamentais dos trabalhadores, transferindo essa responsabilidade que seria do Estado para a iniciativa privada, invocando a idéia da atuação social responsável e redimensionando o princípio da

\footnotetext{
${ }^{125}$ Ações de gestão de pessoas decorrentes dos princípios de um código de ética. Fonte adaptado de VARELLA. Op. Cit. Nota anterior (pp.131-135).

${ }^{126}$ Utilizaremos a partir daqui as denominações empresas multinacionais (que podem estar baseadas em um país, mas ter bases em outros países para fins de gerência, fabricação ou distribuição), transnacionais (têm sua matriz em um país, mas grande parte de suas operações ocorrem em outros países, que não os de origem) ou comerciais (são intermediárias entre produtor e consumidor, sua função principal é a compra e venda de produtos). Cujo o conceito jurídico mais aprofundado de cada uma não é importante para o objetivo desse trabalho.
} 
subsidiariedade ${ }^{127}$. As empresas assumem assim, a responsabilidade social e garantem os direitos sociais dos trabalhadores quando prevêem também a defesa dos direitos humanos através de seus Códigos de Conduta ${ }^{128}$.

A OIT examinou doze programas de etiquetas sociais ${ }^{129}$ e duzentos e quinze códigos de conduta procedentes de grandes empresas, sindicatos e ONGs. $80 \%$ pertencentes a empresas multinacionais. O estudo centrou-se nas práticas laborais à luz dos princípios e direitos fundamentais internacionalmente reconhecidos, como: a liberdade de associação, o direito à negociação coletiva, a eliminação de todas as formas de trabalho forçado ou obrigatório, a erradicação do trabalho infantil e a eliminação da discriminação em matéria de emprego e ocupação. A análise constatou que, os códigos e programas de etiquetas sociais eram seletivos quanto à incorporação desses direitos ${ }^{130}$. Somente um terço dos códigos examinados fazia referência às normas internacionais do trabalho em geral, ou mencionava especificamente os princípios do convênio ou recomendação da OIT. As referências das normas da OIT eram mais frequentes nos

\footnotetext{
${ }^{127}$ Em termos gerais, o princípio da subsidiariedade visa garantir um determinado grau de autonomia a uma autoridade subordinada, face à uma instância superior, ou a um poder local face ao poder central. Trata-se de uma repartição de competências entre diversos níveis de poder, princípio que constitui a base institucional dos Estados federais. No caso, a empresa é tida como iniciativa privada que elabora seus estatutos e regimentos internos com o intuito de fazer valer os direitos dos trabalhadores, o que seria uma obrigação inicial do Estado.

${ }^{128}$ ALKIMIN. Maria Aparecida. Assédio Moral .Op. Cit. Nota 86, (p.164). Acrescenta ainda que "O código de conduta se caracteriza como um documento voluntariamente adotado pela empresa, visando praticar uma política empresarial comprometida com a ética e a responsabilidade social, elaborado de acordo com os valores da empresa, leis, tratados e resoluções internacionais, visando o respeito e promoção dos direitos humanos (...) praticando a verdadeira cidadania empresarial, através da divulgação e colocação em prática da legislação internacional de proteção aos direitos humanos".

${ }^{129}$ Os programas de Labelling social, etiquetas ou selos sociais funcionam como sistemas de verificação nas ações da empresa, por meio visível, contendo as condições laborais e sociais em que se desenvolve a fabricação de um produto ou marca, facilitando a informação por meio de uma etiqueta física, podendo ser colocada nos produtos ou nas embalagens destinadas aos consumidores e/ou a possíveis sócios comerciais.

${ }^{130} \mathrm{O}$ estudo constatou que $75 \%$ dos códigos de conduta das empresas analisadas tratava de assuntos relacionados com a segurança e a saúde no trabalho. 2/3 tratavam da discriminação na contratação de seus empregados, $45 \%$ trazia a erradicação o trabalho infantil como meta, $40 \%$ tratava da questão dos níveis salariais. $25 \%$ dos códigos analisados discorria sobre a eliminação do trabalho forçado. $\mathrm{O}$ estudo destacou que somente $15 \%$ dos códigos analisados as empresas chamavam a atenção de direitos como: o da liberdade de associação, de sindicalização e de negociação coletiva. Direitos esses fundamentais para o desenvolvimento e funcionamento dos sindicatos. Informações retiradas do documento OIT/G.B. 273/WP/SDL/1. Genebra (1998).
} 
códigos de elaboração conjunta (empresa e trabalhadores). A análise ressalta ainda, que muitos dos códigos das empresas que se consideram como pioneiras no âmbito da responsabilidade social não faziam menção alguma sobre as normas internacionais do trabalho ou sobre os instrumentos da OIT para prever ações de assédio ou para respeitar os direitos dos trabalhadores reconhecidos internacionalmente.

A Confederação Internacional de Organizações Sindicais Livres $\left(\right.$ CIOSL $\left.^{131}\right)$, criada em 1949, conta com 241 Organizações filiadas em 156 países e territórios, inclusive, entidades Européias e sindicatos globais, que congregam internacionalmente sindicatos nacionais. Entre suas linhas de atuação estão, a garantia do e no emprego e das normas de trabalho internacionais, a ofensiva contra as empresas internacionais que as desrespeitam, os direitos sindicais, os direitos relacionados à igualdade, os direitos das mulheres, os relacionados à raça e os direitos dos imigrantes. O Código de Práticas Trabalhistas adotado pela Entidade em 1997, tem por objetivo promover as normas trabalhistas internacionais e a inclusão dos direitos sindicais nos Códigos de Conduta das empresas e, ainda, tenciona ser usado pelos sindicatos e empresas como modelo de requisitos básicos ou normas mínimas que devem ser observadas. O Código básico da CIOSL faz menção aos direitos fundamentais do trabalhador, abordando o salário justo, a jornada de trabalho de 48 semanais, as horas extras voluntárias, as condições de trabalho decentes, o ambiente de trabalho seguro e higiênico, entre outros. A Entidade acredita que os Códigos de Conduta não podem ser vistos de forma isolada e devem prever formas de implantação e avaliação, envolvendo também os sindicatos, já que eles são as Organizações que representam os trabalhadores.

\footnotetext{
${ }^{131}$ Para saber mais: <http://www.icftu.org>. Acesso em 02.01.2010.
} 
O olhar crítico dos sindicatos a respeito dos Códigos de Conduta empresariais é de que a maioria dos Documentos padecem de uma série de defeitos, não fazem referência à liberdade sindical ou à negociação coletiva; são estabelecidos sem prévia consulta aos sindicatos ou à outras partes interessadas, são vagos e utilizam definições "caseiras", ao invés, de sustentar-se em definições elaboradas e negociadas por Entidades competentes como a OIT; não estabelecem mecanismos de monitoramento ou de implementação; tratam apenas de temas nos quais as empresas sentem-se vulneráveis, sem considerar as prioridades das partes interessadas; não são divulgados nos países onde ocorrem as maiores violações, entre outros ${ }^{132}$.

Para tanto, é importante atentar, para a eficácia desses Códigos e, verificar se eles prevêem algum tipo de fiscalização ou monitoramento. No que respeita aos Direitos Humanos há necessidade de uma verificação contínua do cumprimento dos Códigos, realizada de acordo com normas definidas e reconhecidas ${ }^{133}$. Há empresas que adotam os Códigos de Conduta externos, onde a sociedade geral tem acesso ao conteúdo. Esses Documentos estão sujeitos a certificação externa do ISO 8.000 (Internacional Organization for Standardization), que é a certificação da responsabilidade social. Já, a SA 8.000 da Social Accountabilily International ${ }^{134}$, como norma internacional, é a que define os requisitos referentes as práticas sociais do emprego por fabricantes e fornecedores. Algumas empresas interessadas em comprovar

\footnotetext{
${ }^{132}$ Instituto Observatório Social. Responsabilidade Social...Op. Cit. Nota 18, (p.74).

${ }^{133}$ Em janeiro de 1999 o Parlamento Europeu aprovou uma Resolução sobre as normas da União Européia para as empresas que operam em países em desenvolvimento para se criar um Código de Conduta Europeu. A Normativa insita os empresários e trabalhadores a criarem um Código de Conduta voluntário baseado nas normas e nas regras internacionais mais relevantes. Redata: "Aprova e encoraja as iniciativas voluntárias desenvolvidas pelas empresas, indústrias, sindicatos e associações de ONGs para promover códigos de conduta, com um acompanhamento e verificação efetivos e independentes e a participação dos parceiros no desenvolvimento, na implementação e no controle de códigos de conduta; sublinha igualmente que os códigos de conduta não podem substituir nem suplantar a regulamentação nacional ou internacional aplicável e a responsabilidade própria dos governos; entende que os códigos de conduta não devem ser utilizados como instrumentos para furtar as empresas multinacionais de qualquer tipo de controle administrativo ou judicial"'. Ver documento na íntegra:<http://www.europarl.europa.eu>. Acesso em 30.12.2009.

${ }^{134}$ Disponível em: <http://www.sa-intl.org>. Acesso em 30.02.2009.
} 
o atendimento aos requisitos dessa Norma são submetidas a auditorias por técnicos especializados de renomadas entidades independentes. Acreditamos que a iniciativa é importante, uma vez que, os conteúdos enunciados nos Códigos e a atuação prática da empresa devem estar em conformidade. Mais adiante, veremos essa Norma de forma mais detalhada.

O acompanhamento ou monitoramento do Código de Conduta e de Ética da empresa realizadas pelos seus stakeholders, sindicatos e ONGs, é uma forma de obrigar as empresas a reconhecer sua responsabilidade em relação à proteção dos Direitos Humanos e, em especial, dos Direitos Humanos dos trabalhadores. Além dessas Cartas de intenções, existem outras iniciativas voluntárias que as empresas adotam a fim de proteger tais direitos, que analisaremos a seguir.

\subsection{Os Diretos Humanos}

Para que possamos entender os Direitos Humanos, devemos refletir sobre a definição, porque, o que vemos não é um consenso claro e definido por filósofos, sociólogos, juristas, historiadores, teólogos e pesquisadores da área. Portanto, não vamos nos deter em áreas específicas, mas, analisar os vários entendimentos a cerca dos Direitos Humanos de forma histórica e independente.

No fim do século $\mathrm{XV}$, surgiu um fato que teve, sem dúvida, grande importância para o Direito Internacional Público: o descobrimento da América. Nessa época, já havia na Europa, diversos Estados independentes. Os teóricos e fundadores da doutrina "O Direitos das Gentes" foram os juristas de Direito Canônico, e alguns teólogos, entre os quais, se salientou um dominicano espanhol conhecido como Francisco de Vitória. Esse doutrinador, que professava a teologia na Universidade de 
Salamanca, contribuiu de forma decisiva para a noção da prevalência do Estado de Direito. A concepção de VITORIA, em "O Direito das Gentes" regulava uma comunidade internacional constituída de seres humanos organizados socialmente em Estados que coexistiam com a própria humanidade ${ }^{135}$. A reparação das violações dos Direitos Humanos refletia, para ele, uma necessidade internacional a ser suprida pelo Direito das Gentes, observando-se os mesmos princípios de justiça tanto para os Estados como para os indivíduos. Transcorridos mais de quatro séculos e meio, sua mensagem retém uma notável atualidade.

Em conformidade com a moderna doutrina, os Direitos Humanos apresentam as seguintes características: imprescritibilidade; inalienabilidade; irrenunciabilidade; inviolabilidade; universalidade e indivisibilidade. De forma bastante resumida, dissemos que, uma vez violados, podem ser exigidos em qualquer tempo, não podem ser objeto de alienação ou transferência e a pessoa não pode deles dispor, por ser inerente ao ser humano. A inviolabilidade reflete, a obrigação de respeito pelas determinações infraconstitucionais ou por atos das autoridades públicas que possam prejudicar esses direitos. Já a universalidade, demonstra que, a abrangência desses direitos englobam todos os indivíduos, independentemente de nacionalidade, raça, sexo ou convicção político-filosófica. Os Direitos Humanos devem ainda, ser efetivos, ou seja, o poder público precisa garanti-los através da sua atividade legislativa e das políticas públicas ativas e passivas capazes de protegê-lo. E, por último, dissemos que eles são indivisíveis, porque contém um leque inseparável de proteção.

\footnotetext{
${ }^{135}$ Obras de Francisco de Vitoria: Relecciones Teológicas, Ed. T. Urdanoz, Madrid, BAC, 1960, (p. 675). Apud: CANÇADO, Antonio Augusto Trindade. $O$ Direito Internacional em um mundo em transformação. São Paulo: Renovar, 2002, (p.540).
} 
Os Direitos Humanos envolvem ainda, os direitos e liberdades das pessoas. Na Declaração Universal dos Direitos do Homem da Organização das Nações Unidas é possível perceber, em seu artigo $1^{\circ}$, que “Todos seres humanos nascem livres e iguais em dignidade e em direitos. Dotados de razão e consciência, devem agir uns para com os outros em espírito de fraternidade. Para alguns doutrinadores, a origem desses direitos de liberdade vem do conceito filosófico do direito natural que defende a idéia de que eles seriam atribuídos por Deus. Para outros, esses direitos seriam concedidos pelo Estado através das leis que ele elabora. Isso pode ser percebido em algumas definições de Direitos Humanos, trazidos por estudiosos como MELLO ${ }^{136}$,

Direitos do homem [...] aqueles que estão consagrados nos textos internacionais e legais, não impedindo que novos direitos sejam consagrados no futuro. [...] os já existentes não podem ser retirados, vez que são necessários para que o homem realize plenamente a sua personalidade no momento histórico atual.

Já, para o grande catedrático espanhol de Filosofia do Direito, PÉREZ LUÑO $^{137}$, os Direitos Humanos podem ser assim definidos:

Los derechos humanos aparecen como un conjunto de facultades e instituciones que, en cada momento historico, concretan las exigencias de la dignidad, la libertad y la igualdad humanas, las cuales deben ser reconocidas positivamente por los ordenamientos jurídicos a nível nacional e internacional.

É importante salientar, que o autor descreve os Direitos Humanos “em cada momento histórico", pois, eles se modificam e se expandem, dependendo do momento em que se encontra a civilização, evoluindo de acordo com a humanidade.

\footnotetext{
${ }^{136}$ MELLO, Celso D. de Albuquerque. Curso de Direito Internacional Público. $13^{\mathrm{a}}$ edição, Rio de Janeiro: Renovar, 2001, (p.770).

${ }^{137}$ PÉREZ LUÑO, Antonio. Derechos Humanos, Estado de Derecho y Constitución. 9a edición. Madrid: Tecnos, 2005, (pp.50-51).
} 
Dessas duas definições, salientamos que, os autores utilizam expressões como "momento histórico" e "ordenamentos jurídicos". Nesse sentido, ARENDT ${ }^{138}$ chamava a atenção para o fato de que os homens não nascem livres e iguais e a liberdade e a igualdade são opções políticas. O ser humano em algum momento histórico buscou construir instrumentos para garantir os Direitos Humanos na luta contra a opressão. Assim, esses direitos com o tempo foram se expandindo e se modificando. De acordo com ela, esses direitos só seriam garantidos na prática, quando o Estado se manifestasse, sendo através das políticas públicas ou então, com a elaboração de regras capazes de efetivá-los.

Para o constitucionalista português e professor na Universidade de Coimbra, CANOTILHO "As expressões direitos do homem e direitos fundamentais são frequentemente utilizadas como sinónimos (...) os direitos do homem são direitos válidos para todos os povos e em todos os tempos (dimensão jusnaturalista e universalista". Ele menciona que a universalidade dos Direitos Humanos é uma de suas características e diz que os direitos referidos são universais, porque, se estendem a todas as pessoas, sem invocar diferenças de regimes políticos, sociais ou culturais como pretexto para violá-los ${ }^{140}$.

Já Idéia de que os Direitos Humanos passam por uma dimensão jusnaturalista, vem de LOCKE. Para ele, o verdadeiro estado do homem não é o estado civil, mas o natural, ou seja, o estado da natureza onde os homens são considerados

\footnotetext{
${ }^{138}$ LAFER, Celso. A reconstrução dos Direitos Humanos - um diálogo com o pensamento de Hannah Arendt. São Paulo: Companhia das Letras, 1998, ( p.150).

${ }^{139}$ CANOTILHO, José Joaquim Gomes. Direito Constitucional e Teoria da Constituição. $9^{\text {a }}$ edição, Coimbra: Almedina, 2003, (p.325).

${ }^{140} \mathrm{O}$ termo universalidade aparece no artigo $5^{\circ}$ da Declaração de Viena (1993): "todos os direitos humanos são universais, interdependentes e inter-relacionados. A comunidade internacional deve tratar todos os direitos humanos globalmente de forma justa e equitativa, em pé de igualdade e com a mesma ênfase". Logo, a Declaração assinada por 171 Estados, reza pela universalidade e indivisibilidade dos direitos humanos.
} 
livres e iguais. Logo, os Direitos Humanos seriam naturais, porque respeitam a natureza humana e a ela estariam intrínsecos.

LAFER $^{141}$ diz que, para BOBBIO, o jusnaturalismo não possui um atributo de eficácia e não garante nem a paz o a segurança. Ele entende que o Direito para BOBBIO é uma construção, fruto da política que produz o direito positivo que requer a razão para pensar, projetar e ir transformando esse artefato em função das necessidades da convivência coletiva.

Além da teoria do jusnaturalismo, o juspositivismo - positivismo jurídico é defendido por muitos autores, que entendem que o direito é elaborado pelos homens através da norma. Norberto BOBBIO cita a frase de HOBBES, para justificar sua afirmação, dizendo que "não é a sabedoria, mas a autoridade que cria a lei $i^{142 ~ " . ~}$

O positivismo jurídico é uma concepção técnica do direito. A escola positivista define o direito como um conjunto de comandos emanados pelo poder, e desses atos, obtêm-se a eficácia e a validade do direito ${ }^{143}$.

Os Direitos Humanos são classificados como direitos de primeira, segunda, terceira e quarta geração. Esta classificação se deve a uma simples ordem cronológica e metodológica para que se possibilite compreender o contexto histórico em que foram gerados. Para ilustrar essa ordem cronológica, é interessante destacar como surgiu a idéia da "teoria das gerações dos direitos." Um jurista tcheco, naturalizado

\footnotetext{
${ }^{141}$ LAFER, Celso. Apud: BOBBIO, Norberto. A Era dos Direitos. $5^{\text {a }}$ edição, Rio de Janeiro: Campus/Elsevier, 2004.

${ }^{142}$ BOBBIO, Norberto. II positivismo giurídico. Torino, G. Giappichelli, 1979, (p.30).

${ }^{143}$ Segundo o professor Claudio Lembo em seu livro: A Pessoa. Seus Direitos. São Paulo: Manole, 2007, (p.14), acrescenta que os direitos fundamentais encontram melhor abrigo no interior do jusnaturalismo que, por conter valores morais, coloca a pessoa e seus atributos como centrais, e por isso, merece respeito do Estado, que sob nenhum argumento pode agredir a vida, a integridade física, a dignidade da pessoa, ou mais abrangentemente, os próprios Direitos Humanos.
} 
francês, chamado KAREL VASAK, desenvolveu a idéia ${ }^{144}$. Essa teoria, obteve fama internacional e tem sido repetida e discutida por juristas e pesquisadores de todo o mundo.

Os direitos de primeira geração correspondem aos direitos civis (direito à vida, à integridade física e moral, à dignidade, à justiça, à liberdade e à igualdade, à liberdade de pensamento, à consciência, à religião, à opinião e a expressão). Aqui, também se incluem os direitos políticos (direito de participar de movimentos políticos, de votar e ser votado). Esses direitos de primeira geração representam a reafirmação do direito à liberdade em oposição à ação do Estado. São direitos civis e políticos que abrangem o direito à vida e a nacionalidade, a liberdade de ir e vir, o direito ao asilo, a não tortura ou tratamento cruel, desumano ou degradante, a proibição da escravidão, a liberdade de opinião política, entre outros.

Os direitos de segunda geração são os direitos econômicos (direito à propriedade individual e coletiva e à seguridade econômica) e direitos sociais (direito ao alimento, ao trabalho, à seguridade social, ao descanso, à greve, à saúde, à moradia e à educação). Nesse imenso feixe, ainda estão incluídos os direitos culturais (direito de participar de atividades culturais, de beneficiar-se com a ciência, a tecnologia e a investigação científica). Nos direitos de segunda geração o enfoque está nos direitos

\footnotetext{
${ }^{144}$ MARMELSTEIN, George. Curso de Direitos Fundamentais. São Paulo: Atlas, 2008, (p.40). Diz que: "A teoria das gerações, surgiu por acaso. Por volta do ano de 1979, Vasak havia sido convidado para ministrar uma aula inaugural no Curso internacional dos Direitos do Homem, em Estraburgo. Sem muito tempo para preparar uma exposição, ele lembrou da bandeira francesa: liberdade, igualdade e fraternidade. Com base nisso, e sem maiores pretensões, desenvolveu a referida teoria, buscando, metaforicamente, demonstrar a evolução dos direitos fundamentais. Quem narrou essa curiosa história foi o professor Antonio Augusto Cançado Trindade, membro da Corte Internacional de Direitos Humanos, sediada em San josé da Costa Rica”. Ao formular sua teoria inspirado na Revolução Francesa, VASAK disse mais ou menos assim: a primeira geração dos direitos seria a dos direitos civis e políticos, fundamentados na liberdade (liberté) que tiveram origem com as revoluções burguesas; a segunda geração, seria a dos direitos econômicos, sociais e culturais baseados na igualdade (égalité), impulsionada pela Revolução industrial e pelos problemas sociais causados; e a terceira geração seria a dos direitos de solidariedade, em especial o direito ao desenvolvimento, à paz e ao meio ambiente, coroando a tríade com a fraternidade (fraternité), ganhando força após a $2^{\mathrm{a}}$ guerra mundial, e após a Declaração Universal dos Direitos Humanos de 1948.
} 
econômicos, sociais e culturais, que só podem ser desfrutados com o auxilio do Estado, pois ele é que proporcionará o trabalho justo, a possibilidade de pertencer a um sindicato, o direito à educação, à cultura e a seguridade social.

Os direitos de terceira geração são os direitos de solidariedade (direito a paz, ao desenvolvimento econômico, a livre determinação dos povos, ao meio ambiente saudável, ao patrimônio cultural, direitos do consumidor, da infância e dos anciãos). Além do direito ao meio ambiente sadio, os direitos de terceira geração mencionam o direito à paz, ao desenvolvimento, que são desfrutados de forma coletiva, ou seja, pelo indivíduo, pelo Estado e pelas entidades públicas e privadas.

Os direitos de quarta geração tem gerado uma imensa discussão doutrinária. Entre eles, está o direito ao acesso aos meios de comunicação mais modernos como a internet, e consequentemente, a inserção do homem na sociedade tecnológica e na sociedade da informação. A Declaração Universal dos Direitos Humanos de 1948 em seu artigo 19, diz que "Todo o indivíduo tem direito à liberdade de opinião e de expressão, o que implica o direito de não ser inquietado pelas suas opiniões e o de procurar, receber e difundir, sem consideração de fronteiras, informações e idéias por qualquer meio de expressão". Dentro disso, acredita-se que o acesso à informação deva ser considerado como um Direito Humano de quarta geração, pois, todas as pessoas devem ter o direito de acessar esses meios capazes de democratizar a comunicação, com a liberdade para investigar, difundir e expor suas idéias. Somente dessa forma, é possível resolver os problemas cotidianos e garantir uma melhor qualidade de vida, pois o acesso à informação é capaz de melhorar a capacidade do sujeito de intervir na sociedade, buscando formas de exercer sua cidadania e assim, garantir os seus direitos. 


\subsubsection{A Responsabilidade Social Empresarial}

Após esse breve ensaio sobre os Direitos Humanos, que constituem a base fundamental para o exercício dos demais direitos inerentes à dignidade do trabalhador, abordaremos questões relativas à responsabilidade social das empresas e, em especial, com a intenção de verificar como se dá a proteção e a efetivação dos Direitos Humanos no ambiente de trabalho.

Na apresentação da obra "Gestão de Mudança ${ }^{145 ", ~ B A U E R ~ d e s c r e v e ~ u m ~}$ episódio do desenho animado Os Simpsons, em que Homer o pai, acreditando que iria morrer, chama seu filho Bart, para que ouvisse suas últimas palavras e que elas servissem para transmitir a ele algo de sua sabedoria, dissendo: "Já tava assim quando eu cheguei...". Ele refere-se ao mundo, tentando se desculpar pelo caos instalado. Nesse sentido, o autor diz, que a idéia que nós temos de que as coisas são do jeito que são, é, de fato, mais poderosa do que podemos imaginar. Estamos pouco receptivos às mudanças, sejam elas no setor econômico, social, político ou cultural. E essa é uma das características da sociedade ocidental. A situação no mundo dos negócios ainda é mais grave, pois, muitas vezes as mudanças não ocorrem positivamente, porque as pessoas crêem que nada do que fizerem vai mudar o status quo. Porém, os impactos hoje, são globais, e qualquer transformação significativa em algum setor da vida humana, interfere no conjunto da sociedade universal. Estamos todos condenados às mudanças, e mudar para melhor, especialmente no mundo corporativo, pode criar uma onda de satisfação que resultaria em melhores condições de trabalho universais para todos.

\footnotetext{
${ }^{145}$ BAUER, Ruben. Gestão da Mudança - caos e complexidade nas organizações. São Paulo: Atlas, 1999.
} 
DRUCKER $^{146}$, considerado o pai da gestão moderna e reconhecido como um dos principais pensadores dos efeitos da globalização na economia e, em particular, nas Organizações, vai mais além e sugere que se ensine aos executivos, noções e idéias sobre como influir positivamente no curso dos acontecimentos. O importante para o pesquisador é "fazer o futuro". Em um de seus livros, ele trata de assuntos como: direitos humanos, sociedade civil, organizações sem fins lucrativos e responsabilidade social - temas esses, muitas vezes alheios ao mundo dos negócios.

No entanto, estabelecer a relação entre Direitos Humanos, empresa e mundo corporativo, há pouco tempo atrás, era impensável. Até então, os Direitos Humanos eram discutidos na esfera dos Estados e não na esfera do privado. Atualmente, relacionar empresa com Direitos Humanos é um paradigma novo, em que a empresa deve levar em consideração na sua estratégia de gestão respeitando as normas internacionais de Direitos Humanos. É nesse processo, que surge a concepção de empresa socialmente responsável.

As empresas, sejam elas multinacionais ou empresas comerciais que operam em diversos países, enfrentam desafios constantes em vários aspectos. As novas tecnologias, a globalização dos mercados, as pressões sindicais, a qualidade de vida no trabalho, as novas legislações sobre intercâmbios comerciais, a gestão de qualidade e as novas estratégias são exigências constantes que elas precisam observar para se adaptarem ao mercado mundial. Para GIDDENS ${ }^{147}$, a globalização é uma das

\footnotetext{
${ }^{146}$ DRUCKER, Peter Ferdinand. Administrando em Tempo de Grandes Mudanças. Tradução: Nivaldo Montingelli Jr. São Paulo: Pioneira, 1995. O livro aborda o trabalho do executivo e as mudanças que colocam em questão as hipóteses e práticas que até hoje eram dadas como certas. Analisa as implicações da emergência da informação como um recurso primordial do executivo e da organização. Analisa também a economia mundial, em que existem novos centros de poder, novos mercados e novas indústrias em crescimento. Descreve as mudanças ocorridas na sociedade e no governo e os sucessos e fracassos deste na solução dos problemas sociais da nossa época.

${ }^{147}$ GIDDENS. Anthony. Apud: DIAS SOBRINHO, José. Avaliação da Educação Superior. Petrópolis, RJ: Vozes, 2000, (p.28).
} 
características básicas do mundo de hoje e se constitui em um processo em que as modalidades de conexão entre diferentes regiões ou contextos sociais, acabam se enredando por toda a superfície da terra. Ele diz que , "A globalização pode assim ser definida como a intensificação das relações sociais em escala mundial, que ligam localidades distantes de tal maneira que acontecimentos locais são modelados por eventos ocorrendo a muitas milhas de distância e vice-versa”.

Com base nisso, a globalização, traz a necessidade das empresas se adaptarem a um novo contexto, tendo responsabilidades com a vida das pessoas e com o meio ambiente. Por isso, elas não devem permanecer alheias a esse fato. CORTINA ${ }^{148}$, acrescenta que,

La preocupación por la viabilidad de las empresas en la nueva era, que requiere el ejercicio de la prudencia, una prudencia que exige construir y generar confianza; la posibilidad de edificar una ciudadanía cosmopolita con ayuda de las tecnologías de la información, que exige ejercitar la justicia; y la necesidad de asumir la responsabilidad corporativa en el proceso de globalización, recurriendo a la ética de la empresa como o factor de innovación humanizadora.

Nesse escopo, FERNÁNDEZ PEREIRA ${ }^{149}$, diz que a inovação humanizadora na qual a autora se refere, menciona que a empresa deve desenvolver em seu planejamento de gestão e na sua agenda de segurança humana, temas como o respeito a saúde e a segurança do trabalhador, a proteção ao meio ambiente, a eliminação da corrupção e do suborno, a segurança e a qualidade de seus produtos e a contribuição e o respeito aos Direitos Humanos nas comunidades onde opera.

\footnotetext{
${ }^{148}$ CORTINA. A. Apud: FERNÁNDEZ PEREIRA, Juan Pablo. La Seguridad Humana - Un Derecho Emergente. Barcelona: Ariel, 2006, (p.222).

${ }^{149}$ FERNÁNDEZ PEREIRA, Juan Pablo. La Seguridad Humana - Un Derecho Emergente. Barcelona: Ariel, 2006.
} 
O setor privado tem debatido a respeito da responsabilidade social em matéria de Direitos Humanos, principalmente no que se refere ao meio ambiente. Esse desenvolvimento em torno da responsabilidade social das empresas é um marco na busca de alternativas à globalização econômica, tornando-se política comum na estratégia das grandes empresas. Trata-se de um papel de crescente importância, que a empresa vem assumindo no mundo moderno, transformando-se, assim em uma das principais agências de mediação entre o homem e a comunidade.

Atualmente com a existência de um mercado de trabalho global, entender as ligações entre os negócios, o meio ambiente e a sociedade, tornou-se fundamental. Com isso, as empresas compreenderam que necessitavam de ferramentas de administração e gestão que ajudassem a agregar interesses sociais em suas agendas. Em uma entrevista concedida para a Revista Fae Business ${ }^{150}$, Emerson KAPAZ, disse que a responsabilidade social nas empresas representa uma visão empreendedora mais preocupada com o entorno social em que a empresa está inserida, ou seja a empresa não deixa de se preocupar com a necessidade de geração de lucro, coloca-a, não como um fim em si mesmo, mas como um meio para se atingir um desenvolvimento sustentável com mais qualidade de vida.

No Guía Práctica de Derechos Humanos para Empresas ${ }^{151}$, elaborado por María Prandi e José Lozano e editado pela Escuela de Cultura de Paz e pela ESADE, expressa que não se pode levar a cabo uma política de responsabilidade social válida, sem considerar-se a dimensão dos Direitos Humanos. Sendo assim, as empresas não podem permanecer alheias às circunstâncias em que desenvolvem suas atividades e

\footnotetext{
${ }^{150}$ Revista Fae Business, $n^{\circ}$ 9, setembro de 2004. Emerson kapaz do Instituto Ethos. Disponível em: $\langle$ http://www.fae.edu/publicacoes/pdf/revista_fae_business/n9/01_rs.pdf $>$.

${ }^{151}$ Disponível em:http://escolapau.uab.cat/castellano/programas/empresadh.php>. Acesso em 01.03.2009.
} 
devem estar sensíveis às questões relacionadas aos Direitos Humanos, por razões éticas e, também, por questões ligadas à sua própria reputação e competitividade.

Nesse diapasão, a responsabilidade social corporativa ou empresarial, consiste na preocupação que as empresas devem ter com as implicações das suas práticas de negócios que envolvem o meio ambiente. A empresa considerada responsável é aquela que visa, em sua estratégia de gestão, a proteção ao meio ambiente e ao ambiente onde está inserida, através de negócios economicamente viáveis e culturalmente aceitos. De acordo com a Business for Social Responsibility ${ }^{152}$, a expressão responsabilidade social corporativa se refere, de forma ampla, as decisões de negócios tomadas com base em valores éticos que incorporam as dimensões legais, o respeito pelas pessoas, pela comunidade e pelo meio ambiente.

Na década de 50 já alguns países discutiram o tema da responsabilidade social. No Brasil, o debate iniciou-se somente na década de 60 e a visão sobre o papel social das empresas foi baseado principalmente na filantropia. Segundo o Instituto Observatório Social muitas iniciativas sociais de pequenas e médias empresas brasileiras, tinham e ainda têm um caráter filantrópico e paternalista, o que se justificaria pelo quadro de miséria, fome, desemprego, falta de direitos garantidos, corrupção, não cumprimento da legislação vigente, entre outros. Dessa maneira, a responsabilidade social no Brasil, foi inicialmente foi tratada com bases na filantropia. No início da década de 1990, o debate em torno da responsabilidade social e ambiental das empresas, começou a ser discutido de maneira mais consistente. Em 1992, na cidade

\footnotetext{
${ }^{152}$ A Business for Social Responsability - BSR, sediada nos EUA, é a principal entidade mundial na área de CRS (Corporate Social Responsibility). Reúne cerca de 1.600 empresas que representam um faturamento total de cerca de 2 trilhões de dólares, empregando mais de 6 bilhões de trabalhadores em todo o mundo. A BSR é parceira de várias instituições na Europa e América, inclusive do Instituto Ethos de empresas e Responsabilidade Social do Brasil. Ver mais em: http://www.bsr.org/. Acesso em 02.03.2009.
} 
do Rio de Janeiro, foi realizada a Conferência das Nações Unidas sobre Meio Ambiente e Desenvolvimento que reuniu chefes de Estados e representantes oficiais de 179 países. A Agenda $21^{153}$, Documento que resultou dessa Conferência, selou um compromisso entre os países participantes em seguí-la, com o objetivo de promocionar ações que estimulassem a integração entre o crescimento econômico, a justiça social e a proteção ao meio ambiente. Ela é um guia para a implementação de um modelo sustentável de utilização de recursos naturais e preservação da biodiversidade. Os capítulos 29 e 30 do Documento, abordam o papel dos sindicatos, dos trabalhadores e das empresas na execução da Agenda. Segundo ela, o sindicato tem um papel importante e deve ser ativo em relação às atividades que envolvam o desenvolvimento sustentável das Organizações internacionais, nacionais e regionais, dentro do sistema das Nações Unidas.

Já na Europa, o Conselho Europeu de Lisboa ${ }^{154}$, celebrado em março de 2000, chamou as empresas para a Responsabilidade Social em relação aos desafios Europeus do emprego e desenvolvimento econômico sustentável. A partir de então, a União Européia vem demonstrando vários progressos em relação a responsabilidade social de suas empresas e, para isso, elaborou o Documento intitulado "Livro Verde: promover um quadro europeu para a responsabilidade social das empresas ${ }^{155, ",}$ publicado em julho de 2001 pela Comissão das Comunidades Européias. O objetivo do Livro Verde é favorecer um debate na Europa sobre as relações das empresas com a

\footnotetext{
${ }^{153}$ A Agenda 21 Global constitui a mais abrangente tentativa já realizada de promover, em escala planetária, um novo padrão de desenvolvimento, denominado "desenvolvimento sustentável". Após encontros entre 26 Estados na cidade de Brasília (DF), capital brasileira, concluiu-se em 2002, a primeira etapa de elaboração da Agenda 21 brasileira. Atualmente está em curso a segunda etapa, a implementação das políticas públicas propostas. A agenda 21 brasileira foi construída com base na análise das potencialidades do país, nas fragilidades reconhecidas historicamente no processo de desenvolvimento. Não é um plano de governo, mas um compromisso com a sociedade. O governo brasileiro incorporou a Agenda 21 brasileira no Plano Plurianual 2004-2007, instrumento que estabeleceu as diretrizes, os objetivos e as metas da administração pública para operar despesas e programas de duração continuadas. ${ }^{154}$ Conselho Europeu de Lisboa (2000): Conselho Europeu de Lisboa. Comissão Européia de Lisboa.

${ }^{155} \mathrm{O}$ objetivo do documento é lançar um amplo debate quanto às formas de promoção pela União Européia da responsabilidade social das empresas tanto a nível europeu como internacional, incentivando o desenvolvimento de práticas inovadoras, aumentando a transparência, bem como a fiabilidade da avaliação e da validação. Disponível em: <http://europa.eu/index_pt.htm>. Acesso em 29.12.2009.
} 
sociedade, descrevendo os itens que deveriam constar como prioridades da empresa: as demandas dos consumidores, dos trabalhadores, dos inversores e da opinião pública. Ainda, destacam-se no Documento, uma das dimensões da responsabilidade social estritamente ligada aos Direitos Humanos, sobretudo, porque diz respeito às atividades internacionais, reconhecidas nos instrumentos internacionais. Acrescenta que, os Direitos Humanos envolvem questões complexas, inseridas nas esferas política, jurídica e ética. Portanto, sugere que as questões a serem debatidas no âmbito empresarial devem ser as de assegurar de que seus sócios comerciais estão respeitando valores fundamentais; de verificar qual é o enfoque que devem adotar; de estabelecer critérios para trabalhar nos países onde frequentemente há violações dos Direitos Humanos e, finalizando, revela que a União Européia tem a obrigação no marco de sua política de cooperação de garantir o respeito às normas trabalhistas, à proteção ao meio ambiente e aos Direitos Humanos.

O debate sobre o tema está voltado para o comportamento social, trabalhista e ambiental das grandes empresas, principalmente das multinacionais, porque, são consideradas as principais responsáveis pelo crescimento econômico global. As principais referências sobre o tema, tanto no Brasil como na Europa, são o Pacto Global (2000), a Declaração Tripartite da OIT sobre as Multinacionais e a Política Social (1977, 1ª edição), os Princípios e Direitos Fundamentais do Trabalhador (1998), as Diretrizes para Empresas Multinacionais da OCDE (2000). No Brasil, ainda há destaque para a Declaração do Rio e a Agenda 21 da ONU.

O Instituto Ethos do Brasil ${ }^{156}$ elaborou os "Indicadores Ethos de Responsabilidade Social Empresarial”. O objetivo principal dessa ferramenta é auxiliar

\footnotetext{
${ }^{156}$ O Instituto Ethos do Brasil foi criado em 1998 por um grupo de empresários e executivos oriundos da iniciativa privada. É uma organização sem fins lucrativos, caracterizada como Oscip (organização da
} 
as empresas a gerenciarem os impactos sociais e ambientais provenientes das suas atividades. É um instrumento de auto-avaliação que sugere parâmetros de políticas e ações que a empresa pode desenvolver para aprimorar seu comprometimento com a responsabilidade social. Os principais índices tratados atualmente, em relação ao tema, são:

- Os valores, a transparência e a governança (auto regulação da conduta e relação transparente com a sociedade);

- $\quad$ o público interno (diálogo e participação, respeito ao indivíduo e trabalho decente);

- $\quad$ O meio ambiente (responsabilidade com as gerações futuras e gerenciamento do impacto ambiental);

- Os fornecedores (seleção, avaliação e parcerias com fornecedores);

- $\quad$ Os consumidores e clientes (dimensão social do consumo);

- $\quad$ A comunidade (relações com a comunidade local e ação social);

- O governo e sociedade (transparência e política e liderança social) ${ }^{157}$.

A partir desse cenário, uma empresa socialmente responsável é aquela que compromete-se publicamente a seguir as normas internacionais e envolve as partes interessadas no acompanhamento das suas práticas, estabelecendo relações saudáveis com os stakeholders, levando em conta, seus interesses por meios de mecanismos de

sociedade civil de interesse público). Sua missão é mobilizar, sensibilizar e ajudar as empresas a gerir seus negócios de forma socialmente responsável, tornando-as parceiras na construção de uma sociedade justa e sustentável. Fonte: 〈http://www.ethos.org.br〉. Acesso em 29.12.2009.

${ }^{157}$ No que respeita ao indicador trabalho decente, o Instituto enfatiza a política de remuneração, os benefícios e a carreira, os cuidados com a saúde, a segurança e as condições de trabalho, o compromisso com o desenvolvimento profissional e a empregabilidade, o comportamento nas demissões e a preparação para aposentadoria. Fonte: Indicadores Ethos de Responsabilidade Social Empresarial (versão 2009). 
consulta e participação, desenvolvendo seus negócios de forma a beneficiar a todos, inclusive os grupos que compõem a cadeia produtiva, procurando gerar emprego estável, contribuindo para a justa distribuição das riquezas e reduzindo a exclusão de grandes grupos. Entende-se também que as empresas responsáveis devem contribuir para o desenvolvimento da sociedade que fazem parte, fortalecendo suas estruturas democráticas de participação, inovando na redução dos impactos ambientais nãodesejados e atuando proativamente em relação à incorporação das expectativas da sociedade $^{158}$. Porém, essas premissas estão pouco presentes no cenário empresarial e o número de empresas que exercem uma cultura de responsabilidade social ainda é muito pequena, principalmente no que refere ao respeito aos Direitos Humanos do trabalhador.

Dentro disso e conforme a dicussão teórica proposta no capítulo I sobre os direitos fundamentais e a dignidade do trabalhador, iremos analisar alguns intrumentos internacionais e iniciativas da sociedade civil que integram o debate sobre a responsabilidade das empresas em atuarem na proteção dos Direitos Humanos dos trabalhadores. Essas iniciativas, tem como base, o Direito Internacional e estão pautadas em Diretrizes e Normas e, para tanto, antes de começarmos a citá-las vamos discorrer sobre alguns conceitos de Direito Internacional, fundamentais à compreensão das referidas Regras.

Entende-se por Direito Internacional o conjunto de normas que regulam as relações externas dos atores que compõem a sociedade internacional. Esses atores são chamados de "sujeitos de direito internacional", que são os Estados nacionais, embora na prática, a doutrina reconheça outros atores como as Organizações internacionais. A Organização internacional é uma associação voluntária de sujeitos de Direito

\footnotetext{
${ }^{158}$ Fonte: Observatório Social... Op. Cit. Nota 18, (p.23).
} 
Internacional (quase sempre Estados), constituída mediante um ato internacional (geralmente um Tratado), de caráter relativamente permanente, dotada de regulamento e de órgãos de direção próprios, cuja finalidade é atingir os objetivos comuns determinados por seus membros constituintes. Nos termos de seus atos constitutivos, as Organizações internacionais possuem o direito de delegação, podendo manter relações diplomáticas com outros sujeitos de Direito Internacional. Em Direito Internacional, o termo Organização internacional aplica-se apenas às Organizações constituídas por Estados, e não as chamadas organizações não-governamentais, formadas pela sociedade civil e que podem, eventualmente, ter interesses na atuação internacional.

O Direito Internacional atingiu seu pleno desenvolvimento no século XX. Com a criação da Comissão de Direito Internacional das Nações Unidas em 1947, o Direito Internacional entrou em uma nova fase, passando a ser mais eficaz e preoupação de muitos Estados, pois, é um meio para manter a paz e a ordem mundial. A partir de 1958 na cidade de Genebra, importantes Convenções foram firmadas, nesse sentido. Dentre elas, destacamos a de Relações Diplomáticas (1961), a de Relações Consulares (1963), a dos Direitos dos Tratados (1969), a de Representação dos Estados em suas Relações com Organizações Internacionais de Caráter Universal (1975), a de Sucessão de Estados em matéria de Tratados (1978), a de Sucessão de Estados em matéria de Bens, Arquivos e Dívidas Estatais (1983) e a que versa sobre o Direito dos Tratados entre Estado e Organizações Internacionais ou Organizações internacionais (1985).

A partir de então, o Direito Internacional teve uma ampliação em seu âmbito de atuação e, hoje em dia, as questões que envolvem direitos e liberdades fundamentais da pessoa, como o terrorismo, a proteção ao meio ambiente, o tráfico de 
pessoas e o desrespeito a liberdade de expressão, encontram-se previstas nos

Documentos internacionais, representando que os Estados membros estão concordes com suas regras pactadas.

Com a globalização mundial, os espaços regionais ficaram economicamente integrados e a interdependência das economias, cada vez menos nacionais, marcam a relevância do Direito Internacional. Assim, uma das principais fontes do Direito Internacional, passa a ser a Convenção de Viena sobre o direito dos tratados, assinada em 1969, que foi complementada por outra Convenção de 1986 sobre o direito dos tratados entre Estados e Organizações internacionais ou Organizações internacionais, com o objetivo de reconhecer o direito das Organizações de firmarem Tratados e Convenções. É importante dizer que, tratado é o ato jurídico por meio do qual se manifesta o acordo de vontades entre duas ou mais pessoas internacionais ${ }^{159}$.

O direito define Tratado de modo uniforme. A Convenção sobre o direito dos tratados, determina em seu artigo $2^{\circ}$, paragrafo $1^{\circ}$ que, "Tratado significa um acordo internacional celebrado entre Estados em forma escrita e regido pelo direito internacional, que conste, ou de um instrumento único ou de dois ou mais instrumentos conexos, qualquer que seja sua denominação específica". Os tratados internacionais, enquanto acordos internacionais juridicamente obrigatórios e vinculantes, constituem a principal fonte de obrigação do Direito Internacional. O termo "tratado" é um termo

\footnotetext{
${ }^{159}$ Segundo os autores G.E do Nascimento e Silva e Hildebrando Accioly no trabalho publicado em 2002, Manual de Direito Internacional Público, apontam que: "da terminologia tratado, referindo-se a um acordo regido pelo direito internacional, "qualquer que seja a sua denominação". Em outras palavras, tratado é a expressão genérica. São inúmeras as denominações utilizadas conforme a sua forma, seu conteúdo, o seu objeto ou o seu fim, citando-se as seguintes: convenção, protocolo, convênio, declaração, modus vivendi, ajuste, compromisso etc, além das concordatas, que são os atos sobre assuntos religiosos celebrados pela Santa Sé com os Estados que tem cidadãos católicos. Hoje em dia, o tipo de tratado hierarquicamente mais importante é a Carta, expressão utilizada no tocante às Nações Unidas e à Organização dos Estados Americanos. Apalavra Estatuto, outrora sem maior expressão, é a que se nos depara em relação à Corte Internacional de Justiça. A palavra convenção tem sido utilizada nos principais tratados multilaterais, como os de codificação assinados, dentre outros, em Viena ou na Haia".
} 
genérico, usado para incluir as Convenções, os Pactos, as Cartas e demais acordos internacionais ${ }^{160}$. Considerando esse conceito, afirmamos que, quando os Estados ou as Organizações assinam um tratado e tem, esse acordo de reciprocidade, ele passa a ser fonte do Direito Internacional.

Nesse contexto, vale salientar que o homem possui certos direitos primordiais inerentes à sua personalidade e que o Direito Internacional já reconhece e garante. Dentro disso, que a Carta das Nações Unidas, insistiu na existência desses direitos e liberdades fundamentais e a Declaração Universal dos Direitos do Homem definiu esses direitos ${ }^{161}$.

Acreditamos que a globalização econômica tem trazido novos caminhos para o Direito Internacional dos Direitos Humanos. Entretanto, a existência das violações desses direitos são cada vez maiores. Por isso, o desafio que se instala, é o de proporcionar instrumentos para garantir a proteção da pessoa humana do trabalhador. As iniciativas e as estratégias de gestão que as empresas utilizam, estão centradas em referências básicas da OCDE, da OIT e da ONU, que veremos a partir de agora.

\subsection{As Diretrizes para as Empresas Multinacionais da Organização} para Cooperação e Desenvolvimento Econômico (OCDE)

Após a segunda guerra mundial em 1947 foi criada a Organização para a Cooperação Econômica Européia, e o objetivo era buscar a ajuda Canadense e Norte Americana para a reconstrução da Europa, sob o Plano Marshall. Em 1961 ela foi

\footnotetext{
${ }^{160}$ GOMES, Luiz Flávio e PIOVESAN, Flávia. O Sistema Interamericano de Proteção dos Direitos Humanos e o Direito Brasileiro. São Paulo: RT, 2000, (p.155).

${ }^{161} \mathrm{O}$ direito à liberdade individual do homem e à proteção de sua pessoa estão proclamados no art. $1^{\circ} \mathrm{da}$ Declaração Americana dos Direitos e Deveres do Homem: "Todo ser humano tem direito à vida, à liberdade e a segurança de sua pessoa." e no art. $3^{\circ}$ da Declaração Universal dos Direitos do Homem: "Todo o indivíduo tem direito à vida, à liberdade e à segurança pessoal."
} 
substituida pela Organização para a Cooperação e Desenvolvimento Econômico, a OCDE, integrada atualmente por 30 países com direito a voto, incluida a Espanha, sendo o Brasil um membro observador ${ }^{162}$. A missão da OCDE é apoiar o crescimento econômico sustentável, impulsionar o emprego, elevar o nível de vida, manter a estabilidade financeira, contribuir para o desenvolvimento nos países industrializados e aqueles em vias de desenvolvimento e contribuir para o crescimento do comércio mundial. Em 1976 a OCDE elaborou a Guidelines for Multinational Enterprises Diretrizes para as Empresas Multinacionais que, a partir de 1992 passaram por uma revisão a fim de adequá-las ao novo contexto econômico e, em 1999, os países membros concordaram em incluir normas trabalhistas no Documento. Só então, em 2000, foi concluída a nova versão das Diretrizes, envolvendo Organizações nãogovernamentais, Parceiros Sociais ${ }^{163}$ e países não membros, como é o caso do Brasil $^{164}$.

Nas palavras de MARTÍN ORTEGA o preâmbulo das linhas Diretrizes da OCDE “anuncia lo que va a ser uno de los elementos más importantes introducidos por la revisión: la incersión de la recomendación explícita de las empresas

\footnotetext{
${ }^{162}$ Os Estados membros da OCDE são: Austrália, Áustria, Alemanha, Bélgica, Canadá, Coréia do Sul, Dinamarca, Eslováquia, Espanha, Estados Unidos, Finlândia, França, Grã-Bretanha, Grécia, Holanda, Hungria, Islândia, Irlanda, Itália, Japão, Luxemburgo, México, Nova Zelândia, Noruega, Polônia, Portugal, República Tcheca, Suécia, Suíça e Turquia.

${ }^{163}$ Parceiros sociais da OCDE: O Comitê Consultivo Empresarial (BIAC) e o The Trade Union Advisory Committee - Comitê Consultivo Sindical (TUAC). O TUAC é uma organização sindical internacional não-governamental, atua como órgão consultivo da OCDE, sua fundação ocorreu em 1948 como comitê de defesa sindical para o programa de recuperação econômica da Europa (Plano Marshall). Esse sindicato reúne 55 centrais sindicais nacionais, representado nos países membros da OCDE. O objetivo maior da organização é de assegurar que as políticas econômicas dirigidas ao crescimento objetivem o pleno emprego e a melhoria do bem estar social, resguardando o interesse dos trabalhadores. Publicações e documentos do TUAC podem ser encontrados no site: 〈http://www.tuac.org >.

${ }^{164}$ Mesmo sendo não-membro, o país tem estabelecido um ponto de contato nacional com a finalidade de promover e zelar pela efetiva implementação e divulgação das diretrizes da OCDE para empresas multinacionais. O Ponto de Contato Nacional, é geralmente um funcionário do governo federal indicado pelo país aderente à Declaração. Esse contato é responsável por encorajar a observância das Diretrizes no contexto nacional e garantir que elas sejam conhecidas e entendidas pela comunidade empresarial, as organizações sindicais, outras organizações não governamentais e o público interessado. Disponível em: $<$ http://www.fazenda.gov.br/sain/>. Acesso em 06.01.2010.
} 
multinacionales de respetar los derechos humanos de aquellas personas afectadas en consistencia con las obligaciones y compromisos internacionales de los Estados receptores $^{165, "}$

Um dos princípios das linhas Diretrizes para as Empresas Multinacionais é a tradução de boas práticas recomendáveis à todas as empresas, não fazendo distinção de tratamento entre empresas nacionais e multinacionais, visando promover uma conduta empresarial responsável e consistente. O objetivo das Diretrizes é assegurar que as atividades das empresas estejam em sintonia com as políticas governamentais, estabelecendo uma relação de confiança com a sociedade onde operam. Objetiva também, a melhoria do clima para investimentos estrangeiros, contribuindo para um desenvolvimento sustentável produzido pelas empresas multinacionais.

As linhas Diretrizes envolvem um amplo leque de temas como: meio ambiente; acesso à informação; emprego; interesses dos consumidores; ciência e tecnologia; fisco e corrupção. Segundo suas políticas gerais, as empresas deverão:

a) Contribuir para o progresso econômico, social e ambiental objetivando o desenvolvimento sustentável;

b) Respeitar os Direitos Humanos de todos os envolvidos nas atividades da empresa, conscientes e em sintonia com os compromissos internacionais do governo hóspede;

c) Estimular o fortalecimento das capacidades da comunidade local;

d) Criar oportunidades de empregos e formação profissional;

\footnotetext{
${ }^{165}$ MARTÍN ORTEGA, Olga. Empresas Multinacionales y Derechos Humanos en Derecho Internacional. Barcelona: Bosch Editor, 2008, (p.151).
} 
e) Abster-se de procurar ou aceitar isenções que não constem do quadro estatutário ou regulamentar, em relação ao meio ambiente, à saúde, à segurança, ao trabalho, aos impostos, aos incentivos financeiros ou a outras questões;

f) Respaldar e manter bons princípios de governança corporativa;

g) Desenvolver e aplicar práticas que fomentem uma relação de confiança mútua entre as empresas e as sociedades nas quais realizam suas operações;

h) Divulgar para os trabalhadores as políticas da empresa e estimular que suas ações sejam adequadas a elas;

i) Abster-se de ação discriminatória ou disciplinar contra os empregados que fizerem relatórios sobre as práticas transgredindo a lei, as Linhas Diretrizes ou a política empresarial;

j) Estimular os sócios empresariais, provedores e serviços terceirizados, a aplicarem princípios de conduta empresarial consistentes com as Linhas Diretrizes;

k) Evitar envolvimento abusivo nas atividades políticas locais.

Além das Diretrizes gerais, o Documento aborda outras questões importantes. Uma delas é a respeito da divulgação das informações que as empresas devem fornecer ao público no que se refere ao seu ramo de atividade, endereço, localização, razão social, estrutura, objetivos empresariais, resultados financeiros e correntes da empresa, acionistas majoritários e direito a voto, membros do conselho, sistema de gestão e risco, informações que dizem respeito aos trabalhadores especificamente, como a alteração no processo produtivo ou o fechamento de unidades. Devem informar também, sobre a política de sua gestão e o Código de Conduta ${ }^{166}$.

\footnotetext{
${ }^{166}$ Ver o texto na íntegra: <http://www.fazenda.gov.br/sain/pcnmulti/novo.asp. Acesso em 06.01.2010.
} 
As linhas Diretrizes dedicam um capítulo específico a questão do emprego e das relações empresarias. Nele constam os direitos fundamentais do trabalhador, como o direito a ser representado por um sindicato, a eliminação do trabalho infantil e do trabalho forçado, a proibição de discriminação contra o trabalhador, a implantação de medidas para garantir a saúde e a segurança no trabalho, entre outros.

O não cumprimento das Diretrizes da OCDE traz uma publicidade negativa para empresa, anunciando sua marca à exploração trabalhista e a contaminação ambiental, fazendo com que ela perca negócios. Por isso, a observação dessas Normas, podem nos ajudar a pressionar as empresas que não atuam de maneira social ou ambientalmente responsável, já que, atuar contra elas, poderá prejudicar os negócios dessas empresas associadas, pois o consumidor atual está cada vez mais atento às questões ambientais e sociais, por exemplo.

O procedimento da apresentação de uma reclamação contra uma empresa oferece foro com respaldo governamental. A aplicabilidade das Diretrizes é extraterritorial, já que são aplicados em países membros e signatários da OCDE, portanto, podem ser uma opção onde o marco legal não funciona ou, onde as ONGs não tenham acesso ao sistema legal. As empresas que operam nestes países estão vinculadas pelas Diretrizes e pode-se ordená-las que as cumpram $^{167}$. Nesse sentido, as regras referidas são um instrumento importante para os trabalhadores que possam a vir a ter seus Direitos Humanos violados. As denúncias a respeito de empresas que não respeitam os critérios impostos pelas Diretrizes, só serão analisadas quando outras medidas já foram tomadas pelos sindicatos ou pelos representantes dos trabalhadores,

\footnotetext{
${ }^{167}$ TORRES, Ciro; BEZERRA, Isaías; HERNANDES, Tânia (organizadores). Responsabilidade Social das Empresas Multinacionais. Diretrizes da OCDE. Rio de Janeiro: CERIS/IBASE, 2004, (pp.27-28).
} 
tais como as tentativas de negociação, se acordos, as greves e outras formas de manifestação de descontentamento.

As linhas Diretrizes da OCDE é um dos Documentos mais citados nos Códigos de Conduta empresariais e são apoiadas pelas ONGs e sindicatos. Elas contribuem para que haja conscientização internacional no que respeita a gestão e a responsabilidade das empresas multinacionais. As Regras foram complementadas em 2006 para conscientizar e sensibilizar as empresas sobre os riscos de operarem em zonas de conflito ou em países com "má governança", ou seja, nos países onde ocorrem mais comumente a corrupção, o abuso de poder, a falta de transparência ou a violação dos Direitos Humanos. O Documento publicado pela própria OCDE, intitulado Risk Awareness Tool Multinational Enterprises in Weak Governance Zones, diz que as empresas, no caso as multinacionais, podem evitar a violação dos Direitos Humanos através do cumprimento da lei e da observância dos instrumentos internacionais, levando em conta a política local quando coloca em prática suas atividades, e deve ter o cuidado ao escolher clientes e sócios comerciais naquelas áreas de risco. Aborda dilemas éticos, levantando questões para as empresas refletirem ao atuarem, tais como:

- A empresa é confiante de que, neste ambiente de investimento, será capaz de pôr em prática políticas e processos de negócio que lhe permitirá a obedecer a legislação aplicável e observar os instrumentos internacionais pertinentes, incluindo as orientações da OCDE para Empresas Multinacionais?

- Que medidas a empresa pode tomar para evitar situações que poderiam agravar os problemas existentes (por exemplo, violações dos Direitos Humanos, conflitos violentos, corrupção em empresas estatais)? 
- Que medidas a empresa pode tomar para respeitar os Direitos Humanos daqueles afetados por suas atividades?

- Quais as medidas a empresa pode tomar para avaliar a capacidade do país de acolhimento e vontade de respeitar os Direitos Humanos?

- $\quad$ Como a empresa pretende proteger seus funcionários das ameaças relacionadas aos conflitos violentos, à atividades de extorsão e outras atividades criminosas?

No final do Documento listam-se uma série de iniciativas e nominam-se os documentos internacionais onde as empresas podem obter informações e orientações a respeito da responsabilidade social e da boa gestão ${ }^{168}$.

\subsubsection{A Declaração Tripartite de Princípios sobre Empresas}

\section{Multinacionais e a Política Social da OIT}

A Declaração Tripartite de Princípios sobre Empresas Multinacionais da OIT foi adotada pelo Conselho de Administração da Oficina Internacional do Trabalho em sua 204ª reunião em Genebra em 1977 e revisada em 2000. O Documento é uma recomendação aos governos, às organizações de empregados e empregadores e às empresas multinacionais e a sua adoção tem caráter voluntário, não tendo relação com as obrigações causadas pela ratificação de uma convenção da OIT. O principal objetivo é de promover uma contribuição ativa das empresas multinacionais para o progresso econômico e social, minimizando os efeitos negativos das suas atividades.

\footnotetext{
${ }^{168}$ O Documento foi desenvolvido pelo grupo de trabalho sobre Corrupção em transações comerciais internacionais, da rede de assistência ao desenvolvimento do Comitê sobre Conflitos, Paz e Cooperação para o Desenvolvimento e o Comitê de Gestão Pública da OCDE, contou ainda com a participação do BIAC e TUAC. Documento disponível em inglês: http://www.ocde.org/dataocde/26/21/36885821.pdf. Acesso em 20.03.2010.
} 
De acordo com BONET PEREZ ${ }^{169}$ "la OIT proporciona un marco extraordinario para la regulación de la conducta de las empresas multinacionales, ya que es el foro en el que participan tres de los principales sujetos implicados y por su propia trayectoria como Organización internacional dedicada a la consecución de la justicia social". Nesse trecho do texto, podemos perceber que um dos principais fundamentos da Instituição encontra-se claramente presente: o de que a paz universal e permanente só pode basear-se na justiça social e que é a estrutura internacional que possibilita que se abordem estas questões e a busca soluções que permite a melhoria das condições de trabalho no mundo. Também nesse sentido, MARTÍN ORTEGA diz que a Declaração se dirige aos Estados membros e as entidades privadas que são as empresas. Acrescenta que a contribuição fundamental da Declaração é que ela estabelece o enraizamento do controle da conduta das empresas multinacionais nas normas de Direito Internacional do Trabalho, em particular, e no Direito Internacional em geral ${ }^{170}$.

De acordo com a política social, a Declaração estabelece que todas as partes, devem respeitar os direitos soberanos, observando as normas jurídicas nacionais, tendo em conta as práticas locais e respeitando as normas internacionais aplicáveis. Quanto a essas normas específicas, o Documento sugere àqueles governos que ainda não ratificaram os Convênios números 87, 98, 111, 112, 138 e 182 que procedam as ratificações ou apliquem as medidas possíveis através de suas políticas nacionais, e também as Recomendações números $111,119,122,146$ e $190^{171}$. Portanto, ao contrário a

\footnotetext{
${ }^{169}$ BONET PEREZ, J. Principios y Derechos Fundamentales en el Trabajo. Apud: MARTÍN ORTEGA. Olga. Empresas Multinacionales ...Op. Cit. Nota 165, (p.174).

${ }^{170}$ MARTÍN ORTEGA. Olga. Empresas Multinacionales (...) Op. Cit. Nota 165.

${ }^{171}$ Convênio sobre a liberdade sindical e a proteção ao direito de sindicalizar-se, 1948 (n $\mathbf{8 7}^{\mathbf{0}}$ ); sobre o direito de sindicalização e negociação coletiva, 1949 ( $\mathbf{n}^{\mathbf{0}}$ 98); sobre a discriminação (emprego e

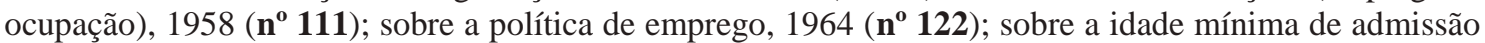
ao emprego, 1973 ( $\mathbf{n}^{\mathbf{0}} \mathbf{1 3 8}$ ); sobre a proibição de todas as formas de trabalho infantil, 1999 ( $\left.\mathbf{n}^{\circ} \mathbf{1 8 2}\right)$. Recomendação sobre a discriminação (emprego e ocupação), 1958 ( $\left.\mathbf{n}^{\mathbf{0}} \mathbf{1 1 1}\right)$; sobre a relação de trabalho, 1963 (n 119); sobre a política de emprego, 1964 ( $\left.\mathbf{n}^{\mathbf{0}} \mathbf{1 2 2}\right)$; sobre a idade mínima, 1973 ( $\left.\mathbf{n}^{\mathbf{0}} \mathbf{1 4 6}\right)$, e a Recomendação sobre as piores formas de trabalho infantil, 1999 (n 190).
} 
Declaração da OCDE, esse Documento não faz referência alguma sobre parâmetros ambientais, se limitando, somente, ao âmbito laboral e social.

Segundo a OIT as empresas multinacionais desempenham um papel muito importante nas economias dos países onde estão inseridas e nas relações econômicas internacionais, tanto para os empregadores, os trabalhadores como para suas respectivas organizações. Mediante as inversões diretas internacionais, as empresas podem aportar vantagens substanciais nos países onde operam e nos países de origem, contribuindo para uma utilização eficaz do capital, da tecnologia e do trabalho, na promoção do bem estar econômico e social, na melhora do nível de vida dos trabalhadores, na criação de oportunidades de emprego e na promoção dos Direitos Humanos básicos em todo o mundo.

As Recomendações em relação aos direitos fundamentais dos trabalhadores são a promoção do emprego, onde os governos devem estimular o crescimento e o desenvolvimento econômico, fomentando as políticas neste sentido. Quanto às empresas, se prevê que elas devem colaborar com essas políticas nos países onde operam, aumentando as oportunidades de emprego e formação profissional em conjunto com os representantes dos trabalhadores e/ou sindicatos. Impulsionar políticas parar a promoção da igualdade de oportunidades e trato no emprego, eliminando todas as formas e discriminação, é outra recomendação importante e que vale a pena ser destacada. Quanto a segurança no emprego e a formação, a Declaração afirma que as empresas devem adotar medidas para assegurar o emprego estável, as instâncias de representação dos trabalhadores devem elaborar políticas nacionais de orientação e formação profissionais voltadas para o emprego Em matéria de segurança e higiene no 
ambiente de trabalho as empresas devem aplicar as normas nacionais que regem essa matéria, incluindo as questões que tem relação com o tema, previstas nos Convênios coletivos em conjunto com os representantes dos trabalhadores. Quanto às relações de trabalho o documento reza que, todo o trabalhador tem direito de sindicalizar-se ou de constituir organizações que acreditar convenientes. É importante lembrar que, o Documento foi revisado e ampliado no ano 2000, porém, não mencionou diretamente a violência ou o assedio nas relações de trabalho.

A Declaração Tripartite da OIT se sustenta nas suas Convenções, e tem caráter de Recomendação. A continuidade e a implementação da Declaração se divide em três partes: a pesquisa realizada sobre o grau de cumprimento da Declaração, o procedimento de interpretação e a análise dessas informações e a promoção do Documento por meio de atividades de investigação e outras ações ${ }^{172}$. Mesmo com tais mecanismos de acompanhamento, denúncia e questionamento, não existe a possibilidade de punição além da moral.

\subsubsection{O Pacto Global (Global Compact) da Organização das Nações}

\section{Unidas para as Empresas}

Diez años después, el Pacto Mundial sigue siendo la mayor iniciativa mundial de sostenibilidad empresarial (...) el Pacto Mundial ha pasado a ser sinónimo de responsabilidad empresarial. Sus miembros han ido mucho más allá de la filantropia. Han sido pioneros en llevar las mejores prácticas hasta nuevos niveles en las esferas de los derechos

\footnotetext{
${ }^{172}$ Os Estados membros, as organizações de empregados e empregadores e as empresas multinacionais devem enviar as informações acerca da implementação da declaração e as estratégias adotadas para a Subcomissão de Empresas Multinacionais (esse procedimento foi desenhado pelo Conselho de Administração, um órgão executivo, que toma decisões a respeito da política da OIT, em 1979). Depois que a subcomissão analisa e interpreta as informações da pesquisa, ela emite recomendações necessárias sobre as ações a empreender. Até o momento foram realizadas 8 pesquisas. $\mathrm{O}$ último informe da subcomissão de empresas multinacionais estão no Doc OIT GB301/12/301 ${ }^{a}$ reunião, Genebra/março de 2008.
} 
humanos y el derecho laboral (...) Han llevado a cabo centenares de proyectos en materia de salud, educación e infraestructura en paises de todo el mundo.

Discurso plenario "El Pacto Mundial y la creación de mercados sostenibles" Foro Económico Mundial. Davos, Jan/2009)

O Pacto Mundial (Global Compact) é uma iniciativa voluntária proposta pelas Nações Unidas, com a finalidade de mobilizar a comunidade empresarial internacional para a adoção, em suas práticas de negócios, dos valores fundamentais e internacionalmente aceitos nas áreas de Direitos Humanos, trabalho, meio ambiente e combate à corrupção. A iniciativa surgiu durante o Fórum Econômico Mundial em Davos, em 1999, a partir da proposta do secretário Kofi Annan. Criada com o objetivo de reflexionar e debater a cultura de responsabilidade social corporativa, não possui estrutura rígida e não é um Código de Conduta obrigatório. É um processo aberto de engajamento, em que as organizações interessadas possam discutir e se informar a respeito das ações práticas e positivas implementadas e não está prevista nenhuma penalização por parte das Nações Unidas para as empresas que não o observarem. Com relação ao Brasil, o Instituto Ethos assumiu a tarefa de promover o Pacto Global, convidando as empresas brasileiras a figurarem entre as primeiras signatárias da Agenda Global Compact, por meio de um evento realizado em 2003. Atualmente, segundo dados encontrados no site oficial do Pacto Global, o Brasil possui 307 entidades signatárias da iniciativa. Na Espanha a "Red Española del Pacto Mundial de Naciones Unidas" conta, neste momento, com 932 firmantes e 231 sócios.

A empresa que tiver interesse em participar da iniciativa, deve ter um compromisso visível com os princípios do Pacto. Ela deverá incorporar os princípios da iniciativa em sua gestão, em sua estratégia, na cultura e no dia a dia da atividade 
empresarial, publicando um informe anual das suas "melhores práticas" e as ações que realiza para implementar o Pacto (Comunicação de Progresso). Ademais, deverá divulgar o apoio que tem com a iniciativa, através dos meios de comunicação. Essa rede engloba cinco agências da ONU: a Oficina do Alto Comissionado para os Direitos Humanos (ACNUR); a Organização Internacional do Trabalho (OIT); o Programa das Nações Unidas para o Meio Ambiente (PNUMA); a Organização das Nações Unidas para o Desenvolvimento Industrial (ONUDI) e o Programa das Nações Unidas para o Desenvolvimento (PNDU). A idéia é realizar um trabalho multidisciplinar nesse sentido, já que a atuação das empresas pode refletir em diversas áreas.

De acordo com o Guía del Pacto Global - Uma forma prática para implementar os nove princípios na gestão empresarial, demonstra que a iniciativa oferece numerosas vantagens para as empresas participantes, porque, permite apoiar a formulação de soluções práticas para os problemas contemporâneos relacionados com a globalização, o desenvolvimento sustentável e a responsabilidade cívica corporativa, dentro de um contexto de interesses múltiplos; a adesão dos princípios universais e a boa cidadania corporativa para lograr que a economia global seja mais sustentável e integrada; colaborar para lograr os objetivos mundiais da ONU e entrar em acordo com os governos, as empresas, a sociedade civil e outras comunidades - pessoas e instituições de interesses. Essas ações permitem compartilhar as boas práticas e as experiências das empresas e facilitar o acesso a um conhecimento mais profundo da missão da ONU em temas relacionados ao desenvolvimento e seu alcance prático em todo o mundo.

Os dez princípios do Pacto Mundial estão baseados em um consenso universal e em quatro instrumentos internacionais: a Declaração Universal dos Direitos 
Humanos (1948); a Declaração Internacional do Trabalho sobre Princípios e Direitos Fundamentais no Trabalho (1998); a Declaração do Rio de Janeiro sobre Meio Ambiente e Desenvolvimento Sustentável (1992) e a Convenção das Nações Unidas contra a Corrupção (2003).

A justificativa da ONU na escolha desses temas consiste na compreensão de que o homem do mundo e dos negócios pode fazer a diferença e o mercado global pode ser afetado pelo não cumprimento desses princípios básicos. Os temas propostos possuem, ainda, um potencial efetivo para influenciar e gerar mudanças positivas no mundo corporativo e nas comunidades onde as empresas que aderirem aos princípios estão localizadas. Ao aderirem o Pacto Global da ONU para as empresas, elas demonstram estar comprometidas com os seguintes princípios:

\section{Sobre os Direitos Humanos}

As empresas signatárias devem apoiar e respeitar a proteção aos Direitos Humanos reconhecidos internacionalmente, como o primeiro princípio do Pacto Global. O segundo princípio, afirma que elas devem assegurar-se em não participar de nenhum tipo de ação que leve a violação desses direitos consagrados internacionalmente. No enunciado sobre os Direitos Humanos, segundo MATÍN ORTEGA ${ }^{173}$, se destacam vários elementos interessantes, “(...) la definición de las obligaciones como apoyar es decir, promover y facilitar, y respetar, es decir, no violar directamente, los derechos humanos y no ser cúmplices, es dicer no participar directamente en dichos abusos (...)" O enunciado se faz claro tanto juridicamente, como moralmente, porque, quem é cúmplice é tão responsável quanto quem realiza o ato contrário a essas Normas fundamentais.

\footnotetext{
${ }^{173}$ MATÍN ORTEGA, Olga, Empresas Multinacionales (...) Op. Cit. Nota 165, (p.194).
} 
A razão da escolha dos Direitos Humanos como o primeiro princípio do Pacto, ocorreu, porque nas últimas décadas, se produziu uma série de acontecimentos lesivos ao ser humano. Dentre eles, destacamos as guerras civis, a discriminação das mulheres, das crianças e dos velhos, atentando contra seus direitos individuais e as mais variadas violações cometidas pelos sistemas de governo totalitários, tais como o genocídio e o terrorismo, a tortura, e o trabalho escravo. Conforme a Anistía Internacional, cerca de dezoito a vinte e sete mil pessoas são condenadas a morte em todo o mundo. No ano de 2007 por exemplo, foram executadas pelo menos mil duzentas e cinquenta e duas pessoas em vinte e quatro países em todo o mundo. E em cinquenta e um países, três mil trezentas e quarenta e sete pessoas foram executadas e condenadas à morte ${ }^{174}$. Essas formas de agressão aos Direitos Humanos, impulsionaram a rediscussão de um catálago de direitos básicos dirigidos às empresas. Após a promulgação pelas Nações Unidas em 1948 da Declaração Universal dos Direitos Humanos, seguiram-se outros Pactos e Documentos internacionais que buscaram assegurar e garantir os direitos mínimos da pessoa. Nesse sentido, PEREZ LUÑO ${ }^{175}$, afirma que,

Los derechos humanos suelen venir entendidos como un conjunto de facultades e instituciones que, en cada momento histórico, concretan las exigencias de la dignidad, la libertad y la igualdad humanas, las cuales deben ser reconocidas positivamente por los ordenamientos jurídicos a nivel nacional e internacional. En tanto que con la noción

\footnotetext{
${ }^{174}$ A Anistia Internacional é um movimento global integrado por 2,2 milhões de pessoas em mais de 150 países e territórios. O movimento tem o objetivo de contribuir na proteção, respeito e ao reconhecimento dos Direitos Humanos. O informe 2008 da Anistía Internacional é um documento que revela a situação dos Direitos Humanos em 150 países. Segundo a Anistía, o informe mostra um mundo dividido pela desigualdade, marcado pela discriminação e desfigurado pela repressão política. E, que ainda em todas as regiões do mundo se violam os Direitos Humanos com impunidade. Matam pessoas por suas crenças, mulheres são discriminadas e crianças exploradas através do trabalho infantil. Anistía Internacional Informe 2008-O estado dos Direitos Humanos no Mundo. Disponível em: http://www.es.amnesty.org/es. Acesso em 19.02.2009.

${ }^{175}$ LUÑO. Antonio Pérez. Los Derechos Fundamentales...Op. Cit Nota 3, (p.47).
} 
de los derechos fundamentales se tiende a aludir a aquellos derechos humanos garantizados por el ordenamiento jurídico positivo, en la mayor parte de los casos en su normativa constitucional y que suelen gozar de una tutela reforzada.

Isso significa dizer, que os Organismos internacionais devem agir no sentido de buscar a tutela desses direitos estando conscientes de que, o melhor caminho para emancipação integral do homem, é ter os seus direitos básicos respeitados. As empresas signatárias do Pacto Global, como pessoas jurídicas, tem o dever de respeitar esses direitos já que elas influenciam significamente na vida social da comunidade onde estão inseridas.

\section{Sobre o Trabalho}

O terceiro princípio do Pacto prevê que as empresas devem apoiar a liberdade de associação e o reconhecimento do direito a negociação coletiva dos seus trabalhadores. A observância dos direitos dos trabalhadores é a principal ferramenta para que as empresas contribuam na influência e na promoção dos Direitos Humanos, pois, sem isso, não há que se falar em responsabilidade social das empresas. Inclui-se aqui também, o direito a liberdade de expressão, a liberdade de associação sindical e a negociação coletiva. A liberdade de associação é um princípio que tem impacto sobre o fortalecimento da democracia, é um direito que permite aos trabalhadores reivindicar seu direitos, ademais, os Sindicatos e as aAssociações de trabalhadores formam parte importante na representação da sociedade. Já a Negociação coletiva só funciona de maneira eficaz, se for realizada livremente entre as partes, devendo resultar em negociações construtivas, evitando atrasos injustificados e respeitando os acordos celebrados. 
O quarto princípio é a eliminação de todas as formas de trabalho forçado ou compulsório. Trabalho forçado é qualquer atividade exigida de uma pessoa sob ameaça. O pagamento de salário ou de qualquer outra compensação não descarta que o trabalho não esteja sendo realizado de maneira forçada. Segundo dados da OIT há no mundo cerca de 12,3 milhões de pessoas vítimas do trabalho forçado, dessas pessoas 9,8 milhões são exploradas por agentes privados e 2,5 milhões são vítimas de trabalho forçado impostas pelo Estado ou por grupos insurgentes ${ }^{176}$. A OIT acrescenta ainda que esses números devem ser interpretados como número mínimo global estimado de pessoas atualmente em situação de trabalho forçado nos termos das Convenções n. 29 e 105. Relacionando essa estimativa com a população atual do mundo, calcula-se que em cada mil habitantes haja, pelo menos, duas vítimas de trabalhos forçados. Esses resultados confirmam que o trabalho forçado é um problema global que afeta um número significativo de pessoas, tanto em países desenvolvidos, como em desenvolvimento e em todas as regiões do mundo. Os números são maiores na região do Pacífico Asiático, seguidos pela América Latina, Caribe e pela África Subsaariana. O trabalho forçado também está presente em países industrializados, países de transição e em países do Médio Oriente ${ }^{177}$. Esse tipo de trabalho nos países industrializados se deve principalmente pelas consequências advindas do tráfico de pessoas, um número

\footnotetext{
${ }^{176}$ Trabalho forçado imposto por agentes privados para a exploração sexual comercial inclui mulheres e homens que entraram involuntariamente na prostituição ou em outras formas de atividades sexuais comerciais ou que entraram voluntariamente na prostituição e não podem deixá-la. Inclui também crianças forçadas a atividades sexuais comerciais. O trabalho forçado por agentes privados para a exploração econômica inclui o trabalho em regime de servidão, trabalho forçado doméstico ou trabalho forçado na agricultura ou em zonas rurais remotas. Trabalho forçado imposto pelo Estado, por militares para a participação compulsória em obras públicas e trabalho forçado em prisões. Esta última inclui não só os campos de trabalho forçado, mas também trabalho imposto em penitenciárias modernas semi privatizadas ou totalmente privatizadas e trabalho forçado impostos por grupos rebeldes. Fonte: Relatório da OIT: Uma Aliança Global contra o Trabalho Forçado. Relatório global de seguimento da OIT sobre Princípios e Direitos Fundamentais no Trabalho. (93a reunião/Genebra), 2005. Disponível em:<http://www.oitbrasil.org.br/trabalho_forcado/oit/relatorio/relatorio_global.php>. Acesso 20.03.2010. ${ }^{177}$ O número de pessoas em situação de trabalho forçado: Ásia e Pacífico (9.490.000), América Latina e Caribe (1.320.000), África Subsaariana (660.000), Países Industrializados (360.000), Oriente Médio e Norte da Africa (260.000), Países em Transição ( 210.000). No Mundo (12.300.00). Op. Cit. Nota anterior, (p.14).
} 
crescente de trabalhadores que deixam seus países de origem em busca de um emprego e de um salário melhor. Como os canais legais para a imigração são restritos, os traficantes se aproveitam desse fato e enganam mulheres e homens pouco qualificados ou sem nenhuma qualificação, subornando as autoridades para que entrem no país sem documentos legais. O tráfico ocorre também de forma mais direta, quando o próprio empregador recruta e transporta os trabalhadores de forma ilegal para obter ganhos à curto prazo.

É importante lembrar que, mesmo imigrantes regulares podem ser vítimas de trabalho forçado dependendo da região ou do país em que se encontram. O Protocolo para Prevenir, Abolir e Punir o Tráfico de Pessoas, especialmente mulheres e crianças da ONU diz, em seu artigo $3^{\circ}$, que o tráfico de pessoas refere-se ao recrutamento, transporte e transferência, por meio de ameaça ou força para fins de exploração sexual, da prostituição, do trabalho ou serviço forçado, escravidão ou práticas análogas à escravidão ${ }^{178}$. O número de pessoas nesta situação em consequência do tráfico chega a uma estatística assustadora. São, atualmente, 2.450.000 trabalhadores e a maioria deles, está na Ásia e Pacífico ${ }^{179}$.

O trabalho escravo no Brasil ainda é um assunto que merece atenção por parte do governo e das empresas. Pessoas são pagas com o objetivo de atrair trabalhadores para exercer atividades em locais afastados de suas cidades ou Estados de origem com promessas de salários mais altos e outras vantagens. Quando o trabalhador chega nessas localidades, recebe moradia, alimentação e às vezes vestuário, que são

\footnotetext{
${ }^{178}$ Protocolo para prevenir, Abolir, Punir o Tráfico de Pessoas, especialmente mulheres e crianças, que complementa a Convenção das Nações Unidas contra o Crime Organizado Transnacional. Documento em espanhol disponível em:< http://www2.ohchr.org/spanish/law/>. Acesso em 20/01/2010.

${ }^{179} 1.360 .000$ pessoas traficadas na Ásia e Pacífico, 270.000 nos Países Industrializados, na América Latina e Caribe são 250.000. Oriente Médio e Norte da África 230.000, nos Países em Transição 200.000 pessoas e na África Subsaariana 130.000. Dados do Relatório da OIT: Uma Aliança Global Contra o Trabalho Forçado (...). Op. Cit. Nota 176, (p.15).
} 
descontados do salário. Geralmente, os valores cobrados por essa manutenção são bem mais altos do que o normal, em consequência disso, o trabalhador nunca consegue saldar as dívidas e é impedido de deixar o local de trabalho sob ameaças. As jornadas de trabalho são elevadas e o ambiente é precário. Os alojamentos, muitas vezes, apresentam condições desumanas, quartos sem armários, banheiros sem portas, comida e água em péssimas condições de armazenamento. Outro agravante é que os trabalhadores exercem suas atividades sem nenhum conhecimento das regras de segurança e sem equipamentos de trabalho adequados. Como o empregado só pode ir embora se pagar as dívidas, ele fica a mercê dos empregadores e a servidão se torna inevitável. O isolamento geográfico impede a fuga e eles são ameaçados por vigias armados caso tentam a fuga ${ }^{180}$.

O MTE no Brasil divulgou a Portaria $n^{\circ} 540 / 2004$, para cadastrar os empregadores que exploram trabalhadores na condição análoga à de escravos. Semestralmente é realizada a atualização do cadastro, onde é incluido o nome dos empregadores cujos autos de infração não estejam mais sujeitos aos recursos na esfera administrativa. É realizada a exclusão daqueles que, ao longo de dois anos, contados de sua inclusão no cadastro, sanam as irregularidades identificadas pela inspeção do trabalho e atendem aos requisitos previstos na Portaria. Por meio de ações fiscais coordenadas pela Secretaria de Inspeção do Trabalho, a Divisão de Erradicação do

\footnotetext{
${ }^{180} \mathrm{O}$ empregadores precisam estar cientes que o trabalho forçado pode ser conectado a diferentes práticas, como por exemplo: a falta de autorização para trabalhar, a venda de pessoas, o confinamento no local de trabalho, a coação psicológica para trabalhar apoiada por uma ameaça real de punição por desobediência, o endividamento induzido (falsificação de contabilidade, aumento de preços, redução do valor dos bens ou serviços produzidos, aumento excessivo taxas de juros, etc.), o engano ou as falsas promessas sobre tipo e as condições de trabalho, a retenção na fonte e não-pagamento de salários, a retenção de documentos de identidade, passaporte ou outros bens pessoais, a violência física contra o trabalhador, familiares ou colaboradores próximos, a violência sexual, a prisão ou outra forma de confinamento, a denúncia às autoridades (polícia, imigração, etc.) e deportação, etc. Fonte: The Labour Principles of the UN Global Compact - A Guide for Business (2008). O documento descreve como as empresas signatárias do Pacto devem tomar medidas pra implementação dos princípios no que refere ao trabalho. Documento disponível em inglês:<http://www.unglobalcompact.org/>. Acesso em 17.01.2010.
} 
Trabalho Escravo do MTE tem por objetivo erradicar o trabalho escravo e degradante, em focos territoriais previamente mapeados. A fiscalização do trabalho visa regularizar os vínculos empregatícios dos trabalhadores encontrados e demais consectários e libertá-los da condição de escravidão. No ano de 2009 foram inspecionados 324 estabelecimentos em 19 Estados brasileiros, onde 3.571 trabalhadores foram resgatados da condição de escravo ${ }^{181}$.

Como vimos, o número de trabalhadores que são escravizados e traficados é muito significativo. As diversas modalidades de trabalho forçado no mundo tem sempre em comum duas características: o uso da coação e a negação da liberdade, que, em ambos casos, apresentam uma grave violação dos Direitos Humanos. Apesar da proibição da prática do trabalho forçado ser consagrada na legislação da maioria dos países, através do Direito Constitucional, do Direito do Trabalho ou do Direito Penal, essa prática ainda apresenta grandes números. De acordo com Programa de Ação Especial de Combate ao Trabalho forçado da OIT (2007), os princípios pelos quais os líderes empresariais deveriam atentar no combate ao trabalho forçado e o tráfico de pessoas são, entre outros:

a) Ter uma política empresarial clara e transparente, definindo as medidas para impedir o trabalho forçado e o tráfico;

b) Formar auditores responsáveis de recursos humanos e controle de normas, no intuito de identificar práticas de trabalho forçado e procurar medidas de correção adequadas;

\footnotetext{
${ }^{181}$ A inspeção referida é formada por uma equipe de Fiscais do Trabalho, Procurador do Ministério Público do Trabalho e Agentes da Polícia Federal. Trabalhador resgatado refere-se ao trabalhador em situação análoga de escravo incurso em uma ou mais hipóteses do artigo 149 do Código Penal brasileiro: trabalho forçado, servidão por dívida, jornada exaustiva e/ou trabalho degradante. Fonte: Relatórios Específicos de Fiscalização para a Erradicação do Trabalho Escravo. Atualizado em 11.01.2010. Disponível em. < http://www.mte.gov.br/trab_escravo/default.asp>. Acesso em 16.01.2010.
} 
c) Fornecer informações regularmente aos acionistas e potenciais investidores, atraindo-os para os produtos e serviços onde exista um compromisso claro e sustentável da prática de ética empresarial, incluindo a prevenção do trabalho forçado;

d) Pomover Acordos e Códigos de Conduta por setor industrial (como a agricultura, a construção e os têxteis), identificando as áreas de risco de trabalho forçado, e tomar as adequadas medidas corretivas;

e) Tratar os trabalhadores imigrantes de forma justa;

f) Acompanhar cuidadosamente as agências que oferecem contratos de trabalho, especialmente as transfronteiriças, colocando numa lista negra para todas as que tenham utilizado práticas abusivas e o trabalho forçado;

g) Assegurar que todos os trabalhadores tenham contratos escritos, em um idioma que eles compreendam facilmente, especificando os seus direitos relativamente ao pagamento de salários, horas extras, retenção de documentos de identidade e outras questões relacionadas com a prevenção do trabalho forçado;

h) Encorajar a realização de eventos nacionais e internacionais entre intervenientes empresariais, identificando áreas problemáticas e partilhando boas práticas;

i) Contribuir para a realização de programas e projetos de assistência, através de formação profissional e de outras medidas adequadas às vítimas de trabalho forçado e de tráfico;

j) Construir pontes entre governos, trabalhadores, agências de aplicação da lei e a inspeção do trabalho, promovendo a cooperação na ação contra o trabalho forçado e o tráfico e encontrar meios inovadores de recompensar as boas práticas, em conjunto com os meios de comunicação. 
Dessa forma, cabe também as empresas signatárias ou não do Pacto Global identificarem se há indícios de trabalho forçado ou escravo em suas atividades. Mesmo nos países desenvolvidos há focos de trabalho escravo, por isso, o tema é concebido pelas Organizações internacionais e pelos Governos como um problema de alcance global.

Como quinto princípio, as empresas signatárias do Pacto Global devem contribuir para abolir de forma efetiva o trabalho infantil. Neste sentido, a OIT prevê que em todo o mundo mais de 200 milhões de crianças trabalham, realizando tarefas perigosas que causam danos irreparáveis a sua saúde física e mental, inclusive em países onde há leis que proíbem o trabalho de crianças. As crianças que trabalham, estão mais expostas ao tráfico de drogas, ao tráfico de pessoas e a escravidão sexual. A abolição efetiva do trabalho infantil é um dos desafios mais urgentes que o mundo enfrenta hoje, segundo a Organização.

Os países que ratificaram a Convenção da ONU sobre os Direitos da Criança de $1989^{182}$, se comprometeram a proteger a infância contra qualquer tipo de dano, mal trato, exploração, violência ou descuido. Mesmo assim, o tema é ainda muito delicado para ser discutido, principalmente nos países em desenvolvimento, onde crianças continuam a ser excluídas e invisíveis aos olhos dos governos e da sociedade. Segundo a UNICEF - Fundo das Nações Unidas para a Infância, a vulnerabilidade desses direitos à proteção infantil é a principal causa da exclusão de milhões de crianças

\footnotetext{
${ }^{182}$ Essa Convenção regulamenta pela primeira vez os direitos das crianças de uma forma obrigatória. O artigo 32 obriga os Estados-partes a proteger as crianças contra a exploração econômica, física e psíquica. O documento não só insiste na necessidade de proteção especial das crianças, assegura-lhes também os direitos clássicos, como, por exemplo, a liberdade de expressão e a informação. Considera a criança como sujeito autônomo de direitos, ou seja, como portadores de direitos e liberdades.
} 
no mundo ${ }^{183}$. As estimativas do Informe Global sobre trabalho infantil da OIT de 2006 indicam uma redução do números de crianças trabalhadoras nas economias emergentes da Europa e da Ásia Central, por causa do crescimento econômico e da redução da pobreza ligados ao compromisso político. Ademais, a taxa dos países Europeos que ratificaram as Convenções da OIT contra o trabalho infantil é alentadora.

No ano de 1992 o número de crianças que trabalhavam no Brasil atingiu o nível histórico de 9,6 milhões de trabalhadores entre os 05 e os 17 anos de idade, sendo 21,85\% da população dessa faixa etária. Em 2002 esse percentual se reduziu para $12,6 \%{ }^{184}$. Essa diminuição poderia ser explicada pela mudança da estrutura demográfica que indica um aumento da população com idade maior. No entanto, a partir dos anos 90, as políticas públicas contribuiram significativamente para essa diminuição. O combate ao trabalho infantil se deu de diferentes formas, como por exemplo: as ratificações das Convenções OIT 132 (idade mínima para admissão no emprego) e 182 (piores fomas de trabalho infantil), a efetivação dos direitos previstos na Constituição Federal de 1988 e no Estatuto da Criança e do Adolescente (Lei $n^{\circ}$ 8.069/90), que propiciaram a mobilização do governo e da sociedade civil para começar o processo de erradicação do trabalho infantil. Criaram-se também, programas governamentais como o Programa de Erradicação do Trabalho Infantil (PETI) e o Bolsa Família ${ }^{185}$. De acordo com a OIT

\footnotetext{
${ }^{183}$ Informe da UNICEF 2006. Estado mundial da Infância - excluídos e invisíveis. Nesse documento a Unicef faz referência a respeito das empresas e do trabalho infantil, dizendo que "Las organizaciones del sector privado, entre ellas las organizaciones comerciales, cámaras de comercio y otros miembros de la comunidade empresarial, tienen también importantes funciones que desempeñar en la inclusión de la infancia. Son aliados en el fomento de un entorno protector para la niñez, asegurando que sus actividades nunca causen daños a los niños y niñas ni permitan su explotación. Una de las maneras más eficaces en que las organizaciones del sector privado pueden realizar esta labor es por medio de la responsabilidad social empresarial, creando y cumpliendo códigos de conducta, y concienciando y capacitando a su persona”. Disponível em: <http://www.unicef.org/spanish/sowc06/pdfs/sowc06_fullreport_sp.pdf>. Acesso em 20.02.2009.

${ }^{184}$ Fonte: Informe IPEC - Programa Internacional para a Eliminação do Trabalho Infantil e SIMPOC Programa de Informações Estatísticas de Monitoramento sobre o trabalho Infantil (OIT/2004), (p.13).

${ }^{185}$ O PETI é um dos programas do Governo Federal que articula um conjunto de ações visando retirar crianças e adolescentes com idade inferior a 16 anos da prática do trabalho precoce, exceto na condição de aprendiz a partir de 14 anos. O Programa Bolsa Família (PBF) é um programa de transferência direta
} 
Brasil "a persitência de uma forte ideologia relativa "ao benefício" do trabalho infantil aliada a incapacidade do Estado de ampliar sua intervenção parecem constituir as grandes barreiras para a erradicação efetiva desse problema social." Acreditamos que o "benefíco", que inclui o Programa Bolsa Família é bem vindo, na medida em que ele exige certas condições para que os pais possam receber dinheiro da ajuda. Os pais devem cuidar da sáude e da educação dos seus filhos em troca do benefício, a frequência escolar da criança beneficiada, deve ser de no mínimo de $85 \%$ de crianças e adolescentes ente 06 e 15 anos de idade e $75 \%$ para adolescentes entre 16 e 17 anos. Quanto a saúde, o programa acompanha o calendário das vacinas, do crescimento e do desenvolvimento das crianças menores de 07 anos de idade. É previsto o pré-natal de gestantes entre 14 e 44 anos e ainda, assistência social, ou seja, frequência mínima de 85\% da carga horária relativa aos serviços sócios educativos para crianças e adolescentes até 15 anos de idade. O objetivo das condições para receber o benefício, segundo o governo, não é punir as famílias, mas, responsabilizá-las para que as crianças se mantenham na escola e longe do trabalho.

De um modo geral, as crianças que trabalham no Brasil provém de famílias de baixa renda, que, dentre outros fatores, esse é considerado o mais importante. A erradicação do trabalho infantil fica inviabilizada, na medida em que, a pobreza e a exclusão social são fortemente acentuadas no país. Para tanto, cabe as empresas siginatárias do Pacto que operam no país e/ou fora dele atentarem para a exploração infantil, em toda a rede de produção envolvendo seus stakeholders e a sociedade na qual está inserida. Nesse sentido, o Guía del Pacto Global - Una forma

de renda com condicionalidades, que beneficia famílias em situação de pobreza (com renda mensal por pessoa de $\mathrm{R} \$ 70,00$ a $\mathrm{R} \$ 140,00$ ) e extrema pobreza (com renda mensal por pessoa de até $\mathrm{R} \$ 70,00$ ), de acordo com a Lei 10.836, de 09 de janeiro de 2004 e o Decreto $\mathrm{n}^{\circ}$ 5.209, de 17 de setembro de 2004. Para saber mais sobre o Programa Bolsa Família. Acesse o site do Ministério de Desenvolvimento Social e combate à fome: http://www.mds.gov.br/suas/. Acesso em 24.01.2010. 
práctica para implementar los nueve principios en la gestión empresarial, acrescenta que,

Las empresas no deben utilizar mano de obra infantil bajo modalidades socialmente inaceptables que puedan contribuir a que los niños pierdan oportunidades educativas o de desarrollo de sus capacidades. La complejidad de la problemática del trabajo infantil supone que las empresas deben abordar la cuestión de una forma sensible y integral y no tomar medidas que pueden dejar a los niños en manos de modalidades de explotación aún más peligrosas. Sin embargo, tal como establece el principio $\mathrm{V}$, el objetivo de toda empresa debería ser a la abolición del trabajo infantil dentro de su esfera de influencia ${ }^{186}$.

Eliminar a discriminação no emprego é o sexto princípio do Pacto

Global. O princípio da igualdade integra o rol dos direitos e liberdades fundamentais e a discriminação no trabalho constitui uma negação a esse princípio. Entretanto, há uma diferença entre a discriminação positiva e a negativa. A discriminação positiva é aquela que não caracteriza infração ao princípio da igualdade, objetiva a inclusão da pessoa no mercado de trabalho por circunstâncias especiais, criando condições para favorecer as vítimas da desigualdade, pois, trata preferencialmente dos grupos mais desfavorecidos. Já a discriminação negativa tem por base a desigualdade de tratamento por motivo injustificado, ou seja, concretiza-se pela exclusão. ROMITA $^{187}$ contribui dizendo que,

O direito do trabalho se nutre de desigualdades: haja vista a grande quantidade de normas que regulam de maneira diversa da comum, o trabalho das mulheres e dos adolescentes, a regulamentação profissional, os chamados contratos especiais de trabalho, etc (...) $\mathrm{Na}$ hipótese inversa (discriminação negativa) a vedação de discriminação

\footnotetext{
${ }^{186}$ Guia del Pacto Global. Una forma práctica para implementar los nueve principios en la gestión empresarial. Buenos Aires (2004), (p.58). Disponível em: <http://unglobal.org>. Nesta data o $10^{\circ}$ princípio do Pacto ainda não havia sido implantado.

${ }^{187}$ ROMITA, Arion Sayão. Direitos Fundamentais nas Relações de Trabalho. Apud: ALKIMIN, Maria Aparecida. Violência na Relação de Trabalho (...). Op. Cit. Nota 33, (p.114).
} 
constitui modalidade de realização prática da noção de justiça, pois repita-se - nada mais injusto se pode imaginar do que tratar de modo desigual alguém, em confronto com os demais situados em posições iguais, com o resultado da provação de direitos.

Nesse escopo, HIRIGOYEN diz que todo assédio é praticamente um ato discriminatório porque, a pessoa que discrimina, recusa a outra por causa de uma diferença ou de uma particularidade. A discriminação é dissimulada, tendo em vista a proibição por lei, por isso, pode se transformar em assédio moral. O assédio discriminatório é bem pontual. Assedia-se o trabalhador por apresentar alguma deficiência física ou limitação, por motivos raciais, religiosos ou por função de orientação sexual $^{188}$.

Entretanto, acreditamos que o simples fato de discriminar uma pessoa no ambiente de trabalho não gera o assédio, o que gera o assédio moral, sexual ou por razão de sexo é a insistência e a perseguição em torno de um motivo como vimos anteriormente. Em outras palavras significa dizer que, nem toda discriminação configura-se assédio.

OLIVEIRA $^{189}$, citando outros autores, escreve: "no se puede afirmar con caracter general que las conductas acosadoras son discriminatorias. Pero sí puede decirse que tales conductas son discriminatorias siempre que las causas prohibidas sean utilizadas, al menos indirectamente, para hostigar al trabajador. Também não é verdade que somente as pessoas que pertençam as categorias ou grupos protegidos frente à discriminação estão sujeitas a ser assediadas moral ou sexualmente.

\footnotetext{
${ }^{188}$ HIRIGOYEN, Marie France. Mal-estar no Trabajo... Op. Cit Nota 98, (p.103).

${ }^{189}$ GONZALES DE PATTO, R. M. La Resolución... Apud: OLIVEIRA, Flavia. El Acoso Laboral. Valencia, 2005. Tese. Departamento de Derecho del Trabajo y de La Seguridad Social. Universitat de Valencia, (p.188).
} 
A discriminação negativa pode ser direta ou indireta. A direta ocorre quando, por motivos de raça ou etnia, religião, crença, deficiência, idade ou orientação sexual, uma pessoa é tratada de maneira menos favorável, em relação à outra. A indireta ocorre quando há uma disposição ou critério aparentemente neutros, que coloca pessoas numa situação de desvantagem em razão da raça, etnia, religião ou crença, deficiência, idade ou orientação sexual. Essa prática ou critério deve ser justificada através de um objetivo legítimo.

Quando BANDEIRA DE MELLO ${ }^{190}$ pergunta: quem são os iguais e quem são os desiguais? Que espécie de igualdade veda e que tipo de desigualdade faculta a discriminação de situações e de pessoas, sem quebra e agressão aos objetivos do princípio constitucional da isonomia? Ao tentarmos responder essas questões inquietantes utilizamos as palavras de KELSEN, quando diz que a igualdade dos sujeitos na legislação, não significa que estes devam ser tratados de maneira idêntica. A igualdade, assim entendida, não é concebível e seria um verdadeiro absurdo impor a todos os indivíduos exatamente as mesmas obrigações ou, lhes conferir exatamente os mesmo direitos, sem fazer distinção nenhuma entre eles ${ }^{191}$, como por exemplo as vagas reservadas em concursos públicos para deficientes físicos ou as vagas nas grandes redes comerciais para pessoas portadoras de algum tipo de deficiência ou, ainda, as cotas em universidades para negros. Esse tipo de política é positiva na medida em que inclui os trabalhadores nos diversos ramos de atividades.

Nesse diapasão, defendemos que as ações afirmativas, devam ser desenvolvidas por meio de políticas públicas e privadas com o objetivo de eliminar desigualdades historicamente acumuladas, garantindo a igualdade de tratamento e

\footnotetext{
${ }^{190}$ MELLO, Celso Antonio Bandeira de. Conteúdo Jurídico do Princípio de Igualdade. $3^{\text {a }}$ edição. São Paulo: Malheiros, 2009, (p.11).

${ }^{191}$ KELSEN HANS. Apud: Op. Cit. Nota anterior.
} 
concretizando o princípio constitucional da igualdade de trato, buscando neutralizar os efeitos da discriminação racial, de gênero, de idade, de origem nacional, de religião, de compleição física, etc. As ações afirmativas podem e devem ser desenvolvidas fora do Estado por partidos políticos, sindicatos, escolas e igrejas e empresas. Nas palavras de PIOVESAN ${ }^{192}$, as ações afirmativas objetivam acelerar o processo de igualdade com o alcance da igualdade substantiva por parte de grupos socialmente vulneráveis, como as minorias étnicas e raciais, dentre outros grupos. Elas devem ser compreendidas não somente pelo prisma retrospectivo - no sentido de aliviar a carga de um passado discriminatório -, mas também prospectivo - no sentido de fomentar a transformação social, criando uma nova realidade. E, prossegue, afirmando que o que se pretende é garantir a igualdade de fato, com a efetiva inclusão social de grupos que sofreram e sofrem um consistente padrão de violência e discriminação. Importante aqui é frisar que essas ações não podem ser confundidas como ações protetoras e sim entendidas como medidas que promovam a abolição da discriminação seja ela qual for.

Além disso a discriminação no mundo do trabalho é uma forma de violar os direitos fundamentais das pessoas que causa graves problemas sociais e econômicos. A discriminação no trabalho, desestimula o ser humano, cria enfermidades e acelera o processo de desigualdade social. Esses princípios referentes a temática sobre o trabalho nos remetem aos da Declaração da OIT de 1998 sobre os Princípios e Direitos Fundamentais no Trabalho que, segundo a Organização, é uma expressão de compromisso por parte dos governos, empregados e organizações de trabalhadores para

\footnotetext{
${ }^{192}$ PIOVESAN, Flávia. Ações Afirmativas no Brasil: desafios e perspectivas. Scielo Brasil. Revista Estudos Feministas, volume 16, nº 03, Florianópolis (SC), Setembro/Dezembro/2008.
} 
defender os valores humanos fundamentais. A Declaração da OIT $^{193}$ sobre os princípios e direitos fundamentais no trabalho aborda um princípio interessante dizendo que,

Trabalho Decente é uma condição fundamental para a superação da pobreza, a redução das desigualdades sociais, a garantia da governabilidade democrática e o desenvolvimento sustentável. Entende-se por Trabalho Decente um trabalho adequadamente remunerado, exercido em condições de liberdade, equidade e segurança, capaz de garantir uma vida digna.

De acordo com a Rede Espanhola do Pacto Global, as empresas devem tomar medidas para abordar a questão da discriminação, eliminando-as do local de trabalho e criando uma política transparente aplicável a toda a atividade que desenvolvem. Devem adotar procedimentos para orientar as práticas de contratação, objetivando a igualdade de oportunidades, evitando que os requisitos exigidos para determinados cargos não apresentem sistemáticas desvantagens para determinados grupos. Acrescenta também, que quando são detectados casos de discriminação, a empresa deverá criar espaço para que as pessoas façam suas queixas e denúncias, entre outras sugestões.

\section{Sobre o Meio Ambiente}

A idéia do desenvolvimento econômico não pode estar pautada na distruição dos ambientes naturais, das desigualdades sociais, da má distribuição de renda e em outros dilemas sociais, porque, as ações econômicas estão relacionadas com a sociedade como um todo. As empresas devem vencer o desafio de tornar realidade os princípios e práticas de desenvolvimento sustentável. Quando dissertamos sobre

\footnotetext{
${ }^{193}$ Ministério do Trabalho e Emprego. Ministério do Trabalho. Agenda Nacional de Trabalho Decente. Disponível em: <http://www.mte.gov.br/antd/default.asp>. Acesso em 28.01.2008.
} 
desafios ambientais, devemos trazer a palavra sustentabilidade, que existe desde o século XVIII e XIX, quando foram lançadas as bases da produção do sistema capitalista. Somente nos anos 70 e 80 é que começaram a surgir, de maneira mais forte e, sobretudo, nas empresas e nas formas de gestão manifestadas através da preocupação com o meio ambiente, especialmente na Europa, a necessidade de atentar para isso.

Segundo, o caderno: PROFI - Sustentabilidade e Futuro do Banco do Brasil $^{194}$, o crescimento magnífico que a modernidade nos proporcionou, se deu a partir de quatro crenças equivocadas:

1) A de que as forças do mercado regulam a oferta e a procura, se a demanda exercer a oferta, os recursos ficarão caros. Em consequência disso, novas fontes serão encontradas ou vão se desenvolver alternativas tecnológicas. Enquanto o sistema de preços de mercado funcionar e a inovação tecnológica prosseguir, não teremos problemas de escassez;

2) Os recursos naturais são infinitos;

3) Os poderes do homem sobre as forças da natureza e sua capacidade de resolver os problemas gerados pelo desenvolvimento são ilimitados;

4) Os problemas deixados pela civilização contemporânea serão resolvidos pelas gerações futuras.

Essas premissas, passaram a ser questionadas, pois, esse modelo de desenvolvimento teve um trágico resultado: a degradação ambiental. As discussões sobre a sustentabilidade do sistema e, por conseguinte, das empresas, incorporam, a partir de então, além da preocupação com a sobrevivência econômica, a dimensão social e ambiental. Sendo assim, a responsabilidade social corporativa é uma decisão de

\footnotetext{
${ }^{194}$ PROFI - Universidade Corporativa do Banco do Brasil - Sustentabilidade e Futuro. Edição: Versal Multimídia, Brasília (DF), circulação: Junho de 2008.
} 
negócios baseada em valores éticos, em respeito pelo meio ambiente, pela comunidade e pelo ser humano.

Em 1972 a ONU organizou em Estocolmo a primeira Conferência Internacional sobre o Meio Ambiente Humano. O primeiro princípio da Declaração introduziu conceitos ligados aos Direitos Humanos, ao direito à liberdade, à igualdade e ao desfrute de condições de vida adequadas em um meio ambiente de qualidade tal, que permitisse ao homem levar uma vida digna, tendo a obrigação de proteger e melhorar o meio ambiente para as gerações presentes e futuras. Depois disto, foi criada pela ONU a Comissão Mundial sobre o Meio Ambiente e Desenvolvimento (1983) presidida por BRUNDTLAND, pautando o reexame das questões críticas do meio ambiente e do desenvolvimento. Em 1987 foi construído o Relatório Brundtland, publicado com o título "Nosso Futuro Comum", surgindo então, pela primeira vez o conceito de "Desenvolvimento Sustentável", embora anteriormente, ele já estivesse em gestação, com outros nomes. Em 1992, 178 países se reuniram na cidade do Rio de Janeiro para estabelecer metas para combater os males causados pelo uso indevido dos recursos naturais, gerando a Declaração do Rio sobre Meio Ambiente e Desenvolvimento, que definiu os direitos dos povos ao desenvolvimento e também suas responsabilidades para a proteção do meio ambiente comum. O objetivo principal da Declaração é de buscar meios para conciliar o desenvolvimento sócio-econômico com a conservação e proteção dos ecossistemas do planeta. A Agenda 21, já comentada neste trabalho, foi o principal Documento produzido na RIO-92. Ela viabiliza um novo modelo de ação, um desenvolvimento ambiental racional, defende métodos de proteção ambiental, justiça social e eficiência econômica. Porém, mais de uma década depois, o Documento ficou só nas boas intenções, porque, na verdade, o crescimento da economia global foi proporcional à degradação causada ao ambiente. 
Nesse sentido, a adoção pelas empresas de princípios e de ações compatíveis com os ideais de sustentabilidade e responsabilidade socioambiental tem se tornado o grande desafio do momento. A gestão de negócios socialmente responsáveis é um dos fundamentos que a sociedade civil e os governos somam esforços para que seja viabilizado através de um modelo de desenvolvimento que leve em conta a qualidade de vida das pessoas ${ }^{195}$. Neste aspecto, "Negócios sustentáveis indicam o potencial de uma nova abordagem para o desenvolvimento baseada na atuação do setor privado, capaz de gerar negócios lucrativos, melhorar a qualidade de vida dos mais carentes do mundo, respeitar a diversidade cultural e conservar a integridade ecológica do planeta. Oferecer essa contribuição social enquanto se cria valor para os acionistas, requer inovação e criatividade nas estratégias de negócio ${ }^{196}$.

Dentro disso, e como sétimo princípio do Pacto Global diz que as empresas devem apoiar uma abordagem preventiva aos desafios ambientais. A proteção do meio ambiente se processa como parte integral do desenvolvimento, e o elemento chave é o enfoque preventivo, do ponto de vista empresarial, resultando mais rentável a adoção de medidas preventivas que garantam que a empresa não causará dano ao meio ambiente, a fim de implementar o enfoque preventivo ${ }^{197}$. Pensando na prevenção, o indicador 21 do Instituto Ethos, faz as seguintes recomendações:

\footnotetext{
${ }^{195}$ SOUZA, Perci e SOARES, Francilene. Responsabilidade Socioambiental. Universidade de Brasília, Centro de Educação à Distância. Brasilia, 2006, ( p.55).

${ }^{196}$ Stuart Hart e C.K. Prahalad, 2004. Apud: Nota anterior.

${ }^{197 ، " E l ~ p r i n c i p i o ~ d e ~ p r e v e n c i o ́ n ~ s e ~ r e s u m e ~ c o m o ~ m e j o r ~ a s e g u r a r s e ~ p r i m e r o ~ q u e ~ l a m e n t a r l o ~ d e s p u e ́ s ~ y ~ e s t a ́ ~}$ enfocado a desplazar la carga de la prueba en las demandas sobre daños ocasionados al medioambiente. Históricamente ha existido una tendencia a asumir que las emisiones de gases industrial e seran inocentes hasta que se demostrara lo contrario de haber cometido daños ambientales. El principio preventivo sugiere que determinados tipos de emisiones deben ser consideradas culpables por su propia naturaleza y se deben realizar esfuerzos encaminados a reducir dichas emisiones, incluso en ausencia de pruebas de que hayan causado efectos medioambientales particulares. Después de todo, es demasiado tarde para preocuparse sobre las pruebas de vinculación causa - efecto una vez que se haya causado un daño ecológico". T. JACKSON (1996). Apud: Guia del Pacto Global ....Op.Cit. Nota 186.
} 
- Desenvolver ações de educação ambiental e treinamento dos empregados sobre essa temática, pontualmente ou em decorrência de pressão externa (como exigências do governo);

- Desenvolver sistematicamente atividades de educação ambiental focadas no público interno, disponibilizando informações e promovendo discussões;

- Desenvolver campanhas de conscientização dirigidas às famílias dos funcionários, empregadores, fornecedores, consumidores, clientes e à comunidade do entorno imediato da empresa;

- Apoiar e participar de projetos educacionais em parcerias com organizações não-governamentais e ambientalistas, exercendo liderança social em favor da causa $^{198}$.

A Educação Ambiental para Empresas deve ser um processo de aprendizagem permanente, a fim de firmar valores e ações que contribuam para a transformação humana, social e a preservação ecológica. Ela é parte fundamental de qualquer projeto de sustentabilidade, já que a melhoria do meio ambiente do entorno, facilita a melhoria do meio ambiente laboral e pode evitar casos de desrespeito aos Direitos Humanos e, inclusive, de assédio.

As empresas devem desenvolver iniciativas para promover maior responsabilidade ambiental, é o oitavo princípio da iniciativa. A responsabilidade ambiental se torna imprescindível porque, a tendência global não é nada otimista dado que as estatísticas sobre a mudança climática, a contaminação do ar, o aquecimento global e o efeito estufa são assustadoramente altas. Recentemente em Copenhague aconteceu a $15^{\text {a }}$ Conferência Sobre o Clima da ONU, onde o objetivo era chegar a um

\footnotetext{
${ }^{198}$ Instituto Ethos. Op. Cit. Nota 156.
} 
acordo mundial para conter o ritmo do aquecimento global. Mas, segundo a própria comunidade internacional, o encontro não gerou muitos resultados significativos. Isto porque, as estimativas não são nada animadoras para o nosso planeta principalmente no que diz respeito ao aumento da população e a escassez dos recursos naturais. Segundo estatísticas, o atual ritmo de crescimento da população mundial é 213.000 pessoas por dia. Até o ano de 2.050, estima-se que o planeta terá que abrigar 2,4 bilhões de pessoas a mais e a expectativa de vida que, hoje é de 67 anos em 2.050 será de 75 anos de idade $^{199}$. A preocupação geral é como chegar lá sem grandes problemas, pois, os recursos naturais estão ficando escassos e a falta de comida e água são inevitáveis. Segundo o Pacto Global alguns elementos chaves que contribuem para melhorar a responsabilidade da empresa com o meio ambiente são a aplicação do enfoque preventivo, a adoção das mesmas exigências operativas independentemente do lugar das atividades, a ação de aprofundar a discussão sobre as questões meio ambientais na empresa e dialogar com a comunidade local, entre outras.

Incentivar o desenvolvimento e difusão de tecnologias ambientalmente amigáveis, vem como nono princípio da iniciativa. Para o Pacto Global as tecnologias consideradas respeitosas com o meio ambiente, são aquelas assinaladas no capitulo 34 da Agenda 21, quando afirma que as tecnologias ambientalmente saudáveis protegem o meio ambiente, são menos poluentes, usam todos os recursos de forma mais sustentável, reciclam mais seus resíduos, tratam os dejetos residuais de uma maneira mais aceitável do que as tecnologias que vieram substituir. As tecnologias limpas são benéficas para a preservação do meio ambiente, podendo ser utilizadas com a finalidade de reduzir ou eliminar os resíduos produzidos. Em uma fábrica ou em uma unidade de negócio, por

\footnotetext{
${ }^{199}$ FRANÇA, Ronaldo. Fome de ar, água e comida. Revista Veja, Edição 2143, ano 42, nº 50, São Paulo, 16 de dez/ 2009, (pp.133-146).
} 
exemplo, a melhora do uso da tecnologia, segundo o Pacto pode se desenvolver por quatro princípios básicos: mudanças nos processos de fabricação desde as mais simples até as mais sofisticadas que requerem esforços e investigação, substituição de matérias primas por outras menos tóxicas, variações de produtos, como por exemplo, a troca de pinturas fabricadas por pinturas de água, a reutilização de materiais na fabricação, a separação e o tratamento de materiais úteis a partir de resíduos. Os métodos e/ou equipamentos que garantem a preservação do meio ambiente vão desde estratégias ou a utilização de produtos simples até invenções mais sofisticadas, proporcionando qualidade de vida da comunidade onde a empresa está inserida e garantindo uma imagem socialmente responsável.

\section{Contra a Corrupção}

E, finalmente, como décimo princípio temos o combate a corrupção em todas as suas formas, inclusive a extorsão e a propina ${ }^{200}$. O combate a corrupção, atualmente, é um dos maiores desafios no mundo. Ela constitui um obstáculo para o desenvolvimento da economia, principalmente nos países subdesenvolvidos. Segundo o Pacto Global, a adoção desse princípio, faz com que as empresas participantes não somente evitem o suborno e a extorsão, mas também, desenvolvam políticas e programas para eliminar a corrupção, unindo-se com os organismos das Nações Unidas, os Governos e a Sociedade Civil, para que a economia se processe de forma mais transparente. Dessa maneira, impulsiona as empresas signatárias do Pacto a adotarem estratégias contra corrupção, fazendo com que, protejam seus negócios, sua reputação e os interesses de seus acionistas.

\footnotetext{
${ }^{200}$ Corrupção é o abuso do poder em qualquer esfera em benefício próprio. Extorsão é o ato de obrigar alguém de fazer ou deixar de fazer alguma coisa para obter vantagem, recompensa ou lucro, tipificado como crime no Código Penal Brasileiro artigo 158. Propina: suborno ou qualquer tipo de dinheiro pago em troca de favor ilícito.
} 
Dentro disso, vale destacar que a Transparência Internacional, uma Organização da sociedade civil, líder na luta contra a corrupção, realiza constantemente seminários que reúnem os governos, a sociedade civil, as empresas e os meios de comunicação para promover a transparência na administração pública em matéria de negócios. De acordo com a Transparency Internactional (TI) ${ }^{201}$, as consequências da corrupção são mundiais e de ordem econômica, social e política, deixando muitas pessoas na pobreza e na miséria. A corrupção, nega aos mais desfavorecidos acesso aos meios básicos de sobrevivência, afetando o comércio e os negócios internacionais. No plano empresarial a corrupção aumenta os custos provocando inseguranças, colocando em risco a reputação da empresa e gerando vulnerabilidade à extorsão, prejudicando a avaliação da empresa, distruindo moralmente a equipe. Quando há corrupção, em um ambiente mais amplo a competição se torna desleal, desqualificando a licença social de operação, anulando a legitimidade e a confiança da organização. As empresas que têm estratégias e planos para combater a corrupção e normas éticas sofrem até $50 \%$ menos a corrupção e estão menos sujeitas a perder oportunidades de negócios do que as empresas que não possuem estratégias ou programas de combate à corrupção. Acreditamos que isso também se reflete nos casos de violações aos direitos dos trabalhadores.

Sendo assim, as empresas se comprometem a montar suas estratégias dentro dos dez princípios universalmente propostos, contribuindo para a construção de um mercado global mais estável. A iniciativa, já abrange mais de 100 países em todo o

\footnotetext{
${ }^{201}$ Fundada em 1983 a TI é uma organização global da sociedade civil que lidera a luta contra a corrupção, possui escritórios distribuídos em 90 países com o objetivo de construir um movimento anticorrupção, é uma organização não partidária, não leva a cabo a investigação de crimes de corrupção mas contribui com as entidades que realizam essa tarefa. A organização desenvolve com a cooperação do setor privado e da sociedade civil modelos que apóiam as empresas na implementação de sistemas anticorrupção e ferramentas que reforçam a transparência nos processos de licitações públicas. Ver mais em: <http//:www.transparency.org>. Acesso em: 20.02.2009.
} 
mundo, entre eles o Brasil e a Espanha. Com isso, podemos afirmar que o Pacto Global pode ser considerado uma das maiores iniciativas de cidadania corporativa do mundo.

Em 2007 os coordenadores do Pacto Global reuniram-se com os principais líderes da rede e, nesse encontro, os participantes tiveram a oportunidade de realizar uma auto avaliação franca dos seus resultados, renovando o compromisso. Ademais, houve um aumento de firmantes e de novas redes empresariais. Atualmente, as redes locais que são estruturadas a nível nacional e regional, tem por objetivo apoiar a aplicação do princípio e se reúnen uma vez por ano para compartilharem experiências, revisar e comparar os progressos. Recentemente em Istambul, aconteceu o VII Fórum Anual dos Comitês Locais do Pacto Global, que reuniu representantes de 80 países, onde foi enfatizada a importância das empresas sustentáveis em uma época de recessão global com debates e troca de experiências, discussões, avanços e o balanço de trabalho até agora realizado. Encontros como estes, são fundamentais para analisar e promover a implementação dos princípios do Pacto. Até porque, para garantir o progresso da iniciativa, além dos princípios, foram também estabelecidos deveres, entre os quais, estão os de que os membros devem expressar um compromisso público, promovendo os princípios e publicando suas "práticas e experiências" no que refere as estratégias que incluem os objetivos da iniciativa.

No Brasil, o Comitê Brasileiro do Pacto Global (CBPG), foi criado através do Instituto Ethos e com parceria do Programa das Nações Unidas para o Desenvolvimento (PNDU) em 2003. Ele tem por objetivo promover a adoção dos princípios do Pacto Global nas empresas que operam no Brasil, desenvolvendo o movimento de Responsabilidade Social. O Comitê brasileiro é composto por até 35 Organizações convidadas. Recentemente, o CBPG realizou uma importante estratégia, 
criando comissões que funcionam como um espaço de diálogo e discussão em torno da integração das empresas siginatárias do Pacto, como as comissões de Direitos Humanos e Trabalho, de Meio Ambiente, de Anticorrupção e a Comissão de Educação. É interessante a iniciativa do Comitê brasileiro, porque, as comissões não só promovem a discussão entre as empresas siginatárias mas, também, ampliam a rede de empresas participantes.

Na Espanha, no ano de 2002, a Fundación Rafael del Pino, pôs em marcha um movimento de adesão de empresas espanholas e outras entidades, com o objetivo de promover e implantar o Pacto Global. Em seguida, foi criado o Comitê de Coordenação para impulsionar as tarefas, com um diálogo entre empresas, ONGs, Fundações, Sindicatos e Entidades educativas interessadas na implementação do Pacto naquele país. Assim, foi criada a Associação Espanhola do Pacto Mundial (ASEPAM). As empresas espanholas estão aderindo e avançando em temas como a responsabilidade corporativa das empresas sintonizadas com os dez princípios do Pacto. Em 2004, a ASEPAM realizou um estudo sobre a implantação dos dez princípios adotados pelas empresas espanholas. O objetivo do estudo, que foi realizado através de um questionário, buscou verificar o grau de implantação dos nove princípios, já que o décimo, foi aprovado em 2004. Esse estudo resultou na elaboração do Documento intitulado Libro Azul de 2004 - La Implantación del Pacto Mundial de Nações Unidas en las Empresas Españolas, descrevendo os objetivos do Pacto e trazendo os resultados referentes a pesquisa realizada. O Documento espanhol sobre o Pacto Global, teve como filosofia e compromisso, a implantação dos princípios revistos no Pacto, até alcançar o grau de excelência. 
O questionário da pesquisa ${ }^{202}$ se dirigiu a três tipos de empresas que assinaram o Pacto Global na Espanha: grandes empresas (mais de 250 trabalhadores), pequenas e médias empresas (menos de 250 trabalhadores) com cadeias de distribuição comerciais em outros países e pequenas e médias empresas locais (menos de 20 trabalhadores) no âmbito espanhol de atividade. As respostas das grandes empresas espanholas foram compreendidas da seguinte forma. Nenhuma empresa que respondeu o questionário, considera que seu desempenho na implantação do Pacto Mundial tenha sido excelente. Mas, a maioria, acredita que os esforços para sua implantação tenham sido bons. Dessas empresas, $86 \%$ têm uma declaração de valores e uma missão, que é a pedra angular de sua responsabilidade social, o que demonstra um forte compromisso. Destacaram-se também, a posição favorável que as empresas têm de levar adiante os compromissos assumidos com o Pacto Global, tais como: responsabilidade social e cidadania corporativa. No que respeita a proteção aos Direitos Humanos de seus trabalhadores, $78 \%$ das empresas, estão cumprindo, e, $90 \%$ das empresas espanholas, têm políticas explícitas e pessoas responsáveis para atuarem nos sistemas de monitoramento ao respeito as normas laborais.

Sessenta por cento das grandes empresas espanholas que fizeram parte da pesquisa, implementaram políticas de desenvolvimento social nas áreas em que operam. Em termos comparativos, as empresas espanholas dedicam mais esforços a este trabalho social que ao ativismo público ou privado em defesa das normas laborais dignas em outros países onde operam. As informações a respeito dos princípios, das políticas e dos sistemas de gestão, demonstraram que, cerca de $76 \%$ das empresas utilizam uma política de transparência. Quanto a implantação dos princípios relacionados ao meio ambiente, as empresas pesquisadas demonstraram que encontram-se em uma situação

\footnotetext{
${ }^{202}$ Disponível em: <www.pactomundial.org/recursos/documentos/Materiales/cuestionario 040308.pdf>. Acesso em 24.02.2009.
} 
excelente, tanto em termos de política quanto em procedimentos de informação e sistemas de controle e monitoramento. Nesse sentido, 93\% das empresas têm políticas explícitas e pessoas responsáveis, procedimentos e monitoramentos se cumprem em mais de $83 \%$ das grandes empresas espanholas. E, por último, $73 \%$ das grandes empresas trabalham mediante mecanismos formalizados no diálogo com as organizações civis de meio ambiente. Este estudo, confirma que, as empresas espanholas que aderiram ao Pacto Global, avançam na implantação de políticas de responsabilidade social.

Entretanto, até o ano de 2005, o Pacto Global não contava com nenhum tipo de mecanismo que pudesse acompanhar ou avaliar o compromisso que as empresas signatárias haviam firmado com a inciativa, configurando um erro grotesco e uma lacuna que precisava ser preeenchida. Pensando nisso, foi estabelecido o programa COP - Comunicação de Progresso no Pacto (Communication on Progress). O Programa é considerado a ferramenta mais importante de comunicação e afirmação do compromisso da empresa com os princípios do Pacto Global. As COP correspondem às ações realizadas pelas empresas signatárias do Pacto, e fazem parte dos relatórios e informativos que são enviados anualmente para a ONU. O objetivo da COP é garantir o compromisso das empresas com o Pacto e manter a integridade da iniciativa, criando a avaliação e o aprimoramento contínuo em relação aos dez princípios adotados. É possível conhecer a lista das empresas notáveis acessando o site do Pacto Global ${ }^{203}$. Figuram nesta lista cerca de 342 empresas mundiais.

Para que a empresa possa ser considerada "notável", deve cumprir os requisitos básicos, que segundo o COP são: declaração de apoio contínuo ao Pacto,

\footnotetext{
${ }^{203}$ A lista de empresas notáveis, segundo a iniciativa, são empresas que realizaram as metas ou estão implantando políticas para cumprir os princípios do Pacto. Disponível em: <http://www.unglobalcompact.org/COP/notable_cops.html>.Acesso em: 29.02.2009.
} 
descrição das medidas práticas adotadas na aplicação dos princípios do Pacto Global e/ou a realização de projetos de colaboração e apoio aos objetivos das Nações Unidas, medição de resultados e a apresentação de informes que possam garantir a transparência, a oportunidade de informação, incluindo o diálogo entre os interessados.

De acordo com esses critérios estabelecidos, a auto-avaliação que as empresas participantes do Pacto realizam, é um instrumento poderoso à disposição da gestão empresarial, já que a sua correta e eficiente utilização constitui um grande desafio para medir os graus de eficiência e de eficácia dessas ações e efetuar as correções, mesmo no curso dos processos. Como, necessariamente, a avaliação está afeta aos princípios do Pacto Global e da sociedade como um todo, o grau de envolvimento desta, determina os níveis de compreensão do processo, de validade, de aceitação e de legitimação alcançados.

A Rede Espanhola apresentou mais de 250 informes de progresso para o ano de 2008, segundo a página da web da rede e isto, significa um aumento de mais de $21 \%$ em relação ao ano anterior. Destacamos ainda que, se produziu uma melhora nos diagnósticos dos princípios de Direitos Humanos e mais de $60 \%$ das pequenas e médias empresas declararam que tem políticas definidas a respeito. Em relação as normas laborais, quase $50 \%$ das ações implantadas pelas grandes empresas se referem aos planos de igualdade. Em contrapartida, as pequenas e médias empresas consideram o princípio relativo ao meio ambiente como um fator de risco (80\% do total). E o princípio da luta contra a corrupção, extorção e propina é o que tem apresentado menos mecanismos de seguimento. 
Mais adiante, dissertaremos de forma detalhada a respeito do processo de avaliação das empresas, porque consideramos ser um instrumento fundamental para a melhoria dos processos de gestão.

\subsubsection{As Normas de Direitos Humanos para as Empresas das Nações}

\section{Unidas}

Ao reconhecer que a mundialização econômica também se estende as empresas, os defensores dos Direitos Humanos tem lutado para que elas, assim como os outros agentes de igual importância, sejam incluídos nas regras internacionais de Direitos Humanos. Nos tempos em que se produz uma intensa atividade no comércio internacional e nas instituições financeiras, o poder desses agentes econômicos gera uma enorme influência na política, que repercute nos Direitos Humanos. A Declaração Universal dos Direitos Humanos descreve que "tanto os indivíduos quanto as instituições" devem promover o respeito aos Direitos Humanos, e assegurar seu reconhecimento e aplicação. Ora, se as atividades comerciais proporcionam trabalho a milhões de pessoas, essas atividades que se aplicam diariamente no mundo, podem ter efeitos negativos em relação aos Direitos Humanos. É possível que, essas empresas possam violar os Direitos Humanos de seus trabalhadores, das comunidades locais e a preservação do meio ambiente.

As normas da ONU para as empresas estão compiladas em uma Declaração ou uma lista de obrigações empresariais na esfera dos Direitos Humanos. Elas servem de referência útil e eficaz para avaliar as obrigações nacionais e também, de referência para as Organizações Não Governamentais (ONGs) e para os ativistas em Direitos Humanos. Foram adotadas pela Subcomissão da ONU para a Promoção e Proteção dos Direitos Humanos. A Subcomissão produziu diversos documentos a 
respeito dos Direitos Humanos, desenvolvendo tratados e ampliando-os. Em 1997 a mesma Subcomissão, realizou um estudo sobre as empresas transnacionais e os Direitos Humanos, e, em 1999, começou o projeto de elaboração de um Código de Conduta para as empresas com a participação das partes interessadas no assunto. A discussão envolveu empresas, sindicatos, organizações de defesa dos Direitos Humanos e ONGs.

Segundo o documento "Las Normas de Derechos Humanos de la ONU para Empresas: hacia la responsabilidad legal ${ }^{204,,}$ as regras aí colocadas geram efeitos legais por vários motivos. Primeiro, porque o Direito Internacional não é estático, está em constante desenvolvimento. Segundo, porque as normas da ONU são diferentes dos Códigos de Conduta das empresas já que são normas formais, consideradas como parte do Direito Internacional Costumeiro. E, por último, geram efeitos legais porque, suas disposições foram extraídas de normas internacionais já existentes e válidas, como a Declaração Universal dos Direitos Humanos.

Essas normas são enunciados de princípios típicos de normas previstas no Direito Internacional como soft law. Essa expressão, é uma fórmula de regulamentação internacional que dá ênfase aos princípios e enunciados mais gerais e não deve ter conotação negativa. Ao contrário dos que entendem que soft law parece criar uma responsabilidade soft, a realidade é que essas Normas obrigam o suficiente, porque, o que está em jogo é a concorrência, a imagem da empresa perante consumidores e empregados, sindicatos e ONGs que podem fiscalizar o compromisso que foi enunciado pelas empresas ${ }^{205}$. Por isso, acreditamos que as Normas de Direitos

\footnotetext{
${ }^{204}$ Publicado originalmente em 2004 por: Amnesty International Publications Secretariado Internacional Peter Benenson House 1 Easton Street Londres WC1X 0DW Reino Unido. Disponível em <http://www.amnesty.org/es/library/info/IOR42/002/2004>. Acesso em 01.02.2009.

${ }^{205}$ BARZOTTO, Luciane Cardoso. Códigos de Conduta, Responsabilidade Empresarial e Direitos Humanos dos Trabalhadores. Revista LTr. Legislação do Trabalho, São Paulo, v. 67, n. 08, (pp. 917929), 2003.
} 
Humanos para as empresas, ultrapassam a obrigação de caráter moral apenas, porque são vinculativas e obrigatórias para a sobrevivência da empresa no contexto atual.

É importante destacar que, as normas da ONU de Direitos Humanos para as empresas, devem ser aplicadas dentro dos limites da esfera de atividade e influência das empresas comerciais. Assim, as normas exigem que elas "promovam, asseguram, respeitem, e façam respeitar e proteger os Direitos Humanos consagrados no Direito Internacional e na legislação nacional dos Estados onde estão inseridas." Com isso, as empresas não devem realizar atividades que violem direta ou indiretamente os Direitos Humanos já proclamados. As Normas invocam diversas leis e regras que as empresas devem reconhecer e respeitar, não somente as normas internacionais aplicáveis ou leis e regulamentos nacionais mas, também, noções mais abstratas como a do "Estado de Direito, do interesse público ou dos objetivos para o desenvolvimento e as políticas sociais, econômicas e culturais", incluídas na transparência, na responsabilidade e na proibição da corrupção.

Cabe lembrar, que essas normas são aplicáveis às empresas que exercem suas atividades em mais de um país, as denominadas empresas transnacionais e as empresas comerciais, que tenham algum tipo de relação com uma empresa transnacional. Caso essas empresas estejam inseridas em países onde os Direitos Humanos ainda não foram reconhecidos, elas devem impulsionar e difundir as Normas da ONU, respeitando a diversidade e as leis daquele país.

O princípios e obrigações enunciados na Carta das Nações Unidas ${ }^{206}$ para as empresas, em particular nos artigos $1^{\circ}$ e $2^{\circ}$, são seguintes:

\footnotetext{
${ }^{206}$ Carta das Nações Unidas. Op. Cit. Nota 107.
} 


\section{As obrigações:}

1) "Manter a paz e a segurança internacionais e, para esse fim, tomar medidas coletivas eficazes para prevenir e afastar ameaças à paz e reprimir os atos de agressão, ou outra qualquer ruptura da paz e chegar, por meios pacíficos, e em conformidade com os princípios da justiça e do Direito nternacional, a um ajustamento ou solução das controvérsias ou situações internacionais que possam levar a uma perturbação da paz;

2) Desenvolver relações de amizade entre as nações baseadas no respeito do princípio da igualdade de direitos e da autodeterminação dos povos, e tomar outras medidas apropriadas ao fortalecimento da paz universal;

3) Realizar a cooperação internacional, resolvendo os problemas internacionais de carácter econômico, social, cultural ou humanitário, promovendo e estimulando o respeito pelos direitos do homem e pelas liberdades fundamentais para todos, sem distinção de raça, sexo, língua ou religião;

4) Ser um centro destinado a harmonizar a ação das nações para a consecução desses objetivos comuns.

\section{Os princípios:}

1) A Organização é baseada no princípio da igualdade soberana de todos os seus membros;

2) Os membros da Organização, a fim de assegurarem a todos em geral os direitos e vantagens resultantes da sua qualidade de membros, deverão cumprir de boa fé as obrigações por eles assumidas em conformidade com a presente Carta; 
3) Os membros da Organização deverão resolver as suas controvérsias internacionais por meios pacíficos, de modo que a paz e a segurança internacionais, bem como a justiça, não sejam ameaçadas;

4) Os membros deverão abster-se nas suas relações internacionais de recorrer à ameaça ou ao uso da força, quer seja contra a integridade territorial ou a independência política de um Estado, quer seja de qualquer outro modo incompatível com os objetivos das Nações Unidas;

5) Os membros da Organização dar-lhe-ão toda a assistência em qualquer ação que ela empreender em conformidade com a presente Carta e abster-se-ão de dar assistência a qualquer Estado, contra o qual ela agir de modo preventivo ou coercitivo;

6) A Organização fará com que os Estados que não são membros das Nações Unidas ajam de acordo com esses princípios em tudo quanto for necessário à manutenção da paz e da segurança internacionais;

7) Nenhuma disposição da presente Carta autorizará as Nações Unidas a intervir em assuntos que dependam essencialmente da jurisdição interna de qualquer Estado, ou obrigará os membros a submeterem tais assuntos a uma solução, nos termos da presente Carta; este princípio, porém, não prejudicará a aplicação das medidas coercitivas constantes do capítulo VII.

Ainda, em consonância com os artigos 55 e 56, sobre a Cooperação Econômica e Social Internacional, que tem o fim de criar condições de estabilidade e bem-estar necessárias às relações pacíficas e amistosas entre as Nações, baseadas no respeito ao princípio da igualdade de direitos e da autodeterminação dos povos, as Nações Unidas estão incumbindo as empresas a promoverem: 
- $\quad$ A elevação dos níveis de vida, o pleno emprego e condições de progresso e desenvolvimento econômico e social;

- A solução dos problemas internacionais econômicos, sociais, de saúde e conexos, bem como, a cooperação internacional, de caráter cultural e educacional;

- $\quad$ O respeito universal e efetivo dos direitos do homem e das liberdades fundamentais para todos, sem distinção de raça, sexo, língua ou religião.

Para a realização dos objetivos enumerados no artigo 55, todos os membros da Organização se comprometem a agir em cooperação com esta, em conjunto ou separadamente. Entre os artigos enumerados, a ONU também objetiva promover o respeito universal e a observância dos Direitos Humanos e as liberdades fundamentais das pessoas. Cabe lembrar que, a Declaração Universal dos Direitos Humanos, constitui um ideal comum para que todas as nações se esforcem e para que os governos, as instituições e os indivíduos, promovam, mediante o ensino e a educação, o respeito aos Direitos Humanos e as liberdades, assegurando, inclusive, a igualdade de direitos e a promoção do progresso social e a elevação do nível de vida.

Nesse sentido, os Estados tem a responsabilidade de promover e respeitar os Direitos Humanos, fazendo com que eles se efetivem. As empresas transnacionais e outras empresas comerciais, em seu papel de órgãos da sociedade, também devem ter a responsabilidade de promover, de cumprir e de assegurar tais direitos enunciados na Declaração Universal de Direitos Humanos. As empresas, seus dirigentes, trabalhadores e partes interessadas, além de terem o dever de respeitar as normas de Direitos Humanos para as empresas da ONU, devem levar em conta, outros princípios e normas reconhecidos que trazem os Tratados das Nações Unidas e os instrumentos 
internacionais como a Declaração Universal dos Direitos Humanos (1948), além dos Tratados Internacionais de Direitos Humanos que contêm normas internacionalmente reconhecidas para as empresas. Dentre eles, podemos destacar: o Pacto Internacional de Direitos Civis e Políticos (1966); a Convenção Internacional sobre a Eliminaçäo de todas as formas de Discriminação Racial (1966); a Convenção sobre a eliminação de todas as formas de Discriminação contra a Mulher (1979); a Convenção sobre a Tortura e outros tratos e penas cruéis, desumanos e degradantes (1984); a Convenção sobre os direitos da Criança (1989); o Pacto Internacional de Direitos Econômicos, Sociais e Culturais (1966) ${ }^{207}$.

As empresas transnacionais e outras empresas comerciais, também deverão respeitar o conteúdos dos Tratados regionais de Direitos Humanos que contenham normas internacionalmente reconhecidas, e as Convenções, os princípios e os Códigos internacionais específicos sobre a matéria. Levando em conta as tendências mundiais de influência das empresas transnacionais e comerciais nas economias dos países e as relações econômicas internacionais, essas empresas, tem a capacidade de promover o bem estar econômico, o desenvolvimento, os avanços tecnológicos, ou causar prejuízos aos Direitos Humanos e à vida das pessoas.

Considerando que os Direitos Humanos incluem em seu rol o direito ao desenvolvimento e que, todos os povos tem direito de participar do desenvolvimento econômico, social, cultural e político, as disposições chave das Normas de Direitos Humanos da ONU para as empresas envolvem ${ }^{208}$ :

\footnotetext{
${ }^{207}$ Esses Documentos podem ser encontrados na página da Organização das Nações Unidas, Instrumentos Internacionais, disponível em: <http://www2.ohchr.org/spanish/law/index.htm>. Acesso em 11.02.2009. ${ }^{208}$ Op.Cit. Nota 204.
} 
- Obrigações gerais: Partindo do pressuposto de que os Estados tem a obrigação de promover e proteger os Direitos Humanos consagrados na legislação internacional e nacional, inclusive, fazendo com que as empresas respeitem esses direitos dentro do ramo de suas atividades nos países nos quais exercem suas atividades, assegurando que essas atividades não contribuam direta ou indiretamente em causar prejuízos aos seres humanos. As empresas devem tomar conhecimento a respeito dos Direitos Humanos e sobre as consequências resultantes da sua violação;

\section{- $\quad$ Direito à igualdade de oportunidade e a um tratamento não}

discriminatório: As empresas transnacionais e outras empresas comerciais devem garantir a igualdade de oportunidade, a fim de eliminar toda e qualquer discriminação por motivo de raça, cor, sexo, idioma, religião, opinião política, origem nacional ou social, condição social, por pertencer a um povo indígena, idade (exceto os menores de idade).

Sendo assim, o princípio das normas da ONU para as empresas, fundamenta-se em Documentos consagrados internacionalmente e pede para que as Instituições garantam a igualdade de oportunidades eliminando toda e qualquer forma de discriminação por condições físicas, orientação sexual, raça ou religião. Ainda requer que, as Instituições cuidem para que nenhum trabalhador seja objeto de qualquer forma de discriminação física, psicológica, verbal ou qualquer forma de assédio ou maltrato.

As empresas deverão respeitar também, leis nacionais referentes a esse princípio. Vale destacar novamente a LOIMH 003/2007 da Espanha de 22 de março para la igualdad efectiva de mujeres y hombres. Essa lei tem por objetivo fazer valer a igualdade de tratamento e oportunidades entre mulheres e homens, em especial, a não discriminação contra a mulher, seja qual for a situação ou circunstância em que se 
encontre. Estabelece ainda, princípios para a atuação dos Poderes Públicos, regulando os direitos das pessoas físicas e jurídicas, tanto públicas como privadas, prevendo medidas para eliminar e corrigir toda e qualquer forma de discriminação por razão de sexo. Ademais, a Lei de Igualdade espanhola traz o plano de igualdade para a empresas e outras medidas de promoção e igualdade, corroborando assim, para que as empresas atentem para as estratégias em seu âmbito de gestão, na elaboração e aplicação efetiva desse importante princípio do direito à igualdade de oportunidade e a um tratamento não discriminatório da ONU.

- Direito à segurança pessoal: As empresas transnacionais e outras empresas nacionais não cometerão atos que contribuam ou constituam crimes de guerra, crimes contra a humanidade, genocídio, tortura, trabalhos forçosos ou obrigatórios, tomadas de reféns, execuções sumárias ou arbitrárias, violações de direito humanitário ou delitos internacionais de outra índole contra a pessoa humana, segundo se define no Direito Internacional, em particular, nas normas de Direitos Humanos e em Direito Humanitário.

Nesse sentido, a segurança pessoal que hoje é um dos componentes mais relevantes para uma reflexão de ordem mundial, revela que, devemos atentar para os vários tipos de violência a que estamos expostos. Dentre elas destacam-se as ameaças do Estado (tortura física), ameaças de outros Estados (guerra), ameaças de grupos da população (tensão étnica), ameaças de indivíduos ou grupos contra outros indivíduos ou grupos (delinquência, violência), ameaças contra as mulheres (violação,violência doméstica) e as ameaças contra as crianças a respeito de sua vulnerabilidade e de sua dependência. 
A segurança das pessoas é atacada em todas as partes do mundo, e apresenta-se na forma de degradação social, de terrorismo, de contaminação e do tráfico de drogas nas fronteiras. Tanto os países pobres como os ricos estão em risco pelas crescentes angústias e medos, pelo o aumento da delinquência, do crime, da insegurança pessoal e o crescente isolamento individual das pessoas. As empresas devem estabelecer políticas de não contratação de pessoas ou grupos paramilitares ou empresas de serviços de segurança que tenham sido responsáveis por violarem os Direitos Humanos e o Direito Internacional Humanitário.

Cabe destacar, que o conceito de segurança humana apareceu pela primeira vez em $1994 \mathrm{em}$ um dos informes que realiza anualmente o PNUD ${ }^{209}$. O programa, levou à necessidade de uma análise global sobre o tema e definiu segurança humana. Para o PNDU, as condições que garantem a segurança humana são: um povo livre do medo e livre de carências.

Segundo FERNÁNDEZ PEREIRA ${ }^{210}$, de todos os informes das Nações Unidas, esse é o mais significativo para conhecer sobre o tema da segurança humana. $\mathrm{O}$ Documento, marcou o início de um debate e reflexão mundial a respeito do conceito e das dimensões sobre a segurança humana. Nesse sentido há uma comissão independente sobre segurança humana nas Nações Unidas, que foi inaugurada em 2000 na Cúpula do Milênio. Essa comissão, foi convocada para elaborar o Documento intitulado "A Segurança Humana Agora." O objetivo desse Documento é servir de guia para que os investigadores, as instituições e os governos conheçam o tema para incluí-lo em seus

\footnotetext{
${ }^{209}$ O Programa das Nações Unidas para o Desenvolvimento (PNUD) é a rede global de desenvolvimento da Organização das Nações Unidas, presente em 166 países. Seu mandato central é o combate à pobreza. Trabalhando ao lado de governos, iniciativa privada e sociedade civil, o PNUD conecta países a conhecimentos, experiências e recursos, ajudando pessoas a construir uma vida digna e trabalhando conjuntamente nas soluções traçadas pelos países-membros para fortalecer capacidades locais e proporcionar acesso a seus recursos humanos, técnicos e financeiros, à cooperação externa e à sua ampla rede de parceiros. Disponível em: 〈http://www.pnud.org.br/pnud/>.

${ }^{210}$ FERNÁNDEZ PEREIRA, Juan Pablo. La Seguridad Humana...Op. Cit. Nota 149, (p.65).
} 
programas no âmbito local, nacional e internacional. Para a Comissão ${ }^{211}$, a definição de segurança humana consiste em,

la seguridad humana consiste en proteger la esencia vital de todas las vidas humanas de una forma que realce las libertades humanas y la plena realización del ser humano. Seguridad humana significa proteger las libertades fundamentales: libertades que constituyen la esencia de la vida. Significa proteger al ser humano contra las situaciones y las amenazas criticas (graves) y omnipresentes (generalizadas). Significa utilizar procesos que se basan en la fortaleza y las aspiraciones del ser humano. Significa la creación de sistemas políticos, sociales, medioambientales, económicos, militares y culturales que en su conjunto brinden al ser humano las piedras angulares de la supervivencia, los medios de vida y la dignidad.

- Direito dos trabalhadores: As empresas transnacionais e outras empresas nacionais não recorrerão ao trabalho forçoso ou obrigatório proibido nos instrumentos internacionais e na legislação nacional pertinentes, assim como as normas internacionais de Direitos Humanos e o Direito Internacional Humanitário.

Como vimos no item anterior, em muitos países do mundo, a eliminação do trabalho forçado é um grande desafio desse século. Em alguns países, os trabalhadores domésticos estão à mercê de seus empregadores, e também, em alguns Estados, existem trabalhadores que são obrigados a auxiliarem grupos militares rebeldes. Ainda há a escravidão por dívida e a exploração de mulheres e crianças por meio da prostituição.

Portanto, os Direitos Humanos dos trabalhadores, como norma da ONU para as empresas estão em consonância os Convênios relativos ao Trabalho Forçado ou

\footnotetext{
${ }^{211}$ Comisión para la Seguridad Humana (2003): La Seguridad Humana Ahora. Informe final. MultiLanguage Services Inc, Nueva York, (pp.10-12).
} 
Obrigatório de 1930 (n² 29) e no Convênio relativo a Abolição do Trabalho Forçado de 1957 ( $\mathrm{n}^{\circ}$ 105) da OIT e outros instrumentos internacionais de Direitos Humanos ${ }^{212}$.

\section{- $\quad$ Respeito à soberania nacional e dos Direitos Humanos: As}

empresas transnacionais e as empresas nacionais observarão e respeitarão as normas aplicáveis do Direito Internacional, as leis, os regulamentos nacionais, assim como as práticas administrativas, o estado de direito, o interesse público, os objetivos do desenvolvimento, as políticas sociais, econômicas e culturais, incluída a transparência, a responsabilidade e a proibição da corrupção e a autoridade dos países em que realizam suas atividades.

Nesse sentido, as empresas signatárias das normas da ONU, deverão respeitar as leis e as Constituições nos países onde realizam suas atividades e negócios, observando o desenvolvimento local e, dentro de suas capacidades, fomentar o progresso social, mediante a implantação de oportunidades econômicas, principalmente nos países em desenvolvimento.

De acordo com TEITELBAUM ${ }^{213}$ o termo desenvolvimento, comporta aspectos jurídicos, políticos, éticos, sociais e culturais. Trata-se de um Direito Humano fundamental, que tem por finalidade a plena realização do ser humano como tal, passando pela aceitação do direito ao desenvolvimento pessoal e de certos direitos considerados mínimos para todos. É por esta razão, que o desenvolvimento deve ser um processo global, cujo o sujeito principal é o ser humano e sua realização nos aspectos físico, intelectual, moral e cultural dentro da comunidade em que vive. Dessa forma, as

\footnotetext{
${ }^{212}$ Ver mais sobre os Convênios $\mathrm{n}^{\mathrm{o}} 29$ e $\mathrm{n}^{\mathrm{o}} 105$ da OIT descritos e suas ratificações. Disponível $<$ http://www.ilo.org/global/What_we_do/InternationalLabourStandards/Subjects/Forcedlabour/lang-s/index.htm>. Acesso em 09.02.2009.

${ }^{213}$ TEITELBAUM, Alejandro; ETXEBERRIA, Xabier; NAVARRO, Emilio. Ética y Derechos Humanos en la Cooperación Internacional. Instituto de Derechos Humanos. Cuaderno Deusto de Derechos Humanos, Bilbao, 2002.
} 
empresas deverão observar a Declaração sobre o Direito ao Desenvolvimento aprovada pela Assembleia Geral da ONU em 1986 e o Convênio sobre os Povos Indígenas e Tribais de $1989\left(\mathrm{n}^{\mathrm{o}} 169\right)^{214}$.

\section{- Obrigações em matéria de proteção do consumidor: As} empresas transnacionais e as empresas nacionais atuarão em consonância com as práticas comerciais e publicitárias leais e adotarão quantas medidas forem necessárias para garantir a segurança e a qualidade dos bens e serviços que proporcionam, inclusive, observando o princípio da precaução. Não produzirão, distribuirão, comercializarão nem proporcionarão produtos danosos ou potencialmente danosos para o uso dos consumidores.

Em relação à segurança e a qualidade dos produtos que as empresas comercializam, nos reportamos ao termo "segurança alimentar", que significa que todos devem ter acesso a uma alimentação básica e saudável. Nesse aspecto, nos países em desenvolvimento, a segurança alimentária diz respeito as ações capazes de evitar intoxicações e doenças causadas pela má alimentação ou pela alimentação incorreta.

As possíveis ameaças à segurança alimentar são o aumento da insalubridade, a propagação de epidemias e a deterioração do sistema sanitário. Já se sabe que, nos países em desenvolvimento, as doenças contagiosas e parasitárias matam 17 milhões de pessoas por ano.

Assim, as empresas observarão as normas internacionais pertinentes para à proteção dos consumidores e as diretrizes para a proteção do consumidor e as normas internacionais pertinentes à promoção de produtos específicos, como por exemplo, as

\footnotetext{
${ }^{214}$ Op.Cit. Nota 204.
} 
que rezam o Código Internacional de Comercialização dos Substitutos do Leite Materno, aprovado pela Assembléia Mundial da Saúde. Também, velarão para que seus produtos sejam devidamente armazenados e comercializados de forma transparente e segura aos consumidores.

- Obrigações em matéria de proteção ao meio ambiente: As empresas transnacionais e as empresas nacionais realizarão suas atividades em conformidade com as leis, os regulamentos, as práticas administrativas e as políticas nacionais relativos à conservação do meio ambiente nos países em que realizam suas atividades, assim como, agirão em conformidade com os acordos, princípios, objetivos, responsabilidades e normas internacionais pertinentes relacionadas com o meio ambiente e os Direitos Humanos, a saúde pública e a segurança, a bioética e o princípio de precaução, e, em geral, realizarão suas atividades de forma que contribuam aos objetivos mais amplos de desenvolvimento sustentável.

Nesse sentido, a responsabilidade socioambiental diz respeito à preocupação das empresas com as implicações de suas práticas empresariais e atividades de negócios dentro da comunidade. É necessário incorporar, em suas estratégias de gestão, mecanismos que gerem resultados positivos para as partes interessadas e que não comprometam ou degradem o meio ambiente. Portanto, a empresa socio-ambientalmente responsável, é aquela que visa a sustentabilidade de sua atuação, através de práticas economicamente viáveis, socialmente justas e culturalmente aceitas.

Ademais, as atividades realizadas pelas empresas signatárias das normas de Direitos Humanos da ONU, diz que elas deverão agir em conformidade com as leis, os regulamentos e as políticas nacionais relativas a conservação do meio ambiente nos 
países onde estiverem inseridas. Deverão observar também, as normas internacionais em relação aos Direitos Humanos e ao meio ambiente saudável, a saúde pública, e a segurança, agindo em conformidade com o desenvolvimento sustentável. A primeira medida que as empresas devem adotar é a de aprovar, difundir e aplicar as normas acima mencionadas e, consequentemente, agirem para garantir a incorporação dessas normas em seus contratos ou acordos com as partes interessadas em seus negócios e transações comerciais.

Os governos, por sua vez, deverão aplicar e supervisionar a utilização das presentes normas, difundindo-as e utilizando-as como modelo de legislação ou de disposições administrativas em relação as atividades de cada empresa. Isso pode ser feito, por meio de inspeções no trabalho, da exigência para que participem de processos licitatórios ou em negócios com o Estado. Dessa forma, participariam de negócios com o Estado, apenas as empresas que estivessem agindo em consonância com essas regras. Assim, o poder público estaria contribuindo para que as normas de Direitos Humanos da ONU para as empresas, passassem do plano teórico para a prática. Para finalizar esse item, utilizaremos MARTÍN ORTEGA ${ }^{215}$, que pontua,

(...) las normas son un importante esfuerzo por definir la responsabilidad de las empresas en materia de derechos humanos, y sobre todo por enraizarlas en el Derecho Internacional público e alejarlas de la buena voluntad corporativa. Ponen, de manifiesto, además de la potencialidad del Derecho Internacional para abrir su alcance a la responsabilidad de otras entidades por violaciones de derechos humanos, la habilidad de la doctrina internacionalista para crear los instrumentos y mecanismos jurídicos que lo hagan posible (...) han abierto la posibilidad de ser imaginativos, buscar más allá do lo que parece obvio y de mirar detrás de puertas que en Derecho Internacional que parecían firmemente selladas.

\footnotetext{
${ }^{215}$ MARTÍN ORTEGA. Olga. Empresas Multinacionales (...). Op. Cit Nota 165, (p.193).
} 
Entretanto, é importante destacar que, a proposta é que cada uma das empresas envolvidas nesse processo, faça uma avaliação periódica para verificar o cumprimento das normas. Se a avaliação apresentar lacunas ou falhas, as empresas deverão incluir planos de ações e métodos de reparação, proporcionando as compensações ou indenizações às pessoas, entidades e comunidades que tenham sido prejudicadas.

\subsection{As Iniciativas da Sociedade Civil}

\section{Global Reporting Initiative (GRI)}

O Global Reporting Initiative apresenta Diretrizes para a padronização de relatórios de sustentabilidade e surgiu em 1997 em parceria com a Coalizão para Economias Ambientalmente Responsáveis (CERES) e o Programa das Nações Unidas para o Meio Ambiente. A principal proposta é desenvolver Diretrizes para a elaboração de relatórios de sustentabilidade, sendo uma ampla rede multistakeholder composta por especialistas de vários países em todo o mundo.

A tendência é que as empresas adotem como padrão os relatórios propostos pela GRI. A elaboração de relatórios de sustentabilidade é um processo para a divulgação pública do desempenho econômico, ambiental e social de uma organização. Muitas empresas percebem que, apenas o relatório financeiro já não satisfaz as necessidades dos stakeholders e que a busca pelas informações de uma empresa agora são a nível global. O termo "Relatório de Sustentabilidade" é sinônimo de relatório 
social, baseado no triple bottom line $e^{216}$ e outros termos que englobam os aspectos econômicos, ambientais e sociais do desempenho de uma Organização.

A GRI supõe que os relatórios apresentados pelas empresas sigam alguns princípios como: a transparência, a inclusão (elaboradas em conjunto com as partes interessadas), a comparabilidade, a integridade, a relevância e a exatidão, entre outros. O relatório de sustentabilidade é um processo e uma ferramenta vivos, que não se inicia nem termina com uma publicação impressa ou on-line. Sua elaboração deverá se estabelecer em um processo mais amplo de estratégia organizacional e a implementação de planos de ação e avaliação de resultados. O relatório possibilita uma sólida avaliação do desempenho da Organização e pode dar suporte à melhoria contínua do desempenho ao longo do tempo ${ }^{217}$.

No que refere à avaliação dos resultados é importante salientar que, a empresa pode realizar também a auto-avaliação dos seus processos de gestão, perfazendo assim, uma revisão e uma autocrítica naquelas estratégias ou indicadores que, por algum motivo, não saíram como o planejado. Complementando aí a Comunicação de Progresso do Pacto Global ${ }^{218}$, uma vez que tenta transformar seus princípios e objetivos em algo palpável para que todos possam conhecê-los e avaliá-los.

Entre os indicadores de desempenho do GRI estão a seguintes categorias: as práticas de emprego e trabalho decente (emprego, relações trabalho/gestão, saúde e segurança, treinamento e educação, diversidade e oportunidade) e Direitos Humanos

\footnotetext{
${ }^{216}$ Triple bottom line, em português quer dizer linha de função tripla. São os resultados de uma empresa medidos em termos sociais, ambientais e econômicos. São apresentados nos relatórios corporativos das empresas. Seria o tripé da sustentabilidade que embasa todas as práticas de desenvolvimento sustentável.

${ }^{217}$ Diretrizes para o Relatório de sustentabilidade. Disponível em:<http://www.globalreporting.org> Acesso em 11.02.2010.

${ }^{218}$ Vimos sobre o assunto no item 3.3.2. O Pacto Global da ONU para as empresas.
} 
(estratégia e gestão, não-discriminação, liberdade de associação e negociação coletiva, trabalho infantil, trabalho forçado, práticas de seguridade e direitos indígenas).

Segundo os últimos dados divulgados no site da GRI, o número de empresas e organizações que divulgam seu desempenho publicamente através dos relatórios utilizando os indicadores de sustentabilidade aumentou muito neste último ano. Já são mais de mil organizações no mundo que produzem tais relatórios com base na versão da GRI. A iniciativa acrescenta ainda, que, a maior parte dos relatórios produzidos provém da Espanha, mais que os EUA, que aparecem em segundo lugar. A Europa concentra $49 \%$ das organizações relatoras e a América Latina concentra $12 \%{ }^{219}$. Atualmente no Brasil, são 60 empresas que realizam relatórios de sustentabilidade seguindo o modelo da GRI e conta com a parceria do Instituto Ethos.

\section{O Balanço Social do Instituto Brasileiro de Análises Sociais e}

\section{Econômicas (IBASE)}

O Instituto Brasileiro de Análises Sociais e Econômicas (IBASE) surgiu em 1981 como uma instituição sem fins lucrativos e com o intuito de aprofundar a construção da democracia, combatendo as desigualdades sociais e estimulando a participação cidadã. Sua relação com as empresas é baseada nos relatórios de sustentabilidade - O Balanço Social do IBASE, que visa dar transparência as atividades das empresas por meio da divulgação dos relatórios e ampliar o diálogo com a sociedade. Ademais, é uma ferramenta de gestão excelente para que a empresa avalie seu nível de responsabilidade social.

\footnotetext{
${ }^{219}$ Fonte fornecida pelo site da GRI versão em português. Disponível em: <http://www.globalreporting.org/NewsEventsPress/LatestPressReleases/2009/Pressrelease_15_Jul_2009_ PT.htm>. Acesso em 11.02.2010.
} 
Em 1997 foi lançado pelo sociólogo brasileiro Herbert de Souza ${ }^{220}$ uma campanha para que as empresas divulgassem suas atividades. O Sociólogo afirmava que realizar o balanço social significava fazer uma grande contribuição para consolidação de uma sociedade verdadeiramente democrática. Segundo o IBASE as empresas devem realizar os relatórios de sustentabilidade primeiro, porque é ético, agrega valor, traz um diferencial para a imagem da empresa, sendo cada vez mais valorizado pela sociedade e pelos investidores. E depois, porque é um moderno instrumento de gestão, que gera, mede e divulga o exercício da responsabilidade social da organização. Ademais, o balanço social é um instrumento de avaliação porque os analistas de mercado, investidores e órgãos de financiamento como o Banco Nacional de Desenvolvimento Econômico e Social (BNDES), o Banco Interamericano de Desenvolvimento (BID) e a International Finance Corporation (IFC) incluem o Balanço Social na lista de documentos necessários para se conhecer e avaliar os riscos de uma empresa ${ }^{221}$.

Os itens de verificação que as empresas devem fornecer ao apresentarem seus relatórios do Balanço Social são: educação, saúde, atenção à mulher, atuação na preservação do meio ambiente, melhoria da qualidade de vida de trabalho dos

\footnotetext{
${ }^{220}$ Herbert de Souza, conhecido como "Betinho", foi um ativista dos Direitos Humanos no Brasil, dedicou-se a projetos como a "Ação da Cidadania Contra a Fome, a Miséria e pela Vida". Em 1998, para estimular a participação de um maior número de empresas, o Ibase lançou o Selo Balanço Social Ibase/Betinho. Através deste Selo as empresas podem mostrar em seus anúncios, embalagens, sites e campanhas publicitárias que investem em educação, saúde, cultura, esportes e meio ambiente. O Selo Balanço Social Ibase/Betinho, segundo o Instituto, demonstra que a empresa já deu o primeiro passo para tornar-se uma verdadeira empresa-cidadã, comprometida com a qualidade de vida dos funcionários, da comunidade e do meio ambiente. Apresentando publicamente seus investimentos internos e externos através da divulgação anual do seu balanço social. Informações retiradas do site: <http://www.ibase.org.br/>. Acesso em 18.02.2010. Não foi encontrado no site do instituto ou em outra fonte o número exato de empresas brasileiras que já participaram ou publicaram seus relatórios.

${ }^{221}$ O BNDES é um órgão do Governo Federal, o principal instrumento de financiamento de longo prazo para a realização de investimentos em todos os segmentos da economia, em uma política que inclui as dimensões social, regional e ambiental. Foi fundado em 1952, se destaca no apoio à agricultura, indústria, infraestrutura e comércio e serviços, oferecendo condições especiais para micro, pequenas e médias empresas. Fonte: $<\mathrm{http} / / /$ www.bndes.gov.br. O BID fundado em 1959 para apoiar o processo de desenvolvimento econômico e social da América Latina e Caribe, é a principal fonte de financiamento multilateral na região. Fonte: http://www.iadb.org. A IFC concede empréstimos, capital, produtos para a gestão de riscos e financiamento estruturado e serviços de consultoria para o desenvolvimento do setor privado nos países em desenvolvimento. Fonte:< http://www.ifc.org/about. Acesso em 20.02.2010.
} 
funcionários e apoio à projetos comunitários, com o objetivo de erradicar a pobreza, geração de renda e novos postos de trabalho.

\section{O Modelo Europeu de Gestão de Qualidade (EFQM)}

A fundação Européia para a Gestão da Qualidade Total, foi criada em 1988 por importantes empresas européias, com o patrocínio da Comissão Européia. Instituiu o Prêmio Europeu de Qualidade Total em 1991 e atualmente conta com mais de 800 empresas, incluindo multinacionais, empresas do setor público e pequenas e médias empresas. Em 1993, a fundação incorpora dois tipos de reconhecimentos: O Prêmio Europeu de Qualidade (European Quality Prize) para empresas que demonstram excelência na gestão, sendo reconhecidas no mercado como "excelentes", e o Troféu Europeu da Qualidade (European Quality Award) para empresas de maior êxito de gestão da qualidade na Europa. O EFQM é um modelo normativo cuja a ferramenta principal é a auto-avaliação baseada em um diagnóstico a respeito do funcionamento da gestão empresarial. Sua missão é de estimular e ajudar as organizações européias a participar de atividades de melhoria, levando-as à excelência e as satisfação de seus clientes, funcionários e sociedade.

O modelo de excelência da EFQM é uma estrutura não-prescritiva para a compreensão das conexões entre o que a organização faz e os resultados que é capaz de alcançar, utilizada para definir quais as capacidades e os recursos necessários para integrar os objetivos estratégicos da empresa. O modelo envolve os seguintes critérios: liderança, estratégia, pessoas, parcerias e recursos, processos, produtos e serviços, 
resultados de clientes, resultados com as pessoas que integram a empresa e com a sociedade e principais resultados ${ }^{222}$.

Na Espanha a EFQM está representada pela Organización Club Excelencia en Gestión $^{223}$ com sede em Madrid, fundada em 1991, participam organizações públicas e privadas, o objetivo é acelerar a transformação das organizações para que possam competir e se desenvolver em uma economia global, identificando novos rumos, trocando experiências e induzindo modelos de gestão.

\section{Social Accountability 8000, ISO 26000 e OHSAS 18001}

Além das iniciativas que sugerem que as empresas tornem públicos seus indicadores de gestão em relação aos direitos fundamentais do trabalhador e a responsabilidade social através de relatórios, existem aquelas que visam estabelecer padrões de qualidade. A Social Accountability ${ }^{224} 8000$ (SA 8000) foi lançada em 1997 pela Council on Economics Priorities Accreditation Agency (CEPAA), e atualmente, conhecida como Social Accountability International (SAI) ${ }^{225}$. Essa Organização norte americana foi a primeira em certificação internacional no que respeita a responsabilidade social de empresas com alcance global. Seu objetivo principal é garantir os direitos dos trabalhadores. A Norma se apresenta como um sistema de

\footnotetext{
${ }^{222}$ Disponível em: <http://www.efqm.org>. Acesso em 15.06.2010.

${ }^{223}$ Disponível em: <http://www.clubexcelencia.org>. Acesso em 15.06.2010.

${ }^{224}$ Accountability significa transparência, responsabilidade, retorno para as partes interessadas e cumprimento da lei e dos códigos de caráter voluntário. Fonte: ISEA -Institute of Social and Ethical Accountability.

${ }^{225}$ A SAI é uma organização não-governamental norte americana que desenvolveu a norma para as condições laborais e um sistema de verificação independente. A SA 8.000 adota acordos internacionais como as Convenções Internacionais do Trabalho, a Convenção das Nações Unidas pelos Direitos da Criança e a Declaração Universal dos Direitos Humanos. Ela é reconhecida mundialmente como a norma mais aplicável ao ambiente de trabalho, e pode ser auditada em qualquer porte de organização, em qualquer localidade geográfica e setor industrial. Entre as áreas cobertas pela SA 8.000 estão: trabalho infantil, trabalho forçado, saúde e segurança, liberdade de associação e direito a acordos coletivos, discriminação, práticas disciplinares, horas de trabalho, compensação e sistemas de gestão. Estabelecendo padrões que governam os direitos dos trabalhadores.
} 
auditoria similar à ISO $9000^{226}$, com condições baseadas nas Diretrizes internacionais de Direitos Humanos e nas Convenções da OIT.

A SAI afirma que, "nossa missão é promover os direitos humanos dos trabalhadores em todo o mundo como uma organização de padrões éticos", acrescenta ainda que a Norma SA 8000 melhora as condições de trabalho e a produtividade dos negócios $^{227}$. Ela é baseada em instrumentos internacionais de Direitos Humanos e no Direito do Trabalho, amparada pela Declaração Universal dos Direitos Humanos, pela Convenção dos Direitos da Criança e pela Convenção da ONU sobre a Eliminação de Todas as Formas de Discriminação contra a Mulher. Entre as questões abordadas pela Norma estão a segurança e a saúde no âmbito laboral, a discriminação, a liberdade de associação e o direito à negociação coletiva, o trabalho infantil e o trabalho forçado, a carga horária e a jornada de trabalho, os benefícios para os trabalhadores e o sistema de gestão. Para monitorar a utilização da norma SA 8000 pelas empresas, a SAI trabalha com a Social Acoountability Acreditation Service (SAAS), que funciona como um Organismo de certificação que administra e dirige as atividades de acreditação das Organizações.

De acordo com o Instituto Ethos, atualmente, 400 empresas em 40 países são certificadas com a SA 8000. O Brasil já é o terceiro país com o maior número de

\footnotetext{
${ }^{226}$ A expressão ISO9000 (International Organization for Standartization), designa um conjunto de normas técnicas que estabelecem um modelo de gestão de qualidade. É uma organização nãogovernamental fundada em 1947 em Genebra e que hoje opera em 157 países, sua função é promover a normatização de produtos e serviços. As normas ISO nasceram na década de noventa para o mundo da indústria e foi se expandindo para outros setores, como o de serviços. As normas da ISO contribuem para que produtos e serviços se tornem mais seguros e confiáveis, proporcionando aos consumidores maior segurança ao adquiri-los. Ademais, facilita o comércio entre os países. Disponível em: <http://www.iso.org/iso/home.htm>. Acesso em 18.02.2010.

${ }^{227}$ Fonte: http://www.sa-intl.org/. Acesso em 22.02.2010.
} 
empresas certificadas e diversas outras já estão em processo de certificação, de grandes multinacionais à empresas de pequeno porte ${ }^{228}$.

Está sendo elaborada a ISO 26000 e essa iniciativa, será a Norma internacional da Responsabilidade Social, com previsão para ser concluída em 2010. Os responsáveis pela elaboração da Norma são: o Instituto sueco de Normalização Swedish Standards Institute (SIS) e a Associação Brasileira de Normas Técnicas (ABNT) ${ }^{229}$. As delegações nacionais que participam do processo de construção da Norma, apresentamse em categorias - os stakeholders, a saber: trabalhadores, consumidores, indústrias, governo, ONGs, organizações não-governamentais, serviços e suporte. As chamadas organizações D-liaison também participam do processo, são delegações internacionais ou regionais, experientes em temas relativos à responsabilidade social, como a OIT GRI, OMS e o Pacto Global.

É importante salientar, que a Norma traz, em seu escopo teórico, algumas recomendações. Afirma que ela não é um sistema de gestão, não visa e não é apropriada para fins de certificação, não tem a intenção de ser utilizada como norma internacional, diretriz ou recomendação. Acrescenta ainda que, não pretende ser citada como evidência na evolução do Direito Internacional costumeiro. Visa apenas, orientar as Organizações em relação ao tema da responsabilidade social, podendo ser utilizada como parte das políticas públicas que os Estados ou a iniciativa privada implemente.

A minuta da ISO26000 adianta que, abordará temas como: governança organizacional, Direitos Humanos, práticas de trabalho, meio ambiente, práticas justas e

\footnotetext{
${ }^{228}$ Ethos. Op. Cit. Nota 156.

${ }^{229}$ ABNT Fundada em 1940 é o órgão responsável pela normalização técnica no país, fornecendo a base necessária ao desenvolvimento tecnológico brasileiro. É uma entidade privada, sem fins lucrativos. É membro fundador da International Organization for Standardization (ISO), da Comissão Panamericana de Normas Técnicas e da Associação Mercosul de Normalização. Fonte:< http://www.abnt.org.br/>. Acesso em 20.02.2010.
} 
leais de operação, questões relativas ao consumidor e desenvolvimento da comunidade. Em especial, no âmbito dos Direitos Humanos, a Norma contemplará a igualdade de oportunidades, que inclui a diversidade, a não discriminação, a igualdade de gênero, os direitos de maternidade e paternidade, a conciliação entre a vida profissional, familiar e pessoal, os direitos de personalidade, a integração de pessoas com deficiência e com capacidades reduzidas. Contemplará também, os direitos das crianças, dos indígenas, das minorias étnicas e dos trabalhadores imigrantes. No que respeita às práticas laborais, enfatizará o trabalho infantil, o trabalho forçado, a segurança do emprego, a jornada de trabalho, as férias, a proteção social, a liberdade de associação e a negociação coletiva. E ainda, a liberdade sindical, a proteção do direito sindical, as práticas disciplinares, a remuneração, os benefícios pecuniários, a mobilidade profissional (funcional e geográfica) e o assédio sexual e o assédio moral ${ }^{230}$.

A data limite para a publicação oficial da ISO 26000 como norma internacional está prevista para o final de 2010. Até agora, das normas analisadas, a ISO 26000 é a mais bem estruturada em relação aos Direitos Humanos e às práticas laborais e trabalhistas, trazendo como indicador o assédio moral e o assédio sexual, enfatizando também, questões relativas à saúde psicológica do trabalhador.

Outra Norma igualmente importante é a Occupational Health \& Safety Advisory Services (OSHAS) ${ }^{231}$, em vigor desde 1999, a Norma baseia-se no conceito de que a companhia deve periodicamente analisar e avaliar seu sistema de gestão de segurança e saúde no trabalho. Consiste em um sistema de compatível com a ISO9001 e a

\footnotetext{
${ }^{230} \mathrm{~A}$ minuta da norma ISO26000 pode ser conferida nas informações fornecidas pelo Instituto Nacional de Metrologia, Normalização e Qualidade Industrial do Brasil (Inmetro). Disponível em: <http://www.inmetro.gov.br/qualidade/responsabilidade_social/iso26000.asp >. Referente aos documentos de trabalho da norma ISO26000 como reuniões, projetos e resoluções podem ser vistos no site (em inglês): 〈http://www.iso.org/wgsr>. Acesso em 23.02.2010.

${ }^{231}$ Disponível em: http://www.ohsas.org. Acesso em 16.10.2010.
} 
ISO14001, normas relacionadas a sistemas de gestão da qualidade e do meio ambiente respectivamente, objetivando facilitar a integração entre sistemas de gestão voltados para a qualidade, para o meio ambiente e para segurança e a saúde ocupacional. Permite as empresas gerir riscos operacionais e melhorar a sua performance, com o objetivo de prevenir acidentes, reduzir riscos e colaborar para o bem-estar dos seus colaboradores. Tem como objetivo fornecer os requisitos para um Sistema de Gestão da Segurança e Saúde Ocupacional, permitindo a empresa controlar seus riscos de acidentes e doenças ocupacionais, melhorando seu desempenho. Essa Norma se aplica a qualquer organização que deseje: a) estabelecer um Sistema de Gestão de segurança e saúde no trabalho para eliminar ou minimizar riscos aos funcionários e outras partes interessadas; b) implementar, manter e melhorar continuamente um Sistema de Gestão da Segurança e da Saúde Ocupacional; c) assegurar-se de sua conformidade com sua política; d) demonstrar tal conformidade a terceiros; e) buscar certificação/registro do seu Sistema de Gestão por uma organização externa; e f) realizar uma auto-avaliação e emitir auto declaração de conformidade com esta especificação.

Expomos aqui, algumas iniciativas, normas e certificações que julgamos as mais importantes em se tratando de Direitos Humanos dos trabalhadores e que são baseadas em Documentos internacionais da OIT, OCDE e da ONU. Dessa forma, acreditamos que essas iniciativas são válidas quando utilizadas pelas empresas como ferramenta de gestão para inibir a violência e o assédio no âmbito laboral. Lembramos que, esses indicadores só serão considerados válidos se a empresa realizar um processo de avaliação periódica.

\section{As Ações Preventivas para Inibir o Assédio e as Enfermidades}

\section{Laborais}


Quando falamos em prevenção, estamos nos referindo a antecipação, ou seja, as ações capazes de evitar um dano ou um mal. Depois que o assédio laboral é detectado, então, tratamos das questões relativas à intervenção. Neste item, vamos nos debruçar apenas na prevenção no sentido organizacional e corporativo, pois, não temos a pretensão nem a competência teórica necessária para dissertar sobre o assédio ou as enfermidades laborais relacionadas a tratamento ou cura, nem, tampouco, sobre o aspecto jurídico, como as ações e demandas trabalhistas que poderiam levar a uma possível indenização. Nossa intenção é dissertar sobre as ações preventivas para evitar casos de assédio, mais especificamente, a avaliação institucional.

A importância de se adotar medidas preventivas para inibir os diferentes tipos de assédio no ambiente de trabalho é fundamental, pois, as consequências dessa conduta são extremamente negativas e graves, difíceis de serem resolvidas, porque, o pacto de silêncio por parte de empregadores e dos próprios funcionários acompanha essa forma de violência. Para tanto, urge a necessidade de agir com antecedência, através da adoção de políticas que inibam a conduta de assédio no ambiente de trabalho.

Como já afirmamos alhures, a intervenção dos mecanismos preventivos à proteção da saúde psíquica do trabalhador e aos princípios de ação preventiva, a LPRL da Espanha traz importantes princípios gerais sobre o tema. Todas as medidas que a empresa irá adotar para assegurar a proteção eficaz frente aos riscos laborais avaliados, tendo em conta os princípios da ação preventiva, são, dentre outros: adaptar o trabalho à pessoa, atenuar o trabalho monótono e repetitivo, integrar a prevenção na gestão empresarial e antepor a proteção coletiva e individual (art. 15). A implantação e a aplicação de um plano de prevenção de riscos laborais, deverá, integrar-se em um sistema de gestão da empresa e incluir a estrutura organizativa, as responsabilidades, as 
funções, as práticas, os procedimentos, os processos e os recursos necessários para levar a cabo a ação preventiva (16.1). Com os resultados da avaliação de riscos o empresário deve elaborar um documento escrito: o plano de prevenção e, este plano, se convertirá em obrigatório para todas as empresas (art. 16.2 e 23.1). Os princípios conferem a esta Lei uma perspectiva ergonômica na resolução dos problemas de saúde laboral, cuja a finalidade, é garantir um equilíbrio físico-psíquico-social das pessoas no meio produtivo $^{232}$. A não aplicação ou consideração desses princípios é tida como uma infração por parte do empresário.

A LOIMH da Espanha designa as medidas preventivas para inibir o assédio sexual e o assédio por razão de sexo nas empresas, especificamente no artigo 48 da Lei com o título: Medidas específicas para prevenir el acoso sexual y el acoso por razón de sexo en el trabajo, dispondo o seguinte: “1. Las empresas deberán promover condiciones de trabajo que eviten el acoso sexual y el acoso por razón de sexo y arbitrar procedimientos específicos para su prevención y para dar cauce a las denuncias o reclamaciones que puedan formular quienes hayan sido objeto del mismo. Con esta finalidad se podrán establecer medidas que deberán negociarse con los representantes de los trabajadores, tales como la elaboración y difusión de códigos de buenas prácticas, la realización de campañas informativas o acciones de formación”. Neste item, a Lei traz sabidamente os Códigos de boas práticas, que são ferramentas essenciais para definir ou redefinir medidas preventivas, utilizando-os como suporte com funcionários e as partes interessadas da empresa. "2. Los representantes de los trabajadores deberán contribuir a prevenir el acoso sexual y el acoso por razón de sexo en el trabajo mediante la sensibilización de los trabajadores y trabajadoras frente al mismo y la información a la dirección de la empresa de las conductas o

\footnotetext{
${ }^{232}$ MOLINA NAVARRETE, p. 1150. Apud: OLIVEIRA, Flávia. El Acoso Laboral (...). Op. Cit. Nota $189,($ p.381).
} 
comportamientos de que tuvieran conocimiento y que pudieran propiciarlo". Os representantes dos trabalhadores e os sindicatos exercem papel muito importante nessa etapa, porque, são os mediadores e, sua função, é disseminar em conjunto com a empresa a cultura das medidas preventivas para inibir a violência no âmbito de trabalho. Sobre os representantes e sindicatos e a importância do seu papel nesse processo, trabalharemos a seguir.

De acordo com o Critério Técnico 69/2009 ${ }^{233}$ do Ministério de Trabalho e Imigração da Espanha, as medidas de prevenção que o empresário deve aplicar mediante casos de assédio ou de violência no trabalho que tenham conhecimento ou deveriam ter tido, são aquelas que melhor se adaptem a cada caso ou a cada situação concreta, aplicando as obrigações gerais dos artigos da LPRL citados acima. Outro Documento elaborado pelo Ministério de Trabalho e Imigração é o Guia Explicativa y de Buenas Practicas para La Detección y Valoración de Comportamientos em Materia de Acoso y Violencia en el Trabajo ${ }^{234}$. O Guia enfatiza que as medidas preventivas são aquelas que a empresa adota com antecedência à materialização do dano causado à saúde do trabalhador e, que o objetivo da identificação ou da avaliação como medida preventiva, é conhecer os causadores futuros da violência laboral, para então, adotar medidas necessárias para eliminar, evitar ou reduzir tais riscos.

No Brasil, as medidas preventivas no âmbito legal, são aplicadas pelo SESMT e pela CIPA, que tem por objetivo, observar e relatar as condições de riscos no ambiente de trabalho, solicitando medidas para reduzir e eliminar os riscos existentes

\footnotetext{
${ }^{233}$ CT 69/2009 Sobre las Actuaciones de la Inspección de Trabajo y Seguridad Social en Materia de Acoso y Violencia en el Trabajo. Elaborado pelo Ministerio de Trabajo e Inmigración de España (Inspección de Trabajo y Seguridad Social). O objetivo desse documento é de fixar os critérios de atuação de trabalho em especial da ley de Infracciones y Sanciones en el Orden Social. Disponível em: http://www.mtin.es/itss. Acesso em: 01.03.2010.

${ }^{234}$ Web Site. Op. Cit Nota anterior.
} 
e/ou neutralizá-los, contribuindo para a preservação da saúde e da integridade física dos trabalhadores. No entanto, essas medidas não são suficientes para avaliar, por exemplo, um risco psicossocial, no ambiente de trabalho, que é extremamente subjetivo como o assédio, o burnout ou o estresse ocupacional. Não há, portanto, nenhuma lei ou regulamento específico que trate de ações preventivas ou planos de prevenção do assédio no ambiente laboral no Brasil.

Antes de pontuar algumas ações que a empresa pode realizar para evitar a violência, as enfermidades decorrentes do ambiente de trabalho e o assédio laboral, é importante dizer que, os gestores devem estar dispostos e interessados em que a empresa tenha um clima saudável de trabalho, devendo deixar claro e bem definido o que é a violência no trabalho e no que consiste o assédio, tendo profissionais aptos para redesenhar métodos eficazes de gestão e de prevenção.

Primeiramente, a empresa deverá expor claramente a todos os funcionários semestralmente (ou quando a empresa contratar em seus quadros funcionários novatos) sua política de gestão, seu Código de Conduta e os parâmetros que devem orientar as condições e trabalho. Promover a formação continuada de seus gestores e dirigentes com temas relacionados à administração dos recursos humanos e conflitos laborais é outra ação importante, pois, a pedagogia para evitar o assédio, pode ser eficaz. A partir daí, fazer um cronograma de atividades com todos os funcionários envolvendo reuniões e debates em torno do tema e, nesses encontros permitir aos funcionários que tenham a liberdade de expressar suas opiniões a respeito de assuntos relacionados com o ambiente, as condições de trabalho e o assédio, pode auxiliar na prevenção. 
Nesse sentido, HIRIGOYEN pontua as etapas que a empresa pode utilizar em seu plano de prevenção do assédio moral. A primeira etapa é a sensibilização de todos os empregados sobre a realidade da conduta, por meio de um grande debate, com publicações a respeito dos direitos das pessoas dentro da empresa e a elaboração de folhetos explicativos com detalhes sobre o assédio. A segunda etapa, consta da formação de especialistas internos de medicina social e representantes sindicais. A autora cita, também, como parte do plano de prevenção a importância de um dossiê pedagógico com pesquisas realizadas sobre assédio, incentivando assim, a reflexão e a discussão em torno do tema dentro da empresa ${ }^{235}$.

Nesse sentido, se faz necessário também, a formação continuada dos seus gestores (gerentes, gerentes de grupo ou segmento). A empresa deve ter em sua equipe um especialista em recursos humanos, com uma formação adequada relacionada aos riscos psicossociais no ambiente laboral e, que esteja preparado para responder as dúvidas, ajudar ou encaminhar adequadamente as possíveis denúncias de assédio. É importante salientar que, mesmo uma empresa pequena, poderá traçar um plano para inibir o assédio e outras condutas de violência no ambiente de trabalho.

Reforçamos a idéia de que ambientes de trabalho hostis e pesados desencadeiam enfermidades como o estresse e o burnout e, como consequência, podem favorece a violência e o assédio. Para tanto, a empresa deve atentar para que seus

\footnotetext{
${ }^{235}$ HIRIGOYEN Marie France. Mal Estar no Trabalho...Op. Cit. Nota 98, (pp.322-326), acrescenta nesse item uma importante discussão, dizendo que os casos de assédio devem fazer com que nos questionemos a respeito do funcionamento da sociedade atual e de que nada adianta punir os agressores se não mudarmos nossa mentalidade e começarmos a questionar o porquê desse comportamento. Diz ainda que a prevenção deve começar dentro das escolas, pois segundo ela, as crianças aprendem a partir de modelos, quando as humilhamos ou somos violentos, transmitimos exatamente o que não queremos ensinar: a violência, a humilhação, a ignorância e a hipocrisia. Concordamos com a autora, quando ela aponta que a conduta de assédio deve ser discutido e conhecido já no âmbito escolar. É interessante que mesmo antes de entrar para o mercado de trabalho os futuros trabalhadores possam conhecer, refletir e discutir o assédio moral, sexual e por razão de sexo nas escolas, conhecendo as consequências que essas condutas podem trazer para a vida e para a saúde dos trabalhadores e para a sociedade como um todo.
} 
funcionários e todas as partes interessadas (os stakeholders) usufruam de um ambiente de trabalho agradável, harmonioso e sadio. Mas, para que isso aconteça, a empresa deve conhecer as pessoas e o ambiente em que trabalham, realizando diagnósticos de tempos em tempos para saber o que os funcionários sentem em relação ao ambiente laboral, verificando se eles expõe suas dificuldades em relação a equipe, a metodologia e a organização do trabalho. O uso da avaliação preventiva ou diagnóstica como primeira ferramenta da ação preventiva é aconselhável, porque, é através dos seus resultados, que se poderá encaminhar ações preventivas capazes de inibir as possíveis condutas de assédio, ou então, de identificar essas condutas e encaminhar as respectivas denúncias.

\section{Avaliação Diagnóstica ou Avaliação Interna}

O termo avaliação é muito abrangente. Estamos constantemente avaliando e sendo avaliados. A avaliação é uma atividade que atualmente é realizada por diversos setores da sociedade e em diversas áreas. Trata-se de uma ferramenta adequada ao desenvolvimento de uma linguagem e uma compreensão comuns sobre o trabalho, unindo as pessoas em torno de uma meta única: criar e aperfeiçoar o serviço que lhes compete prestar. A origem da avaliação como atividade profissional, nasceu nos Estados Unidos nos aos 60. Em meados dos 70, se constituíram duas associações profissionais que, em 1984, fundiram-se formando a conhecida e influente American Evaluatión Association (Associacão Norte americana de Avaliação). Os processos de auditoria e avaliação nas empresas, tiveram sua origem na crise econômica de 1929, que conduziu a elaboração das leis de 1933, que criaram a Security Exchange Comisión SEC, a Comissão de Mercado de Valores. LANDIS foi o catedrático de Direito Administrativo que presidiu essa Comissão, desenhando um modelo regulador que obrigava as empresas a se responsabilizarem pela transparência de suas contas, sendo 
sujeitas a uma auditoria privada com uma supervisão final da Administração Pública. A partir daí, se desenvolveu um novo sistema de técnicas, princípios e valores que conformam, atualmente, a qualidade do dinâmico sistema empresarial e financeiro. Isso se deve a implantação dos sistemas de garantia de qualidade: auditoria, avaliação, acreditação e certificação.

A sociedade atual passa por uma grande transformação devido aos processos de globalização. Portanto, os processos avaliativos são elaborados para auxiliar no desenvolvimento das empresas e dos profissionais, onde as sessões coletivas de feedback são a alma do sistema de mediação do desempenho das empresas. Muitas empresas de diversos setores e algumas instituições de ensino no Brasil avaliam seus professores e funcionários e realizam treinamentos utilizando o Ciclo Deming ou Ciclo PDCA. Ele se constitui em um modelo de qualidade total e um forma de gestão a ser seguido para que as metas estabelecidas possam ser atingidas. As etapas do método são: P (Planejar); DO (Fazer); CHECK (Verificar) e ACT (Agir) ${ }^{236}$. Trata-se de um método capaz de realizar um diagnóstico quantitativo e qualitativo. O Ciclo PDCA, objetiva garantir o alcance das metas necessárias para a sobrevivência da Organização. Acrescenta JIMENEZ TELLO ${ }^{237}$, que "la calidad es un factor importante en el mundo de la empresa; si las empresas no ofrecen productos de calidad al mercado y no escuchan su demanda corren peligro de extinción, solo sobreviven aquellas empresas que tienen unos sistemas de organización moderna acorde a lo que la sociedad y el mercado demandan."

\footnotetext{
${ }^{236}$ RAMOS, Cosete. Excelência na Educação - A escola de qualidade total. Rio de Janeiro: Qualitymark, 1992.

${ }^{237}$ JIMÉNEZ TELLO, Pilar. Auditoría Universitaria y Calidad. La evaluación como conquista social ante la competencia universitaria global. UDM, USA, 2009, (p.116).
} 
Destacamos que a futura Norma ISO 26000, deverá enfatizar resultados e melhoria de desempenho e o planejamento será estruturado na metodologia PDCA. Além do Ciclo PDCA, algumas empresas fazem uso de programas de gestão Profissional. O Banco do Brasil por exemplo, possui um programa de Gestão de Desempenho Profissional e Clima Organizacional onde, semestralmente seus funcionários e serviços são avaliados. Para isso, adota dois instrumentos: um instrumento de gestão para acompanhar o desempenho e estimular o crescimento profissional dos seus funcionários e outro instrumento capaz de aferir o clima da Organização ${ }^{238}$. Após os resultados serem tabulados, os funcionários tem acesso a eles e o avaliador pode acompanhar o desempenho individual, fazendo os respectivos registros no sistema.

Nesse sentido, podemos perceber que a qualidade dos serviços está intimamente ligada ao trabalho exercido pelo funcionário, seu aprimoramento e aperfeiçoamento pessoal, assim como o nível do clima organizacional, sendo tema permanente da pauta de reunião dos administradores da empresa com visão estratégica de curto, médio e longo prazos. Mas, na verdade, o que significa dizer que a empresa tem um bom "clima organizacional" ou um bom "clima de trabalho"? Para SÁ e

\footnotetext{
${ }^{238}$ O Banco do Brasil em 2004 iniciou um processo de reformulação de seu instrumento de avaliação denominado GDP - Gestão por Desempenho Profissional, que culminou com o desenvolvimento de um novo modelo intitulado Gestão por Desempenho e Competências. Com isso a empresa objetivou práticas de gestão modernas, como a avaliação 360 graus (avaliação por múltiplas fontes) e o Balanced Scorecard (que reflete o equilíbrio entre os objetivos de curto e longo prazos, permite descrever a estratégia de forma clara, por intermédio de quatro perspectivas: financeira; clientes; processos internos; aprendizado e crescimento. O Balanced Scorecard organiza-se em torno de quatro perspectivas: financeira, cliente, interna e de inovação e aprendizado), e com isso promovendo a melhoria do desempenho profissional e organizacional. Os resultados que a empresa espera com a GDP é contribuir para a melhoria dos resultados organizacionais, possibilitar a melhoria permanente do atendimento ao cliente, contribuir para o desenvolvimento profissional do funcionário, estimular o desempenho excelente, permitir o acompanhamento da evolução do desempenho individual e coletivo, possibilitar a auto-análise e estimular o auto desenvolvimento, entre outros. Fonte: Banco do Brasil (GDP): você de olho no seu placar cartilha auto-instrucional. Brasília, Banco do Brasil, 1998.
} 
GUIMARÃES 239 , clima organizacional é "o somatório das percepções que os empregados têm de todo um contexto organizacional que influencia diretamente a convivência de cada indivíduo no ambiente de trabalho, trazendo consequências para os desempenhos individuais e, portanto para o desempenho da organização”.

Notamos que há uma diversidade de fatores envolvidos no conceito de clima organizacional. Alguns autores analisam o clima específico para o desenvolvimento ou surgimento de algo, como por exemplo a criatividade, a liderança ou a motivação. Aqui nesse trabalho, para nós, o clima organizacional deve ser visto como um conjunto de atributos que envolvem, um clima favorável e harmonioso, onde as pessoas exercem um bom relacionamento interpessoal e que sabem interagir de maneira clara e sincera. É certo afirmar que, empresas que possuem clima organizacional instável, com conflitos, problemas de relacionamento e falta de comunicação, tem grandes chances de desencadear processos de violência, assédio e enfermidades laborais como o estresse e burnout.

Outra empresa brasileira que desenvolve um programa avaliativo é a Natura. Ela trabalha na área de pesquisa, criação, desenvolvimento, distribuição e comercialização de cosméticos. Em seu processo de gerenciamento de desempenho, realiza uma abordagem dinâmica e contínua voltada ao planejamento do colaborador e do seu crescimento pessoal e profissional. Baseia-se em mapear os recursos humanos da empresa para identificar performances diferenciadas e estimular uma cultura de desempenho. Em 2001, foram realizados os processos de avaliação interna e externa. A avaliação interna utilizou sete critérios de excelência do prêmio nacional de qualidade 2001, da Fundação Prêmio Nacional de Qualidade. Eles envolveram liderança,

\footnotetext{
${ }^{239}$ SÁ LEITÃO, Jacqueline Silveira e GUIMARÃES, Tomás de Aquino. Metodologia de Diagnóstico de Clima Organizacional em Ambiente de Inovação Tecnológica. Apud: $22^{\circ}$ Encontro Nacional de Pós Graduação em Administração - ENANPAD, 1998.
} 
estratégias e planos, clientes e sociedade, informação e conhecimento, pessoas, processos e resultados. A avaliação externa contemplou a discussão e análise das macro tendências em diversas áreas estratégicas da Companhia. Segundo a empresa, nesse exercício, foi destacada a agilidade em atuar com novos parâmetros para cumprir diretrizes com notável comprometimento dos seus vários setores. A empresa enfatiza a evolução contínua de seus colaboradores internos e externos com sólidos investimentos em treinamentos profissionais, utilizando ferramentas específicas a cada realidade. A avaliação realizada na Natura é um exemplo de que, cada vez mais, as empresas estão preocupadas em analisar e definir melhores desempenhos organizacionais, adequando seus objetivos estratégicos a uma avaliação diagnóstica.

A subsidiária brasileira da Siemens é outra empresa que verifica a qualidade dos seus serviços junto aos funcionários. Ela é considerada uma potência mundial em engenharia eletro eletrônica e tem um programa de treinamento em gestão para auxiliar o processo avaliativo mais transparente e mais eficaz. Katalifós, funcionário da Siemens, diz que, um sistema seja eficaz de desempenho só existe se, paralelo a ele houver uma avaliação constante com feedbacks ${ }^{240}$ entre os chefes e os funcionários da empresa. O Indicador de Desenvolvimento Humano Organizacional (IDHO) foi criado pela Revista Gestão RH em 2007. A organização do prêmio analisa as mil maiores empresas brasileiras considerando itens como: o capital humano, a governança corporativa, a sustentabilidade e a transparência. A Siemens foi uma das

\footnotetext{
${ }^{240}$ Nesse sentido a dimensão do feedback refere-se ao grau que um indivíduo recebe informações diretas a respeito do seu trabalho e desempenho. Ele pode vir da execução da tarefa (intrínseco) ou dos colegas e do superior hierárquico da empresa (extrínsecos). Dessa maneira o funcionário pode perceber se o seu desempenho e os resultados de seu trabalho dentro da empresa estão sendo alcançados.
} 
escolhidas com uma das "10 Mais" pelas melhores práticas de gestão de RH. A empresa também foi destaque na dimensão: Capital Humano ${ }^{241}$, diz o funcionário.

Esses são alguns exemplos de empresas que submetem seus funcionários a diagnósticos avaliativos, enfatizando o clima organizacional de trabalho e, principalmente, o desenvolvimento profissional, ligados à missão, aos valores e ao Código de Conduta da empresa. Eles demonstram que as avaliações de desempenho dos serviços prestados e do desenvolvimento dos funcionários já fazem parte da vida de muitas empresas que atuam no Brasil. Portanto, no entender de JIMENEZ TELLO ${ }^{242}$, a avaliação é uma forma legítima para que os organismos ou instituições, tanto públicos como privados, se proponham a adotar os mecanismos de auto-regulação. Ademais, a implantação de um sistema de avaliação, obriga as instituições ou empresas a estabelecerem sistemas de garantia de qualidade internos e prepararem-se para as avaliações externas. Lembramos que outros setores da economia como os restaurantes, hotéis e lojas de departamento, também adotam avaliações constantes, proporcionando aos clientes, a oportunidade de sugerir mudanças e apontar soluções para a melhoria dos serviços prestados por elas.

Neste contexto, a avaliação institucional não é considerada somente um instrumento técnico, mas, deve levar em conta também, as dimensões ética, política e social da empresa, sendo imprescindível que todos avaliem e acompanhem os resultados

\footnotetext{
${ }^{241}$ A proposta do "IDHO" leva em conta a qualidade de vida das pessoas nas empresas e a qualidade da gestão e seu resultado prático e econômico. Para isso, envolve a organização em todos os pilares, a saber: gerar valor e lucro para seus colaboradores, acionistas e para toda a sociedade global. A escolha das empresas pela Revista foi em função dos resultados da pesquisa realizada, foram classificadas de acordo com o seu desempenho em desenvolvimento humano organizacional obedecendo o critério das quatro dimensões: cidadania empresarial; capital humano (clima organizacional e qualidade de vida); governança corporativa; e transparência (balanço social e relatório de sustentabilidade). Web Site da Revista: < http://www.gestaoerh.com.br/>. Acesso em 06.03.2010.

${ }^{242}$ JIMÉNEZ TELLO, Pilar. Multiculturalidad y Sociedad del Conocimiento. Perspectiva de género. Auditoria y evaluación como instrumento decisivo para el desarrollo sustentable de los derechos de la mujer en la sociedad del conocimiento. Ed. Comares, 2009, (p.16).
} 
do processo. Para valorar o grau de interiorização e de comparação, para seguir avançando, JIMÉNEZ TELLO ${ }^{243}$, afirma que,

En una definición más cercana al ámbito del Derecho Administrativo diremos que la evaluación es un sistema para implantar la justicia, reconocer los méritos y la capacidad que es un principio constitucional e, incluso, implantar el principio de igualdad que es el tratamiento desigual a los desiguales.

Portanto, não basta avaliar apenas o grau de alcance dos objetivos estabelecidos, mas também, dos próprios objetivos e das consequências não previstas. Nesse sentido, pode-se dizer que a avaliação é o processo capaz de obter e fornecer dados relevantes para o julgamento de decisões avaliativas. Para se formular um juízo de valor, é cabível analisar as condições do ato de avaliar, considerando para quem e para que avaliar. BARBIER, utiliza-se da necessidade do juízo de valor, afirmando que: "um ato de avaliação que chegue ao final é um ato que conduz a produção de um juízo de valor. A presença deste é que permite dizer se há ou não avaliação. O juízo de valor constitui o sinal da avaliação ${ }^{244}$.”

Assim sendo, o ato de avaliar torna-se julgar ou apreciar alguém ou alguma coisa, com base num determinado juízo de valores. Para isso, é necessário ter acesso a dados qualitativos e quantitativos perante critérios claros e definidos. A avaliação deve ser sistemática e contínua. O enfoque sistemático que é dado à avaliação, significa que ela deve ser um processo ordenado através do qual, se identificam as necessidades, selecionam-se os problemas, determinam-se alternativas e oportunizam-se constantes revisões. Como consequência disso, ela deve ser contínua, para que não se

\footnotetext{
${ }^{243}$ JIMÉNEZ TELLO, Pilar. Op.Cit. Nota anterior.

${ }^{244}$ BARBIER, Jean- Marie. Avaliação em Formação. Porto, Afrontamento, 1990, (p.77).
} 
percam nenhuma das metas traçadas durante o processo, que é uma construção permanente.

LUCKESI, destaca que "o ato de avaliar implica dois processos articulados e indissociáveis: diagnosticar e decidir. Não é possível uma decisão sem um diagnóstico, e um diagnóstico sem uma decisão é um processo abortado ${ }^{245}$.” Então, o diagnóstico inicia-se a partir da coleta de informações, do processamento dos dados coletados, que inclui a classificação, a interpretação e a confirmação deles. Ao coletar os dados, o avaliador deverá identificá-los e reuni-los em categorias específicas. As categorias irão favorecer a classificação para posterior interpretação, possibilitando ao avaliador conhecer o objeto avaliado.

O segundo passo é a interpretação dos dados avaliados, comparando-os com base em normas e em teorias utilizadas. LUCKESI ainda considera o passo da interpretação como a qualificação do objeto, estabelecida com base em critérios ou padrões determinados, podendo ser qualificada em positiva ou negativa. A tomada de decisão frente à avaliação descrita como satisfatória ou insatisfatória, cabe reflexões que implicam alterações no projeto da empresa utilizado, antecipando, identificando e interpretando as possíveis falhas do processo.

\section{A Avaliação 360 Graus ou Avaliação de Múltiplas Fontes}

A Avaliação 360 graus é um diagnóstico realizado pela empresa que tem como resultados feedbacks de múltiplas fontes, também conhecida como Avaliação de Múltiplas Fontes. O método é comumente utilizado na área de Gestão de Pessoas e apóia o desenvolvimento do desempenho profissional, contribuindo para o

\footnotetext{
${ }^{245}$ LUCKESI, Cipriano. Avaliação da Aprendizagem Escolar. São Paulo: Cortez Editora, 2005, (p.8).
} 
desenvolvimento de competências e talentos dentro da empresa. No processo, todos os participantes recebem simultaneamente feedbacks estruturados de seus superiores hierárquicos colegas, subordinados e outros stakeholders. O participante realiza também uma auto-avaliação. Esses feedbacks são feitos através de questionários com perguntas fechadas ou abertas, divididas em blocos e contendo clima organizacional, desempenho nas atividades, alcance de metas e perspectivas de negócios e vendas de produtos e serviços (no caso de empresas financeiras), relação interpessoal, trabalho em equipe e outras questões ligadas à missão e aos princípios de cada empresa. Os resultados das respostas são confidenciais e a pessoa que as recebe não sabe quem a avaliou. Somente o avaliado terá acesso ao resultado integral da avaliação.

Entretanto, acreditamos que a avaliação 360 graus só será realmente válida e eficaz se a empresa realizar a avaliação qualitativa após receber os resultados desses feedbacks. Se forem evidenciados conflitos ou dificuldades no clima de trabalho ou na relação interpessoal da equipe nos feedbacks recebidos, é importante que a empresa realize uma avaliação qualitativa, devendo haver uma continuação para que os especialistas na área de gestão de pessoas ou dos recursos humanos ou, até mesmo, os próprios funcionários da equipe e superiores, possam sugerir de maneira conjunta melhorias e planificarem um plano estratégico como ações preventivas para evitar maiores danos, como condutas de assédio ou enfermidades laborais. Entretanto, é importante salientar que, nesse processo, permeia a subjetividade, já que é uma ferramenta que envolve julgamentos pessoais e não apenas fatos. Por isso, o cuidado em interpretar os dados e difundi-los é essencial para que a ferramenta não se transforme em castigo, obrigação ou medo. A tabulação dos dados é geralmente realizada por meios informáticos, mas, a avaliação qualitativa que deve ser realizada, como já 
dissemos, deve ser feita por um grupo de profissionais treinados. Nesse sentido, o impacto desse tipo de ferramenta, CHURCH e BRACKEN ${ }^{246}$ ressaltam:

Quando gerentes comparam os resultados das avaliações feitas por seus colegas com suas próprias percepções, eles são envolvidos num processo de reflexão que resulta em um maior nível de consciência de seus atos e das consequências que essas ações têm sobre os outros, em vários níveis, dentro e fora da organização.

O autor acrescenta uma importante informação, na medida em que a avaliação por múltiplas fontes age sobre todos os níveis e setores da empresa, proporcionando assim, um sentimento maior de responsabilidade por parte dos gerentes e/ou superiores hierárquicos a respeito de seus métodos de trabalho e de gestão. Por outro lado, o fato de que, as empresas tem sido continuamente bombardeadas por sedutoras ferramentas e instrumentos inovadores de recursos humanos, - incluindo os programas de desenvolvimento de lideranças baseados em feedbacks de múltiplas fontes - faz com que, muitas vezes, elas incorporem as avaliações sem uma percepção mais criteriosa e mais ampla sobre como esses instrumentos irão efetivamente atender as necessidades. Ficam sem questionar o sentido do uso desses instrumentos na relação empresa-pessoa, em relação aos dados objetivos e as características e contexto da $\operatorname{organização~}^{247}$.

Nesse sentido, acreditamos que as avaliações internas, de 360 graus ou de múltiplas fontes, são válidas no sentido técnico, porque, visualizam o desenvolvimento profissional dos seus funcionários, a liderança e a competitividade. $\mathrm{O}$ “clima organizacional" faz parte de um dos itens dessas avaliações, o que esperamos é que nesse item, a ferramenta aborde questões ligadas ao assédio moral, assédio sexual e o

\footnotetext{
${ }^{246}$ CHURCH E BRACKEN, 1997, (p.150). Apud: REIS, Germano Glufke. Avaliação 360 Graus. Um Instrumento de Desenvolvimento Gerencial. $2^{\mathrm{a}}$ edição, São Paulo: Atlas, 2007, (p.53).

${ }^{247}$ REIS Germano Glufke. Avaliação 360 Graus (...). Op. Cit. Nota anterior, (p.69).
} 
assédio por razão de sexo no ambiente de trabalho. A implantação desta ferramenta na empresa pode contribuir significativamente na detecção desses problemas. Lembrando que a empresa ao utilizar a ferramenta, deve garantir o sigilo e o anonimato das manifestações, para que o trabalhador se sinta seguro para identificar claramente os conflitos e problemas que poderão existir.

\section{Avaliação em Direitos Humanos}

Depois de analisarmos a avaliação interna, a avaliação 360 graus ou avaliação de múltiplas fontes, vamos discorrer a respeito dessa ferramenta na perspectiva dos Direitos Humanos. Nos capítulos anteriores, vimos as Normas internacionais de Direitos Humanos para as empresas e, dentro delas, o Pacto Global, que determina sua avaliação periódica através da $\mathrm{COP}^{248}$. Para que as empresas possam ser consideradas "notáveis", devem enviar um relatório de suas estratégias em relação às normas do Pacto, incluindo as iniciativas a respeito dos Direitos Humanos. Esse tipo de ferramenta é um diagnóstico que a empresa faz de si mesma e se questiona se as Normas e medidas implementadas até a data da publicação do Documento estão sendo realizadas. É importante nessa tarefa, que as empresas tornem público esse diagnóstico, para que a sociedade tome conhecimento do compromisso que a Organização tem com os princípios do Pacto, com os trabalhadores, consumidores e com a comunidade onde está inserida.

Dentro desse contexto, destacamos o Exame Periódico Universal (EPU) da Nações Unidas, criado através da Assembléia Geral da ONU em 15 de Março de 2006 pela Resolução 60/251, que instituiu o Conselho de Direitos Humanos. O EPU é um mecanismo onde todos os Estados membros são examinados a cada quatro anos

\footnotetext{
${ }^{248}$ Para ver a lista de empresas notáveis em: < http://www.unglobalcompact.org/COP/notable_cops.html>.
} 
através de processos de auditoria e avaliação para analisar as obrigações e compromissos em matéria de Direitos Humanos. De acordo com o atual Secretário Geral da ONU, Ban Ki-moon, o EPU tem um grande potencial para promover e proteger os Direitos Humanos nos mais escuros cantos do mundo. É um processo único e prevê a possibilidade de cada Estado declarar as ações tomadas para melhorar a situação dos Direitos Humanos. O Exame é projetado para assegurar um tratamento igual para todos os países avaliados no que respeita os Direitos Humanos ${ }^{249}$. O Brasil foi avaliado no ano de 2008 e recebeu algumas considerações de outros países a respeito da redução da pobreza e desigualdade social, do sistema penal judiciário, dos povos indígenas e da reforma agrária. Sugeriram ainda, um cuidado maior do país a respeito da violência doméstica contra as mulheres, do trabalho infantil e do trabalho escravo, que ainda são temas que merecem mais atenção do poder público. Já a Espanha teve seu último informe em março do decorrente ano e destacou-se, entre outras sugestões, a proteção dos Direitos Humanos do trabalhador migrante e das minorias ${ }^{250}$.

Essas recomendações ou sugestões servem para propor ao país avaliado ações ou medidas de várias naturezas com o intuito de melhorar a sua situação em Direitos Humanos. O Exame já começa a render os seus frutos, visto que muitos países assumiram compromissos a fim de melhorar suas políticas públicas a respeito dos Direitos Humanos e dispostos a ratificar tratados internacionais de Direitos Humanos dos quais ainda não eram signatários. Portanto, é uma ferramenta de grande relevância que orienta o Estado e a sociedade civil organizada a respeitar e garantir os Direitos Humanos.

\footnotetext{
${ }^{249}$ Página da ONU (Oficina do Alto Comissionado para os Direitos Humanos. Disponível em: http://www.ohchr.org >. Acesso em 17.10.2010.

${ }^{250}$ Ambos Informes em Inglês:<http://www.ohchr.org/EN/HRBodies/UPR/Pages/UPRMain.aspx>. Acesso em 16.06.2010.
} 
De acordo com as normas de Direitos Humanos para as empresas da ONU em seu Documento "Las Normas de Derechos Humanos de la ONU para Empresas: Hacia la responsabilidad legal 251 ", estipulam-se os mecanismos de verificação que as empresas devem adotar para saber se as Normas estão sendo cumpridas, e seu compromisso firmado está sendo objeto de gestão. As empresas devem realizar periodicamente uma auto-avaliação, fazer público o informe sobre o cumprimento das normas e aplicar planos e medidas de reparação.

Dentro disso, a empresa deve utilizar-se da avaliação como meio para rever e aperfeiçoar seu projeto de gestão administrativa. Segundo o professor BRUNET, “(...) sem avaliação não há planejamento, e sem planejamento, não há norte.” E, todo o planejamento, deve ser objeto de constantes revisões críticas para que se promova a contínua melhoria da qualidade dos serviços prestados no âmbito da gestão empresarial.

Vale salientar também, outro Documento importante a respeito de avaliação em Direitos Humanos para as empresas que é o Guía de Evaluación y Gestión del Impacto sobre los Derechos Humanos ${ }^{252}$. Esse guia é elaborado pela International Business Leaders Forum ${ }^{253}$, The Global Compact $^{254}$ e International Finance Corporation $^{255}$. O Guia tem o objetivo de permitir que as companhias de diferentes

\footnotetext{
${ }^{251}$ Op. Cit. Nota 204.

${ }^{252}$ Disponível em: <http://www.pactoglobal.org.ar/content.asp?id=5>. Acesso em: 05.03.2009.
}

${ }^{253}$ A International Business Leaders Forum trabalha com empresas, governos e sociedade civil para reforçar a contribuição que as empresas podem dar para o desenvolvimento sustentável. É uma organização independente, sem fins lucrativos, portada atualmente por mais de 100 das principais empresas do mundo. A IBLF fornece conselhos estratégicos para as empresas que lhes permitam compreender e responder aos desafios do desenvolvimento que enfrentam, sobretudo quando operam em transição e economias emergentes. Desde 1990, a organização trabalha em mais de 90 países, beneficiando a longo prazo as relações com as redes regionais em todo o mundo, muitos dos quais IBLF tem ajudado a criar ou reforçar. As atuais áreas de trabalho incluem elevar padrões empresariais sustentáveis, melhorando as perspectivas de empresas e emprego, e permitindo que as empresas a contribuam para a saúde e desenvolvimento humano. Disponível em: http://www.iblf.org/. Acesso em 05.03.2009.

${ }^{254}$ Ver mais no capítulo III desse trabalho: O Pacto Global das Nações Unidas para as Empresas.

${ }^{255}$ A International Finance Corporation, com sede em Washington (USA), é o ramo do setor privado do Grupo do Banco Mundial e sua missão é promover o investimento sustentável do setor privado dos 
setores empresariais façam um ensaio com a prática em avaliação de gestão em Direitos Humanos, sendo que, sua nova versão está sendo realizada e será publicada ainda este ano. O guia traz perguntas frequentes a respeito de como realizar uma avaliação proporcionando às empresas a oportunidade de fortalecerem seus procedimentos de gestão: que sejam proativas, em lugar de reativas em matéria de Direitos Humanos. Segundo o Documento, o processo de avaliação de impacto sobre Direitos Humanos possibilita que uma empresa proceda sistematicamente a detectar, proceder e responder a possíveis efeitos de um projeto empresarial sobre Direitos Humanos, tomando em conta o seguinte: as pessoas: aquelas cujos direitos podem resultar afetados, assim como as partes interessadas; o país ou a localidade; a política e as práticas da empresa no setor em que opera; as relações empresariais dentro do projeto; o contexto temporal do projeto e seu ciclo de vida. Os índices da ferramenta são: as práticas laborais (trabalho forçoso, trabalho infantil e trabalhadores jovens, não discriminação, liberdade de associação, saúde e segurança no lugar de trabalho, condições de emprego e trabalho); Impacto com a comunidade (segurança, administração da terra, saúde e segurança do meio ambiente, corrupção e suborno, produtos da empresa) e gestão da cadeia de abastecimento.

O Instituto Dinamarquês de Diretos Humanos - The Danish Institute for Human Rights \& Business, projetou uma ferramenta denominada "Avaliação do cumprimento dos Direitos Humanos (HRCA)". Ela foi elaborada para auxiliar as empresas a detectar possíveis violações de Direitos Humanos causadas pelo impacto de suas atividades, seus empregados, a comunidade local e as demais partes implicadas. A ferramenta conta com mais de 300 perguntas relacionadas com os indicadores e versões

países em desenvolvimento, ajudando a reduzir a pobreza e melhorar a vida das pessoas, concedendo empréstimos e consultorias para o setor privado nos países em desenvolvimento. Disponível em: $<$ http://www.ifc.org/Portuguese>. Acesso em 05.03.2009. 
especializadas, para que as empresas possam utilizar a avaliação de listas de verificação.

O site também contém um grande número de outras ferramentas, incluindo programas para ajudar as empresas a gerir os Direitos Humanos na cadeia de abastecimento ${ }^{256}$. É importante salientar que, a versão em espanhol da ferramenta "Quick Check" é o resultado de uma parceria entre o Programa Human Rights \& Business, ESADE e o Programa de Empresa e Direitos Humanos da Escuela de Cultura de Paz 257 (Universidade Autónoma de Barcelona - Espanha).

Acreditamos que as empresas podem dispor de uma Avaliação em Direitos Humanos pelo menos uma vez a cada semestre, dependendo do tamanho da empresa e do número de funcionários. É importante lembrar que o setor de recursos humanos ou o de Gestão de Pessoas da empresa deve contar com as ferramentas adequadas para a tabulação dos dados e dos resultados. A ferramenta HRCA é um modelo ideal porque possui indicadores claros e precisos a respeito dos direitos fundamentais do trabalhador. No que refere ao assédio e a violência no ambiente de trabalho, a empresa pode utilizar da seguinte questão: A empresa toma medidas preventivas para proteger seus trabalhadores contra atos de assédio moral, assédio sexual ou assédio por razão de sexo, violência, abuso ou ameaças no ambiente de

\footnotetext{
${ }^{256}$ As perguntas e indicadores desta ferramenta (HRCA); foram desenvolvidas com base em Tratados e Convenções de Direitos Humanos, incluindo a Declaração Universal de Direitos Humanos, as Convenções da OIT e os Pactos Internacionais de 1966. A ferramenta possui 350 perguntas e 1000 indicadores de direitos humanos na base de dados, oferecendo um programa informático interativo, permitindo que as empresas usuárias possam selecionar e modificar as informações da base de dados de acordo com o tipo de negócio e área de atividade. É importante destacar que as normas e os indicadores da ferramenta são atualizados todos os anos de acordo com os comentários das empresas que a utilizam e das organizações de Direitos Humanos.Ver mais no site: <http://www.humanrightsbusiness.org>. Acesso em 05.03.2009.

${ }^{257}$ A Escola de Cultura de Paz, criada em 1999, com o objetivo de trabalhar os Direitos Humanos, promover a compreensão e a prática da cultura de paz, analisando os conflitos, e a sua prevenção. Vale salientar o importante e prático guia de Direitos Humanos para as empresas, citado anteriormente neste trabalho, traz os Direitos Humanos para as empresas os aspectos de como e o que avaliar. Disponível em: http://www.pangea.org/unescopau/img/programas/derecho/guia/guia.swf. Acesso em 05.03.2009.
} 
trabalho? Para responder a pergunta, a empresa deve analisar e responder os seguintes indicadores $^{258}$ :

1) A empresa utiliza uma política de informação sobre o assédio moral, o assédio sexual e o assédio por razão de sexo no ambiente de trabalho e informa seus funcionários sobre as ações disciplinarias existentes caso ocorra uma dessas condutas ?

2) A empresa utiliza medidas preventivas para inibir o assédio e a violência no ambiente de trabalho?

3) A empresa tem um mecanismo para receber denúncias de assédio e violência no ambiente de trabalho e conta com profissionais competentes para tratar o tema?

4) A empresa investiga de imediato todas as queixas de violência e assedio, tomando as ações disciplinarias adequadas?

5) Os gestores ou superiores hierárquicos recebem informação adequada sobre como utilizar técnicas de gestão, incluindo as medidas disciplinarias, que incluem a proibição de condutas assediadoras, violentas e abusivas ?

5) A empresa facilita a interação dos funcionários e das equipes para que a comunicação seja sincera e aberta facilitando a resolução de conflitos?

\footnotetext{
${ }^{258}$ Os indicadores são orientações que ajudam a determinar se a empresa cumpre ou não a questão principal. Os indicadores devem ser contextualizados pela empresa dependendo do tamanho, do ramo de atividade e do país onde está inserida e deve estar em conformidade com sua política de gestão, com seus códigos de ética e conduta. A empresa escolherá o método de quantificação mais adaptável a sua realidade, o importante é que a avaliação contemple questões relativas a violência, ao assédio no ambiente de trabalho e as ações preventivas para inibir essas condutas. É fundamental que seja realizada a avaliação qualitativa, ou seja, a análise e a discussão dos resultados. A empresa poderá realizar essa avaliação com os gestores ou superiores hierárquicos e com os funcionários, desde que os indicadores sejam adaptados a cada realidade.
} 
6) A empresa toma medidas de prevenção para proteger os funcionários contra condutas assediadoras e violentas de pessoas externas como usuários, clientes e fornecedores?

7) A empresa trata de imediato o estresse e as tensões no ambiente de trabalho que podem posteriormente se transformar em condutas de assédio e de violência? ${ }^{259}$

A questão está baseada nos princípios gerais da Declaração Universal dos Direitos Humanos (1948), Artigo 5º do Pacto Internacional de Direitos Civis e Políticos (1966), Artículo $7^{\circ}$. E os indicadores estão de acordo com as Diretrizes para as Empresas Multinacionais da OCDE, com a Declaração Tripartite de Princípios sobre Empresas Multinacionais e a Política Social da OIT. E ainda com os princípios do Pacto Global e das Normas de Direitos Humanos para as Empresas da ONU.

A avaliação em Direitos Humanos nas empresas, ainda tem um longo caminho a percorrer. Porém, ela não é desconhecida ou desprezada pelas empresas que seguem as normas internacionais de Direitos Humanos. Pelo contrário, é um projeto que tem possibilidades de alcançar seus objetivos traçados desde o início. Ao final desse item, podemos afirmar que a avaliação é um instrumento central da implantação real da proteção dos Direitos Humanos no âmbito da empresa.

\section{O Método de Avaliação de Riscos Psicossociais}

O questionário Psicossocial de Copenhague (CoPsoQ) foi desenvolvido em 2000 por uma equipe de investigadores do Instituto Nacional de Saúde Ocupacional

\footnotetext{
${ }^{259}$ Fonte adaptada da Avaliação de cumprimento dos Direitos Humanos HRCA (Quick Check). Op. Cit. Nota 256.
} 
da Dinamarca. Utiliza-se dos modelos Demanda - Apoio e controle social, esforço recompensa e dupla presença. A adaptação para a Espanha foi realizada pelo ISTAS. $E l$ Método de Evaluación de Riscos Psicossociales (CoPsoQ) ${ }^{260}$, é um instrumento de avaliação orientado para a prevenção. Um questionário com características bem definidas, individual e anônimo, possui três versões dependendo do número de trabalhadores e do tamanho da empresa e pode ser aplicado em qualquer tipo de trabalho ou ramo de ocupação, inclui somente, aquelas dimensões nas quais existem evidências científicas que afetam a saúde do trabalhador, orientado para a participação e ação.

O Manual de La Evaluación de Riesgos Psicosociales en el Trabajo do ISTAS $^{261}$, justifica o método afirmando que a relação entre a organização do trabalho e a saúde é evidente, os efeitos da organização do trabalho são intangíveis e inespecíficos e se manifestam através de processos psicológicos como o estresse, incluindo diversos aspectos que podem afetar a saúde tanto física, como mental e social do trabalhador. $\mathrm{O}$ Documento acrescenta ainda, que o baixo controle sobre o conteúdo das tarefas, as altas exigências psicológicas e o baixo apoio dos colegas e chefes de trabalho podem ser os fatores de estresse no âmbito laboral. As questões propostas no questionário se

\footnotetext{
${ }^{260}$ Segundo o ISTAS: "El método CoPsoQ es un instrumento de evaluación de riesgos psicosociales y propuesta de acción preventiva. Las particularidades de este método son que evalúa todas aquellas características de la organización del trabajo que se han identificado como riesgos psicosociales y para las que se tienen suficientes evidencias cientificas de que pueden representar un riesgo para la salud y el bienestar de los trabajadores/as. Se puede usar para cualquier tipo de trabajo y en cualquier sector de actividad económica, lo que garantiza que se puede utilizar para evaluar todos los puestos de trabajo de una misma empresa, lo que obliga a pasar a todo el mundo por el mismo rasero y permite así evitar discriminaciones. Caracteriza muy bien el problema de exposición y lo localiza perfectamente, lo que permite diseñar soluciones preventivas adecuadas. La participación se considera esencial en todo el proceso de intervención preventiva. La licencia de uso del método exige la participación de las tres partes, empresario y sus representantes, trabajadores y sus representantes y técnicos. Es una metodología de utilización pública y gratuita". Disponível em: 〈http://www.istas.ccoo.es>. Acesso em: 07.03.2010.

${ }^{261}$ Método ISTAS 21 CoPsoQ. Manual Para la Evaluación de Riesgos Psicosociales en el Trabajo. <http://www.istas.ccoo.es>. Acesso em: 07.03.2010.
} 
apresentam divididas em dimensões, a saber: excesso de exigências psicológicas (quando o trabalhador tem que realizar suas tarefas de forma rápida e de maneira irregular, devendo tomar decisões difíceis, sem expressar suas opiniões); falta de influência e desenvolvimento (quando o trabalhador não tem autonomia para realizar suas tarefas, quando não se pode adaptar os horários com a vida familiar); falta de apoio e qualidade na liderança (quando se trabalha de forma isolada sem apoio de colegas ou chefes, escassas compensações (falta de respeito no âmbito laboral, insegurança contratual, mudanças de setor ou postos sem o consentimento do trabalhador, tratamento injusto e remuneração baixa); dupla presença (quando o/a funcionário deve administrar o trabalho doméstico com o trabalho remunerado, conciliando a vida laboral e familiar).

As perguntas relacionadas ao questionário apresentam questões que envolvem o desgaste emocional, as emoções reprimidas, a dificuldade em expressar opiniões, como é lidar com a influência dos outros, as opiniões e as ordens dos colegas e chefes, o entusiasmo com o trabalho e o compromisso com a empresa. Sobre os conflitos, o relacionamento interpessoal, a saúde mental e como o trabalhador se sente física e emocionalmente. Essas questões distribuídas em forma de perguntas podem detectar problemas de saúde e suas respostas, servem como base para que se tomem medidas de ações preventivas.

A importância de questões desse tipo é enfatizado no Reglamento de los Servicios de Prevención (RPS): “La evaluación de los riesgos laborales es el proceso dirigido a estimar la magnitud de aquellos riesgos que no hayan podido evitarse, obteniendo la información necesaria para que el empresario esté en condiciones de tomar una decisión apropiada sobre la necesidad de adoptar medidas preventivas y, en 
tal caso, sobre el tipo de medidas que deben adoptarse ${ }^{262}$." Lembramos que questões como essas também podem detectar se o trabalhador está sofrendo ou pode sofrer algum risco de assédio ou alguma outra forma de violência psicológica no trabalho.

O guía CoPsoQ ainda sugere que a empresa organize algumas medidas concretas que: a) reduzcan las exigencias psicológicas del trabajo; b) incrementen las oportunidades de desarrollo de habilidades y conocimientos, evitando el trabajo monótono y repetitivo; c) incrementen el nivel de control sobre los tiempos de trabajo a disposición (pausas, descansos, permisos, vacaciones; d) potencien la participación en las decisiones relacionadas con el contenido de las tareas; e) potencien la decisión de los/as trabajadores/as sobre sus condiciones de trabajo; f) faciliten el apoyo entre el personal de la empresa; g) fomenten la claridad y la transparencia organizativa, definiendo puestos de trabajo, tareas asignadas y margen de autonomía; $h$ ) proporcionen formación y habilidades directivas no autoritarias; i) eliminen la competitividad entre compañeros y/o departamentos; $j$ ) eliminen el trabajo aislado; l) garanticen el respeto y el trato justo; $m$ ) garanticen la seguridad y la estabilidad en el empleo y en las condiciones de trabajo (jornada, sueldo, etc.; $n$ ) eliminen la discriminación por sexo, edad, etnia o de cualquier otra índole; o) faciliten la compatibilización entre la vida laboral y familiar ${ }^{263}$ ",

Como já exposto lembramos que na Espanha existem medidas legais referentes às ações preventivas de riscos psicossociais no ambiente de trabalho, como é o caso da LPRL, o Real Decreto RSP e a LOIMH. O Brasil conta com a CLT, que traz a

\footnotetext{
${ }^{262}$ Artigo 3 do Real Decreto 39/1997 de 17 de enero por el que se aprueba el Reglamento de los Servicios de Prevención (RSP). Disponível em: < http://www.boe.es/boe/dias/1997/01/31/pdfs/A0303103045.pdf>. Acesso em 09.03.2010.

${ }^{263}$ Op. Cit. Nota anterior, (p.18).
} 
CIPA e a SESMT $^{264}$ que apresentam a prevenção dos riscos físicos, não fazendo menção às ações para prevenir riscos psicossociais no ambiente de trabalho.

Além das avaliações e diagnósticos que são ações de medidas preventivas, acreditamos que existem outros recursos que as Organizações podem utilizar para tornar o ambiente de trabalho mais harmonioso, sadio e livre de riscos que possam afetar a saúde do trabalhador, evitando o assédio e a violência.

A primeira medida que a empresa poderá adotar é a comunicação e difusão sobre o tema, começando pela formação e informação dos chefes e dos superiores hierárquicos a respeito das enfermidades laborais que podem surgir no ambiente de trabalho, como o estresse e o burnout e as condutas de assédio moral, assédio sexual e assédio por razão de sexo. Essa formação poderá ser realizada através de pequenos seminários ou reuniões com a presença de um profissional para que os chefes e superiores possam tirar suas dúvidas quanto ao problema. O treinamento de gerentes e chefes para monitorar e identificar as primeiras identificações do conflito, prevenindo o horror que essas condutas provocam na empresa. A empresa pode organizar encontros pelo menos uma vez por mês com todos os funcionários, onde os participantes possam difundir idéias na adoção de medidas, incentivando as boas relações de trabalho e o gerenciamento eficaz das equipes. É importante que essas reuniões sejam abertas para os debates, para a discussão de como está o andamento do trabalho. Nessa etapa, considerada a primeira, a comunicação e o debate em torno das enfermidades laborais do assédio e da prevenção, é fundamental para que todos possam conhecer sobre o tema. Profissionais bem vindos são os pedagogos e os psicólogos que podem ser funcionários da empresa, ou externos.

\footnotetext{
${ }^{264}$ Serviços especializados vistos com detalhes no item 1.4 do capitulo I desse trabalho.
} 
Na comunicação e difusão sobre o tema das enfermidades laborais e das condutas de assédio, é muito importante criar uma cultura de informação por parte da empresa a respeito dos Direitos Humanos dos trabalhadores, reforçando a difusão do Código de Ética da empresa e dos Documentos e/ou iniciativas internacionais de proteção ao trabalhador. Se a empresa não for signatária dos Documentos e/ou iniciativas, colocar em pauta o tema, poderá alertar para a necessidade de fazê-lo.

Outra medida não menos importante é criar dentro da empresa (empresas médias e pequenas) ouvidorias internas, já que nas grandes empresas geralmente existem centrais de denúncias e reclamações. As vítimas da violência psicológica no trabalho geralmente hesitam em falar, nesse caso, deve contar com a ajuda de pessoas que não estão presentes na relação de trabalho e que não fazem parte do seu dia a dia na empresa. As denúncias podem ser feitas por correio eletrônico, telefone ou pessoalmente garantindo o sigilo e anonimato. Mesmo porque, devemos lembrar que muitas vezes, a própria vítima não leva ao conhecimento da empresa o fato de ter sofrido o assédio ou a violência, e, por isso, os profissionais da ouvidoria devem se comprometer que, ao relatarem as ocorrências, serão tomadas medidas justas e eficazes para coibir e reprimir a conduta. Se isso ocorrer, podemos dizer que dentro de determinadas empresas, os casos diminuiriam significativamente. A partir daí, e confirmado a ocorrência dos fatos, o profissional comunica a empresa para que ela tome as providências necessárias. Nessa etapa, a participação de uma equipe multidisciplinar é obrigatória, principalmente com profissionais ligados à psicologia ou à psicosociologia.

O relaxamento e a ginástica laboral no trabalho é uma medida eficaz para que os funcionários possam relaxar antes, ou durante a atividade, pelo menos, duas 
ou três vezes na semana. A prática voluntária da ginástica laboral proporciona ganhos psicológicos, como o favorecimento na mudança da rotina de trabalho, melhorando a capacidade de concentração, favorecendo o contato pessoal, promovendo a integração com os colegas. Os ganhos fisiológicos são vários, como o aumento da circulação sanguínea, a melhora da postura, a mobilidade, a tensão muscular, a melhora da condição e do estado de saúde em geral, diminui o risco de acidentes de trabalho, reduz a fadiga da jornada de trabalho e previne a ler/dort ${ }^{265}$.

Nesse sentido, a empresa pode contratar um especialista em ergonomia para realizar uma avaliação do ambiente de trabalho. Esse especialista visa buscar a adaptação entre o trabalhador e o meio ambiente laboral. Sua ação é de caráter multidisciplinar e contribui para o planejamento, projeto e a avaliação das tarefas e ambientes para que se tornem compatíveis e adaptáveis com às necessidades e limitações das pessoas, como por exemplo: a avaliação do conforto visual, da postura, da iluminação, da cadeira e dos objetos que fazem parte do ambiente de trabalho, das cores, da temperatura, da acústica e da humanização do ambiente, colocando, por exemplo, plantas, quadros ou música ${ }^{266}$.

Pode-se dizer que, quanto mais adaptado for o ambiente ao trabalhador, maiores serão os níveis de eficácia, eficiência e satisfação alcançados por ele durante a jornada de trabalho. Com um ambiente compatível com suas características, ele

\footnotetext{
${ }^{265}$ LER e DORT são as siglas para Lesões por Esforços Repetitivos e Distúrbios Osteo-musculares relacionados ao trabalho, são doenças caracterizadas pelo desgaste de estruturas do sistema músculoesquelético que atingem várias categorias profissionais. Diferentemente do que ocorre com doenças não ocupacionais, as doenças relacionadas ao trabalho têm implicações legais que atingem a vida dos pacientes. O seu reconhecimento é regido por normas e legislações específicas a fim de garantir a saúde e os direitos dos trabalhadores. Geralmente os sintomas são de evolução insidiosa até serem claramente percebidos. Com frequência, são desencadeados ou agravados após períodos de maior quantidade de trabalho ou jornadas prolongadas e em geral, o trabalhador busca formas de manter o desenvolvimento de seu trabalho, mesmo que à custa da dor. A diminuição da capacidade física passa a ser percebida no trabalho e fora dele, nas atividades cotidianas. Fonte: http://www.bancodesaude.com.br/ler-dort/ler-dort. Acesso em 10.03.2010.

${ }^{266}$ Ver mais em Associação Brasileira de Ergonomia:<http://www.abergo.org.br>. Acesso em 09.03.2010.
} 
realizará suas tarefas de maneira mais confortável e em um ambiente saudável, melhorando a qualidade de vida no trabalho. Desse modo, a ergonomia identifica, analisa e reduz os riscos de enfermidades laborais e diminui os riscos psicossociais.

Muitas empresas utilizam, além da ginástica laboral, a meditação com música para o relaxamento, atividades lúdicas e dinâmicas de grupo. A ginástica laboral ou a meditação pode ocorrer duas ou três vezes na semana antes de começar a jornada de trabalho, logo pela manhã. Já as atividades lúdicas ou as dinâmica de grupo podem ser realizadas antes de uma reunião ou evento, de maneira contextualizada. Essas atividades estimulam a criatividade, melhoram o humor, a relação interpessoal e a interação com o grupo, diminuindo o nervosismo e a tensão. E, notadamente, ajudam a amenizar ou a evitar o estresse, melhorando assim a sua saúde mental.

Nesse sentido, partindo do princípio que o indivíduo é um ser social e que a coexistência é a estrutura das relações humanas, raras vezes paramos para observar o que está acontecendo com as pessoas com quem trabalhamos e dificilmente analisamos o nosso comportamento grupal. Inconscientemente, talvez nossa conduta nem sempre atenda as exigências e observações dos outros, podendo criar uma situação constrangedora e conflitante. Por isso, essas atividades na empresa colaboram no sentido de aparar arestas, conscientizar os indivíduos, tornando-os melhores observadores, aprimorando assim, a relação humana num ambiente grupal ${ }^{267}$.

\footnotetext{
${ }^{267}$ FRITZEN, Silvino Jose. Exercícios Práticos de Dinâmica de Grupo. 32ª edição, V.01, Rio de Janeiro: Vozes, 2000, (p.8). O autor diz que "exercicios ou dinâmicas de grupo melhoram a relação com diretores, chefes, gerentes, líderes em geral, com os subordinados, colegas e superiores hierárquicos. É preciso criar um clima de relações verdadeiramente humanas do indivíduo com o grupo, do grupo com o indivíduo, dos indivíduos entre si, do grupo com os outros grupos, do chefe com o grupo ou com o indivíduo do grupo, o indivíduo do grupo com o chefe ou líder, do indivíduo com o chefe ou líder e do chefe ou líder com o indivíduo".
} 
Algumas empresas ainda tem programas de combate ao fumo, combate ao alcoolismo e a obesidade. Outras, contam com uma iniciativa bem criativa que é a "sala do descanso", onde o funcionário pode usufruir de um espaço dentro da empresa com música ambiente, vídeos e móveis confortáveis para que possa relaxar depois das refeições ou durante os intervalos de trabalho.

O setor encarregado pelas atividades mencionadas é o setor de Recursos Humanos ou setor de Gestão de Pessoas, que deve contar com uma equipe de profissionais multidisciplinar, fisioterapeutas, psicólogos e pedagogos. Esse tipo de iniciativa é mais comum em empresas de grande e médio porte. Entretanto, as empresas menores podem utilizar as atividades mencionadas com os próprios funcionários ou, contratar um profissional que realize, pelo menos uma vez por semana, a ginástica laboral. Paralelo a isso, as reuniões e os grupos de discussão a respeito do assédio das enfermidades laborais no trabalho não podem deixar de existir.

Percebemos que, não se pode mudar a realidade com a mesma rapidez com que se concebe uma mudança. São as ações continuadas e sucessivamente realizadas, que vão construindo no tempo, a mudança maior. Assim, uma prática empresarial responsável, é aquela que realiza avaliações periódicas e adota iniciativas como estas, a partir de ações e estratégias simples, mas orgânicas e com direção bem clara. É certo que, a prevenção e as ações positivas, reduzem de forma significativa qualquer tipo de assédio, enfermidades e violência no trabalho, melhorando o ambiente laboral e reduzindo o clima de terror e medo que ainda fazem parte da vida de muitos empregados.

Por fim, esperamos que as empresas adotem medidas que previnam a ocorrência de infortúnios laborais, e que não se resumam em aplicar medidas 
repressivas. É preciso que elas se importem em realizar esforços positivos aos empregadores que cumprem seu papel social e mantém boas condições no trabalho, respeitando os direitos fundamentais e a dignidade do trabalhador.

\subsection{O Papel dos Sindicatos e dos Órgãos de Proteção ao}

\section{Trabalhador}

No âmbito internacional, a Convenção $n^{\circ} 87$ da OIT garante a liberdade sindical diante dos poderes públicos e a Convenção n ${ }^{\circ} 98$ trata da proteção do direito de sindicalização e de negociação coletiva, dispondo em seu artigo $4^{\circ}$ que "as medidas apropriadas às condições nacionais serão tomadas, se necessário, para estimular e promover o pleno desenvolvimento e utilização de mecanismos de negociação voluntária entre empregadores ou organizações de empregadores e organizações de trabalhadores, com o objetivo de regular, mediante acordos coletivos, termos e condições de emprego."

Essa Convenção tem como objetivo proteger os direitos dos trabalhadores em relação aos empregadores. Protegê-los contra qualquer discriminação voltada para a restrição da liberdade sindical, em relação ao seu emprego, sendo proibido ao empregador condicionar o emprego a não participação ou filiação do trabalhador a um sindicato ou demiti-lo por isso (art. $1^{\circ}$ ). A convenção também impulsiona a negociação coletiva como meio para a resolução de conflitos entre empregados e empregadores. O complemento do tema vem com a Convenção n. 154 de 1981, que incentiva a negociação coletiva em todos os setores ou ramos de atividade.

A negociação coletiva é uma técnica de proteção à pessoa do trabalhador que estabelece convenções de trabalho, regulando, pacificamente, os interesses dos 
trabalhadores e empregadores, com o ponto em comum de que, tanto a intervenção do Estado como o exercício da autonomia privada coletiva através da negociação coletiva, visam compensar a inferioridade econômica do trabalhador em relação ao empregador, com o restabelecimento do equilíbrio econômico entre as partes pelo entendimento e por disposições favoráveis a ambas as partes ${ }^{268}$. OLIVEIRA ${ }^{269}$ acrescenta que " $L a$ negociación clectiva desempeña um importante papel en el ámbito de um Estado Social y Democrático de Derecho que consiste en fomentar el pluralismo político en las relaciones laborales, a fin de establecer um mayor grado de igualdad entre las partes que firman um contrato de trabajo."

Nesse processo, os trabalhadores são representados pelos sindicatos de classe. No Brasil, fundada em 1983, a Central Única dos Trabalhadores (CUT) é uma Organização sindical de caráter classista, autônoma e democrática, com o objetivo defender os interesses da classe trabalhadora, organizar, representar sindicalmente os interesses dos trabalhadores do setor público e privado, ativos e inativos. Segundo a CUT ela se consolida como a maior central sindical do Brasil, da América Latina e a $5^{\mathrm{a}}$ maior do mundo, com 3.299 entidades filiadas e milhões de trabalhadores associados. A CUT defende a liberdade de autonomia sindical com o compromisso de que os trabalhadores têm o direito de decidir livremente sobre suas formas de organização, filiação e sustentação financeira, com tal independência frente ao Estado, ao governo, aos partidos políticos ou quaisquer organismos de caráter programático ou institucional $^{270}$.

A estrutura da CUT se organiza em dois níveis: a organização horizontal que, além da estrutura nacional, demonstra que ela está presente em cada estado da

\footnotetext{
${ }^{268}$ ALKIMIN. Maria Aparecida. Violência na Relação de trabalho (...). Op. Cit. Nota 33, (p.161).

${ }^{269}$ OLIVEIRA, Flávia. El Acoso Laboral. Op. Cit. Nota 189 (p.403).

${ }^{270}$ Fonte: <http://www.cut.org.br/>. Acesso em 14.03.2010.
} 
federação, com as CUTs estaduais. No sentido vertical, está organizada e representada com as organizações de base e as entidades sindicais por ramo de atividade econômica, que compreendem os Sindicatos, as Federações e as Confederações ${ }^{271}$. As Federações atuam, em regra, no território de um estado federado da República. Havendo uma Federação estadual, nada obsta que exista uma Federação interestadual para os demais estados, ou até, uma Federação nacional. Porém, se tais ocorrerem, a Federação nacional não prejudicará a Federação estadual, pois a lei privilegia estas, por serem a sua natural representatividade. As Confederações situam-se no "terceiro degrau" da Organização sindical, sendo sua esfera de atuação nacional. Suas funções básicas são de coordenação das Federações e sindicatos do seu setor ${ }^{272}$.

Sendo assim, a Federação e a Confederação não podem atuar diretamente na Negociação coletiva, de acordo com a legislação vigente, essa competência é dos sindicatos, pois, eles se configuram como associações de base ou de primeiro grau.

A estrutura da Central Sindical também é integrada pelas comissões sobre a Amazônia, Meio Ambiente e Combate à Discriminação Racial e Coletivos de Saúde, Pessoas com Deficiência Física e Juventude. Além dessas comissões existem os organismos para o desenvolvimento de políticas específicas como é o caso do Instituto do Observatório Social, que é uma Organização que analisa e pesquisa o comportamento sócio-trabalhista de empresas multinacionais, nacionais e estatais em relação aos direitos fundamentais dos trabalhadores brasileiros, baseada nos princípios da OIT e, realizando estudos e pesquisas a respeito. O Observatório Social já foi citado nesse trabalho onde discutimos o tema da Responsabilidade Social Empresarial.

\footnotetext{
${ }^{271}$ Como por exemplo o Sindicato dos Bancários, a Confederação Nacional dos Trabalhadores na Industria ou a Federação das Empresas de Transportes Rodoviários do Sul e Centro Oeste do Brasil. Portanto, a maior unidade representativa na organização sindical no Brasil é a central sindical.

${ }^{272}$ SILVA, Rodrigo Alves. Organização Sindical Brasileira. Jus Navigandi, Teresina, ano 7, n. 63, mar/2003. Disponível em:<http://jus2.uol.com.br/doutrina/texto.asp?id=3829>. Acesso em 14.03.2010.
} 
Na Espanha a Unión General de Trabajadores (UGT) nasceu em 1888 a partir do primeiro Congresso Nacional de Obreiros. Desde a sua legalização como Organização sindical em 1977, a UGT está estruturada como uma organização de caráter confederal, integrada por uniões territoriais, federações e uniões estatais. Dispõe de vários órgãos confederados eleitos pelo Congresso Confederal e encarregados de aplicar as políticas do sindicato, velando pelo correto funcionamento da Organização. A UGT se define como "una institución eminentemente de trabajadores, organizados por grupos afines de oficios y profesiones liberales que, para mantenerse en sólida conexión, respeta la más amplia libertad de pensamiento y táctica de sus componentes siempre que estos tiendan a la transformación de la sociedad, para establecerla sobre bases de justicia social, de igualdad y de solidaridad ${ }^{273}$,".

Outro sindicato importante na Espanha é a Confederación Sindical de Comissões Obreras (CC.OO) que se estrutura em federações, segundo as atividades ou setor que pertencem a empresa e uniões, segundo o território onde se localiza o centro de trabalho. Esse sindicato conta com um importante instituto, o ISTAS ${ }^{274}$, que promove, através de informes, estudos e guias, a formação e informação sobre a saúde laboral do trabalhador.

Alguns acordos para a negociação coletiva na Espanha assinados pela CC.OO, UGT, CEOCE ${ }^{275}$ e CEPYME $^{276}$ estabelecem critérios, orientações e recomendações sobre temas como a igualdade de tratamento e oportunidades entre homens e mulheres, segurança e saúde no trabalho, assédio e violência no lugar de

\footnotetext{
${ }^{273}$ Fonte: <http://www.ugt.es/index1.htm>. Acesso em 16.03.2010.

${ }^{274}$ ISTAS. Instituto Sindical de Trabajo, Ambiente y Salud. No item anterior desse trabalho, discorremos sobre o Método ISTAS, configurando uma das ações preventivas pra inibir o assédio e a violência no trabalho. Op. Cit. Nota 61.

${ }^{275}$ Confederación Española de la Pequeña y Mediana Empresa.

${ }^{276}$ Confederación Española de Organizaciones Empresariales.
} 
trabalho, como é o caso do Acuerdo Interconfederal para la negociación colectiva $2007^{277}$, prorrogado para valer também no ano de 2008.

No Brasil, algumas entidades, como é o Sindicato dos Bancários, por exemplo, já lançaram ações em forma de Campanhas para denunciar, segundo eles, o inimigo nem sempre visível, mas sempre constante na categoria - o assédio moral. Geralmente essas mobilizações focam-se na conscientização sobre o assédio e a violência no trabalho. Proporcionam encontros onde são discutidas medidas para combater a conduta, esclarecem dúvidas e estimulam a denúncia. Cartilhas temáticas são confeccionadas e uma série de manifestações e ações de protesto são organizadas.

Nesse sentido, tivemos a oportunidade de entrevistar um dos diretores executivos do Sindicato dos Bancários de Pernambuco sobre o assédio e a violência no ambiente de trabalho e as medidas preventivas realizadas pela entidade ${ }^{278}$. Ele nos disse que as medidas de prevenção até agora implementadas pelo sindicato, tem gerado resultados satisfatórios, porque em primeiro lugar e mais importante é sem dúvida a quantidade de trabalhadores do ramo financeiro que passaram a conhecer os conceitos de assédio moral através do material de divulgação sobre o assédio e a violência no ambiente de trabalho. Além dos conceitos, entenderam como se prevenir e combater essa prática, seja apoiando a vítima ou denunciando o assediador, e que a partir disso, os dirigentes sindicais já podem tratar os casos que chegam até a entidade. O diretor executivo acrescenta ainda, que pelas medidas implantadas, o sindicato obteve uma

\footnotetext{
${ }^{277}$ BOE número 12 de 14.01.2008, páginas 2534 a 2540.

${ }^{278}$ Tivemos a oportunidade de conhecer um dos diretores executivos desse Sindicato em uma Assembléia realizada sobre assédio moral. Enviamos então algumas questões por e-mail, com perguntas a respeito das iniciativas e das ações preventivas realizadas pelo sindicato dos bancários em relação a violência e o assédio no ambiente laboral e o que está sendo feito pela entidade diante de tantas denúncias, em especial pela categoria bancária no país.
} 
conquista que foi a de inserir na Convenção Coletiva de Trabalho ${ }^{279}$ celebrada entre banqueiros e trabalhadores em bancos, cláusulas que estabelecem dispositivos e comissões bipartites permanentes para acompanhamento de denúncias de casos de assédio. Disse ainda, que na última negociação com o Banco do Brasil o assédio e a violência no ambiente laboral tornou-se fato e isso fez com que a empresa, editasse e distribuísse para os funcionários uma cartilha ilustrativa sobre o assédio moral e a visão que os bancos tem sobre o tema.

Quando perguntamos se o Sindicato dos Bancários de Pernambuco tem recebido denúncias de assédio e violência no trabalho, o dirigente disse que sim, e que grande parte dessas denúncias deve-se ao trabalho de conscientização sobre o assédio moral que a entidade vem realizando desde 2004 nas agências, com a palavra de ordem: “Assédio Moral é ilegal e imoral, você não pode ser cúmplice: Denuncie!"280. Salienta ainda que alguns casos sobre assédio moral, tornaram-se estatísticas oficiais de acidentes de trabalho e foram informados ao Ministério da Previdência e que, o segundo caso oficial de acidente de trabalho por assédio moral no país e o primeiro na categoria, foi informado pelo sindicato dos Bancários de Pernambuco. Finaliza dizendo que notadamente, nos anos de 2009 e no início de 2010, foi constatado vários casos de assédio que tornaram-se acidentes de trabalho, em bancos privados.

\footnotetext{
${ }^{279}$ Convenção Coletiva de Trabalho é um instrumento normativo pactuado entre sindicatos representantes de empregadores e empregados. Ela cria uma lei entre as partes, que devem ser respeitadas durante sua vigência. Ressalta-se que suas cláusulas não podem ferir direitos previstos na legislação, sob pena de nulidade. Segundo RUSSOMANO, em sua obra: Princípios Gerais de Direito Sindical. $2^{\mathrm{a}}$ edição, Rio de Janeiro: Forense, 2002, (p.150): "a convenção coletiva de trabalho é o convênio entre o sindicato operário e o sindicato patronal correspondente ou empresas individualmente consideradas, tendo por objeto principal a estipulação de normas a serem respeitadas através dos contratos individuais de trabalho e por objeto secundário a criação de direitos e obrigações assumidas pelos convenentes a título próprio."

${ }^{280}$ Tema da Cartilha distribuída pelo Sindicato, já citada nesse trabalho. A cartilha apresenta histórias em quadrinhos sobre casos verídicos de assédio moral na categoria bancária, com autorização das vítimas. Interessante dizer que o Sindicato ministra palestras em Universidades, escolas e principalmente nas agências bancárias como forma de conscientizar também a sociedade sobre a conduta de assédio no ambiente de trabalho.
} 
Nesse sentido, o sindicato é um órgão muito importante na luta contra a violência e o terror psicológico no trabalho. Através da utilização do marketing social, como material de divulgação, cartilhas, campanhas, frases de impacto, web sites, grupo de discussão e seminários sobre o assédio, as entidades contribuem para que as informações a respeito do tema, cheguem ao alcance de todos, inclusive da sociedade, conscientizando-a contra a conduta do assédio no trabalho. Nesse sentido, ROJAS RIVERO $^{281}$, enfatiza:

Los sindicatos mayoritarios vienen proponiendo desde hace un tiempo que se preste una atención a los riesgos psicosociales por parte de los servicios de prevención, así como que se realicen campañas permanentes de sensibilización. Este tipo de obligaciones debe introducirse en la negociación colectiva como medio eficaz de prevención de los mismos.

Entretanto, nessas ações, não são mencionados o assédio sexual, o assédio por razão de sexo ou, tampouco, as enfermidades laborais como o estresse e o burnout. Fica uma enorme lacuna em relação a saúde do trabalhador e os riscos psicossociais no ambiente de trabalho. Portanto, além dessas medidas, é importante que os órgãos de proteção dos trabalhadores realizem cursos de formação para seus dirigentes sindicais na área de segurança e saúde do trabalho e meio ambiente, fornecendo dados sobre os riscos psicossociais que o trabalhador está sujeito no ambiente laboral, formulando políticas de prevenção e de intervenção através de ação sindical. Essas ações devem ter como objetivo a conscientização ampla sobre as questões relacionadas com o assédio moral, o assédio sexual, o assédio por razão de sexo e as enfermidades laborais, promovendo a melhoria das condições de trabalho e de saúde dos trabalhadores.

\footnotetext{
${ }^{281}$ ROJAS RIVERO, Gloria P. Prevención de los Riesgos Psicosociales en el Ámbito (...). Op. Cit. Nota 67, (p.21).
} 
De acordo com o Instituto Observatório Social, os sindicatos devem promover uma "estratégia sindical" e o primeiro passo é a familiarização e a atualização nas questões e tendências atuais, conhecer as principais referências para os trabalhadores como a Declaração dos Direitos Fundamentais no Trabalho e a Declaração das Multinacionais da OIT, as estratégias do sindicalismo internacional da CIOSL sobre essa temática e as Diretrizes da OCDE para as Empresas Multinacionais. Identificar atores nacionais e internacionais que possam fortalecer a promoção dos seus interesses, conhecer experiências nacionais e internacionais de outros sindicatos e entidades da sociedade civil. Além disso os sindicatos devem identificar as políticas mais relevantes sobre responsabilidade social das empresas por meio de seus pronunciamentos públicos, como os códigos de conduta, balanços sociais, filiação e associações empresariais de Responsabilidade Social Empresarial. O Instituto acrescenta ainda que o outro passo importante da estratégia sindical é o monitoramento e a divulgação da situação encontrada nas empresas, para isso os sindicatos podem comparar as condições de trabalho entre diferentes unidades da empresa, sustentar denúncias e violações dos direitos dos trabalhadores perante organismos nacionais e internacionais. A participação nos espaços de debate, também é importante, assim como criar alianças com entidades da sociedade civil, como as associações de bairro, as ONGs, os fundos de pensão, as empresas fornecedoras de produtos e serviços e o poder público. E no que refere a perspectiva internacional, os sindicatos devem conhecer as principais normas internacionais existentes (OIT e OCDE) e seus mecanismos de acompanhamento e denúncia ${ }^{282}$.

Nesse sentido, não há dúvida que o papel das entidades sindicais é fundamental na prevenção, redução e/ou eliminação dos riscos no ambiente do trabalho

\footnotetext{
${ }^{282}$ Op. Cit. Nota 18, (p.119).
} 
e toda a pessoa que exerce atividade remunerada tem o direito à proteção da sua saúde e o direito à segurança no trabalho. Acreditamos que, é através das ações citadas acima, dos Convênios, dos Acordos e da Negociação coletiva, que os sindicatos podem reivindicar melhorias nas condições de trabalho, a respeito da violência, do assédio e das enfermidades laborais, com a inserção de cláusulas voltadas para a proteção dos Direitos Humanos e fundamentais dos trabalhadores. 


\section{CONSIDERAÇÕES FINAIS}

Em virtude dos fatos mencionados, entendemos que o assédio moral, o assédio sexual e o assédio por razão de sexo, precisam ser estudados nas suas mais variadas formas e de maneira preventiva. É importante considerar diversos fatores ao analisar cada uma dessas atitudes, pois, as ações não ocorrem fora de um contexto. Em especial no contexto laboral, devem ser criadas políticas de gestão e de administração eficazes e que considerem entre outras coisas a definição do que é assédio no ambiente de trabalho e como evitá-lo.

As ações da administração nas empresas devem envolver a comunicação clara e objetiva aos funcionários e as partes interessadas dessas políticas. Também se aconselha a criação de um setor especializado em Recursos Humanos ou de Gestão de Pessoas capaz de intervir, sempre que necessário, realizando periodicamente avaliações de riscos e utilizando ferramentas adequadas. Dessa forma a Avaliação em matéria de Direitos Humanos nas empresas é algo novo, por isso é um desafio. Neste sentido a empresa deve ter em sua estratégia de gestão o respeito as normas internacionais de Direitos Humanos e desenhar empresas socialmente responsáveis.

Além disso, os Estados tem a obrigação de promover e proteger os Direitos Humanos consagrados na legislação internacional e nacional, em particular assegurando com que as empresas cumpram com esses direitos dentro do ramo de suas atividades, assegurando que essas atividades não contribuam direta ou indiretamente no sentido de causar prejuízos aos seres humanos. As empresas devem tomar conhecimento a respeito dos Direitos humanos e sobre as consequências se esses forem violados. Percebemos a 
importância da empresa adotar uma política sobre Direitos Humanos, atentando para documentos internacionais consagrados como a Declaração Universal dos Direitos Humanos de 1948, As Diretrizes para as Empresas Multinacionais da OCDE, A Declaração Tripartite de Princípios sobre Empresas Multinacionais da OIT, O Pacto Global e as Normas de Direitos Humanos para as Empresas das Nações Unidas e outras iniciativas da sociedade civil como vimos no decorrer do trabalho. Por outro lado, os Sindicatos devem atuar como elemento principal na difusão a respeito da violência e do assédio no ambiente de trabalho, utilizando a negociação coletiva e os acordos entre empregados e empregadores, além das ferramentas e mecanismos de acompanhamento e denúncia contra essa forma de conduta.

Do que foi exposto, podemos considerar que o direito a um meio ambiente seguro e saudável é um direito fundamental do trabalhador, pois, garante-lhe a vida e a saúde que são necessárias a sua própria sobrevivência e da sua família. A proteção aos direitos fundamentais do trabalhador deve acompanhar a evolução e as necessidades atuais do mercado laboral, na medida em que o trabalhador fica exposto, cada vez mais, a novos riscos, causando-lhe enfermidades como o estresse, e o burnout. Neste sentido as ações preventivas para inibir o assédio, a violência nas empresas se torna o eixo central para proteção dos Direitos Humanos do trabalhador.

Nossa intenção é contribuir para o debate em torno do tema, fazendo com que essas questões sejam incluídas nas pautas de administração e gestão empresariais e, em especial, no setor bancário, onde as mais variadas formas de assédio encontram-se presentes no dia a dia. 


\title{
REFERÊNCIAS BIBLIOGRÁFICAS
}

\author{
Legislação Brasileira
}

BRASIL. Constituição Federal Brasileira. São Paulo: Saraiva, 2007;

Código Civil. Lei $\mathrm{n}^{\mathrm{o}}$ 10.406/2002. Disponível em: <http://www.planalto.gov.br>. Acesso em 28.11.2009;

Código de Processo Civil. Lei $\mathrm{n}^{\circ}$ 5.869/73. Disponível em: <http://www.planalto.gov.br>. 30.11.2009;

Código Penal. Lei no 2848/1940. Disponível em:<http://www.planalto.gov.br>. Acesso em 02.12.2009;

Consolidação das Leis do Trabalho. Decreto lei $n^{\circ} 5.452$ de $1^{\circ}$ de maio de 1943. Disponível em:<http://www.mte.gov.br>. Acesso em 21.10.2009;

Dispõe sobre os Planos de Benefícios da Previdência Social. Lei $n^{\circ}$ 8.213/91. Disponível em: < http://www.planalto.gov.br>. Acesso em 01.02.2010;

Dispõe sobre a reestruturação da Carreira Auditoria do Tesouro Nacional, sobre a organização da Carreira Auditoria-Fiscal da Previdência Social e da Carreira Auditoria-Fiscal do Trabalho, e dá outras providências. Lei n ${ }^{\circ}$ 10.593/2002. Disponível em:<http://www.planalto.gov.br>. Acesso em 23.10.2009;

Estatuto da Criança e do Adolescente. Lei $\mathrm{n}^{\mathrm{o}}$ 8.069/90. Disponível em: <http://www.planalto.gov.br>. Acesso em 01.02.2010; 


\section{Legislação Espanhola}

Constitución Espanhola de 1978. Publicada no BOE nº 311 de 21.12.1978;

Directiva 2000/78/CE de 27 de noviembre de 2000. Relativa ao establecimiento de um marco general para la igualdad de trato en el empleo y la ocupación. Publicado no Diário Oficial de las Comunidades Europeas L303 de 21.12.2000;

Directiva 76/207/CEE de 9 de febrero de 1976. Relativa a la aplicación del principio de igualdad de trato entre hombres y mujeres en lo que se refiere al acceso al empleo, a la formación y a la promoción profesionales, y a las condiciones de trabajo. Publicada no BOE no 39 de 14.02.1976;

Directiva Marco 89/391. Relativa a la mejora de la protección de la salud y la seguridad en el trabajo. Publicada no Diário Oficial L 183 de 29.06.1989;

Diretiva 2000/43/CE de 29 de junio de 2000. Relativa a la aplicación del principio de igualdad de trato de las personas independientemente de su origen racial o étnico. Publicado no Diário Oficial de las Comunidades Europeas L180 de 19.07.2000;

Estatuto de los Trabajadores. Texto Refundido de La Ley del Estatuto de los Trabajadores. Real Decreto Legislativo 1/1995 de 24 de marzo. Actualizada a la fecha de 27 de marzo de 2007. Disponível em: <http://www.ugt.es>;

Ley 14/1986. Ley General de Sanidad (LGS). Lei publicada no BOE no 102 de 29.04.1986. Acesso em 25.10.2009;

Ley 31/1995. Prevención de Riesgos Laborales (LPRL). Publicada no BOE nº 269 de 10.11.1995; 
Ley sobre Infracciones y Sanciones en el Orden Social (LISOS). Real Decreto Legislativo 5/2000 de 04 de agosto. Disponível em: http://www.ugt.es>Acesso em: 30.12.2009;

Ley Orgánica $n^{\circ}$ 11/1999. De modificación del titulo VIII del Libro II del Codigo Penal. Publicada no BOE $n^{\circ} 104$ de 01.05.1999;

Ley Orgánica: 003/2007 de 22 de março: Para la Igualdad Efectiva de Mujeres y hombres, $\mathrm{BOE}^{\mathrm{o}}$ 71, 23.03.2007;

Recomendação 92/131/CEE de 27 de Novembro de 1991. Relativa à proteção da dignidade da mulher e do homem no trabalho. Publicada no Jornal Oficial $n^{\circ}$ L 049 de 24.02.1992;

Tratado Constitutivo de la Comunidad Europea. Disponível em:<http://europa.eu/legislation_summaries/index_es.htm>. Acesso em 25.10.2009; 


\section{Livros}

Agulló GiMENO, Silvia. La Coherencia Ética en la Gestión de los Recursos Humanos:un factor clave para la forja del ethos corporativo. Tese. Barcelona (ES), 2009. Universitat Ramon Llull. Departamento de Gestíon Empresarial;.

ALEXY, Robert. Teoría de los Derechos Fundamentales. $2^{\mathrm{a}}$ edición, Madrid: Centro de Estudios Políticos y Constitucionales, 2007;

. Derechos Sociales y Ponderación. Madrid: Fundación Coloquio Juridico Europeo, 2007;

ALKIMIN, Maria Aparecida. Violência na Relação de Trabalho e a Proteção à Personalidade do Trabalhador. Curitiba: Juruá, 2008;

Assédio Moral na Relação de Emprego. Curitiba: Juruá, 2006;

ALONSO GARCIA, Ricardo e outros. Economía, Empresa y Trabajo. Madrid: Thomson Civitas, 2003;

ANDERSEN, Arthur. Como mejorar la gestión de las PYMES - Una visión integral del futuro de la pequeña y mediana empresa. Madrid: Expansión, 1991;

ARANGO DURLING, Virginia. Introducción a los Derechos Humanos. República de Panamá: Publipan, 1997;

ARENDT, Hannah. La Condición Humana. Barcelona: Paidós, 2005; 
ASIS, Rafael de; BONDÍA, David; MAZA, Elena. (coordinadores). Los Desafíos de los Derechos Humanos Hoy. Valladolid: Dykinson S.L, 2006;

AUSFELDER, Trude. Mobbing: el acoso moral em el trabajo: prevención, síntomas y soluciones. $2^{\text {a }}$ edición. Barcelona: Oceano Ambar, 2004;

BALLESTER PASTOR, María Amparo. Guía sobre el acoso moral en el trabajo. Guías de Negociación. Junta de Andalucia - Consejería de Empleo. Consejo Andaluz de Relaciones Laborales. Universidad de Valencia, 2006;

BARBANCHO TOVILLAS, Fernando (coordinador). Introducción al derecho del trabajo y la seguridad social. Madrid: Ciencias Juridicas, 2000;

BARDIN, Laurence. Análise de Conteúdos. Lisboa: Edições 70, 1977;

BARRETO, Margarida. Violência, Saúde e Trabalho (uma jornada de humilhações), $2^{\mathrm{a}}$ reimpressão, São Paulo. Editora PUCSP, 2006;

BARBIER, Jean-Marie. Avaliação em Formação. Porto: Afrontamento, 1990;

BARZOTTO, Luciane Cardoso. Direitos Humanos e trabalhadores. Atividade Normativa da Organização Internacional do Trabalho e os Limites do Direito Internacional do Trabalho. Porto Alegre: Livraria do Advogado, 2007;

BAUER, Ruben. Gestão da Mudança - caos e complexidade nas Organizações. São Paulo: Atlas, 1999;

BENAVIDES, F.C. RUIZ FRUTOS y A.M. GARCÍA. Salud laboral: Conceptos y técnicas para la prevención de riesgos laborales. Barcelona, Masson, 1997; 
BOBBIO, Norberto. A Era dos Direitos. $5^{\text {a }}$ edição. Rio de Janeiro: Campus/Elsevier, 2004;

BOBBIO, Norberto. II positivismo giurídico. Torino, G. Giappichelli, 1979,

BOOG, Gustavo e BOOG, Magdalena. Manual de Gestão de Pessoas e Equipes: estratégias e tendências. Vol. I. São Paulo: Gente, 2002;

CABERO MORÁN, Enrique. La Democracia Interna en los Sindicatos. Madrid: Colección Estudios, 1997;

CANÇADO, Antonio Augusto Trindade. A Proteção Internacional dos Direitos Humanos: fundamentos jurídicos e instrumentos básicos. São Paulo: Saraiva, 1991;

O Direito Internacional em um mundo em transformação. São Paulo:

Renovar, 2002;

CANOtIlHO, José Joaquim Gomes. Direito Constitucional e Teoria da Constituição. $9^{a}$ edição. Coimbra: Almedina, 2003;

Estado Constitucional, ecológico e democracia sustentada. In: Estudos de Direito Constitucional em homenagem a José Afonso da Silva. Eros Roberto Grau et al (Coord.). São Paulo: Malheiros, 2003;

O Direito Internacional em um Mundo em Transformação. São Paulo: Renovar, 2002;

CARRILlO SALCEDO, Juan Antonio. Dignidad Frente a Barbarie - La Declaración Universal de Derechos Humanos, cincuenta años después. Madrid: Trotta, 1999; 
CASADEVANTE ROMANI, Carlos Fernández (coordinador). Derecho Internacional de los Derechos Humanos. $3^{\text {a }}$ edición, Madrid: Dilex, 2007;

DIAS SOBRINHO, José. Avaliação da Educação Superior. Petrópolis, RJ: Vozes, 2000;

DÍEZ PICAZO, Luís María. Sistema de Derechos Fundamentales. Madrid: Thomson Civitas, 2003;

DIMENSTEIN, Gilberto. Democracia em Pedaços - Direitos Humanos no Brasil. São Paulo: Cia das Letras, 1996;

DRUCKER, Peter Ferdinand. Administrando em Tempos de Grandes Mudanças. Tradução: Nivaldo Montingelli Jr. São Paulo: Pioneira, 1995;

DWORKIN, Ronald. Uma questão de princípio. São Paulo: Martins Fontes, 2000;

ENCARNACIÓN FERNÁNDEZ. Igualdad y Derechos Humanos. Madrid: Tecnos, 2003;

ESCUDERO MORATALLA, José Francisco y POYATOS i MATAS, Glória. Mobbing: Aanálisis multidisciplinar y estrategia legal. Barcelona: Bosch, 2004;

ESTUDIOS MULTIDISCIPLINARES DE GÉNERO. Centro de Estudios de la Mujer. Las Mujeres en la Constitución Europea. Ediciones Universidad Salamanca, 2005;

ETXEBERRIA, Xabier; MARTÍNEZ NAVARRO, Emilio; TEITELBAUM, Alejandro. Etica y Derechos Humanos en la Cooperación Internacional. Bilbao: Universidad de Deusto: Instituto de Derechos Humanos, Cuaderno Deusto de Derechos Humanos, 2002; 
FARIA, Maria de Fátima Bruno de. Gestão de Pessoas. Universidade de Brasília. Centro de Educação à Distância, Brasília (DF), 2006;

FERNÁNDEZ PEREIRA, Juan Pablo. La Seguridad Humana - Un Derecho Emergente. Barcelona: Ariel, 2006;

FERREIRA, Aurélio Buarque de Holanda. Novo Aurélio. Século XXI. O Dicionário da Língua Portuguesa. $3^{\text {a }}$ edição, Rio de Janeiro: Editora Nova Fronteira, 1999;

FERREIRA, João Batista. Perdi um jeito de sorrir que eu tinha: violência, assédio moral e servidão voluntária no trabalho. Rio de Janeiro: Sete Letras, 2009;

FREITAS, Lucia Barros. Discriminación Sexista y Otras Formas de Violencia Estructural e Institucional cotra la Mujer. Madrid, 2004. Tese. Universidad Carlos III de Madrid. Instituto de Derechos Humanos Bartolomé de las Casas;

FREITAS, Maria Ester; HELOANI, Roberto; BARRETO, Margarida. Assédio Moral no Trabalho. São Paulo: Cengage, 2008;

FRITZEN, Silvino Jose. Exercícios Práticos de Dinâmica de Grupo. 32a edição, V.01, Rio de Janeiro: Vozes, 2000;

GARCÍA FERNÁNDEZ, Manuel. Manual de Derecho del Trabajo. Barcelona: Ariel, 1990;

GRAU, Eros Roberto. (coord). Estudos de Direito Constitucional em Homenagem a José Afonso da Silva. São Paulo: Malheiros, 2003;

GOMES, Luiz Flávio e PIOVESAN, Flávia. O Sistema Interamericano de Proteção dos Direitos Humanos e o Direito Brasileiro. São Paulo: RT, 2000; 
GONZÁleS DE RIVERA, José Luis. El Maltrato Psicológico. Como defenderse del mobbing y otras formas de acoso. Madrid: Practico Espasa, 2002;

GOÑI SEIN, José Luis. El respeto a la esfera privada del trabajador - um estúdio sobre los limites del poder de control empresarial. Madrid: Civitas, 1988;

GUEDES, Márcia Novaes. Terror Psicológico no Trabalho. 2a edição, São Paulo: LTR, 2004;

HIRIGOYEN, Marie-France. Assédio Moral: a violência perversa do cotidiano. Rio de Janeiro: Beltrand Brasil, 2006;

El Acoso Moral en el Trabajo: distinguir lo verdadero de lo falso. Buenos Aires: Paidós, 2001;

El Acoso Moral. El maltrato psicológico en la vida cotidiana. Barcelona: Paidós, 1999;

Mal-estar no trabalho: redefinindo o assédio moral. $3^{\text {a }}$ edição, Rio de Janeiro: Beltrand Brasil, 2006;

ILLUECA, Haydée. Acoso Sexual: um problema laboral. Panamá. Instituto de la Mujer de la Universidad de Panamá, 2002;

IÑAKI PIÑUEL. Mobbing: manual de autoayuda - claves para reconocer $y$ superar el acoso en el trabajo. Madrid: Santillana Ediciones, 2003;

JIMÉNEZ TELLO, Pilar. Auditoría Universitaria y Calidad. La evaluación como conquista social ante la competencia universitaria global. UDM, USA, 2009; 
JO, Hee Moon. Introdução ao Direito Internacional. $2^{a}$ edição, São Paulo: LTR editora, 2004;

LAFER, Celso. A Reconstrução dos Direitos Humanos - um diálogo com o pensamento de Hannah Arendt. São Paulo: Companhia das Letras, 1998;

LAKATOS, Eva Maria e MARCONI, Marina de Andrade. Fundamentos de Metodologia Científica. 6a edição. São Paulo: Atlas, 2007;

LEMBO, Cláudio. A Pessoa. Seus Direitos. São Paulo: Manole, 2007;

LEYMANN, Heinz. Mobbing: la persécution au travial. Ed. Du Seuil, Paris, 1996;

LUCKESI, Cipriano. Avaliação da Aprendizagem Escolar. São Paulo: Cortez, 2005;

MARMELSTEIN, George. Curso de Direitos Fundamentais. São Paulo: Atlas, 2008;

MARTÍN HERNÁNDEZ, María Luisa. El derecho de los trabajadores a la seguridad y salud en el trabajo. Madrid: Consejo Económico y Social, 2006;

MARTÍN ORTEGA, Olga. Empresas Multinacionales y Derechos Humanos en Derecho Internacional. Barcelona: Bosch Editor, 2008;

MELO, Raimundo Simão de. Direito ambiental do trabalho e a saúde do trabalhador. São Paulo: LTr, 2008;

MELlO, Celso Antonio Bandeira de. Conteúdo Jurídico do Princípio de Igualdade.

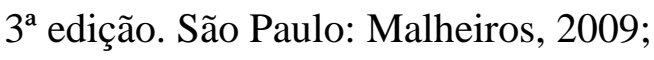

MELlO, Celso D. de Albuquerque. Curso de Direito Internacional Público. 13 edição, Rio de Janeiro: Renovar, 2001; 
OLIVARES ABAJO, Francisco Javier. Mobbing: acoso psicológico en el ámbito laboral. Buenos Aires: Depalma, 2004;

OLIVEIRA, Flávia. El Acoso Laboral. Valencia, 2005. Tese. Departamento de Derecho del Trabajo y de La Seguridad Social. Universitat de Valencia;

PALOMEQUE LÓPEZ, Manuel Carlos; ÁLVAREZ DE LA ROSA, Manuel. Derecho del Trabajo. 15 a edición. Madrid: Editorial Centro de Estudios Ramón Areces S.A, 2007;

Derecho del Trabajo y Razón Crítica. Libro dedicado al profesor Manuel Carlos Palomeque López en su $25^{\circ}$ aniversario como catedrático. Salamanca: Gráfica Verona, 2004;

PÉREZ LUÑO, Antonio. Derechos Humanos. Estado de Derecho y Constitución. 9 ${ }^{a}$ edición. Madrid: Tecnos, 2005;

PEREZ LUÑO, Antonio. Los Derechos Fundamentales. 9ª edición. Madrid: Tecnos, 2007;

PIÑUEL y ZABALA, I. Mobbing: Cómo sobrevivir al acoso psicológico en el trabajo. Santander: Sal Terrae, 2001;

PIOVESAN, Flávia. Temas de Direitos Humanos. São Paulo: Max Limonad, 1988;

RAMOS, Cosete. Excelência na Educação - A escola de qualidade total. Rio de Janeiro: Qualitymark, 1992;

REIS, Germano Glufke. Avaliação 360 Graus. Um Instrumento de Desenvolvimento Gerencial. 2a edição, São Paulo: Atlas, 2007; 
RIBEIRO, Amélia. Pedagogia Empresarial: atuação do pedagogo na empresa. Rio de Janeiro: Wak, 2003;

ROJAS RIVERO, Gloria P. Delimitación, prevención y tutela del acoso laboral. Albacete: Editoral Bomarzo, 2005;

RUIZ OLABUÉNAGA. Metodología de la Investigación Cualitativa. Bilbao: Universidad de Deusto, 1996;

RUSSOMANO, Mozart Victor. Princípios Gerais de Direito Sindical. $2^{\text {a }}$ edição, Rio de Janeiro: Forense, 2002.

SALINAS DE FRÍAS, Ana. La protección de los Derechos Fundamentales en la Unión Europea. Granada: Comares, 2000;

SASTRE IBARRECHE, Rafael. El Derecho al Trabajo. Madrid: Trotta, 1996;

SILVA, Geraldo Eulálio do Nascimento; ACCIOLY, Hildebrando. Manual de Direito Internacional Público. 15a edição, São Paulo: Saraiva, 2002;

SILVA, Jaqueline Heldt. Assédio Moral nas Relações de Trabalho Frente ao Princípio da Dignidade da Pessoa Humana. Porto Alegre (RS). Trabalho de conclusão de curso apresentado a Pontifícia Universidade Católica do Rio Grande do Sul, 2006;

SILVA, José Afonso. Curso de Direito Constitucional Positivo. 10 edição. São Paulo: Malheiros, 1994;

Direito Ambiental constitucional. São Paulo, Malheiros, 1998; 
SOEST, Van. The Global Crisis of Violence. Common problems, universal causes, shared solutions. Washington, D.C. National Association os Social Workers, 1997;

SOUZA, Perci; SOARES, Francilene. Responsabilidade Socioambiental. Universidade de Brasília, Centro de Educação à Distância. Brasília, 2006,

SOUZA, Vera Lúcia. Gestão de Desempenho: julgamento ou diálogo? Rio de Janeiro: FGV, 2002;

STEPEHN LAW. Filosofia. Rio de Janeiro: Zahar, 2008;

TEITELBAUM, Alejandro; ETXEBERRIA, Xabier; NAVARRO, Emilio. Ética y Derechos Humanos en la Cooperación internacional. Instituto de Derechos Humanos. Cuaderno Deusto de Derechos Humanos, Bilbao, 2002;

TORRES, Ciro; BEZERRA, Isaías; HERNANDES, Tânia (organizadores). Responsabilidade Social das Empresas Multinacionais. Diretrizes da OCDE. Rio de janeiro: CERIS/IBASE, 2004

VAN SOEST. The Global Crisis of Violence. Common problems, universal causes, shared solutions. Washington, D.C. National Association os Social Workers, 1997;

VIANA, Márcio Tulio; RENAULT, Luiz Otávio Linhares et al. (Coords.). Discriminação. São Paulo: LTr, 2000;

WILSON STAFF, Mariblanca; MÉNDEZ ILLUECA, Haydée. Acoso Sexual: un problema laboral. Panamá. Instituto de la Mujer de la Universidad de Panamá, 2002, ZUÑIGA RODRÍGUEZ, Laura. Política Criminal. Madrid: Colex, 2001. 
AHLERT, Alvori. Ética e Direitos Humanos: princípios educacionais para uma sociedade democrática. Nómadas. Revista Crítica de Ciencias Sociales y Jurídicas, 16, 2007.2;

BALLBÉ, Manuel. El futuro del Derecho Administrativo en la Globalización: entre la americanización y la europeización. Revista de Administración Pública. ISSN: 0034-7639, Madrid, n 174, (pp. 215-276), 2007;

BARZOTTO, Luciane Cardoso. Códigos de Conduta, Responsabilidade Empresarial e Direitos Humanos dos Trabalhadores. Revista LTr. Legislação do Trabalho, São Paulo, v. 67, n. 08, (pp. 917-929), 2003;

CABERO MORÁN, Enrique. Igualdad y Relaciones. Algunas reflexiones en el Día Internacional de la Mujer. La igualdad como compromiso. Estudios de género en homenaje a la profesora Ana Díaz Medina. Ediciones Salamanca y los autores. Organizadores: Esther Martínez, Angela Figueruelo, Maria Teresa López de la Vieja, Olga Barrios, Carmen Velayos y Maria Dolores. Salamanca, (p. 85), 2007;

CANTINI, Adriana Hartemink; CANTINI, Juliane Hartemink. Avaliação Institucional: avaliar para repensar a prática. Revista Infocus, ano 02, n ${ }^{\circ} 04$, ISSN 1677-8154, (pp.1-5) Recife, novembro/2005;

Juliane Hartemink. Avaliação Institucional nas Universidades Brasileiras: uma política pública buscando a qualidade do ensino. Revista Enred. Universidade de Salamanca (ES), nº 04, ISSN 1988-5040, 2008; 
FIGUERELLO BURRIEZA, Ángela. Setenta y cinco años de sufragio femenino en España: perspectiva constitucional. La igualdad como compromiso. Estudios de género en homenaje a la profesora Ana Díaz Medina. Ediciones Salamanca y los autores. Organizadores: Esther Martínez, Ángela Figueruelo, Maria Teresa López de la Vieja, Olga Barrios, Carmen Velayos y Maria Dolores. Salamanca, (pp.165-182), 2007;

FRANÇA, Ronaldo. Fome de ar, água e comida. Revista Veja, Edição 2143, ano 42, nº 50, são Paulo, 16 de dez/ (pp. 133-146), 2009;

FREITAS, Maria Ester de. Assédio Moral e Assédio Sexual: faces do poder perverso nas organizações. Revista Administração de Empresas. volume 41, no 02 (pp. 8-19), abril/junho de 2001;

GÓMEZ ALVAREZ, Tomás; GORELLI HERNÁNDEZ, Juan. El acoso moral: perspectivas jurídico laborales. Revista General de Derecho del Trabajo y de la Seguridad Social, ISSN 1696-9626, nº 2003;

HUMENHUK, Hewerstton. O direito à saúde no Brasil e a teoria dos direitos fundamentais. Disponível em: <http://jus2.uol.com.br/doutrina/texto.asp?id=4839>. Acesso em: 27.08. 2009;

JIMÉNEZ TELLO, Pilar. Multiculturalidad y Sociedad del Conocimiento. Perspectiva de género. Auditoria y evaluación como instrumento decisivo para el desarrollo sustentable de los derechos de la mujer en la sociedad del conocimiento. Ed.Comares, 2009;

KAPAZ, Emerson. O que é Responsabilidade Social? Revista Fae Business, nº 9, setembro, (pp.8-10), 2004; 
NOBRE JÚNIOR, Edilson Pereira. O Direito brasileiro e o princípio da dignidade da pessoa humana . Jus Navigandi, Teresina, ano 4, n. 41, maio 2000. Disponível em: <http://jus2.uol.com.br/doutrina/texto.asp?id=161>. Acesso em: 01.07.2009;

OLIVEIRA, Lourival José e TERRIN, Kátia Alessandra Pastori. Assédio Moral no Ambiente de Trabalho: Propostas de Prevenção. Revista do Direito Público. Universidade Estadual de Londrina (PR), ISSN 1980-511X, v 1, s/d;

PAMPLONA FILHO, Rodolfo. Assédio sexual: questões conceituais. Jus Navigandi, Teresina, ano 9, n. 704, 9 jun. 2005. Disponível em: <http://jus2.uol.com.br/doutrina/texto.asp?id=6826>. Acesso em: 30.11.2009;

PIOVESAN, Flávia. Ações Afirmativas no Brasil: desafios e perspectivas. Scielo Brasil. Revista Estudos Feministas. Volume 16, $\mathrm{n}^{\mathrm{o}}$ 03, Florianópolis (SC). Setembro/Dezembro de 2008;

QUINTANA PELLICER, José. El Acoso Sexual en el Trabajo en la Doctrina del Tribunal Constitucional y de los Tribunales del Orden Social de la Jurisdicción. Tribuna Social. Revista de Seguridad Social y Laboral. Valencia, no 222, (pp.40-49), Junio de 2009;

ROJAS RIVERO, Gloria P. Prevención de los riesgos psicossociales en el ámbito de la Administración Pública. Tribuna social. Revista de Seguridad Social y Laboral. Valencia, n ${ }^{\circ}$ 222, (pp.11-24)Junio de 2009;

SILVA, Rodrigo. Organização sindical brasileira. Jus Navigandi, Teresina, ano 07, n. 63, mar/2003, Disponível em: <http://jus2.uol.com.br/doutrina/texto.asp?id=3829>. Acesso em 14.03.2010; 
SOLOMON. Robert, C. A Ética Empresarial. A Companion to Ethics. Universidade do Texas, Austin, 1993. 


\section{Informes}

AMNESTY INTERNATIONAL. The State of the Worlds Human Rights. London, 2008, 405p;

AMNISTÍA INTERNACIONAL. Las Normas de Derechos Humanos de la ONU para Empresas: hacia la responsabilidad legal. Madrid, 2004, 42p;

BANCO DO BRASIL S.A. Gestão de Desempenho Profissional: Você de olho no seu placar. Cartilha auto-instrucional. Brasília, Banco do Brasil, 1998, 20p;

BANCO DO BRASIL S.A . PROFI Universidade Corporativa do Banco do Brasil Sustentabilidade e Futuro. Edição: Versal Multimídia, Brasília (DF), circulação: Junho de 2008, 20p;

COMISIÓN DE LAS COMUNIDADES EUROPEAS. Libro Verde. La responsabilidad social de las empresas: una contribución empresarial al desarrollo sostenible. 2002, 27p;

ESADE. Guía Práctica de Derechos Humanos para Empresas. Maria Prandi, Jose M. Lozano. Escola de Cultura de paz (UAB) / ESADE, septiembre, 2006, 106p;

HUMAN RIGHTS \& BUSINESS. Human Rights Compliance Assessment (HRCA) Evaluación del cumplimiento de los Derechos Humanos - "Quick Check". Danish Institute for Human Rights, Dinamarca, 2006, 64p;

INSTITUTO OBSERVATÓRIO SOCIAL. Responsabilidade Social e Empresarial: perspectivas para a atuação sindical. Florianópolis (SC), 2004, 132p; 
OCDE. Diretrizes. TORRES, Ciro; BEZERRA, Isaías; HERNANDES, Tânia (organizadores). Responsabilidade Social das Empresa Multinacionais. Rio de janeiro: CERIS/IBASE, 2004, 95p;

OFICINA INTERNACIONAL DEL TRABAJO. Las Reglas del Juego. Una Breve Introducción a las Normas Internacionales del Trabajo. Departamento de Normas Internacionales del Trabajo. Ginebra, 2009, 112p;

ONU. Guía del Pacto Global. Una forma práctica para implementar los nueve principios en la gestión empresarial. Oficina del Pacto Global en Argentina. Sistema de Naciones unidas en Argentina, Buenos Aires, 2004, 120p;

ONU. La Seguridad Humana Ahora. Comisión para la Seguridad Humana. Informe final. Multi-Language Services Inc, Nueva York, 2003;

ONU. Libro Azul. La Implantación del Pacto Mundial de Naciones Unidas en las Empresas Españolas. Secretaría del Pacto Mundial de Naciones Unidas en España. Madrid, 2004, 102p;

OIT. Manual de Autoaprendizaje, Acoso sexual, Legislación y Procedimientos de Aplicación. Santiago. Oficina Internacional del Trabajo, 2006, 192p;

OIT. The Labour Principles of the UN Global Compact - A Guide for Business. Geneva, 2008, 49p;

OIT. Uma Aliança Global contra o Trabalho Forçado. Relatório global de seguimento da OIT sobre Princípios e Direitos Fundamentais no Trabalho. (93 ${ }^{\text {a }}$ reunião/Genebra), 2005, 155p; 
UNICEF. Informe. Estado mundial da Infância - excluídos e invisíveis. 2006, 156p. 


\section{Sites Consultados}

Agencia Europea para la Seguridad y la Salud en el Trabajo (OSHA). Disponível em: <http://osha.europa.eu/es/about>. Acesso em 24.10.2009;

Amnistía Internacional. Disponível em:<http://www.es.amnesty.org/es. Acesso em 19.02.2009;

Associação Brasileira de Ergonomia. Disponível em: <http://www.abergo.org.br>. Acesso em 09.03.2010;

Associação Brasileira de Normas Técnicas (ABNT). Disponível em:<http://www.abnt.org.br/>. Acesso em 20.02.2010;

Banco de Desenvolvimento Econômico e Social (BNDES). Disponível em:〈http://www.bndes.gov.br>. Acesso em 20.02.2010;

Banco do Brasil S.A. Disponível em:〈http://www.bb.com.br $\rangle$. Acesso em: 18.12.2009;

Banco Interamericano de Desenvolvimento (BID). Disponível em:<http://www.iadb.org>. Acesso em 20.02.2010;

Boletín Oficial del Estado España- BOE - Disponível em:<http://www.boe.es/>. Acesso em 23.02.2009;

Business for Social Responsability. Disponível em: 〈http://www.bsr.org>. Acesso em 02.03.2010; 
Câmara dos Deputados do Brasil. Disponível em:<http://www2.camara.gov.br>. Acesso em 20.03.2009;

Central Única dos Trabalhadores (CUT). Disponível em: <http://www.cut.org.br/>. Acesso em 14.03.2010;

Club Excelencia en Gestión. Disponível em: <http://www.clubexcelencia.org>. Acesso em 15.06.2010;

Código de Ética Empresarial. Disponível em:<http://eticaempresarial.com.br>. Acesso em 18.12.2009;

Comissão Interna de Prevenção de Acidentes (CIPA). Disponível em:<http://www.cipanet.com.br/index.asp>. Acesso em 23.10.2009;

Confederación Sindical Internacional. Disponível em:<http://www.ituc-csi.org/>. Acesso em 02.01.2010;

Council of Europe. Disponível em:<http://www.coe.int>. Acesso em 17.10.2009;

Cursos de Educação à Distância. Síndrome do Burnout em Professores. Disponível em:<http://cursoschafic.com>. Acesso em 03.12.2009;

Derecho de La Unión Europea. Disponível em:http://www.eur-europe.eu>. Acesso em 26.11.2009;

Diccionário de La Real Academia Española. Disponível em:<http://www.rae.es>. Acesso em 07.12.2009; 
Escola de Cultura de Pau. Disponível em:<http://www.escolapau.uab.cat/>. Acesso em: 05.03.2009;

Fundo das Nações Unidas para a Infância. (UNICEF). Disponível em:<http://www.unicef.org.br/>. Acesso em 20.02.2009;

Global Reporting Initiative. Disponível em: <http://www.globalreporting.org>. Acesso em: 11.02.2010;

Health and Safety Executive (HSE). Disponível em:<http://www.hse.gov.uk/>. Acesso em: 24.10.2009;

Human Rights. Disponível em: <http://www.hrc.org/>. Acesso em 05.03.2009;

Instituto Brasileiro de Análises Sociais e Econômicas (IBASE). Disponível em: <http://www.ibase.org.br/>. Acesso em 18.02.2010;

Instituto Ethos do Brasil. Disponível em:<http://www1.ethos.org.br>. Acesso em 05.02.2009;

Instituto Nacional de Metrologia, Normatização e Qualidade Industrial (Inmetro). Disponível em: <httpp//: www.inmetro.gov.br>. Acesso em: 23.02.2010;

Instituto Nacional de Seguridad e Higiene en el Trabajo. Disponível em: <http://www.insht.es/portal/site/Insht/>. Acesso em 08.12.2009;

Instituto Sindical de Trabajo Ambiente y Salud (ISTAS). Disponível em:<http://www.istas.ccoo.es>. Acesso em: 03.12.2009; 
International Business Leaders Forum. Disponível em: 〈http://www.iblf.org〉. Acesso em: 05.03.2009;

International Finance Corporation. Disponível em: <http://www.ifc.org/Portuguese>. Acesso em: 20.02.2010;

International Organization for Standardization (ISO). Disponível em:<http://www.iso.org/isso > . Acesso em 18.02.2010;

Legislação da União Européia. Disponível em:<http://eur-lex.europa.eu>. Acesso em 26.11.2009;

Ministério da Saúde do Brasil. Rede Interagencial de Informações para a saúde. Disponível em:<http://www.datasus.gov.br/idb>. Acesso em 11.12.2009;

Ministério de Desenvolvimento Social e combate à fome. Disponível em:<http://www.mds.gov.br/suas/>. Acesso em 24.01.2010;

Ministério del Trabajo e Inmigración. Disponível em:〈http://www.mtin.es/itss $>$. Acesso em 01.03.2010;

Ministério do Trabalho e Emprego (MTE). Disponível em:〈http://www.mte.gov.br〉. Acesso em 28.01.2008;

Modelo Europeu de Gestão de Qualidade. Disponível em:<http://www.efqm.org> Acesso em 15.06.2010;

Organização das Nações Unidas (ONU). Disponível em:<http://www.onubrasil.org.br/index.php>. Acesso em 20.02.2009; 
Organização Internacional do Trabalho - OIT. Disponível em: <http://www.ilo.org>. Acesso em 28.01.2009;

Organização para a Cooperação e Desenvolvimento Econômico (OCDE). Disponível em: 〈http:/wwww.ocde.org>. Acesso em 23.02.2009;

Pacto Global (Global Compact). Disponível em:<http://www.pactoglobal.org/>. Acesso em 23.02.2009;

Presidência da República Federativa do Brasil. Disponível em:〈http://www.planalto.gov.br>. Acesso em 28.11.2009;

Programa das Nações Unidas para o Desenvolvimento (PNUD). Disponível em: <http://www.pnud.org.br/pnud/>. Acesso em: 05.02.2009;

Recursos Humanos e Gestão de Pessoas. Disponível em: 〈http://www.rh.com.br>. Acesso em 16.12.2009;

Red Española del Pacto Mundial. Disponível em: <http://www.pactomundial.org/>. Acesso em: 05.02.2009;

Sindicato dos Bancários de Pernambuco. Disponível em:<http://bancariospe.org.br>. Acesso em 20.03.2009;

Social Accountability International. Disponível em:<http://www.sa-intl.org/ >. Acesso em 22.02.2010;

Transparency International. Disponível em:<http://transparency.org>. Acesso em: 20.02.2009; 
Unión General de Trabajadores. Disponível em:〈http://www.ugt.es $>$. Acesso em 05.12.2009. 